UNIVERSIDADE DE SÃO PAULO

ESCOLA DE COMUNICAÇÕES E ARTES

FELIPE FAGLIONI

Instrumentos de sopro de madeira como alegoria retórica na música europeia do século XVIII 


\title{
Instrumentos de sopro de madeira como alegoria retórica na música europeia do século XVIII
}

\author{
Versão Corrigida \\ (versão original disponível na Biblioteca da ECA/USP) \\ Tese apresentada à Escola de Comunicações e Artes \\ da Universidade de São Paulo para a obtenção do \\ título de Doutor em Musicologia.
}

Orientadora: Profa. Dra. Mônica Isabel Lucas

São Paulo

2021 
Autorizo a reprodução e divulgação total ou parcial deste trabalho, por qualquer meio convencional ou eletrônico, para fins de estudo e pesquisa, desde que citada a fonte.

Faglioni, Felipe

Instrumentos de sopro de madeira como alegoria retórica na música europeia do século XVIII / Felipe Faglioni ;

orientadora, Mônica Isabel Lucas. -- São Paulo, 2021.

277 p.: il.

Tese (Doutorado) - Programa de Pós-Graduação em Música -

Escola de Comunicações e Artes / Universidade de são Paulo.

Bibliografia

Versão corrigida

1. Instrumentos de sopro de madeira 2. Século XVIII 3.

Alegoria retórica I. Lucas, Mônica Isabel II. Título.

CDD 21.ed. - 780 
Nome: FAGLIONI, Felipe

Título: Instrumentos de sopro de madeira como alegoria retórica na música europeia do século XVIII

Tese apresentada à Escola de Comunicações e Artes da Universidade de São Paulo para a obtenção do título de Doutor em Musicologia.

Aprovado em:

Banca Examinadora

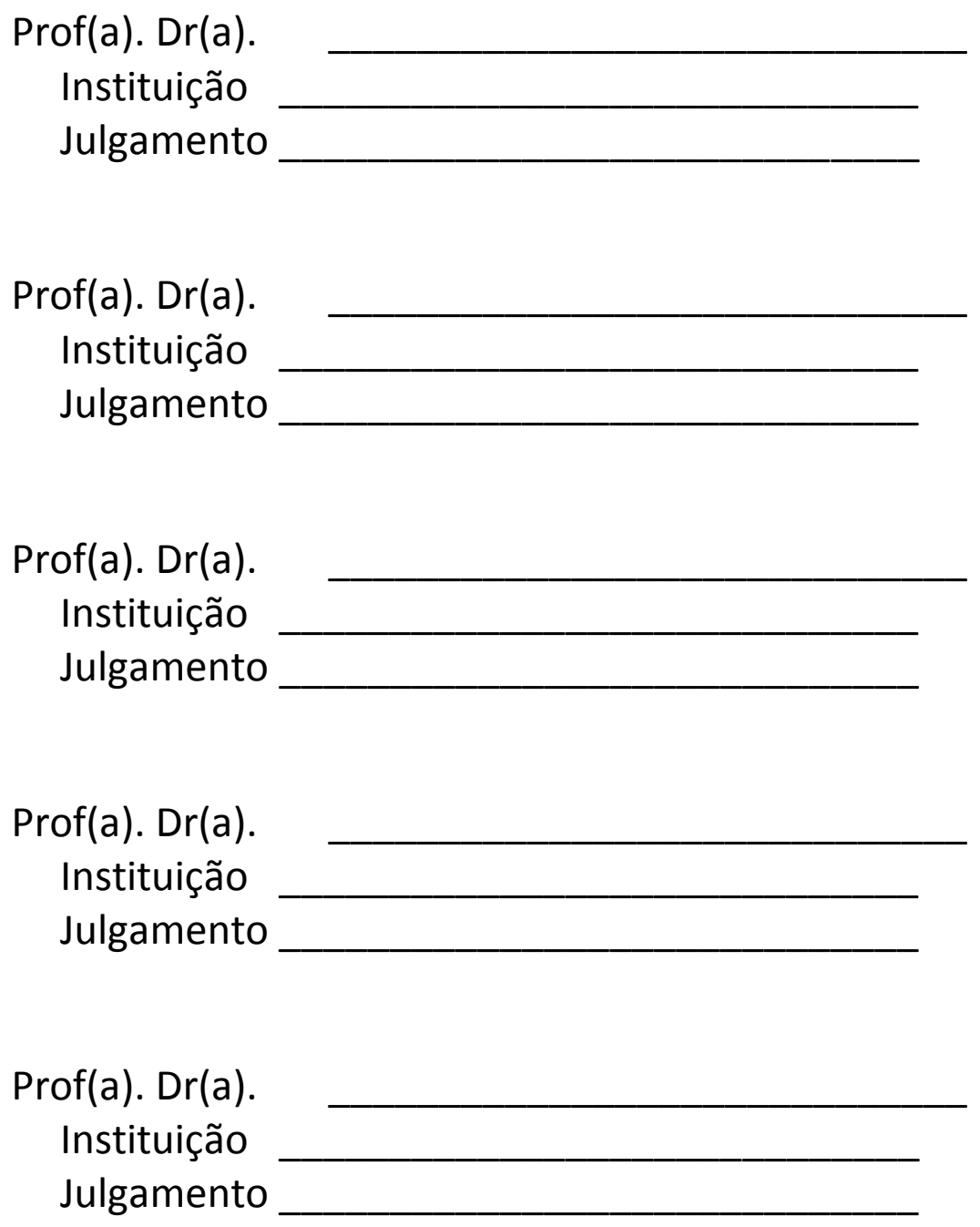


À minha mãe, meu pai e minha irmã, com todo meu amor e gratidão, para sempre. 


\section{AGRADECIMENTOS}

Aos meus pais e irmã, por todo amor e carinho com os quais me brindaram desde sempre; por toda a felicidade e proteção que me proporcionam a cada abraço e beijo carinhoso, a cada palavra de conforto e encorajamento, a cada sorriso amoroso; por todos os muitos esforços que sempre fizeram para que eu pudesse seguir meu caminho e meus sonhos. Todas as minhas conquistas foram e serão também deles.

À Mônica Lucas, pela excelente orientação ao longo de todo esse trabalho e por toda a amizade, ajuda, instrução e confiança, além da inspiração proporcionada por sua brilhante paixão pela arte, pesquisa e conhecimento.

À Livia Lanfranchi, por ajudar-me a enxergar a música e a beleza das coisas de forma mais profunda, sincera e humilde e por inspirar-me como músico e ser-humano através de nossa amizade.

Ao Bernardo Toledo Piza, cuja grande inteligência, vasto conhecimento e perspicaz humor apresentaram-me à organologia e à fascinante história dos instrumentos musicais. 
"Ao descrever os instrumentos musicais, devemos tratá-los como obras de arte de incriveis e inteligentes artesãos, que os trouxeram à existência através de esforço manual e intelectual. Aplicando planos precisos a materiais adequados, eles, habilidosamente, moldaram instrumentos que podem ser usados para proclamar a glória de Deus, ou - o que é perfeitamente legítimo - dar prazer à humanidade, com seus sons doces e harmoniosos." (PRAETORIUS, 1986 [1619], p. 21). 


\section{RESUMO}

FAGLIONI, Felipe. Instrumentos de sopro de madeira como alegoria retórica na música europeia do século XVIII. 2021. Tese (Doutorado em Musicologia) - Escola de Comunicações e Artes, Universidade de São Paulo, São Paulo, 2021.

A presente tese propõe um estudo das potencialidades alegóricas dos instrumentos musicais de sopro de madeira mais utilizados na música europeia ao longo do século XVIII, e de seu uso, por parte dos compositores, no discurso musical do período. Já na Antiguidade Grega, os instrumentos musicais foram compreendidos como detentores de significado alegórico, podendo, com isto, representar conceitos que iam além dos sons por eles produzidos. No ocidente, a recepção desta ideia gerou um vasto vocabulário de significações envolvendo os instrumentos e suas peculiaridades, frequentemente determinando seu uso na prática musical. Ao menos até o século XVIII, a visão e a utilização dos instrumentos musicais como alegorias manteve-se presente na cultura ocidental. Nos Setecentos, o emprego alegórico dos instrumentos ocorre sob perspectiva poético-retórica, segundo a qual eles são entendidos como potenciais representadores de paixões e caracteres, a partir da aplicação de lugarescomuns sancionados pela tradição. Partindo dessa premissa, esse estudo foca-se na melhor compreensão do uso setecentista dos instrumentos de sopro de madeira como alegoria retórica na música do período, bem como em uma reflexão sobre os resultados provenientes deste mesmo uso.

Palavras-chave: Instrumentos de sopro de madeira. Século XVIII. Alegoria retórica. 
FAGLIONI, Felipe. Woodwind instruments as rhetorical allegory in the 18th century european music. 2021. Tese (Doutorado em Musicologia) - Escola de Comunicações e Artes, Universidade de São Paulo, São Paulo, 2021.

This dissertation proposes a study of the allegorical potentialities of the woodwind instruments most in use in 18th century european music, and in its use by the composers in the musical discourse of that period. Since ancient Greece, the musical instruments were regarded as holders of allegorical meanings, and able to represent concepts beyond the sounds they produced. In the West, the reception of this idea generated a large vocabulary of meanings involving the instruments and their peculiarities, frequently determining their use in musical practice. At least till the 18th century, the vision and use of the musical instruments as allegories remained present in western culture. In the 1700's, the allegorical use of the instruments happens under a poetical-rhetorical perspective, according to which they are seen as potencial representatives of passions and characters, by the application of standard platitudes sanctioned by tradition. Based upon this premise, this study focuses on a better comprehension of the use of woodwind instruments as rhetorical allegory in the music of the 18th century and also on a discussion about the results of this kind of use.

Keywords: Woodwind instruments. 18th century. Rhetorical allegory. 


\section{SUMÁRIO}

1 INTRODUÇÃO, p. 11

2 INSTRUMENTOS MUSICAIS, ALEGORIA E RETÓRICA, p. 17

2.1 Alegorias e suas definições, p. 17

2.2 Os instrumentos musicais como alegoria, p. 25

3 ASPECTOS HISTÓRICOS DA ALEGORIA INSTRUMENTAL DA ANTIGUIDADE AO INÍCIO DO SÉCULO XVII, p. 28

3.1 Lira versus Aulos, p. 28

3.2 Instrumentos musicais no Iconologia, de Cesare Ripa, p. 41

3.3 Os instrumentos musicais e seu uso alegórico na prática musical, p. 80

4 O SÉCULO XVII E IMPORTANTES ACONTECIMENTOS ORGANOLÓGICOS, p. 109

5 OS INSTRUMENTOS DE SOPRO DE MADEIRA NO SÉCULO XVIII: CARACTERÍSTICAS, SIGNIFICADOS E USO ALEGÓRICO, p. 129

5.1 O Musikalisches Theatrum de Weigel, p. 129

5.2 Informações em escritos do século XVIII, p. 141

5.3 A flauta doce, p. 160

5.4 A flauta transversal, p. 179

5.5 O oboé, p. 199

5.6 A clarineta (e o chalumeau), p. 212

5.70 fagote, p. 234

6 A ALEGORIA INSTRUMENTAL NO FIM DO SÉCULO XVIII E INÍCIO DO XIX, p. 252

6.1 A orquestra clássica e a continuação de tradições, p. 252

6.2 Berlioz e o caráter dos instrumentos musicais, p. 261

7 CONCLUSÕES, p. 267

8 REFERÊNCIAS BIBLIOGRÁFICAS, p. 269

9 ANEXO, p. 275 


\section{INTRODUÇÃO}

Os instrumentos musicais sempre estiveram envoltos em contextos simbólicos não necessariamente ligados apenas a questões ou características musicais. Seja por seus aspectos físicos (tamanho, formato), sonoridade (forte ou suave, doce ou intensa), pelas maneiras e locais nos quais foram (ou ainda são) utilizados ou pela finalidade de seu uso, os instrumentos construídos para fazer música terminam por adquirir conotações extramusicais. Dessa forma, aos mesmos couberam, muitas vezes ao longo da história, funções que iam além daquelas de meros produtores de sons e, de forma mais profunda, os instrumentos assumiram papéis alegóricos, como representantes de conceitos que transcendiam os aspectos puramente sonoros.

$\mathrm{Na}$ tradição musical europeia essa concepção em relação aos instrumentos musicais sempre esteve presente, e, através de relatos escritos, iconografia e partituras, é possível notar que os instrumentos musicais mantiveram significados alegóricos através dos séculos, conservando, mesmo com o passar do tempo, algumas características conceituais essenciais.

$\mathrm{Na}$ Antiguidade Grega, concepções alegóricas referentes a diferentes instrumentos musicais são discutidas por Platão e Aristóteles e nas escrituras bíblicas encontram-se citações a respeito dos instrumentos que podem ser interpretadas através do mesmo viés. O uso alegórico dos instrumentos musicais se mantém durante a Idade Média e início da Renascença, como atestam autores como Johannes Tinctoris, ainda que seus significados específicos sejam, em parte, divergentes daqueles apresentados na Antiguidade. A partir do Humanismo este mesmo emprego passa a integrar o discurso poético-retórico, que se tornará crucial na criação e apresentação das artes em geral.

$\mathrm{Na}$ Renascença havia uma grande quantidade de instrumentos musicais em uso. Muito deles eram construídos em famílias formadas por instrumentos de igual natureza mas diversos tamanhos, abrangendo diferentes extensões, que juntas cobriam todo o gamma ut e podiam imitar as divisões da voz humana (no segundo livro do Syntagma Musicum de Praetorius, intitulado De Organographia e publicado entre 1618 e 1620, encontram-se ilustrações detalhadas de diversas famílias de 
instrumentos). Normalmente, os membros de uma mesma família eram agrupados em conjuntos conhecidos como consorts que podiam executar perfeitamente (inclusive com homogeneidade timbrística) a música polifônica do período. Apesar das documentações da época que confirmam que a utilização de consorts formados por instrumentos de diferentes famílias (os chamados broken consorts) não era algo incomum, conjuntos de instrumentos semelhantes foram utilizados com frequência ao longo dos séculos XV e XVI.

Consorts de instrumentos com maior volume de som eram normalmente utilizados para música militar, processional, executada ao ar livre, enquanto que aqueles formados por instrumentos de sons mais suaves eram utilizadas em música de caráter mais intimista, em ambientes fechados como igrejas e câmaras aristocráticas, onde poderiam ser ouvidos sem dificuldade. No entanto, alguns instrumentos e suas respectivas famílias eram preferidos em determinadas funções não só por suas características sonoras, mas também pelo significado alegórico que a tradição lhes conferira. Assim, obras de cunho real ou nobre eram normalmente caracterizadas pelo uso de trompetes; violas da gamba produziam sonoridades vinculadas à aristocracia e flautas e instrumentos de sopro de palheta eram associados à música pastoral ou referente à arcádia.

Durante muito tempo, em grande parte das composições tocadas por instrumentos (seja dobrando vozes em coros ou em peças puramente instrumentais) não se especificava quais deles deveriam ser utilizados. Fazia, no entanto, parte do treinamento musical de compositores e intérpretes saber escolhê-los e empregá-los de maneira decorosa, tanto por sua funcionalidade (extensão sonora, capacidades técnico-expressivas) quanto por suas possibilidades alegóricas.

Com o início do período Barroco, na transição do século XVI para o XVII, e a nova música sugerida pela seconda prattica, o emprego alegórico dos instrumentos musicais ganha força com a invenção da ópera. Essa nova forma de espetáculo, unindo música e representação teatral, consolidava em si, através de seu grande potencial catártico, a premissa estabelecida por Aristóteles na Poética, a partir da qual a música, assim como a palavra, é signo dos afetos da alma. Dentro desse contexto, o emprego de instrumentos musicais específicos, oriundos de diversas famílias e detentores de 
diferentes possibilidades de representação alegórica, assim como o uso de diferentes tipos de vozes, ganha importante fundamentação retórica nas obras desse gênero.

Nesse cenário, alguns instrumentos musicais que apresentavam possibilidades de imitação das vozes dentro do novo estilo monódico que se desenvolvia e ganhava força (ou seja, dotados de maiores extensões grave-agudo, flexibilidade de dinâmicas e capacidades expressivas que poderiam representar os diversos afetos necessários à "nova música") tendem fortemente a se dissociar dos consorts, ganhando uso solista e sendo aos poucos contemplados com avanços em sua técnica de execução e também com um repertório próprio e idiomático. Em meio à alta dramaticidade da música barroca, os instrumentos, mesmo em obras puramente instrumentais, continuam a desempenhar o papel de personagens, podendo representar caracteres, afetos, figuras, e contribuir, com isso, para o aumento da dramaticidade musical.

Como a música poderia (e, de certo modo, deveria) representar toda uma gama de distintos aspectos, vários instrumentos de diferentes naturezas e sonoridades passam a ser requisitados pelos compositores numa mesma obra. Um dos grandes exemplos encontra-se em L'Orfeo, de Monteverdi. Apesar da versão impressa da composição não conter, na sua maioria, partes específicas para cada instrumento (com raras e pontuais exceções), sabe-se que o compositor utilizou uma grande quantidade de diferentes instrumentos musicais (o prefácio das duas primeiras edições, de 1609 e 1615, lista todos aqueles que Monteverdi quis usar em sua obra e ao longo da partitura há indicações do compositor em relação ao uso dos mesmos), certamente na intenção de empregá-los alegórica e retoricamente em partes específicas da ópera (por exemplo, uma harpa que acompanha o cântico de Orfeu e representa a calma e beleza dos Campos Elíseos e um regal, com sua sonoridade estranhamente anasalada, usado em momentos que retratam a parte mais obscura do mundo dos mortos) e assim aumentar a capacidade expressiva de sua música.

Em fins do século XVII o uso dos instrumentos musicais passa a ser ainda mais específico e diversos compositores indicam com frequência em sua música orquestral e cênica instrumentos específicos e em quais momentos deveriam ser usados. As partituras de importantes compositores da época mostram já com mais clareza o desejo do uso de instrumentos específicos. Analisando-se essas partituras é possível perceber, agora com ainda mais força, que cada instrumento tende a ganhar uma 
individualização de caráter e que sua presença nas composições está longe de ser meramente casual.

O século seguinte, que constitui o objeto específico deste trabalho, continua e reforça essa tradição, atestada nas obras de muitos de seus compositores, que mostram grande atenção em relação à escolha e ao uso dos instrumentos musicais.

Até o final do século XVIII as obras orquestrais não se utilizam sempre de formações instrumentais iguais. Diferentemente das orquestras normalmente requisitadas pelos compositores a partir do início do século XIX, que possuem quase sempre o mesmo efetivo instrumental de cordas, sopros e percussão, os grupos orquestrais ao longo do século XVIII mostram-se com instrumentações bastante variadas. Os compositores da época, não tendo ainda em mente uma orquestra de formação instrumental fixa, escolhem para suas diferentes obras efetivos instrumentais distintos. Dessa forma, a instrumentação de uma peça pode representar nessa época um aspecto bastante importante da mesma, potencializando o discurso musical.

Todas essas informações contribuem para que se levante questões como: no contexto do século XVIII, quais seriam, afinal, as potencialidades de representação alegórico-retórica envolvendo os instrumentos musicais mais utilizados pelos compositores? Seriam essas representações claras ou explícitas aos ouvintes? Seria possível, por exemplo, que apenas pela instrumentação de determinada ária ou trecho de cantata ou ópera o público poderia supor qual o tipo de afeto representado pelo compositor ou qual temática seria ali abordada? Se, na então usual musica poetica do período, determinadas figuras e elementos musicais serviam para exprimir afetos específicos, poderia o timbre de um instrumento representar, por si só, algo parecido? Ou ainda, uma mudança na instrumentação de uma peça poderia modificar o sentido da mesma?

A utilização dos instrumentos de sopro de madeira fornece um excelente e intrigante material para o estudo do uso alegórico e retórico dos mesmos por parte dos compositores. No século XVIII, a flauta transversal, a flauta doce, o oboé, o fagote e a clarineta (mais tardiamente) eram instrumentos conhecidos e utilizados por compositores em toda a Europa. Apesar de pertencerem a uma mesma família, esses instrumentos apresentavam timbres e tessituras distintos e, assim, podiam 
representar na música características muito diferentes. Cada um deles possuía um histórico de utilização e desenvolvimento dentro da cultura europeia e, portanto, carregava consigo vários aspectos simbólicos, extramusicais. Como dito, esses instrumentos ainda não ocupavam na época uma posição fixa nos grupos orquestrais sendo, antes, adendos ao mais tradicional e numeroso grupo de cordas. As madeiras eram inicialmente utilizadas, portanto, como instrumentos que traziam novas cores ao timbre orquestral. De certa forma, eram instrumentos de "efeitos especiais", e é certo que os compositores do período que se preocupavam com as capacidades expressivas da orquestra, não deixaram de lado as possibilidades de representação desses instrumentos.

Nesse contexto, a fim de explicitar a hipótese da importância do uso alegórico dos instrumentos de sopro de madeira no século XVIII, por parte de seus compositores, como forte ferramenta aplicada à música da época para a potencialização de seu discurso e, consequentemente, de sua compreensão e absorção por parte do público, bem como de procurar mostrar utilizações características e singulares de cada um dos mencionados instrumentos, esta tese busca analisar o estado das concepções extramusicais que envolviam os mencionados sopros durante o referido momento histórico e apontar usos significativos das mesmas em meio ao discurso retórico formador de obras musicais do período, nas quais eram utilizadas.

Para tanto, elabora-se o presente estudo em diferentes partes a fim de possibilitar a contextualização da situação do objeto da pesquisa no século XVIII a partir de informações provenientes de períodos anteriores e também de uma fase posterior.

Assim, a tese inicia-se com a definição de alegoria e dos meios através dos quais a mesma foi tradicionalmente aplicada, conectando-a, em seguida, aos instrumentos musicais, que tantas vezes serão utilizados de forma alegórica.

A partir disso, o estudo dedica-se a apontar diversas evidências do uso alegórico dos instrumentos em momentos históricos antecedentes ao século XVIII, indo desde a complexa dualidade da lira e do aulos presente na Antiguidade Clássica até o início do século XVII, com o surgimento da ópera barroca, sendo as referidas evidências provenientes tanto de documentos musicais e de relatos de atividades 
musicais nos diferentes períodos como de iconografias e outras documentações que não tratam especificamente de música, mas contêm informações relevantes sobre o assunto. Alcançado o século XVII, passa-se o foco para os instrumentos de sopro, comentando-se a respeito das importantes mudanças pelas quais diversos deles passaram na época a fim de serem aceitos no novo grupo orquestral que se formava. A citada "seleção" seiscentista dos sopros permite a escolha dos instrumentos de madeira considerados mais importantes em meio à "alta música", os mais utilizados pelos compositores daquele e dos seguintes períodos e cuja maioria conseguirá um posto fixo na orquestra clássica que se formará tempos depois. Desses sopros de madeira ocupa-se todo o restante do texto, procurando trazer informações a respeito do potencial extramusical de cada um deles, de seus primeiros usos através desse viés no século XVII e de sua trajetória pelo XVIII. Encerrando a tese, tecem-se alguns comentários a respeito da continuação do uso alegórico dos instrumentos na primeira metade do século XIX, e da importância através da qual o mesmo uso teria sido vislumbrado à época.

Esta pesquisa, de caráter bibliográfico, documental e analítico, fundamenta-se em um forte apoio organológico, principalmente aquele relacionado à história dos instrumentos musicais, sendo ela o pilar principal deste estudo. Na intenção de traçar um panorama do uso dos instrumentos como alegoria especialmente no século XVIII europeu, o trabalho não é focado na obra de apenas um ou outro autor (ainda que alguns deles tenham aparições mais recorrentes), nem em um local específico da Europa. Antes, o mesmo busca apresentar exemplos que evidenciem os sopros de madeira como ferramenta alegórica do discurso musical retórico, não importando a mente criativa por trás desse uso ou o lugar do qual teria sido proveniente. 


\section{INSTRUMENTOS MUSICAIS, ALEGORIA E RETÓRICA}

\subsection{Alegorias, alguns aspectos de sua história e definições}

Duas breves e abrangentes definições encontradas no dicionário Aurélio no verbete "alegoria" explicam o termo como "exposição de um pensamento sob forma figurada" e "ficção que representa uma coisa para dar ideia de outra" (1995, p. 28). Massaud Moisés inicia sua definição de "alegoria", dentro de seu Dicionário de Termos Literários, classificando-a como um "discurso acerca de uma coisa para fazer compreender outra" (2004, p.14). De forma mais técnica, no entanto, o autor João Adolfo Hansen, em seu referencial trabalho sobre a alegoria, a define, seguindo o pensamento quintilianesco presente nas Institutione Oratoria, como uma "metáfora continuada que diz $b$ para significar $a$, baseando-se numa relação de semelhança entre $b$ e $a$ " (HANSEN, 2006, p. 225). Dessa forma, é possível pensar a alegoria (do grego allós para outro e agourein para falar) como uma espécie de figura de linguagem que operará em distintas situações sempre através da oposição entre um sentido próprio e outro figurado.

\subsubsection{Distintas alegorias}

Em seus desdobramentos, a alegoria pode ser dividida em dois tipos: um construtivo, retoricamente expressivo e criativo, e outro interpretativo e crítico. 0 primeiro (do qual se ocupará mais diretamente essa tese) é chamado "alegoria dos poetas", também descrita por Hansen (2006, p. 7) como "expressão alegórica, técnica metafórica de representar e personificar abstrações". Já o segundo é conhecido como "alegoria dos teólogos" ou "alegoria hermenêutica", que como define o mesmo autor (2006, p. 8) "não é um modo de expressão verbal retórico-poética, mas de interpretação religiosa de coisas, homens e eventos figurados em textos sagrados". Ambas são, portanto, distintas, ainda que a segunda possa conter a primeira em meio a suas aplicações.

Cronologicamente mais recente em sua utilização, a alegoria hermenêutica tem origem no medievo e é estritamente ligada à figura dos pensadores cristãos do período 
que, exemplificando-se brevemente, através de uma série de regras de interpretação, analisarão as sagradas Escrituras Bíblicas e encontrarão entre elas conexões implícitas, reveladoras de mistérios divinos. Como explica Hansen $(2006$, p. 12) os padres medievais 'fizeram a distinção de sentido literal, expresso por 'letras' de palavras humanas como sentido literal próprio e sentido literal figurado, e sentido espiritual, revelado por coisas, homens e acontecimentos das Escrituras". Esse sentido espiritual, ou as verdades sagradas, são buscadas através de um olhar singular sobre tais aspectos, que são assim lidos não propriamente pelas palavras que os designam, mas antes como figuras alegóricas, representantes de algo que transpassa seu sentido literal. Desse modo, a alegoria hermenêutica é "uma 'semântica' de realidades reveladas pelas coisas representadas pelas palavras, não importa sejam palavras de sentido próprio ou figurado" (HANSEN, 2006, p. 92).

Já a alegoria dita "dos poetas" se faz presente desde a Antiguidade, tendo sido assim nomeada por greco-romanos e cristãos. De caráter essencialmente linguístico, ela se encontra fortemente conectada aos preceitos da retórica e a seu alto nível de importância em relação aos modos de manisfestação e validação dos discursos de toda uma época. Esse tipo de alegoria será retoricamente visto e empregado como um dispositivo expressivo, como ornatus, ou seja, ornamentação dentro do discurso. Trata-se, portanto, de um artifício de embelezamento e, consequentemente, de valorização ou melhoria de um texto.

Sendo vista na Antiguidade como modalidade da elocução, a alegoria dos poetas é uma maneira de expressão verbal retórico-poética, um jogo de palavras cuja presença intenciona potencializar ou intensificar determinada ideia de um discurso através da transposição de significados. Aguiar e Silva (2010, p. 104) explica:

\footnotetext{
Na tradição retórica latina, desde a Rethorica ad Herennium até ao De Oratore e ao Orator de Cícero e à Institutio Oratoria de Quintiliano, a alegoria é caracterizada como sendo um tropo ${ }^{1}$, cuja designação grega é traduzida por permutatio e por inversio, constituído por uma série contínua de metáforas. (...) Este entendimento ganhou secular e larga aceitação na retórica ocidental.
}

\footnotetext{
1 Hansen (2006, p. 230) define tropo como "retoricamente, transposição semântica de um signo presente para um signo ausente. A transposição se dá por semelhança (metáfora); por inclusão (sinédoque); por causalidade (metonímia); por oposição (ironia)". O autor complementa que "o estudo dos tropos é objeto da elocução, que também regula a ornamentação dos discursos na retórica antiga".
} 
Ao definir a alegoria como uma "metáfora continuada", Quintiliano, nas Institutione Oratoria, a caracteriza como quantitativa, ou seja, como resultado de um acúmulo de diversas metáforas que, isoladas, não bastam para caracterizar uma alegoria. A partir desse pensamento, Ceia (1998), diferenciando metáfora e alegoria, afirma que "a primeira considera apenas termos isolados; a segunda amplia-se a expressões e textos inteiros" e Hansen (2006, p. 30) explica que

ao passo que a metáfora é tropo de léxico, valendo por um termo isolado que substitui, (...) a alegoria equivale a um enunciado. Ela vale, portanto, por um "pensamento" que poderia ser expresso por um discurso simples, sem ornamento.

Assim, a interpretação da alegoria necessita de uma transposição contínua de um sentido figurado para um próprio, o que transpõe o nível poético e subliminar para o verdadeiro, trazendo à tona o real pensamento implicitamente presente no discurso.

A fim de exemplificar essa alegoria que "mostra uma coisa nas palavras e outra no sentido"2, Quintiliano cita Horácio, em suas Odes:

Novas ondas, ó nau, te tornarão

Ao mar alto. Oh, que fazes! Toma mão

Do porto fortemente...

O retor segue explicando de forma sucinta que nessa ode do poeta romano, a nau deve ser tomada pela república, as ondas pelas guerras civis e o porto pela paz e concórdia. Logo, o real significado do texto só pode ser obtido a partir da transposição e conexão das três metáforas empregadas.

Demonstrando a complexidade que envolve a formação da alegoria, Aguiar e Silva (2010, p.104) considera que

é particularmente elucidativa a análise comparativa da metáfora e da alegoria. A metáfora é uma figura de ordem microestrutural, ou seja, é delimitável num segmento preciso do discurso, modifica-se se houver alteração dos elementos formais, identifica-se de imediato e sem dificuldade e é interpretável em função de um contexto restrito. A alegoria é uma figura de ordem macroestrutural - não é delimitável num segmento

\footnotetext{
${ }^{2}$ Quintiliano fala de diferentes formas ou espécies de alegoria. A primeira delas mostra, como dito, algo em palavras e outra em sentido, enquanto que a segunda apresenta um sentido contrário e totalmente diverso do sentido das palavras (HANSEN, 2006, p. 29), caracterizando assim a ironia, que afirma para dizer outra coisa, para negar, e vice-versa.
} 
preciso do discurso, permanece se houver alteração dos elementos formais, não é identificável de imediato e só é interpretável em função de um contexto alargado.

As "metáforas continuadas" ainda poderiam tomar diversas proporções. 0 autor fala dos possíveis desdobramentos da alegoria:

(...) como fenómeno retórico-verbal de ordem macroestrutural, a alegoria pode manifestar-se num enunciado, numa sequência de enunciados, em textos mais ou menos longos genologicamente configurados como a parábola, a fábula, o exemplo, o romance alegórico, o drama alegórico, etc. A metáfora, como fenómeno retórico-verbal de ordem microestrutural, não detém similar capacidade expansiva, embora possa adquiri-la, ao converterse em alegoria.

Fazendo parte do tipo de discurso vigente na Antiguidade, a alegoria e suas aplicações eram, logicamente, regidas pelos preceitos da retórica clássica, e sua boa utilização dependia de uma série de regras que deveriam ser seguidas decorosamente. A elaboração e aplicação prática da alegoria, responsabilidades dos autores, bem como sua recepção e compreensão por parte do público receptor baseava-se num conjunto de normas conhecidas por ambas as partes. Afinal, desse conhecimento dependia o sucesso do uso da alegoria, sem o qual ela se tornaria incompreensível ou sem sentido. A esse respeito, afirma Hansen:

\footnotetext{
Pensada como dispositivo retórico para a expressão, a alegoria faz parte de um conjunto de preceitos técnicos que regulamentam as ocasiões em que o discurso pode ser ornamentado. As regras fornecem lugares-comuns - topoi (grego) ou loci (latim) - e vocabulário para substituição figurada de determinado discurso, tido como simples ou próprio, tratando de determinado campo temático. Assim, estática ou dinâmica, descritiva ou narrativa, a alegoria é procedimento intencional do autor do discurso; sua interpretação, ato do receptor, também está prevista por regras que estabelecem sua maior ou menor clareza, de acordo com o gênero e a circunstância do discurso. (HANSEN, 2006, p. 9)
}

Dos mencionados lugares-comuns dependerá quase sempre a alegoria, uma vez que as transposições que se fazem através dela necessárias dependem também, por sua vez, de todo um vocabulário pré-estabelecido e conhecido, presente em variadas formas nos diversos períodos históricos que farão uso de ornamentação alegórica em seus discursos. 


\title{
2.1.2 As alegorias no Renascimento
}

O Renascimento trouxe ao mundo intelectual e artístico um novo e extenso universo cultural dentro do qual expressar-se e nesse contexto o século XV veria o surgimento de uma nova forma de uso e interpretação alegórica. Através dos pensamentos neoplatônicos oriundos dos estudos e descobrimentos realizados pelos intelectuais de Florença, entre os quais destaca-se o nome de Marsílio Ficino, a alegoria estará sujeita a novas visões. Como explica Hansen:

\begin{abstract}
[para os florentinos] a alegoria deixa de ser pensada como a antiga instituição retórica a pensara: tradução figurada de um sentido próprio. Deixa, também, de funcionar como na hermenêutica medieval, que sob a letra da Escritura revelava a voz do Autor nas coisas. Em Marsílio Ficino, ela é um misto retórico-hermenêutico, pois, segundo a orientação neoplatônica da sua interpretação, as "coisas elevadas" da ordem poética estão para além de qualquer conceito e a alegoria efetua um sentido inefável. (HANSEN, 2006, p. 140)
\end{abstract}

Essa questão explica-se pelo fato de que os estudiosos da Florença renascentista passam a ter, graças à descoberta e tradução de documentos filosóficos e poéticos antigos, aos quais somam-se os de origem medieval, um extenso acervo abrangendo conhecimento de origem cristã e pagã. O deslumbramento que as culturas pagãs causarão sobre os intelectuais da Renascença fará com que esses textos antigos passem a ser vistos, de certo modo, com a mesma importância das sagradas Escrituras. Nasce então uma tendência de interpretação alegórica bastante eclética, através da qual a presença divina poderia ser vista de várias maneiras e em distintos lugares. Hansen afirma (2006, p. 142):“O método alegórico florentino baseia-se, pois, numa pressuposição: o ser divino se revela de várias maneiras e a tarefa do erudito-poeta é rastreá-lo em todas as suas manifestações, demonstrando a unidade na diversidade."

Assim, num misto de conhecimento diversificado, as coisas terminam por mesclar-se:

$\mathrm{Na}$ interrogação constante dos vestígios e monumentos dessa Antiguidade inscrições, mitos, textos poéticos, motivos de arquitetura, ritos, hieróglifos egípcios, textos de filósofos e magos, numerologia - o sábio tem o saber hermético que lhe permite decifrar os mistérios, remontando a uma 
"história" indiferenciada de mistos, em que a leitura produz, por exemplo, um Platão já cristão-virgiliano, um Cristo sempre platônico-virgiliano, um Virgílio platônico-cristão... (HANSEN, 2006, p. 144).

Esse vasto universo fornece material para interpretações e inspiração para invenções e a alegoria aparece, nesse meio, multifacetada, podendo ser ao mesmo tempo construtiva ou crítica.

Quando tende à hermenêutica, debruça-se sobre a busca e decifração dos enigmas presentes nesse mencionado novo mundo de possibilidades interpretativas dos mistérios ou (como escreve o próprio Ficino) das "coisas elevadas, ocultas nas fontes mesmas do divino". Quando retórica-ornamental, no entanto, apresenta uma diferença significativa em relação à sua utilização essencialmente linguística da Antiguidade, relação essa que interessa deveras a esta tese, uma vez que aqui a alegoria poética deixa de ser exclusivamente literária e se conecta também às artes. Ela deixa, portanto, de ser puramente verbal para apresentar-se também plástica (entre outras possibilidades).

Como afirma Aguiar e Silva (2010, p. 104), a alegoria

pode fazer parte de um texto icónico-verbal, como o emblema, e pode ser constituída por um artefacto icónico não verbal, como um quadro de pintura que represente, por exemplo, o amor divino e o amor profano ou como uma estátua que represente a justiça.

Questão muito relevante é o fato de que dentro das divisões propostas pela Retórica, a alegoria, em meio às artes, passa a figurar também como dispositivo da invenção, como ars inveniendi, incluindo ali o material pensado somente como elocução pelos retores antigos. Assim, sendo parte da inventio, a alegoria mostra-se importante fator dentre os referenciais primeiros da criação artística, auxiliando nas construções da imaginação poética.

Entre esses novos contextos renascentistas, a alegoria envolve-se de misticismos em torno das aproximações com o divino. Hansen afirma (2006, p. 178-9) que "Os neoplatônicos florentinos do século XV teosofaram a alegoria como expressão e interpretação de mistérios", e continua, sobre suas conexões com as artes: 
[os neoplatônicos] seu caráter mágico, misterioso e místico. Caráter aliás segundo ou terceiro, pois ela é forma de forma de Forma, numa "subida" contínua do sensível para o inteligível, do inteligível para o inefável (...) Pelo misticismo, a teosofia florentina implica sempre um excesso de sentido inexprimível, ao qual a alegoria faz alusões poéticas, no seu jogo duplo de mostrar e ocultar.

Apesar da força da visão alegórica neoplatônica dentro da tradição mística criada pelos florentinos, o século XVI verá o nascimento de uma corrente de pensamento aristotélico que trará consigo uma nova abordagem em relação à alegoria, graças à descoberta e consequente popularização da Poética de Aristóteles no mencionado período e também no século seguinte.

Novamente conectada com força à Retórica (graças às apropriações da arte oratória por parte dos reformistas e contra-reformistas) a alegoria volta a ser vislumbrada à maneira antiga, como figura retórica de ornamentação, como "metáfora continuada". No entanto, aqui seu campo de atuação é mais extenso do que na Antiguidade, estendendo-se aos domínios artísticos. O chamado "aristotelismo" verá a alegoria de forma um tanto quanto pragmática, dando a ela uma série de regras finitas de utilização, obtidas através da leitura de também outros documentos aristotélicos como a Lógica e a Retórica e das diversas definições e classificações ali propostas.

Desse modo, para Hansen (2006, p. 179-80) a alegoria aristotélica é uma "definição ilustrada", sendo que

o aristotelismo permite uma regulação técnica da alegoria no século XVI e, extensivamente, no século XVII, pois postula que: a) a expressão alegórica imita as articulações do pensamento, que são as da coisa (res). Assim, a formulação alegórica admite uma lógica de conceito, pela definição, classificação, divisão, subdivisão, etc; b) a invenção e a representação artísticas refazem o conceito em matéria, de modo que o processo fundamenta um técnica de produção de imagens, metáforas e alegorias. Como o conceito a ser figurado é, antes de tudo, um pensamento, a alegoria torna-se uma invenção, ou seja, uma técnica artística de dar forma a um pensamento numa matéria por meio de "imagens".

O autor indica também três pressupostos - invenção, imitação e arte - nos quais baseia-se o processo de figuração alegórica segundo o aristotelismo:

a invenção do poeta ou artífice é um produto de seu pensamento; a imitação de modelos artísticos é um instrumento da invenção; a arte é o ato da execução por meios técnicos, adequados aos gêneros, verossimilhanças e decoros. 
Apesar de mesclar-se às ideias da tradição neoplatônica florentina, a visão aristotélica da alegoria poético-retórica será, como mencionado, recorrente nos séculos XVI e XVII (estendendo-se também até o XVIII). Fica claro que seus preceitos e definições bem delimitadas servirão para criar um uso muito regrado da alegoria nesses períodos. No que concerne as artes, as regras de utilização alegórica conduzirão artista e público, de forma semelhante ao que ocorria na Antiguidade, a um vocabulário ou repertório específico de representações bem como ao modo de realizálas. O conhecimento desse repertório é essencial para a compreensão das alegorias e, consequentemente, para a boa comunicação entre o artífice e seu receptor. A Retórica tomará a frente como condutora do discurso artístico e de seu uso da alegoria, também ditando suas regras e a partir disso, caberá ao artista caminhar corretamente dentro desse mundo regrado e decoroso, repleto de definições claras e lugarescomuns.

Como visto, os domínios da alegoria estenderam-se ao longo da história, indo da exclusividade literária até a relevante presença no mundo das artes, entre elas as artes plásticas e também a música, onde aspectos alegóricos podem ser encontrados nos diversos meios que se unem para produzí-la. Entre esses meios encontram-se os instrumentos musicais. 


\subsection{Os instrumentos musicais como alegoria}

Os instrumentos musicais foram, por muitas vezes ao longo da história, utilizados em meio às artes de forma alegórica. Nesse contexto, seu uso pôde trazer ao âmbito no qual aplicado um significado, ou ainda uma gama de diferentes sentidos, que ia além do puramente musical. Logicamente, o papel primordial de um instrumento musical é realizar música, através de seu potencial sonoro-expressivo aplicado aos diversos estilos, pensamentos e formas de se enxergar e tratar a música vigentes em cada período de sua história. No entanto, todo um conjunto de características extramusicais associadas aos instrumentos formaram com o tempo um vocabulário de lugares-comuns intrinsicamente existentes na própria presença do mesmo, tornando sua utilização, musical ou não, vinculada a um repertório repleto de significações. Portanto, um instrumento musical torna-se, nesse cenário, um meio alegórico.

Sem dar ênfase às possíveis formas de associação e interpretações que poderiam inserir os instrumentos musicais em análises hermenêuticas naturais das já vistas "alegorias dos teólogos", concentrar-se-á o pensamento em direção à visão da aplicação artística e ornamental dos instrumentos, conectadas, portanto, às alegorias poético-retóricas. Assim, o interesse aqui será seu uso como ornatus dentro de diferentes discursos artísticos nos quais poderão ser aplicados, com concentração em suas utilizações na música.

A alegoria ornamental liga-se fortemente à Retórica e a suas regras de construção do bom discurso. Sua presença traz a ele, portanto, embelezamento e enriquecimento, aumentando sua complexidade e consequentemente, seu valor intelectual e artístico. Seguindo o pensamento alegórico renascentista, a aplicação dos instrumentos musicais e seus diversos significados se faz presente na invenção, nos primeiros passos da criação artística, quando um ou mais instrumentos são selecionados, como alegorias, para comporem o discurso pretendido pelo artesão. Uma vez que seu uso ornamenta uma obra, trazendo a ela diversos significados, ele pode auxiliar em sua elocução. Os instrumentos musicais são, então, a partir da escolha de sua presença e da forma como utilizados, partes integrantes, ao mesmo tempo, da Inventio e da Elocutio. 
Como mencionado, o uso alegórico dos instrumentos musicais pode dar-se de diferentes formas, em diferentes meios artísticos. Sendo assim, eles são capazes de servir como ferramentas alegóricas na poesia, nas artes plásticas e, é claro, na música. No entanto, cada um desses meios pode utilizá-los com diferentes enfoques, partindo de suas potencialidades e dos diferentes aspectos alegóricos que podem ser por eles melhor ressaltados.

As letras fazem deles citações e descrições e a leitura das mesmas levará a imaginação do leitor às diversas significações alegóricas possíveis. As artes plásticas partem da representação material mais direta dos instrumentos e seus aspectos físicos. Sua visão, dentro dos diversos modos de representação bem como dos contextos nos quais podem ser inseridos, por exemplo, em um desenho, pintura ou escultura, levantará seus aspectos alegóricos ao espectador. Na música, porém, são principalmente as característica sonoras dos instrumentos as responsáveis por carregar consigo seus sentidos alegóricos; aqui é essencialmente o som o propagador da alegoria. No entanto, é necessário levar-se em conta também as situações de concertos ou apresentações nas quais os instrumentos são, ao mesmo tempo, vistos e ouvidos, podendo trazer à tona os sentidos alegóricos através da visão e da audição. Dessa forma, a experiência alegórica musical, quando vivenciada pelo espectadorouvinte, poderia ser considerada como das mais complexas e transformadoras.

Diferentes aspectos fazem dos instrumentos musicais alegorias. Em cada época, um instrumento pode trazer consigo uma série de pensamentos implícitos provenientes de um repertório específico de lugares-comuns acumulados por tradição. ${ }^{3}$ Assim, termina por ser, ele próprio, continente de diversas ideias, ou ainda uma espécie distinta de metáfora continuada, trazendo consigo a representação de um ou mais pensamentos completos a ele associados. Esses pensamentos interligados ao instrumento podem ter, por sua vez, origem diversa, entre as quais é possível citar, por exemplo, o uso, ou ainda a tradição de utilização de um instrumento, que pode associá-lo a um ambiente ou espaço no qual é realizada determinada atividade com

\footnotetext{
${ }^{3}$ Não é possível descartar a possibilidade do uso alegórico de um instrumento a partir de concepções originais ou próprias de um artista que o utiliza. No entanto, dentro do contexto retórico dominante até o século XVIII, quando os preceitos da arte oratória, detentores de um vasto léxico pré-determinado, são fundamentais para a construção da obra de arte, a pura "originalidade" não é o caminho mais procurado e bem-visto pelos criadores.
} 
características e finalidades específicas; as características musicais particulares a cada instrumento, como seu timbre, tessitura e possibilidades técnicas, que podem vinculálos a aspectos extramusicais correspondentes; associações sacras ou míticas referentes às origens e potencialidades e efeitos de um instrumento sobre seus ouvintes; aspectos físicos e de construção de um instrumento, que podem associá-lo a coisas ou objetos de caráter similar.

A história nos mostra que, não raramente, um instrumento musical pôde trazer consigo não apenas um dos aspectos citados, mas também um acúmulo ou mescla dos mesmos. Assim, dentro de um universo retoricamente decoroso, a citação, a visão e a audição de um instrumento poderia gerar, de forma riquíssima, compreensões e reações variadas. Da Antiguidade à Idade Moderna, ao menos, isso foi uma realidade. 


\section{ASPECTOS HISTÓRICOS DA ALEGORIA INSTRUMENTAL DA ANTIGUIDADE AO INÍCIO DO SÉCULO XVII}

\subsection{Lira versus Aulos}

Em meio aos mitos gregos encontram-se histórias que podem ser consideradas como algumas das mais antigas narrativas envolvendo instrumentos musicais e que abrirão caminho para discussões a respeito de aspectos simbólicos ${ }^{4}$ atribuídos a eles e, consequentemente, a seu uso alegórico e retórico em meio às práticas musicais da época.

Essas histórias envolvem a deusa Atena e sua criação e rejeição de um instrumento e também o deus Apolo em um "duelo musical”, enfrentando um ser de caráter inferior ao seu e saindo-se vitorioso. Logicamente, nesses mitos os instrumentos musicais desempenham um papel fundamental, tanto para o desenrolar dos acontecimentos das narrativas quanto para seu significado alegórico e moral. Mais do que coadjuvantes, os instrumentos têm aqui uma importância que pode situá-los no papel de personagens principais.

\footnotetext{
${ }^{4} \mathrm{O}$ termo símbolo e seus desdobramentos pode denotar diferentes significados, dependendo da época e do contexto nos quais é utilizado, o que talvez venha a causar certa confusão se não explicado. No Romantismo, por exemplo, o símbolo será pensado como algo oposto à alegoria. Hansen (2006, p.15-17) explica que, pelo viés romântico, "a alegoria é então conceituada como particular para o universal (Schelling, Goethe), como invólucro ou revestimento exterior de uma abstração. Segundo os românticos, o símbolo - que a tradição antiga, greco-latina, medieval e renascentista não distinguia da alegoria - é uma espécie de paradigma ou classe da qual ele é o único elemento. Por isso, sua significação é sempre imediata; em sua particularidade, ele contém ou expressa o geral. Por exemplo, a cruz e o Cristianismo. Oposta ao símbolo, a alegoria é teorizada como forma racionalista, artificial, mecânica, árida e fria. Retoricamente, a alegoria diz $b$ para significar $a$, como se escreveu, observandose que os dois níveis (designação concretizante $b$ e significação abstrata $a$ ) são mantidos em correlação virtualmente aberta, que admite a inclusão de novos significados. Além disso, a alegoria pode funcionar por mera transposição: o significado da designação $b$ pode ser totalmente independente do significado da abstração $a($ (...). Assim, os românticos postularam que a alegoria é exterior ao pensamento, como um luxo discursivo que se permite dispender signos inúteis para a economia de sentido, que poderia ser significado imediatamente." Mais tarde, ao definir novamente o termo símbolo, Hansen afirma mais uma vez que "a distinção [entre alegoria e símbolo] é histórica, isto é, datada do Romantismo. A Antiguidade, a Idade Média e o Renascimento não a operam." (2006, p.229). Nesta tese, que trata particularmente de períodos anteriores ao Romantismo, a distinção entre alegoria e símbolo, realizada pelo citado movimento, não será feita, assim como em grande parte dos documentos consultados para a realização desse texto. Portanto, aqui, os termos alegoria e símbolo não serão antagonistas. Pelo contrário, eles se complementarão.
} 
O desafiante de Apolo no duelo com instrumentos surge na figura de Mársias, um sátiro (criatura meio-humana dotada de cauda de cavalo e orelhas pontudas). 0 deus entra no duelo acompanhado de sua lira, enquanto que seu adversário o confronta com o aulos.

Os dois instrumentos musicais mencionados são emblemáticos junto à cultura Grega, sendo que ambos faziam parte fortemente da vida e do fazer musicais da antiga Grécia. Muito provavelmente, é devido a isso que são eles os envolvidos nos mitos.

Como argumenta Winternitz (1979, p.150, tradução nossa) o mito de Apolo e Mársias, que conecta-se ao de Atena e a criação de seu artefato tem um caráter sério e trágico e desperta uma reflexão moral profunda. É através dessa história que criar-se-á a clássica dicotomia entre a lira e o aulos, tão viva em meio à cultura dos Gregos. Winternitz afirma que

(...) a história de Mársias não só mostra a hybris ${ }^{5}$ punida mas tem um sabor e mensagem especiais. É uma condensação poética de um eterno conflito, o antagonismo entre dois reinos musicais, entre instrumentos de corda e de sopro. $^{6}$

Portanto, a oposição entre esses instrumentos e suas diferentes características e valores terminará por representar muito mais do que suas participações nas histórias.

\subsubsection{Os mitos}

Existem várias descrições dos mitos envolvendo a lira e o aulos. Cerqueira (2012, p. 67) indica algumas fontes, oriundas de um período compreendido desde o século VI a.C. até o século II d. C., no qual as histórias são narradas com maior riqueza de detalhes, sendo seus autores Píndaro, Melanípedes, Apolodoro, Xenofonte, Heródoto e Ovídio. Winternitz (1979, p. 151) cita ainda Plutarco e Filóstrato como outras fontes de informação das mesmas narrativas. Como é de se esperar, tendo sido

\footnotetext{
${ }^{5}$ Esse termo grego designa aquilo que é ousado, descomedido, presunçoso, insolente ou arrogante.

6 “ (...) the Marsyas history not only shows hybris punished but has a special flavour and message. It is a poetic condensation of an eternal conflict, the antagonism between two musical realms, between string and wind instruments."
} 
os mitos contados por diferentes autores ao longo de praticamente oito séculos, as versões apresentam algumas diferenças acerca de detalhes das histórias. Mesmo assim, é possível, de uma forma geral, narrar os mitos da criação do aulos e do duelo de Apolo e Mársias da seguinte forma:

Atena, a partir de um pedaço de bambu, cria um instrumento musical de sopro, o aulos, e resolve tocá-lo em uma festividade junto a outros deuses. No entanto, tocando o instrumento a deusa fica com as bochechas infladas e as feições do rosto deturpadas e por isso acaba sendo vítima de chacota de outros deuses presentes na festa, que riem dela. Envergonhada com a situação, Atena vai até um bosque na região da Frígia, e ali, sozinha, toca o aulos na beira de um rio, enquanto observa seu reflexo. Vendo que seu rosto fica "deformado" enquanto faz soar o instrumento, a deusa se irrita com a situação e descarta o aulos, amaldiçoando-o. Então, um sátiro nativo daquela região, chamado Mársias, encontra o instrumento e começa a tocá-lo, apesar das advertências da deusa para que não o fizesse. Com o passar do tempo, ele se torna uma espécie de virtuoso do aulos, sendo capaz de tocá-lo com invejável destreza. Assim, tomado por vaidade e insolência, o sátiro resolve desafiar o deus Apolo, famoso pela maravilhosa música que fazia com sua lira, a um duelo que decidiria qual dos dois seria o melhor intérprete. Apolo aceita o desafio e impõe a condição de que o vencedor poderia fazer com o perdedor aquilo que the conviesse. As musas são chamadas para julgar os contestantes. Mársias toca o aulos com tanta habilidade que Apolo teme por sua vitória e por isso usa de alguns truques: ele faz soar a lira virando o instrumento de ponta cabeça e canta ao mesmo tempo que toca, desafiando Mársias a fazer o mesmo com o aulos. Logicamente, o sátiro não consegue os mesmos feitos do deus e termina por ser derrotado. Então, Apolo, podendo fazer o que quisesse com o oponente, esfola-o vivo. O sangue que escorre de Mársias termina por formar um rio, que recebe o nome do sofrido sátiro.

Como mencionado, a interpretação dos mitos descritos acima será, através dos tempos, responsável por uma visão simbólica específica dos instrumentos de corda e de sopro. Winternitz (1979, p.152, tradução nossa) esclarece que o antagonismo entre lira e aulos terminará por representar 
não só a diferença entre o sereno e prateado som da corda de tripa pulsada e do lamurioso, estridente, gutural e excitante som do instrumento de sopro de bambu, apesar desse fato isolado já ser suficientemente carregado de significado simbólico em civilizações primitivas dos tempos mais antigos. Ele significa, na forma racionalizada dos mitos Gregos, o reino da introspecção, da razão, da medida - no senso Pitagórico literal da medição de cordas e intervalos, e no senso metafórico da proporção - em oposição ao reino da paixão cega: resumindo, o antagonismo entre Apolo e Dionísio. ${ }^{7}$

Para que se compreenda melhor os fatos que levaram os gregos a essa visão dualista sobre os dois tipos de instrumentos musicais, é necessário que se conheça a lira e o aulos, atentando-se em seu uso no contexto social da Grécia Antiga, uma vez que ambos apresentavam relevância naquele meio e momento histórico.

\subsubsection{Os instrumentos}

Conhece-se, hoje em dia, os instrumentos musicais gregos principalmente através de uma vasta iconografia da época (presente, por exemplo, na tão representativa cerâmica grega) além de fontes literárias e também de alguns instrumentos (ou parte deles) que chegaram aos dias atuais. Sabe-se que os gregos possuíam e utilizavam idiofones, cordofones, membranofones e aerofones. A respeito da variedade de instrumentos musicais dos quais dispunham, Mathiesen (1999, p.285, tradução nossa) comenta que

a rica gama de instrumentos musicais empregados na cultura grega - sendo eles nativos ou emprestados de outras culturas - atesta a importância de variadas cores em sua expressão musical. ${ }^{8}$

Ainda sobre os instrumentos, o autor também afirma (1999, p.286, tradução nossa) que

\footnotetext{
7 "This means not only the difference between the serene and silvery sound of plucked gut strings and the bleating, shrill, guturall, exciting sound of a reed pipe, though this alone is sufficiently charged with symbolic meaning in primitive civilizations from the earliest times. It means in the rationalized form of the Greek myths the realm of inhibition, of reason, of measure - in the literal Pythagorean sense of measuring strings and intervals, and in the metaphorical sense of measure - as opposed to the realm of blind passion: in short, the antagonism between Apollo and Dyonisus."

8 "The rich array of musical instruments employed in Greek culture - whether indigenous or borrowed from other cultures - attests to the importance of varied colors in their musical expression."
} 
não há dúvidas de que grande parte do apelo dos instrumentos musicais na cultura grega era estético. Seu som e aparência são com frequência descritos em termos sensuais e sua iconografia os coloca em cenas que vão do agradável e atraente ao impressionante e inspirador. Para além disso, a associação de instrumentos musicais com divindades em particular deu a base para a criação de respostas afetivas que poderiam complementar ou conflituar com as respostas suscitadas por outros meios como texto, ritmo, tempo, estrutura melódica, etc. ${ }^{9}$

Nessa contexto, a lira e o aulos são talvez os mais representativos instrumentos gregos, possuindo relação muito direta com divindades que terminam por contextualizá-los de formas deveras distintas.

Liras não são harpas. Os cordofones utilizados pelos gregos dividiam-se em basicamente dois grupos (ou classes): liras e saltérios. O primeiro deles compreende instrumentos cujas cordas eram tocadas por plectros enquanto que aqueles do segundo grupo tinham suas cordas acionadas diretamente pelos dedos do intérprete. Aquilo que conhecemos por harpa, portanto, descende de membros do grupo dos saltérios. Esses instrumentos, que chegavam a ter muitas cordas, podiam ser usados para executar melodias e eram associados a classes de músicos altamente qualificados. Ainda assim, o real papel desempenhado pelos saltérios na música grega ainda não é visto com muita clareza (MATHIESEN, 1999, p.270). Em compensação, sabe-se muito bem das funções desempenhadas pelas liras naquela situação.

As liras formavam o grupo mais relevante entre os cordofones gregos e constituíam-se por diferentes tipos de caixas de ressonância sobre as quais esticavamse cordas de vibração livre e tocadas, como mencionado anteriormente, por plectros. Mathiesen explica (1999, p.235, tradução nossa) que as liras

não parecem ter sido usadas para tocar melodias, complicadas ou não, exceto por poucos virtuoses; ao contrário, elas davam ao cantor algumas alturas estáveis - talvez mesmo uma escala completa - para usarem na centralização e articulação da canção. ${ }^{10}$

\footnotetext{
9 "There is no question that a large part of the appeal of musical instruments in Greek culture was aesthetic. Their sound and appearance are often decribed in sensual terms and their iconography places them in scenes that range from the pleasant and appealing to the impressive and inspiring. Beyond this, the association of musical instruments with particular divinities provided a basis for the creation of affective responses that might complement or conflict with the responses elicited by other means, such as text, rhythm, tempo, melodic structure, and so on."

10 "They do not appear to have been used to play melodies, complicated or otherwise, except by a few virtuosi; rather, they gave the singer certain stable pitches - perhaps even an entire scale - to use in centering and articulating a song."
} 
Havia distintos tipos de lira, entre eles a chelys (pequena e com a caixa de ressonância feita a partir de um casco de tartaruga, utilizada para lições de música e situações intimistas) e também a kithara, um instrumento de maior dimensão e ressonância, preferido dos virtuoses e utilizado em diversas situações, sendo frequentemente associada a Apolo. O formato característico desse instrumento foi a inspiração para a aparência através da qual as liras, em geral, são hoje em dia normalmente representadas.

Mesmo apresentando-se em formas distintas e sendo utilizada em também distintas funções, de ritos sacros à música para o teatro, a lira desempenhava um papel singular na educação musical dos gregos, educação essa vista por eles como algo de grande importância, tornando-se assim um artefato familiar e bem-quisto entre os cidadãos educados. Além disso, suas associações míticas com deuses como Apolo, Hermes ou ainda com as Musas, fizeram dela um símbolo de beleza, comedimento, temperança e inteligência. Logo, um instrumento de alta estirpe.

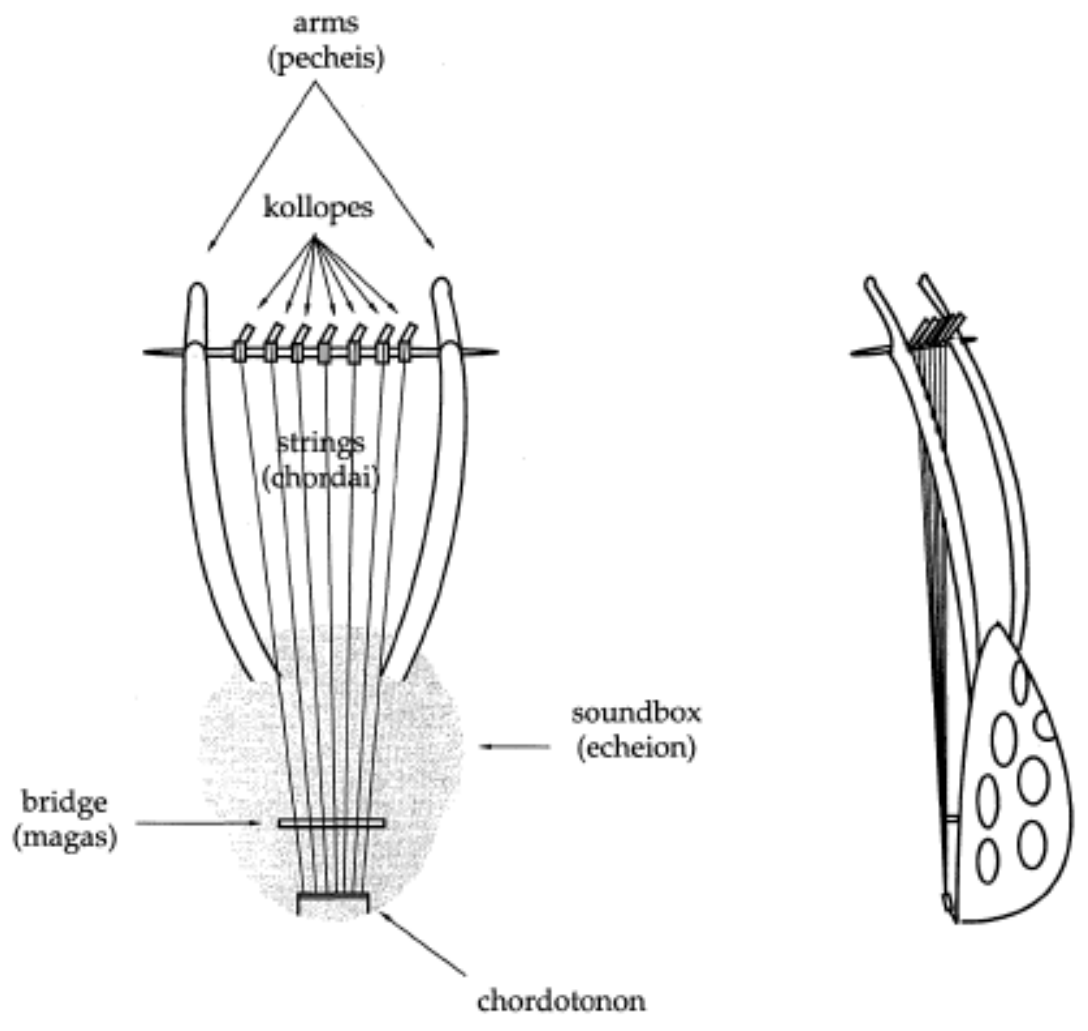

Fig. 1 - Esquema mostrando as diferentes partes de uma lira chelys, vista de frente e de lado. Nota-se a caixa acústica feita a partir de uma carapaça de tartaruga [soundbox], o fixador das cordas [chordotonon], o cavalete [bridge], as cordas [strings], cravelhas [kollopes] e braços [arms] (MATHIESEN, 1999) 


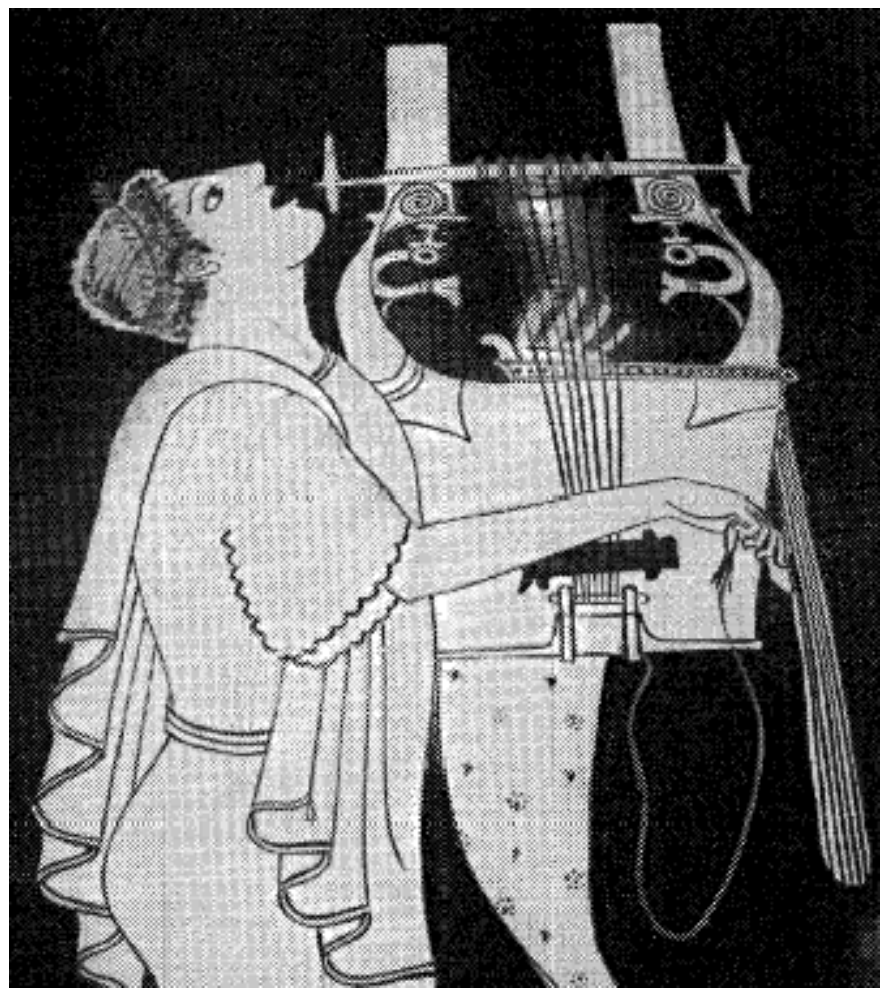

Fig. 2 - Pintura de uma kithara sendo tocada, presente em uma ânfora antiga. O intérprete do instrumento tem na mão direita um plectro (MATHIESEN, 1999)

Dentre os aerofones utilizados pelos gregos, o aulos é, do ponto de vista cultural, sem dúvida o mais icônico e significativo. São inúmeras as suas representações na iconografia da época e sabe-se de sua utilização em diversas vertentes da vida musical grega, o que mostra sua popularidade.

O aulos podia ter seu corpo construído por diversos materiais, de bambu a marfim, mas uma das características mais importantes em relação a sua sonoridade é o fato do instrumento normalmente utilizar-se de palhetas a fim de pôr o ar em vibração dentro de seu tubo. Portanto, o aulos (apesar de ainda haver uma série de incertezas a seu respeito) certamente não seria uma flauta. Winternitz (1979, p.150, tradução nossa) reforça essa questão dizendo que

por gerações, arqueólogos escolheram chamar o aulos - e seu correspondente romano, a tíbia - de "flauta", ou seja, um instrumento de sopro sem palhetas, enquanto que o aulos, de acordo com enorme evidência literária e visual, é um instrumento de sopro de palheta, ou mais precisamente um oboé, ou seja, um tubo munido de palheta dupla. ${ }^{11}$

11 "For generations archaeologists have chosen to call the aulos - and its Roman counterpart, the tibia a 'flute,' that is, a pipe without reeds, whereas the aulos according to overwhelming literary and visual evidence is a reed pipe, or more precisely an oboe, that is, a tube fitted with a double reed." 
Mathiesen (1999, p.182, tradução nossa) também discute a questão criticando o fato do termo grego que designa o instrumento, audós, ser ainda vertido como "flauta" em traduções recentes da literatura grega. O autor, no entanto, discorda de Winternitz, enfatizando:

Que o aulos não é uma flauta tem sido notado em numerosas ocasiões ao longo do século passado, mas ele também não é um oboé, que começou a ser oferecido como substituto por alguns estudiosos. De fato, o aulos é um aulos e soa como nenhum outro instrumento ocidental moderno. ${ }^{12}$

Também segundo o autor $(1999$, p.203) ainda não se sabe com toda certeza se as palhetas utilizadas nos aulos seriam duplas ou simples, o que também gera dúvidas sobre a afirmação de Winternitz anteriormente citada.

A nomeação do aulos como "flauta" é também nociva em relação a uma desejável concepção sonora do instrumento de palhetas e das reações que seu timbre causaria em seus ouvintes. Afinal, a sonoridade de uma flauta (ou seja, de um instrumento sem palhetas) assemelhar-se-ia muito mais àquela da syrinx, ou flauta de Pã, instrumento musical também presente na cultura grega antiga e que era, por sua vez, envolto de simbologia e aplicação prática muito distintas daquelas atribuídas ao aulos.

Embora pesquisas mais recentes sobre o instrumento mostrem que ele poderia se apresentar de formas diferentes, com características e sonoridades distintas, o próprio mito narrando sua criação evidencia que o aulos inventado por Atena teria sido um instrumento de palhetas, já que a "deformação" do rosto sofrida por aquele que o tocasse parece mais conectada ao tipo de embocadura necessária para se fazer soar um artefato dessa natureza. Sendo assim, é possível se pensar que o aulos primordial, mítico e envolto em simbologias, que tanto influenciou as culturas grega e romana com seu ruidoso som, utilizava-se de palhetas.

Apesar de usado para diversas funções sociais, o aulos teve sua figura e seu timbre poderoso, penetrante e excitante fortemente associados aos cultos dionisíacos e, consequentemente, ao orgiástico, impulsivo e desmedido, sendo sua imagem

12 "That the aulos is not a flute has been noted in numerous occasions throughout the past century, but neither is it an oboe, which has begun to be offered as a substitute by some scholars. In fact, the aulos is an aulos and sounds nothing like any modern Western musical instrument." 
refletida como completamente oposta àquela da lira. Esse fato, no entanto, não diminuiu sua popularidade, como atesta Mathiesen (1999, p.222, tradução nossa):

(...) por volta do século quinto a.C. o aulos tornara-se um dos dois ou três mais importantes instrumentos da cultura Grega. Somente a lira e a kithara podiam desafiar seu papel na educação, no teatro, nos festivais e na música da vida cotidiana. ${ }^{13}$

O autor também reforça que o aulos "assume um lugar central na alta cultura grega".

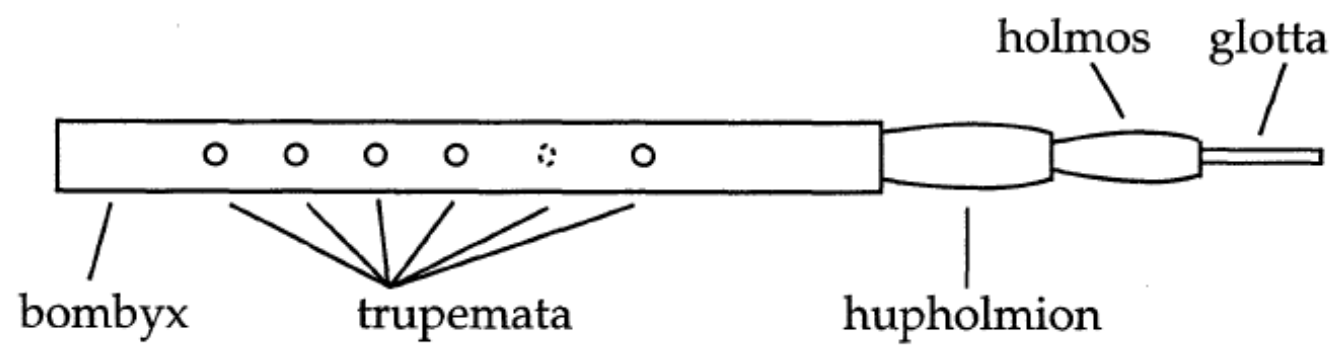

(the dotted circle indicates a trupema on the reverse side)

Fig. 3 - Esquema mostrando as partes de um aulos. Vê-se as regiões da palheta [glotta] e do corpo do instrumento [holmos, hupholmion e bombyx], além dos furos ao longo do tubo [trupemata], sendo cinco à frente e um atrás (MATHIESEN, 1999)

\subsubsection{Preconceitos}

As diferenças tímbricas entre a lira e o aulos e ainda suas funções sociais junto à civilização grega não teriam sido bastantes para motivar o juízo de valor através do qual os dois instrumentos seriam avaliados por diversos pensadores que, frequentemente, exaltariam o instrumento de Apolo e rebaixariam aquele de Mársias.

13 “(...) by the fifth century B.C.E., the aulos had become one of the two or three most important instruments in Greek culture. Only the lyre and the kithara could challenge its role in education, the theatre, the festivals, and the music of daily life." 
Afinal, um olhar sobre o cotidiano musical daquele povo mostra que tanto a lira quanto o aulos desempenhavam funções junto a diversos eventos sociais de não pouca importância, sendo parte fundamental na sua realização. O aulos, antes de ser um instrumento utilizado apenas em ocasiões de baixo mérito, marcava presença em relevantes acontecimentos públicos e formais. Além disso, o gosto pessoal por determinado instrumento e seu timbre não seria, também, suficiente para a fundamentação de uma argumentação a favor ou contra sua utilização. O julgamento de valor da lira e do aulos deve ter sido, portanto, oriundo de um outro tipo de pensamento.

Conhecendo-se a maneira como os gregos prezavam sua cultura e seus costumes em detrimento àqueles de outros povos por eles considerados "bárbaros", é possível supor que o rebaixamento do aulos, desde a elaboração dos mitos que o envolvem até a reprovação de seu uso por parte de alguns, esteja ligado a um enraizado preconceito contra o estrangeiro. Segundo Sachs (1940, p.129), por exemplo, a "divindade nacional [Apolo] opôs a kithara ao aulos do sileno forasteiro [Mársias]" (vale lembrar que Mársias era conhecido como sendo nativo da Frígia).

Mathiesen (1999, p.176-177, tradução nossa) expõe de forma clara essa questão:

\begin{abstract}
Instrumentos de sopro, assim como os de percussão, foram associados particularmente ao culto de Cibele e Dionísio, e sempre vistos com alguma ambivalência na cultura musical Grega como não verdadeiramente "Gregos". Isso é refletido nos vários mitos circundando a descoberta do aulos e da sirynx. Enquanto a invenção da lira é claramente atribuída a Hermes e o instrumento é indissociavelmente ligado a Apolo, a lenda coloca a origem do aulos na Frígia. Uma origem na Ásia Menor naturalmente conecta o aulos com Dionísio porque cultos proeminentes a ele existiam tanto na Frígia como na Trácia. De fato, era comumente presumido pelas antigas autoridades que o deus - e logo, sua música - tinham chegado na Grécia a partir dessas regiões estrangeiras. ${ }^{14}$
\end{abstract}

\footnotetext{
14 "Wind instruments, like the percussion, were associated particularly with the cults of Cybele and Dionysus, and the instruments were always regarded with some ambivalence in Greek musical culture as not truly 'Greek'. This is reflected in the various myths surrounding the discovery of the aulos and the syrinx. While the invention of the lyre is clearly assigned to Hermes and the instrument is inextricably linked to Apollo, legend places the origin of the aulos in Phrygia. An origin in Asia Minor naturally links the aulos with Dionysus because prominent cults of Dionysus existed in both Phrygia and Thrace. Indeed, it was commonly assumed by ancient authorities that the god - and thus his music - had come to Greece from this 'foreign' regions."
} 
O autor ainda complementa a ideia do preconceito contra o aulos argumentando (1999, p.222, tradução nossa) que ele era "visto por alguns [gregos] como um instrumento estrangeiro que introduziu complexidade e virtuosismo incomuns em sua mais venerável tradição musical"15. Certamente, esse citado virtuosismo instrumental foi na época condenado por alguns como vazio, desnecessário e anti-natural. Assim, no próprio mito de Apolo e Mársias, a figura do virtuoso é apresentada de forma negativa, uma vez que teria o virtuosismo do sátiro no aulos sido responsável por sua hybris e causado, mais tarde, sua própria morte.

\title{
3.1.4 Os mitos e os pensadores
}

Inegavelmente, os mitos exerciam forte influência sobre o pensamento grego. Como expõe Cerqueira (2012, p.62)

\begin{abstract}
uma das características do debate intelectual entre os Gregos era recorrer a narrativas míticas, pertencentes a um caldo de cultura comum, para legitimar as opiniões sustentadas ou mesmo para torná-las mais inteligíveis, sob a forma de metáforas ou parábolas. Este é um dos aspectos da relação que o pensamento racional Grego mantinha com a tradição mitológica. $O$ mesmo ocorre na discussão sobre o caráter e valor dos instrumentos, na suposição de uma determinada origem divina, mitológica, da lira ou do aulos, como forma de lhes atribuir funções positivas ou negativas relativamente à cultura hegemônica.
\end{abstract}

Portanto, não causa estranhamento o fato de importantes pensadores como Platão e Aristóteles terem buscado nos mitos motivação para suas ideias. Ambos os filósofos, ao tratarem do uso dos instrumentos musicais na educação e na vida cotidiana, reprimem a utilização do aulos baseando-se nas histórias que o envolvem. Platão, em sua República (399e), banirá de sua cidade o "instrumento do sátiro Mársias", preferindo "a lira simples de Apolo"16. Aristóteles, na Política (VIII, VI, 1341b) afirmará que Atena descartou o aulos não apenas pelo fato do instrumento deformar seu rosto enquanto ela o tocava, mas também porque a deusa, patrona das ciências e

\footnotetext{
15 “(...) viewed by some as a foreign instrument that introduced unwonted complexity and virtuosity into their most venerable musical traditions."

${ }^{16}$ Curiosamente, no mesmo livro (399d), Platão bane de sua cidade a sirynx, a verdadeira "flauta" dos gregos, mas permite que ela esteja presente nos campos, entre os pastores.
} 
das artes, teria percebido que o ato de tocar aquele instrumento não contribuiria em nada para o aperfeiçoamento da inteligência de seu intérprete. Cerqueira (2012, p.63) explica a questão indicando que

o emprego dessas referências míticas por Platão (...) e Aristóteles tem um caráter emblemático uniforme: fundar a rejeição filosófica e pedagógica ao aulos nos motivos que levaram Atena a rechaçá-lo e no simbolismo inerente à vitória de Apolo sobre o sátiro.

\subsubsection{Iconografia e novas interpretações}

Uma vasta iconografia grega, por sorte, sobreviveu ao tempo e chegou aos dias de hoje. Graças a isso, é possível observar os comentados mitos envolvendo Atena, Apolo e Mársias retratados em pinturas e esculturas da época. Uma vez que essas narrativas faziam parte de um repertório mítico muito conhecido pelos gregos é natural que as histórias da criação do aulos e do duelo musical do deus com o sátiro tenham sido muitas vezes representadas na Antiguidade. No entanto, após esse período, demoraria muito tempo para que o tema voltasse a servir de inspiração para criações artísticas.

É no século XV, em pleno Renascimento europeu e seu profundo interesse pelas culturas clássicas antigas, que esses mitos voltam a ser retratados em diversas obras de arte, e em meio a algumas delas percebe-se algo curioso: a substituição das figuras da lira e o aulos por aquelas de outros instrumentos musicais. Isso pode causar certa estranheza, uma vez que sabe-se hoje em dia da importância que os dois citados instrumentos tiveram tanto para a criação dos mitos quanto para a cultura grega em geral. No entanto, é interessante pensar na causa dessas substituições.

Naquele período, a lira e o aulos, tão icônicos para os gregos antigos, já não faziam parte da vida cultural do homem renascentista. Assim, alguns artistas revolveram retratar os mitos através da imagem de instrumentos contemporâneos "equivalentes". Nesses casos, a lira grega é normalmente substituída pela lira da braccio ou ainda pela viola e no lugar do aulos são representados instrumentos de sopro mais comuns na época, como bombardas e charamelas ou até mesmo gaitas-defole. 
De acordo com Winternitz (1979, p.153, tradução nossa), as substituições de instrumentos eram realizadas "por vezes ingenuamente, mas frequentemente também porque um instrumento familiar da vida diária revela seu simbolismo mais diretamente para seu observador"17. E é justamente o antigo simbolismo opondo os dois tipos de instrumento que persevera nas pinturas renascentistas. Provavelmente, os artistas da época não estariam muitos preocupados com a ideia de fazer substituições fiéis aos reais timbres ou aspectos físicos dos instrumentos gregos (vê-se, por exemplo, a lira de cordas pinçadas sendo substituída por instrumentos de cordas friccionadas por arco, com sonoridades muito distintas). De qualquer modo, mesmo através das trocas de instrumentos, a ideia da oposição entre cordas e sopros permanece, o que faz com que a essência dos mitos seja de alguma forma mantida.

A dicotomia entre lira e aulos é uma das primeiras e mais significativas questões envolvendo os aspectos simbólicos dos instrumentos musicais e, apesar de antiquíssima, é persistente ao longo da história, alcançando mesmo, de algum modo, a atualidade. Como anuncia Winternitz (1979, p.153, tradução nossa), essa conotação simbólica dos instrumentos

\begin{abstract}
não só sobreviveu aos deuses antigos como também persistiu através das eras. Ela ainda está firmemente integrada a subcorrentes, como por exemplo a música folclórica de civilizações contemporâneas. E isso é verdade especialmente para os instrumentos orgiásticos, os sopros de palheta, que preservaram seu timbre excitante e caráter simbólico desde o aulos grego e a tíbia romana, a gaita-de-foles medieval e o platerspiel, a charamela da Renascença e a cornamusa e musette do Barroco e Rococó até o saxofone dos nossos dias. ${ }^{18}$
\end{abstract}

De certa forma, o duelo entre Apolo e Mársias nunca terminou.

\footnotetext{
17 "sometimes naively, but often also because a familiar instrument from daily life reveals its symbolism more directly to the beholder."

18 "not only outlived the ancient gods but persisted down through the ages. It is still firmly embedded in the undercurrents, for instance in the folk music of contemporary civilizations. And this is true especially of the orgiastic instruments, the reed pipes, which have preserved their exciting timbre and symbolic character from the Greek aulos and Roman tibia, the medieaval bagpipe and platerspiel, the shawm of the Renaissance, and the cornemuse and musette of the Baroque and Rococo, to the saxophone of our day."
} 


\subsection{Instrumentos musicais no Iconologia, de Cesare Ripa}

Iconologia, de Cesare Ripa, foi pela primeira vez publicado em 1593, mais de cinquenta anos após Emblemata de Alciato ter aberto caminho para o sucesso dos livros de emblemas. A obra de Ripa surge, portanto, num momento quando as publicações do gênero já são diversas e populares. No entanto, em meio a essa quantidade de obras de caráter similar, Iconologia viria a se destacar por apresentar aspectos que o diferenciavam dos outros livros de emblemas. Enquanto a maioria desses livros acabam por propor ou reforçar uma série de "enigmas" que só poderiam ser desvendados por iniciados, a obra de Ripa possui caráter didático, podendo servir como um tipo de manual de consulta a diferentes artistas que adentrassem o universo das alegorias.

O título do livro, em sua ampla extensão, define o caráter da publicação: “Iconologia ou Descrição das imagens universais escavadas da Antiguidade e de outros lugares por Cesare Ripa, perusiano. Obra não menos útil que necessária a Poetas, Pintores \& Escultores, para representar as virtudes, vícios, afetos e paixões humanas"19. Dessa forma, o trabalho tem como principal objetivo enumerar e descrever uma série de figuras alegóricas, anunciando a maneira correta de representá-las e interpretá-las.

A necessidade do livro de Ripa dá-se em meio ao vasto universo alegórico de lugares-comuns tão importantes à arte retórica de sua época e dos séculos seguintes. Aos artistas era preciso um extenso conhecimento de um vocabulário específico que poderia, ou ainda deveria, ser utilizado nas obras de arte e, assim, o Iconologia surge como uma fonte de estudo, compreensão e inspiração no uso das alegorias. Grieco

\footnotetext{
19 “'Iconologia overo descrittione dell'imagini universali cavate dall'antichita et da altri luoghe da Cesare Ripa Perugino. Opera non meno utile, che necessaria à Poeti, Pittore \& Scultori, per rappresentare le virtù, vitij, affetti, \& passioni humane.' Curiosamente, publicações posteriores do Iconologia trazem em seu título menções a uma maior quantidade de artistas de diferentes áreas que poderiam encontrar no livro as informações necessárias às suas representações, sugerindo à obra uma ainda maior abrangência em meio às artes. Enquanto que, como visto, a primeira edição do Iconologia (datada de 1593) o indica em seu título a poetas, pintores e escultores, a edição italiana de 1625 sugere o livro como útil também a oradores, pregadores, desenhistas e "todos os estudiosos"; a edição francesa de 1637 acrescenta à lista engenheiros, autores de medalhas, divisas, ballets e poemas dramáticos e a inglesa de 1709 sugereo também a "todos os amantes da engenhosidade". Nota-se que a sugestão de sua consulta para a concepção de ballets aproxima o conteúdo do livro à atividade musical.
} 
(2003, p.89) considera ainda o Iconologia como necessário num momento em que o

público leitor poderia encontrar-se perdido em meio a um mundo simbólico:

A cultura do livro de emblema cresce e multiplica de tal modo, e tantos livros de emblema são criados, traduzidos e publicados, que em determinado momento os leitores europeus estão já perdidos numa inflação de símbolos, hieróglifos, marcas secretas, e códigos herméticos de todo tipo. Nesse instante, surge um livro de emblemas que é diferente, mas que também é absolutamente necessário: um livro com as "chaves" para todos os milhares de emblemas que se multiplicam, para as infinitas simbologias que proliferavam (...) Com tanto simbolismo, o discurso visual, sobrecarregado, ficou afetado. Vai ser preciso cortar mais um nó górdio na história da visualidade, e essa tarefa caberá a (...) Cesare Ripa, autor da Iconologia.

Ripa, assim como outros humanistas do Renascimento, foi um estudioso da Antiguidade Clássica, cujo legado histórico e cultural é extremamente presente em seus escritos, mesclando-se também ao conhecimento oriundo de sua época. Segundo Zimmermann (1995, p.17, tradução nossa), em Iconologia,

Ripa queria oferecer não apenas um acúmulo de imagens inúteis, mas uma descrição e explanação de figuras universais que eram acessíveis a qualquer homem educado. E colocou que as havia encontrado na antiguidade bem como em outros lugares. Algumas delas, a propósito, ele mesmo as criou quando uma figura alegórica era necessária porém infelizmente faltante nas fontes clássicas. ${ }^{20} 21$

Ainda sobre as fontes de pesquisa de Ripa, o autor continua:

(...) Ripa, como um todo tentou alcançar aquilo que considerava as origens definitivas da tradição simbólica Europeia comum: a antiguidade Grega e Romana e a Bíblia. A escultura Romana e moedas imperiais provaram-se um tesouro especialmente inesgotável. $A$ isso devemos adicionar duas outras fontes: (1) O conhecimento derivado da antiga, i.e, zoologia fabulosa, herdado dos Phisyologos e Bestiarius às zoografias do século XVI ao estilo do Historia animalium de Conrad Gesner. (2) A Hieroglyphica de Horapolo - um dos mais estranhos e fantásticos livros sobre o simbolismo de animais,

\footnotetext{
20 "Ripa wanted to offer not just a heap of somewhat broken images but a description and explanation of universal pictures which were accessible to any educated man. And he pointed out that he had found them in antiquity as well as in other places. Some, by the way, he made up for himself when an allegorical figure was considered necessary but unfortunately missing from classical sources."

${ }^{21}$ A segunda edição italiana da obra, de 1603, traz em seu título a informação de que as imagens descritas por Ripa eram "cavadas da antiguidade e de invenção própria".
} 
plantas e objetos que chegou até nós do final da antiguidade. Ripa usou esse conto-de-fadas hieroglífico numa torturante forma expandida com explanações, a Hieroglyphica, sive de sacris Aegyptiorum literis commentarii (1556). (1995, p.18, tradução nossa). ${ }^{22}$

Como visto, Iconologia possui claramente uma forte ligação com aspectos alegóricos. Hansen (2006, p.181), ao comentar o livro, indica que ali "pela primeira vez se emprega o termo 'iconologia' para descrever e interpretar obras de gênero emblemático relacionadas à alegoria" e mencionando a forma como o autor a trata no livro, explica:

\begin{abstract}
Ripa escreve, no 'Proêmio' do texto, que analisará 'imagens que são feitas para significar coisa diferente da que é dada a ver'. A proposta é familiar ao leitor: propõe a alegoria retomando Quintiliano e o costume da retórica antiga. Não só, porém, uma vez que também se ocupa da egiptomania dos livros de emblemas do século XVI, sintetizados na obra de Andrea Alciato, Emblemata (1531), que dá continuidade ao neoplatonismo florentino.
\end{abstract}

O livro de Ripa alcançou enorme sucesso por toda a Europa e tanto o original em italiano como uma série de traduções em francês, inglês, alemão e holandês foram publicadas ao longo dos dois séculos seguintes. Zimmermann (1995, p.18) afirma que o livro alcançou durante esse período um alto nível de popularidade e respeito ao ponto do estudo do sistemático compêndio de figuras alegóricas ser "um dever para o artista criativo, o conhecedor apreciativo e o crítico e o acadêmico que se prezassem". A respeito disso, Panofsky (GRIECO, 2003, p.89) comentará o Iconologia como

aquela 'summa' da iconografia que, abeberando-se em fontes tanto clássicas e medievais como contemporâneas, foi, justamente, chamada de 'a chave das alegorias dos séculos XVII e XVIII', e explorada por artistas e poetas tão ilustres quanto Bernini, Poussin, Vermeer e Milton (...).

\footnotetext{
22 "Ripa on the whole tried to reach back to what he considered the definitive origins of the common European symbolic tradition: Greek and Roman antiquity, and the Bible. An especially inexhaustible treasure-trove proved to be Roman sculpture and imperial coins. To this we must add two further sources: (1) The knowledge derived from ancient, i.e. fabulous zoology, handed down through the Physiologos and the Bestiarius to the 16th century zoographies in the style of Conrad Gesner's Historia animalium. (2) The Hieroglyphica of Horapollo - one of the strangest and most fanciful books on the symbolism of animals, plants and objects to have reached us from very late antiquity. Ripa used this hieroglyphical fairy-tale in a nightmarish expanded form cum explanations, the Hieroglyphica, sive de sacris Aegyptiorum literis commentarii (1556)."
} 
A primeira edição do livro foi publicada sem ilustrações, contendo apenas as descrições textuais do autor. No entanto, a segunda, datada de 1603, já contém uma série de imagens em xilogravuras. A partir de então, as edições seguintes da obra seriam todas ilustradas.

Ao longo do tempo, as diversas publicações do livro mostrar-se-iam significantemente diferentes, distinguindo-se umas das outras tanto em relação à redação quanto às figuras. O texto original de Ripa é, por vezes, modificado, adaptado, ampliado ou simplificado e as ilustrações, realizadas por diferentes artistas, também apresentam diferenças. No entanto, o conteúdo essencial proposto pelo autor é sempre mantido, em ambas as partes, permitindo a permanência, ao longo dos séculos, das características da alegoria representada.

As figuras alegóricas apresentadas e explanadas por Ripa abrangem um universo de temáticas variadas. O autor não só tratará dos já citados afetos, virtudes, paixões e vícios humanos, mas também de outros aspectos como os temperamentos, os elementos, as estações do ano, figuras mitológicas, ciências e conhecimentos diversos etc., ou seja, de tudo aquilo que poderia vir a ser artisticamente representado de forma alegórica.

A representação das figuras é retoricamente pensada e regulamentada. Em sua elaboração, como escreve Hansen (2006, p.185),

\begin{abstract}
retornam, pois, as categorias da Retórica antiga, principalmente a de conveniência, adequação, ou decoro: para coisas do conhecimento, imagens de coisas elevadas; para coisas elevadas moralmente, coisas esplêndidas; para coisas censuráveis, imagens de coisas vis etc., observando-se a transposição, para a pintura, da distribuição retórica dos estilos sublime, médio e humilde. Se as prescrições são obedecidas, o efeito obtido é o seguinte: as imagens pictóricas dos conceitos produzem, em quem as vê, outros conceitos.
\end{abstract}

A partir dos importantes preceitos retóricos, Ripa descreve suas figuras alegóricas com minúcia, utilizando-se para isso de uma série de diferentes coisas como pessoas, animais, cores, vestimenta e diversos tipos de objetos, entre os quais encontram-se instrumentos musicais. 
Ao que aqui interessa, percebe-se a importância do Iconologia como fonte de informações sobre os aspectos alegóricos presentes nos instrumentos musicais. Sua utilização por Ripa, assim como praticamente tudo o que o autor aborda em suas descrições, é quase toda fundamentada em tradições que formam juntas um conceito através do qual o instrumento será visto, representado e utilizado. Numa alegoria de Ripa, nenhum elemento é supérfluo ou encontra-se ali por acaso; antes, ele mostra-se essencial para a composição de um todo maior, a alegoria em si. Logo, podemos pensar que em Ripa várias alegorias juntam-se para formar uma só. Nesse ponto de vista, um instrumento musical é ali uma pequena alegoria que representa algo que transpassa seu significado de mero produtor de sons e eleva seu potencial simbólico, ajudando a compor a essência da figura alegórica então descrita.

O fato de Ripa basear-se no conhecimento clássico, medieval e também contemporâneo a si para elaborar suas figuras mostra que, provavelmente, o modo alegórico através do qual os instrumentos são representados em sua publicação seja o retrato de uma visão acumulada e mantida por muito tempo que se faz presente ainda na época quando o livro foi escrito e que, devido à sua manutenção em edições muito posteriores do mesmo, mostra-se ainda ativa, em maior ou menor grau, tempos depois. Assim, podemos entender o uso alegórico de um instrumento musical no Iconologia como a reprodução do modo pelo qual o mesmo foi simbolicamente vislumbrado desde a Antiguidade até o Renascimento, ao menos. No entanto, é válido lembrar que essa visão pode ter sido mais claramente contemplada e fortemente seguida nos campos das artes plásticas e da poesia. No meio musical teórico e prático, isso poderia apresentar variações.

No Iconologia é possível encontrar citações e representações de uma quantidade variada de instrumentos musicais, de diversos tipos: sopros de madeira e metal, cordas dedilhadas e friccionadas e percussão. Essa variedade permite uma compreensão direta ou indireta de aspectos simbólicos relacionados a cada tipo de instrumento, de forma geral ou específica.

Nesse contexto, buscar-se-á aqui realizar uma breve análise da maneira como o livro (ou ainda, os livros) emprega um instrumento musical como parte das alegorias, ressaltando-se algumas de suas características simbólicas e não conectadas à música que executam (ou seja, aquelas detidas pelos instrumentos em si ou a eles atribuídas). 
Vale ressaltar que à época de Ripa a terminologia de designação dos instrumentos musicais não era muito padronizada, sendo que um mesmo instrumento podia ser conhecido e citado por nomes diferentes (BAINES, 1991, p.237). Isso pode trazer, por vezes, certa dificuldade no reconhecimento do real instrumento mencionado pelos autores da época, principalmente em relação àqueles da antiguidade, que na Renascença já não eram mais tão conhecidos e tocados. Além disso, percebe-se claramente que Ripa, seus tradutores, adaptadores e ilustradores não tinham fortes preocupações organológicas ao mencionar e representar os instrumentos musicais no Iconologia. Afinal, essa não é uma publicação que trata especificamente de música. Mesmo assim, a obra faz-se importante por ter influenciado gerações de artistas e ajudado a manter viva uma tradição, ou ainda uma soma de tradições.

Nessa análise, baseada em cinco diferentes edições da obra (publicações em italiano de 1593, 1603 e 1625, uma edição francesa de 1637 e uma inglesa de 1709), levar-se-á em conta a época de Ripa e seus possíveis pontos de vista em relação aos instrumentos musicais que ele pode ter vindo a conhecer contemporaneamente ou através de seus estudos históricos. Como a obra original passou por várias modificações ao longo do tempo, tenta-se aqui buscar o maior número de informações possível nas mencionadas duas primeiras edições italianas que, além de conter o texto original do autor, também foram publicadas muito provavelmente sob seu cuidado, podendo ser, assim, mais fiéis às suas ideias e pensamentos. Apesar disso, é válido lembrar que um estudo do conteúdo de várias versões do Iconologia, contando com suas semelhanças e diferenças, traz à tona não só a visão de Ripa, mas também a de outros autores que trabalharam sobre seu texto original. Nesse sentido, é interessante também notar como muitos conceitos, apesar de por vezes modificados, mantêm em sua essência as ideias de Ripa, mostrando assim a força e a manutenção da tradição mesmo com o passar do tempo. 


\subsubsection{O emprego dos instrumentos nas alegorias}

Flauta e tíbia:

Descrevendo a alegoria que representa a "Adulação", Ripa redige o seguinte texto:

Mulher, que toca a tíbia ou a flauta, com um cervo, que dorme a seus pés: assim a descreve Oro Apolline, e escrevem alguns que o cervo, de sua natureza atraído pelo som da flauta, quase se esquece de si mesmo, deixando por ela levar-se. Conforme isso eis a imagem, na qual se representa a doçura das palavras com a melodia do som e a natureza daqueles que se deixam adular com o infeliz instinto natural do cervo que mostra, ainda, que é tímido e de mente fraca, que voluntariamente dá ouvidos aos aduladores. (RIPA, 1593, p.4, tradução nossa) $)^{23}$

Na primeira edição da obra constando de ilustrações (1603), a Adulação, seguindo a descrição anterior, fica assim representada:

23 "DONNA, che suoni la Tibia, overo il Flauto, con un Cervo, che le stia dormendo vicino a' piedi; così la depinge Oro Appolline, \& scrivono alcuni, che il Cervo di sua natura, allettato dal suono del Flauto, quasi si dimentica di se stesso, \& si lascia pigliare. In conformatione di ciò è la presente imagine, nella quale si dichiara la dolcezza delle parole con la melodia del suono, \& la natura di chi volentieri si sente adulare con l'infelice naturale instinto del Cervo, il quale mostra ancora, che è timido, \& d'animo debole chi volentieri porge gl'orecchi à gli Adulatori." 


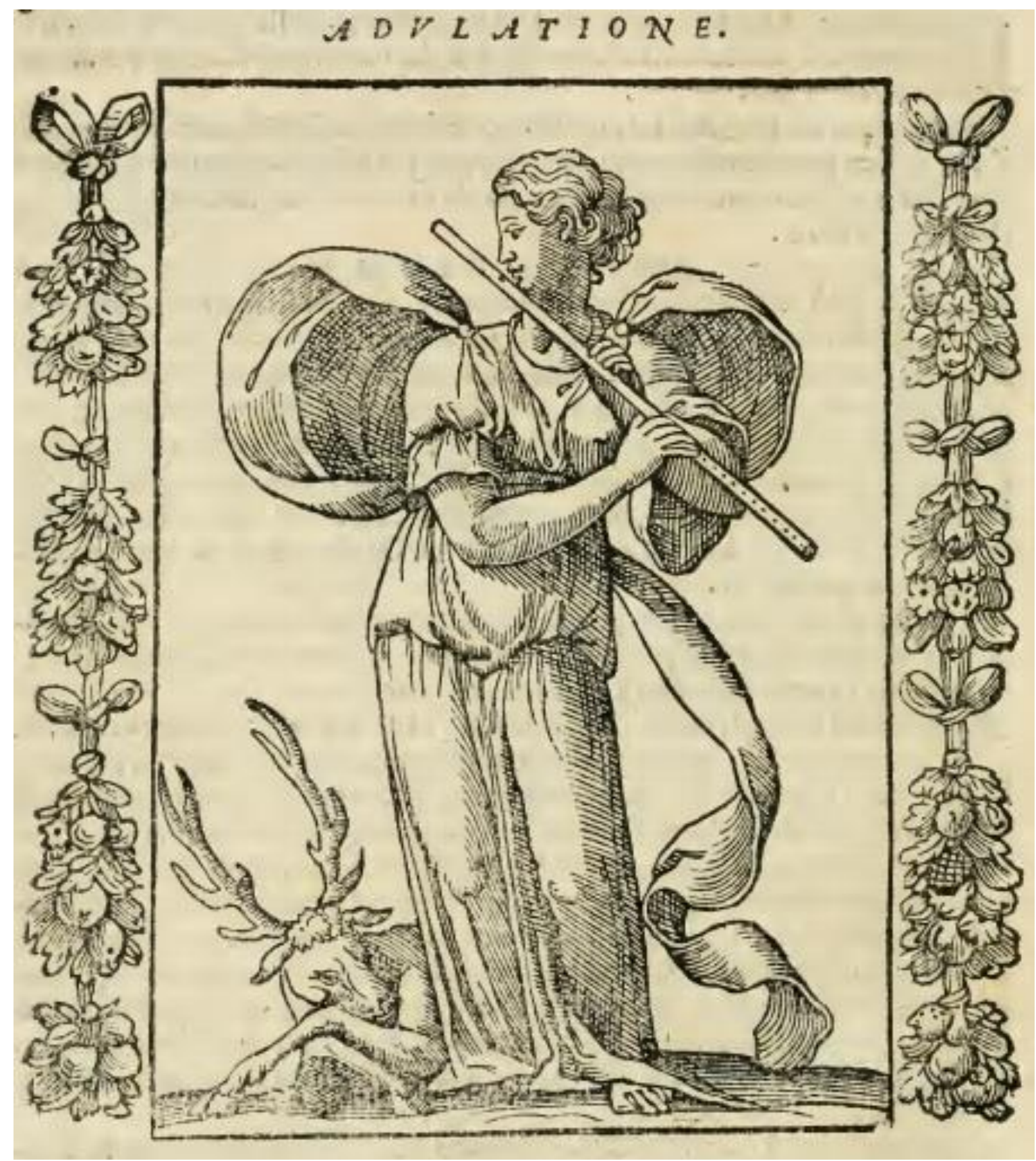

Fig. 4 - Alegoria da Adulação (RIPA, 1603)

No entanto, em edições posteriores da obra, na qual a ilustração dessa figura alegórica se fará, com frequência, presente, sua representação será um pouco diferente: 


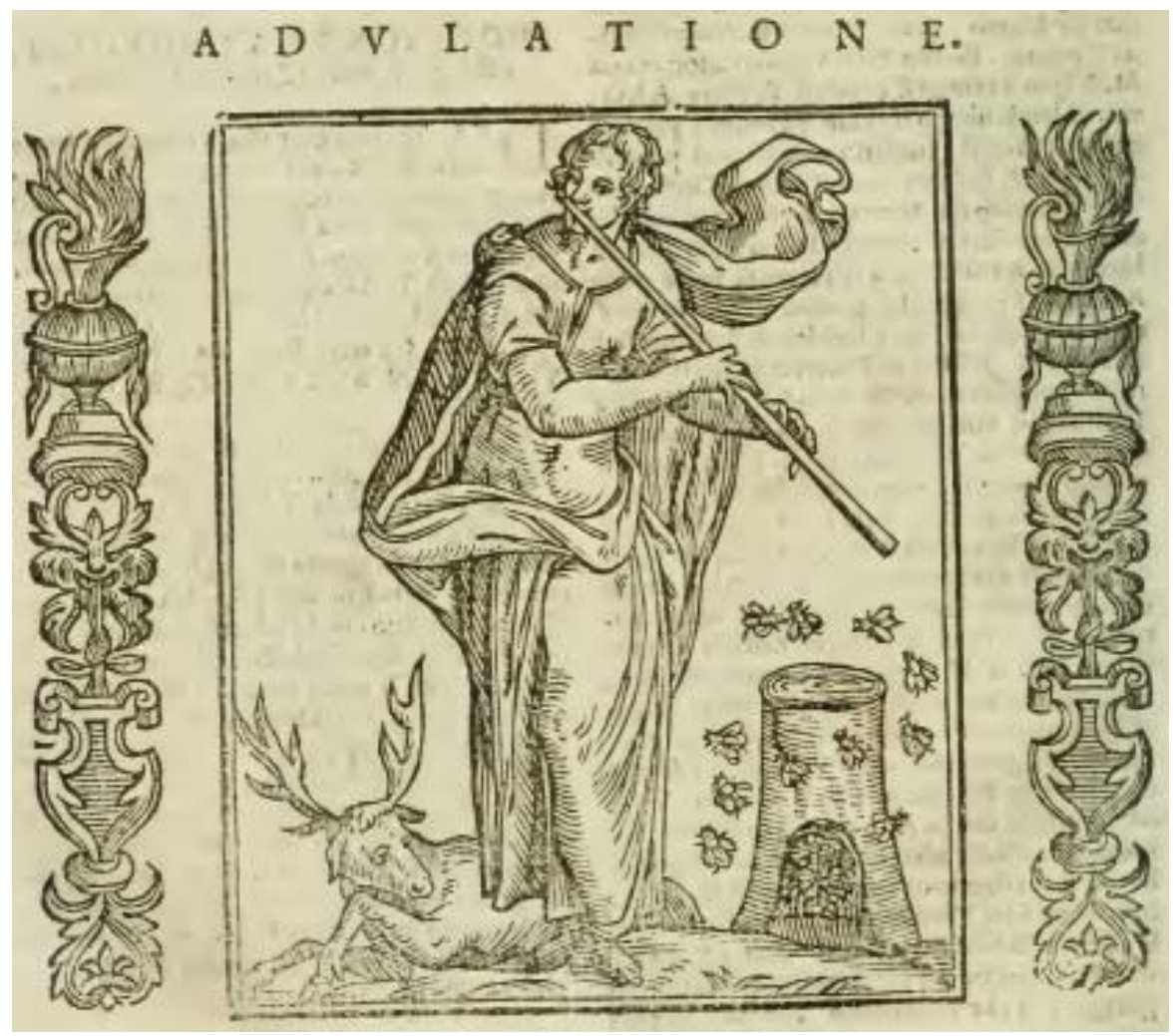

Fig. 5 - Alegoria da Adulação (RIPA, 1625)

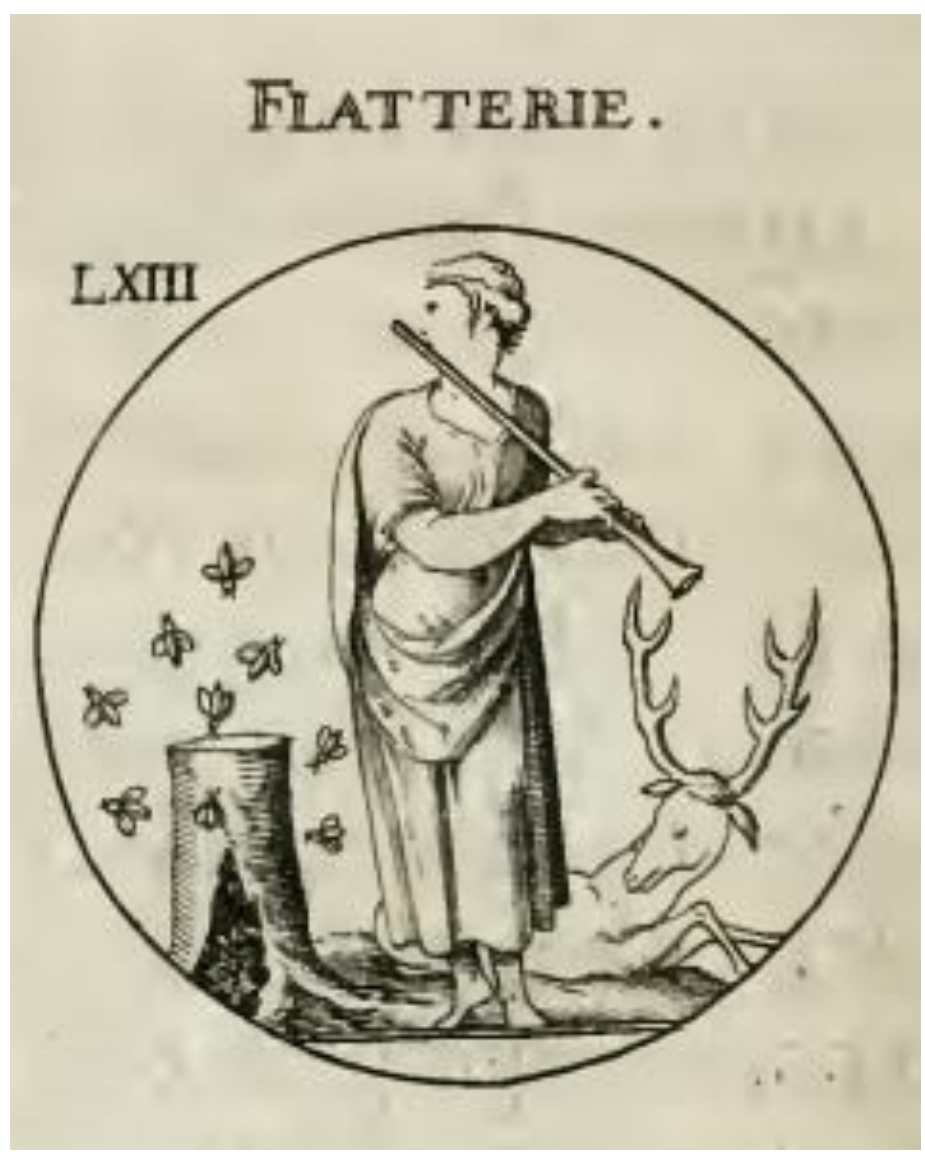

Fig. 6 - Alegoria da Adulação (RIPA, 1637) 


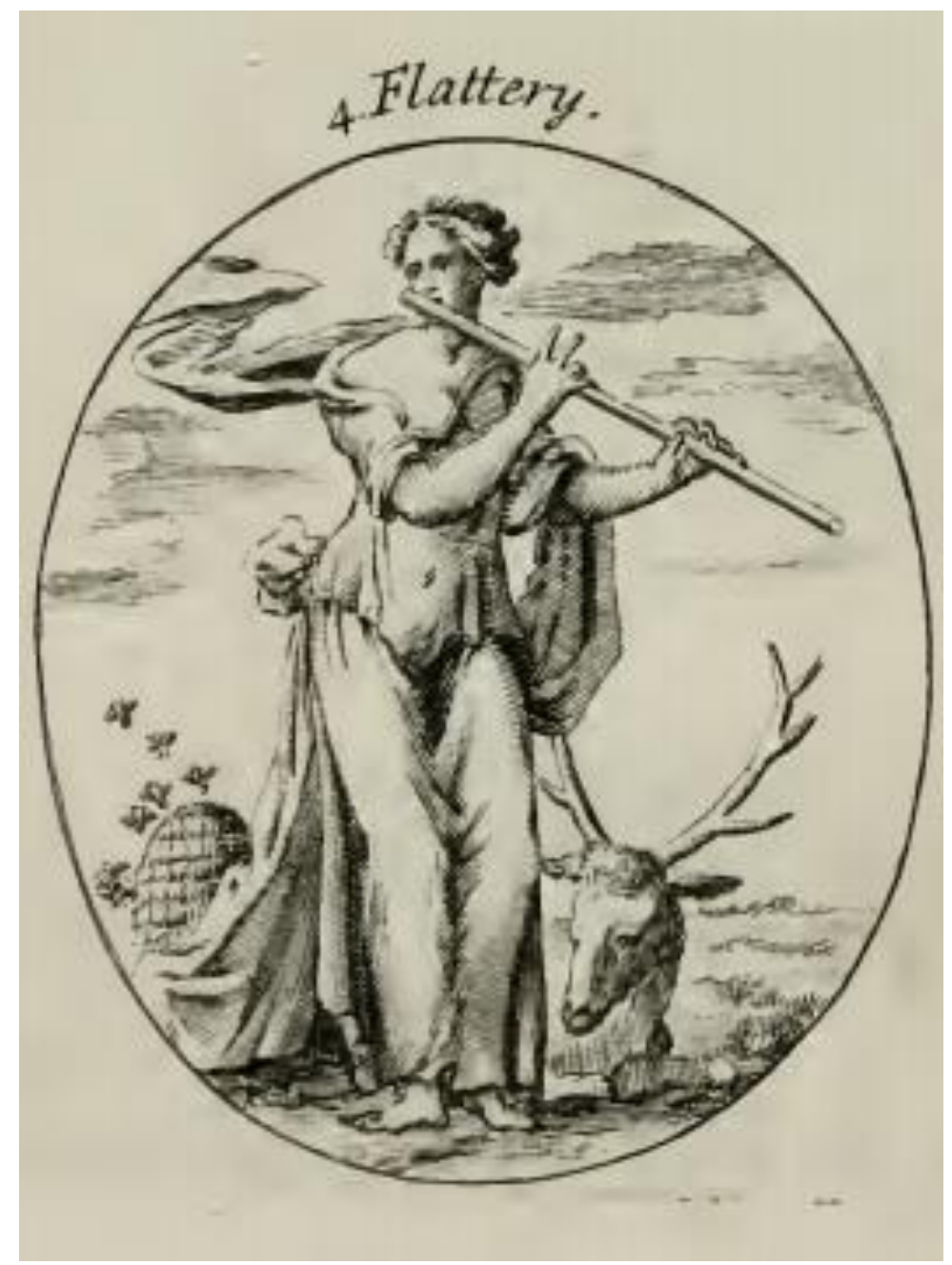

Fig. 7 - Alegoria da Adulação (RIPA, 1709)

Na três figuras anteriores, provenientes de edições da obra datadas de 1625, 1637 e 1709, respectivamente, nota-se que além dos elementos contidos na citada descrição de Ripa, há também a presença de uma colmeia sobre a qual voam abelhas. Essa adição à ilustração ocorre devido à junção de outra descrição da figura pelo autor.

Por vezes, Ripa descreve uma figura alegórica de diferentes maneiras através das quais a mesma poderia vir a ser representada ou interpretada, dando a seus leitores mais de uma visão da mesma alegoria. Nas diversas publicações da obra, essa diversidade de descrições foram por vezes suprimidas ou de algum modo mescladas. Esse é o caso da figura da Adulação. Já em sua primeira edição o Iconologia contém uma outra descrição da alegoria, na qual lê-se (1593, p.4, tradução nossa): “Mulher com duas faces: uma de jovem bela e outra de velha macilenta. De suas mãos saem 
muitas abelhas, que voam por toda parte $(\ldots)^{\prime 24}$. A presença das abelhas é depois explicada da seguinte forma:

As abelhas, segundo Eucherio, são o próprio simulacro do Adulador, porque na boca têm o mel e no oculto têm um acúleo pungente, com o qual ferem tantas vezes o homem que não vê. (RIPA, 1593, p.5, tradução nossa) ${ }^{25}$

Essa característica, presente numa segunda descrição, deve ter sido considerada relevante, e portanto, mesclada e fixada à primeira imagem mostrada dessa alegoria.

Ripa indica como instrumento musical da Adulação uma tíbia ou flauta ("Ia tibia overo il flauto"). O autor parece, assim, empregar dois termos diferentes (um latino clássico e outro em vernáculo) para designar um mesmo instrumento. Essa questão fica ainda mais clara em um dos diversos índices presentes na edição de 1625 do Iconologia: em uma listagem dos vários objetos que aparecem compondo as muitas alegorias da publicação, intitulada Tavola d'Ordigni diversi, vê-se os termos listados novamente juntos, "Tibia, ò flauto" (ainda que flauto apareça ali também separadamente).

Atualmente, o termo tíbia normalmente é usado para designar a versão Romana do aulos Grego (como cita Winternitz, 1979, p.150), que seria um instrumento de palheta, muito diferente, portanto, de uma flauta. No entanto, a já mencionada falta de padronização em relação aos termos que designavam os instrumentos musicais existente na época, somada ao desconhecimento dos então obsoletos instrumentos da Antiguidade, coloca dúvidas a respeito dos objetos que os termos estariam de fato nomeando. Aliás, ainda no século XVIII nota-se certa confusão em relação a terminologias. Ghirardini (2008, p.174) explica que os estudiosos dos séculos XVII e XVIII não possuíam um método moderno de análise de artefatos acústicos e ignoravam abordagens etnomusicológicas. Assim, com base em citações literárias ou

\footnotetext{
24 "DONNA, con due faccie, l'una di giovane bella, \& I'altra di vecchia macilenta, dalle mani le escono molte Api, che volino in diverse parti."

25 "L'api, secondo Eucherio, sono proprio simulacro dell'Adulatore, perche nella bocca portano il mele, \& nell'occulto tengono il pungente aculeo, col quale feriscono molte volte l'huomo, che non se ne avvede."
} 
representações em fontes iconográficas, tibiae eram normalmente compreendidas como flautas ou trompetes.

Entretanto, a pesquisadora também cita que "alguns autores, já no século XVII, acreditavam que tibiae eram instrumentos de palheta comparáveis às charamelas". $\mathrm{Na}$ verdade, essa crença existia já no século XV.

Nota-se, portanto, que o termo tíbia seria um tanto quanto genérico nos tempos de Ripa, podendo referir-se a vários instrumentos de sopro.

O autor não utiliza os dois termos sempre em conjunto, sendo que além da Adulação, certas alegorias são detentoras de tíbias e outras de flautas, separadamente. As gravuras que as representam, sendo pouco minuciosas, parecem mostrar instrumentos diferentes. Os desenhos presentes nas edições mais antigas do livro, nas quais o termo tibia não é substituído por outros, poderiam não só sugerir a representação de flautas transversais e doces, mas também de charamelas, por exemplo. Como afirmam Anderson e McKinnon (TIBIA, 2001), o teórico Johannes Tinctoris, em seu De inventione et usum musicae, de cerca de 1487, utiliza o termo tíbia para referir-se à charamela. De fato, no livro III de seu trabalho, Tinctoris escreve: “(...) hoje em dia, a tíbia, chamada de celimela, possui sete furos." (BAINES, 1950, p.20, tradução nossa) ${ }^{26}$. Portanto, para Ripa e seus contemporâneos, assim como para Tinctoris, o termo tíbia também poderia indicar o antecessor dos oboés do século XVII.

De qualquer modo, dentro da alegoria da Adulação o instrumento tem a função de representar com seus doces sons as palavras do adulador, que encantam, distraem ou ainda hipnotizam aqueles que as ouvem. Ripa descreve com clareza uma "doçura" proveniente da sonoridade do instrumento e esse aspecto não dificilmente relaciona-o diretamente às flautas (doce ou transversal), cuja figura e sonoridade estiveram com frequência conectadas ao universo pastoral e amoroso e, consequentemente, à calma, à delicadeza e à beleza mesclada à simplicidade (GRISCOM, 1994; POWELL, 2002).

À época das primeiras edições do Iconologia, a flauta doce desfrutava de popularidade similar à flauta transversal e, uma vez que ali o termo italiano flauto poderia ser usado para designar ambos os instrumentos, não é possível excluir-se o fato do autor poder ter originalmente se referido à flauta doce, da qual é também possível dizer-se da "doçura" do som. Contudo, nas figuras do livro, desde sua primeira

26 “(...) nowadays, the tibia called celimela has seven holes." 
edição ilustrada, nota-se a presença constante da flauta tocada lateralmente, assim como os traversos renascentistas que Ripa devia conhecer.

Apenas na terceira ilustração vê-se um instrumento que parece ter uma campana, como as charamelas, mas que também é tocado lateralmente, o que sugere um provável descuido do ilustrador ao querer desenhar uma flauta transversal. Portanto, ela parece ter sido compreendida como o instrumento mais indicado para essa representação alegórica ${ }^{27}$. Aliás, o termo tíbia foi por vezes suprimido da descrição da Adulação em algumas edições mais tardias do livro.

A flauta é também citada em uma das descrições feitas por Ripa para a alegoria da "Indústria":

Na imagem de Mercúrio, que na mão direita tem um Caduceu e na esquerda uma Flauta, os Antigos imaginaram as duas causas que geram a Indústria, que são o que é útil por si e o que é um deleite para outros; aquela se mostra no Caduceu com o qual, fingem os Poetas, Mercúrio despertava os homens já mortos; essa, com a Flauta, instrumento feito para adocicar as almas e minimizar as moléstias. (RIPA, 1593, p.131, tradução nossa) $)^{28}$

Aqui a flauta é mais uma vez utilizada devido à doçura de sua sonoridade, que seria capaz de acalmar e curar os seres. Nessa descrição, Ripa não menciona o termo tíbia.

A alegoria representando as "Letras" também é formada com a presença do "doce" instrumento:

\footnotetext{
${ }^{27}$ Na descrição da representação da Adulação feita por Oro Apolline Niliaco, citado por Ripa como fonte de informação para a alegoria, o cervo aparece, curiosamente, acompanhado por uma trombetta (segundo uma tradução italiana do livro feita por Pietro Vasolli e publicada em 1547, a qual Ripa certamente deveria conhecer). Tal questão é instigante pelo fato de que, já naquela época, a trombeta era um instrumento de sonoridade forte e pungente, normalmente associada à música solene e militar e muito utilizada ao ar livre. Imaginar que o cervo seria "encantado" e levado ao sono pelo som de um instrumento como esse é no mínimo estranho. Portanto, se Ripa teve acesso a essa tradução italiana, utilizando-a como base para sua descrição no Iconologia, a decisão em substituir a trombeta por uma tíbia ou flauta mostra-se bastante coerente.

28 "NELL'imagine di Mercurio, che nella destra tiene il Caduceo, \& con la sinistra un Flauto gli antichi figurarono le due cagioni, che generano l'industria, cioè l'utile per sé, \& il diletto per altri, quello si mostra nel Caduceo co'l quale fingono i Poeti, che Mercurio suscitasse gli huomini già morti, questo, co'l Flauto, istromento atto per addolcire gli animi, \& sminuir le molestie."
} 
Mulher vestida com hábito honesto e gentil, que com a mão direita segura um livro e com a esquerda duas flautas, para significar conceitos e palavras, estas como deleitosas, aqueles como honrados. (RIPA, 1603, p.290) ${ }^{29}$

Novamente, a flauta é utilizada na descrição alegórica por ser considerado um instrumento capaz de encantar e dar prazer a seus ouvintes. Além disso, é possível pensar aqui numa relação do instrumento musical com a construção de um discurso literário e sua eloquência, já que diz-se das flautas como representantes das ideias honradas que o geram (conceitos) e dos agentes deleitosos que dão-lhe vida e concretizam-no (palavras).

Como tanto a figura da Indústria como a das Letras não são seguidas de ilustração, não é possível saber se o autor teria pensado na flauta doce ou transversal no desenvolvimento desses conceitos.

O termo tíbia presente na descrição original de Ripa para a Adulação é citado também outras vezes no Iconologia. Retoma-se, então, a questão problemática envolvendo a genericidade do termo e, nos casos em que há uma gravura, a falta de detalhamento ou correção da representação gráfica do instrumento, que impedem a certeza de sua definição. Ela figura, por exemplo, na alegoria para a "Sabedoria humana", onde se faz presente representando os louvores a si mesmo (ao perigo dos quais deve estar alerta o homem sábio). A edição de 1625 mostra a seguinte gravura:

29 "DONNA, vestita d'honesto, e gentil habito, che con la destra mano tiene un libro, e con la sinistra due flauti, per significare concetti, e parole, queste come dilettevoli, quelle come honorabili." 


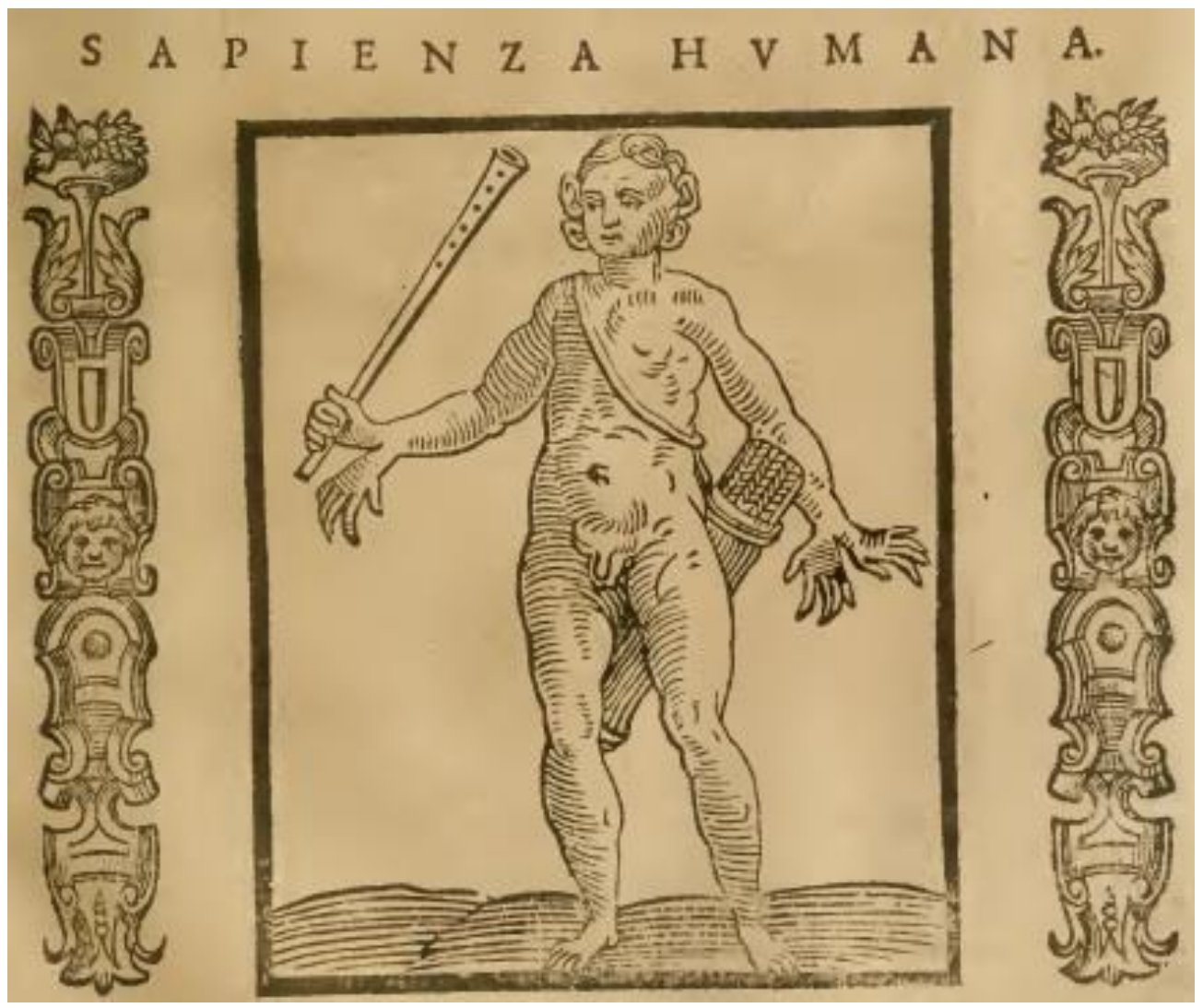

Fig. 8 - Alegoria da Sabedoria Humana (RIPA, 1625)

O instrumento ilustrado assemelha-se mais a uma charamela, com sua provável campana e furos ao longo do tubo.

Na edição inglesa de 1709, tanto texto como ilustração que definem a alegoria descartam o termo tíbia, substituindo-o por um instrumento bem conhecidos no início do século XVIII, a flauta doce (recorder).

Numa das descrições da "Comédia" (sem ilustração) presente já na edição de 1593, Ripa explana:

Mulher, de idade madura, de aspecto nobre, em mãos terá a Tíbia, aos pés, tamancos. Em seu penteado haverá muitas ondas e um grande emaranhado de nós, com o este motivo: Descrevoi o comportamento humano. (RIPA, 1593$, p.46, tradução nossa) $)^{30}$

30 "DONNA, di età matura, d'aspetto nobile, in mano terrà la Tibia, in piedi i zoccoli, nell'acconciatura della testa vi saranno molti travolgimenti, \& con grande intrigo di nodi, con questo motto, Describo mores hominum." 
Ripa não explica o porquê do instrumento fazer parte dessa alegoria. De qualquer modo, seria possível supor uma conexão do mesmo com representações teatrais, talvez por um tradicional uso nesse tipo de evento, o que faria direta ligação com outra descrição da "Comédia" feita pelo autor. Ali, Ripa a descreve como uma mulher cigana que, curiosamente, toca um corneto. Nessa que é sua única menção no Iconologia, o instrumento que gozou de grande popularidade na Europa dos séculos XVI e XVII, é citado por ter sido, segundo Ripa, empregado nas Comédias dos antigos, representando, na alegoria, a harmonia.

Como visto, os termos tibia e flauto se confundem nas publicações de Ripa. Se na alegoria da Adulação parece claro que o autor utilizou ambos para se referir a um mesmo instrumento (uma flauta), em outros momentos não é possível afirmar que Ripa não possa ter pensado em tibia de forma genérica e imaginado outros instrumentos. A variedade de significações alegóricas que tibia e flauto tomam ao longo do livro, somada à confusão por vezes causada pelas ilustrações de instrumentos sem definição, deixam dúvidas a esse respeito.

Flauta de Pã:

A flauta de Pã é designada pelo termo fistula no texto original de Ripa. Apesar desse termo também ter aplicação genérica naquele período, ele certamente faz referência, ali, a tal instrumento, como fica claro a partir de sua descrição, de sua clássica associação a Pã e também das gravuras que o representam. A partir da edição de 1603 do Iconologia, esse tipo de flauta é encontrado junto à alegoria de "Mundo", "como pintado por Bocaccio no primeiro livro da Genealogia dos deuses" (RIPA, 1603, p.330, tradução nossa) $)^{31}$.

O Mundo é representado pelo semi-deus Pã, que é descrito em sua tradicional figura com dorso de homem e pés de cabra, com face rosada, barba e chifres e coberto por uma pele de pantera. Em uma das mãos ele segura um bastão de pastor e na outra uma fístula, instrumento de sete canas, como mostram as figuras provenientes de duas edições do Iconologia:

31 "Come dipinto dal Bocaccio nel primo libro dela Genealogia delli dei." 


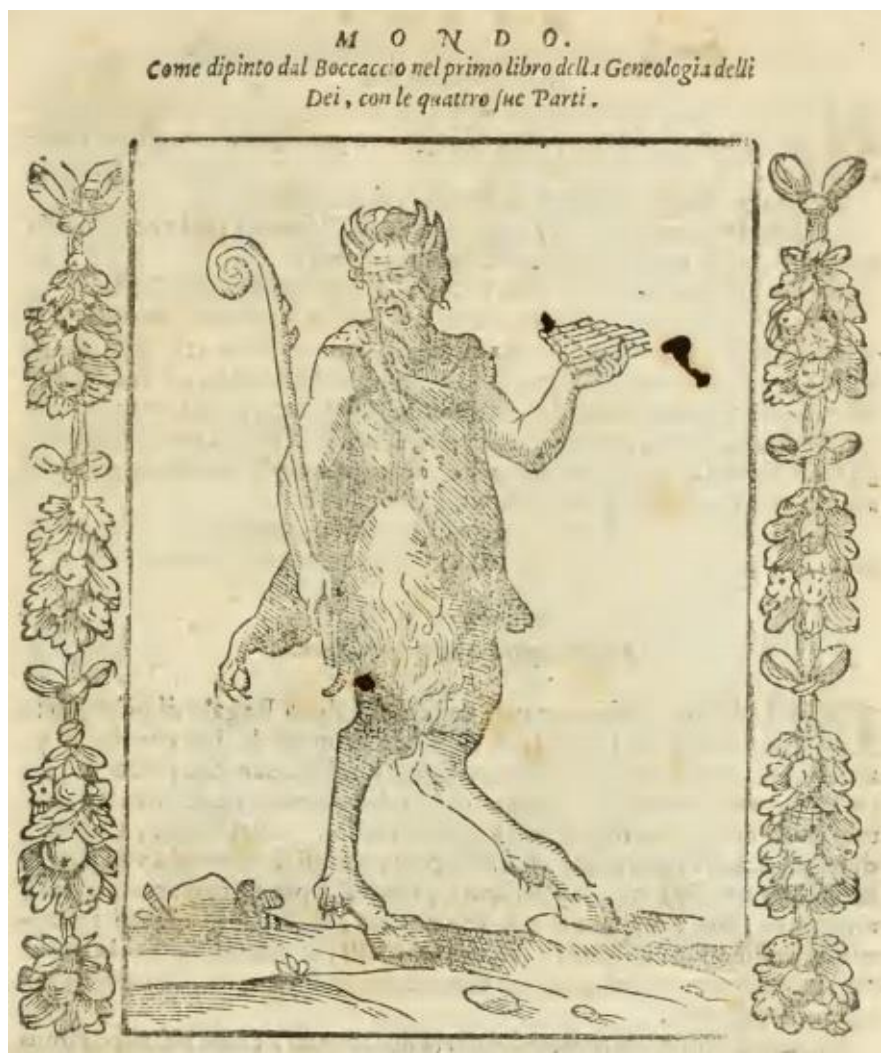

Fig. 9 - Alegoria do Mundo (RIPA, 1603)

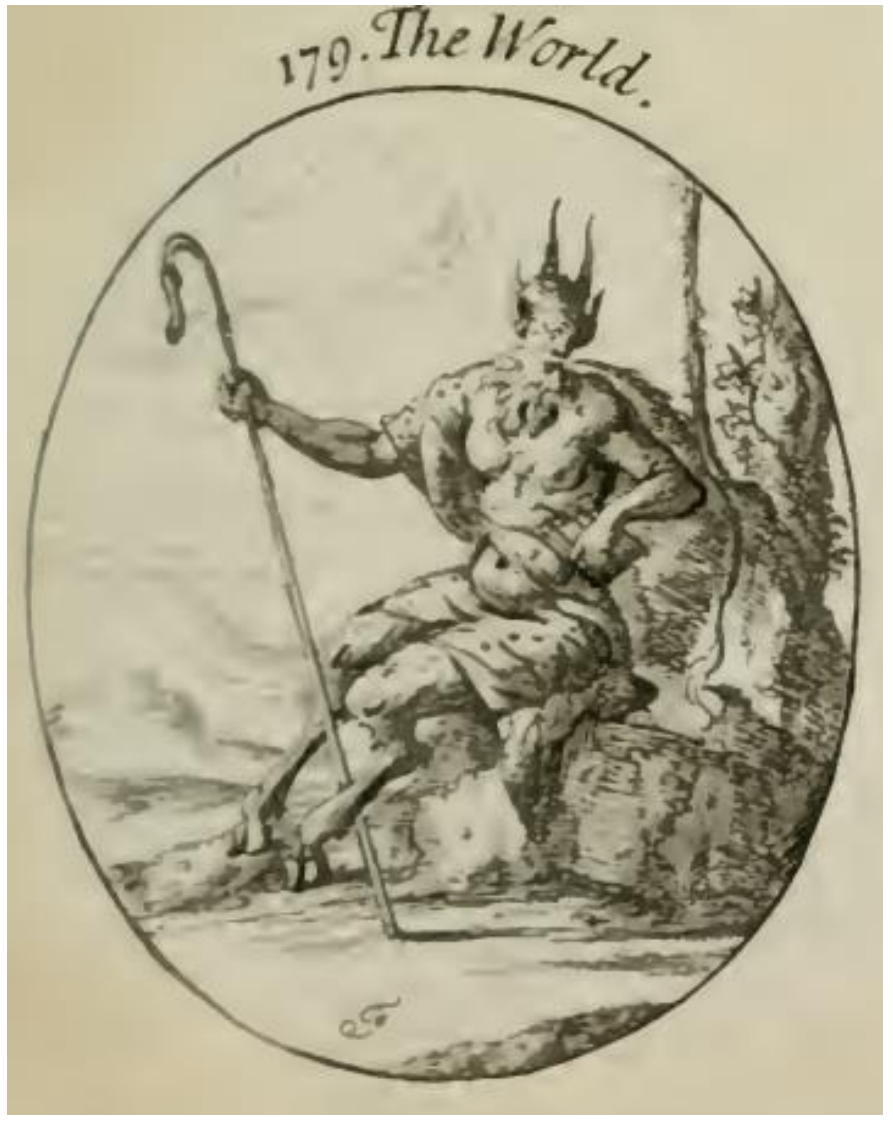

Fig. 10 - Alegoria do Mundo (RIPA, 1709) 
Ripa (1603, p.330-331) segue explicando que o termo "Pã" (ou Pan) significa "o universo", que os antigos quiseram representar por sua figura. Desse modo, cada parte de seu corpo corresponderia a um aspecto do planeta e do que o cerca: a metade cabra, peluda e hirsuta, a terra, "a qual é dura, áspera e toda desigual, coberta de árvores, muitas plantas e infinitas ervas" ${ }^{32}$; a face rosada e ardente, "o fogo puro que está sobre os outros Elementos, na fronteira da esfera celeste"33; a barba longa, "mostra que os dois Elementos superiores, o Ar e o Fogo, são de natureza e força masculina e que mandam impressões de natureza feminina" ${ }^{34}$; os chifres apontando para cima representariam o Sol e a Lua; a pele que o cobre, "a oitava esfera, toda pintada de claríssimas estrelas, que também cobre tudo aquilo que pertence à natureza das coisas" 35 ; o bastão, o governo da natureza. A fístula está presente por ter sido Pã "o primeiro que encontrou o modo de juntar várias canas com cera e o primeiro, ainda, a tocá-las, como diz Virgílio nas Éclogas" 36 .

As associações da fístula (a syrinx dos gregos) a Pã são antiquíssimas e, como se vê, ainda eram mantidas no século XVI. O famoso mito conta que Pã elaborara sua flauta juntando pedaços de diferentes tamanhos de um mesmo bambu (cana) no qual havia se transformado a ninfa Syrinx, que era perseguida por Pã e fora transformada na planta após ter pedido ajuda aos deuses para se livrar do homem-cabra. A popularidade do mito levou a flauta de Pã a ser associada às atividades pastoris e à forte ligação do semi-deus com a natureza. Essa questão foi até mesmo mencionada em importantes textos da Antiguidade, como na República de Platão, onde o pensador resolve banir a syrinx de sua cidade, permitindo, no entanto, que o instrumento fosse entregue aos pastores dos campos.

A fístula será também mencionada como parte de uma das alegorias representando a "Poesia":

\footnotetext{
32 "la qual'è dura, aspra, e tutta disuguale, coperta d'arbori d'infinite piante, \& di molt'herbe."

33 "foco puro, che sta sopra gli altri Elementi, in confine dele celesti sfere."

34 "mostra che i due Elementi superiori, cioè l'aria, e'l fuoco sono di natura, e forza maschile \& mandano le loro impressioni di natura feminile."

35 "l'ottava sfera, tutta dipinta di chiarissimi stelle, la quale parimente copre tutto quello che appartiene alla nature dele cose."

36 "il primo che trovasse il modo di comporre più canne insieme con cera, \& il primo che la sonasse ancora, come disse Virgilio nell'egloga."
} 
Jovem bela, vestida de azul-celeste, sobre qual vestimenta se farão muitas estrelas; será coroada de louros; mostra os seios nus plenos de leite, com a face inflamada e pensativa; com três meninos que giram ao seu redor; um porta a Lira e o Plectro, outro a Fístula e o terceiro, a Trombeta; e não se querendo representar os três [meninos] para não sobrecarregar o lugar, os ditos instrumentos serão colocados perto dela. (RIPA, 1603, p.406, tradução nossa) $)^{37}$

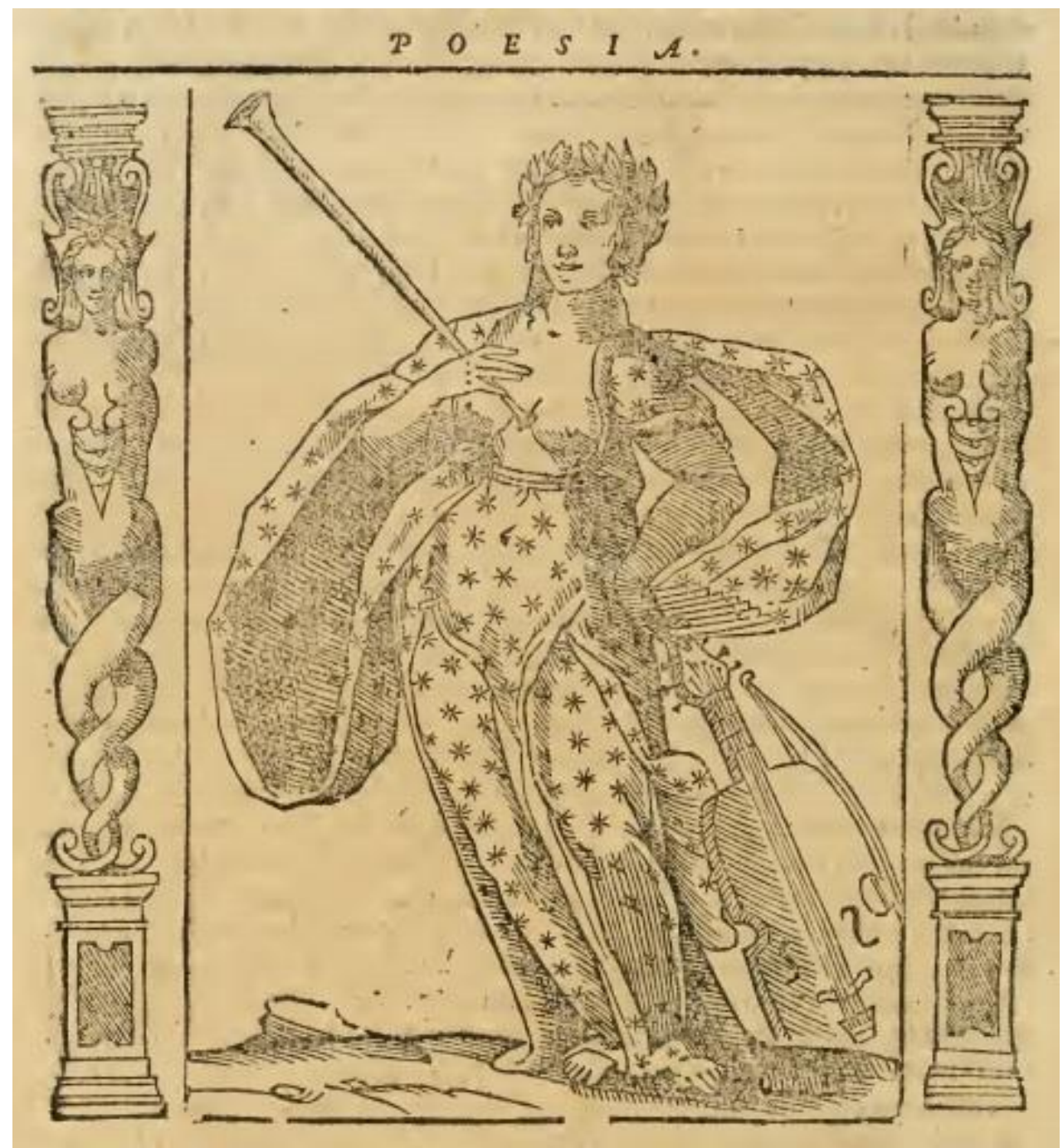

Fig. 11 - Alegoria da Poesia (RIPA, 1603)

37 "GIOVANE bela, vestita d'azurro celeste, sopra il qual vestimento vi saranno molte stelle, sarà coronata di alloro, mostri le mamelle ignude piene di lattem col viso infiammato, \& pensoso, con tre fanciulli à lati, che volandoli intorno, uno la porga la Lira, \& il Plettro, l'altro la Fistula, \& il terzo la Tromba; \& non volendo rappresentare i tre fanciulli per non ingombrare troppo il luogo, i detti istromenti si poranno appresso di essa." 
O texto segue dizendo que a Poesia, segundo Platão, "não é outra coisa senão a expressão das coisas divinas avivadas na mente pelo furor e graça celestiais" ${ }^{38}$. Descrevendo os elementos da alegoria, Ripa continua:

\begin{abstract}
Pinta-se jovem e bela porque todo homem, ainda que áspero, é seduzido por sua doçura e tira dela sua força. Coroa-se de louro, que está sempre verde, e não teme a força do relâmpago celeste, porque a Poesia faz os homens imortais e os protege dos golpes do tempo, que reduz todas as coisas ao esquecimento. A veste com as estrelas significa a divindade, em conformidade àquilo que, como disseram os Poetas, tem origem no céu. Os seios plenos de leite mostram a fecundidade dos conceitos e das invenções que são a alma da Poesia. E pensativa e inflamada no aspecto porque a Poesia tem sempre a alma plena de movimentos velocíssimos semelhantes ao furor. As três crianças são as três maneiras principais de se fazer poesia, que são a Pastoral, a Lírica e a Heroica. (RIPA, 1603, p.406-7, tradução nossa) $)^{39}$
\end{abstract}

Após a leitura dessa descrição, ficam claras as funções dos instrumentos musicais nessa alegoria: cada um representa um dos gêneros da poesia clássica. A Trombeta, o gênero Heroico, enquanto a Lira representa o Lírico (falar-se-á sobre esses instrumentos a seguir). Logicamente, a flauta de Pã fica aqui encarregada da representação da poesia Pastoral. É possível ver na ilustração anterior (mesmo que um tanto quanto escondida) a flauta de Pã na mão esquerda da figura (logo acima do braço da lira de arco apoiada no chão), com seus mencinados sete tudos de cana colados lado a lado.

A edição de 1625 apresenta uma gravura muito parecida com a anterior, seguindo também o mesmo texto da edição de 1603. No entanto, parece haver uma certa confusão na representação dos instrumentos, já que na gravura constam apenas dois dos três mencionados. A flauta de Pã está ausente, e o instrumento na mão direita da figura, que na gravura anterior representava uma Trombeta, tem agora um aspecto de instrumento de sopro de madeira, apresentando furos ao longo do tubo:

\footnotetext{
38 "no è altro, ch'espressione di cose divine eccitate nella mente da furore, \& gratia celeste."

39 "Si dipinge giovane, \& bella, perche ogni huomo, ancorche rozzo, è allettato dalla sua dolcezza, \& tirato dalla sua forza. Si corona di lauro, il quale stà sempre verde, \& non teme forza di fulmine celeste, perche la Poesia fà gl'huomini immortali, \& gli asicura da colpi del tempo, il quale suol tutte le cose ridurre all'oblivione. La veste con le stelle, significa la divinità, per conformità di quello, che differo $\mathrm{i}$ Poeti haver origine dal cielo. Le mammelle piene di latte, mostrano la secondità de concetti, e dell'inventioni, che sono l'anima della Poesia. E pensosa, \& infiammata nell'aspetto, perche il Poeta hà sempre l'anima piena di velocissimi motti somiglianti al furore. I tre fanciulli, sono le tre maniere principal di poetare, cioè Pastorale, Lirico \& Heroico."
} 


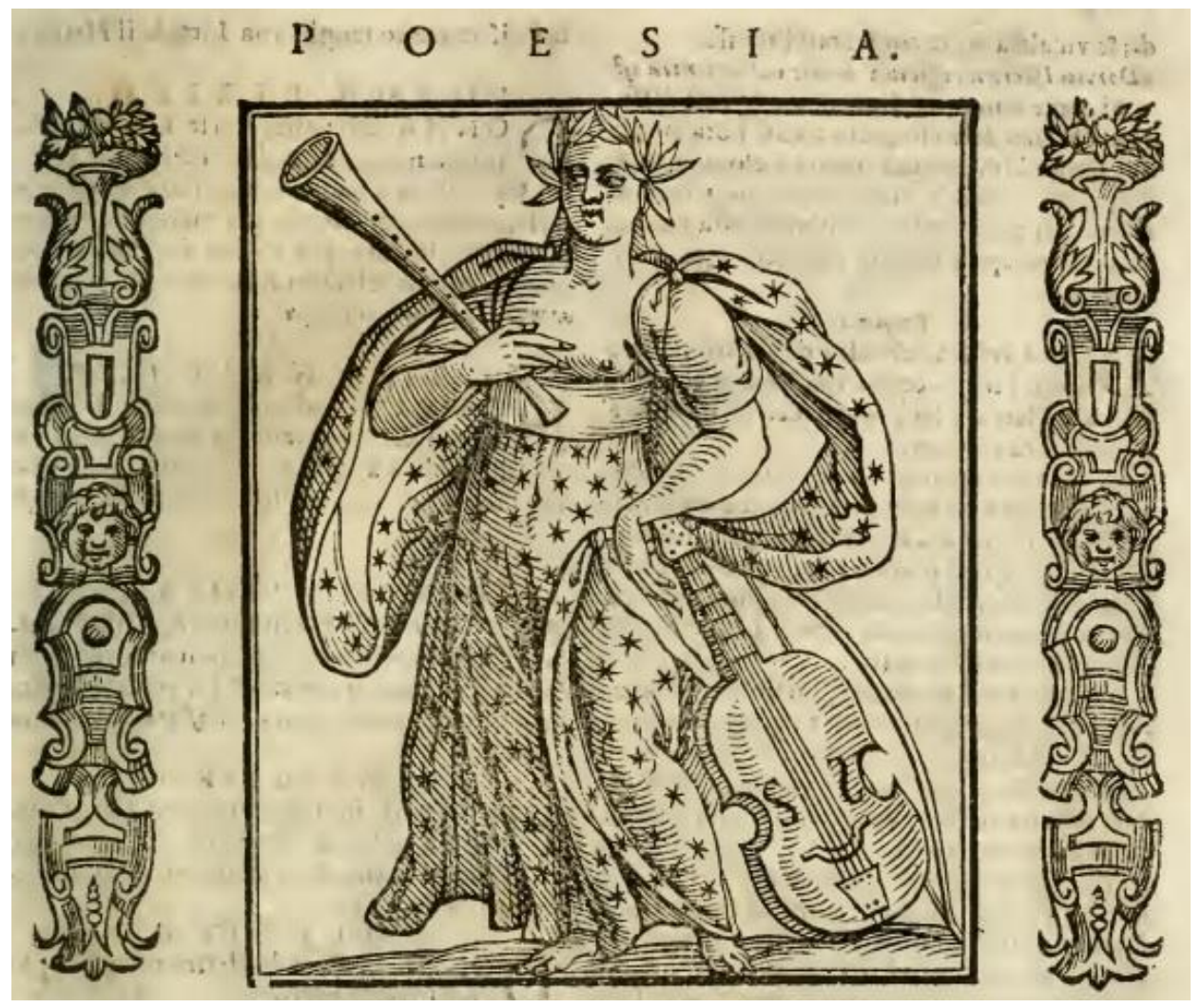

Fig. 12 - Alegoria da Poesia (RIPA, 1625)

Sendo essa gravura claramente baseada na anterior, supõe-se que o artista tenha cometido um erro em sua execução.

A ilustração da alegoria da Poesia presente na edição francesa de 1637 também não dá espaço à flauta de Pã. São mostrados apenas a lira de arco e um instrumento que assemelha-se à trombeta, mas que provavelmente representa um sopro de madeira, já que o texto dessa publicação descreve a Poesia devendo ter à mão esquerda uma lira e à mão direita "um tipo de oboé [haut-Bois] ou de flauta"40 (1637, p.198, tradução nossa). A presença do termo Haut-bois mostra a substituição por parte do editor de um instrumento por outro provavelmente mais conhecido na época e no local dessa publicação. A trombeta é citada como denotação da Poesia Heroica, mas não é descrita como parte da representação da alegoria.

40 "une maniere de haut-Bois, ou de Fluste." 


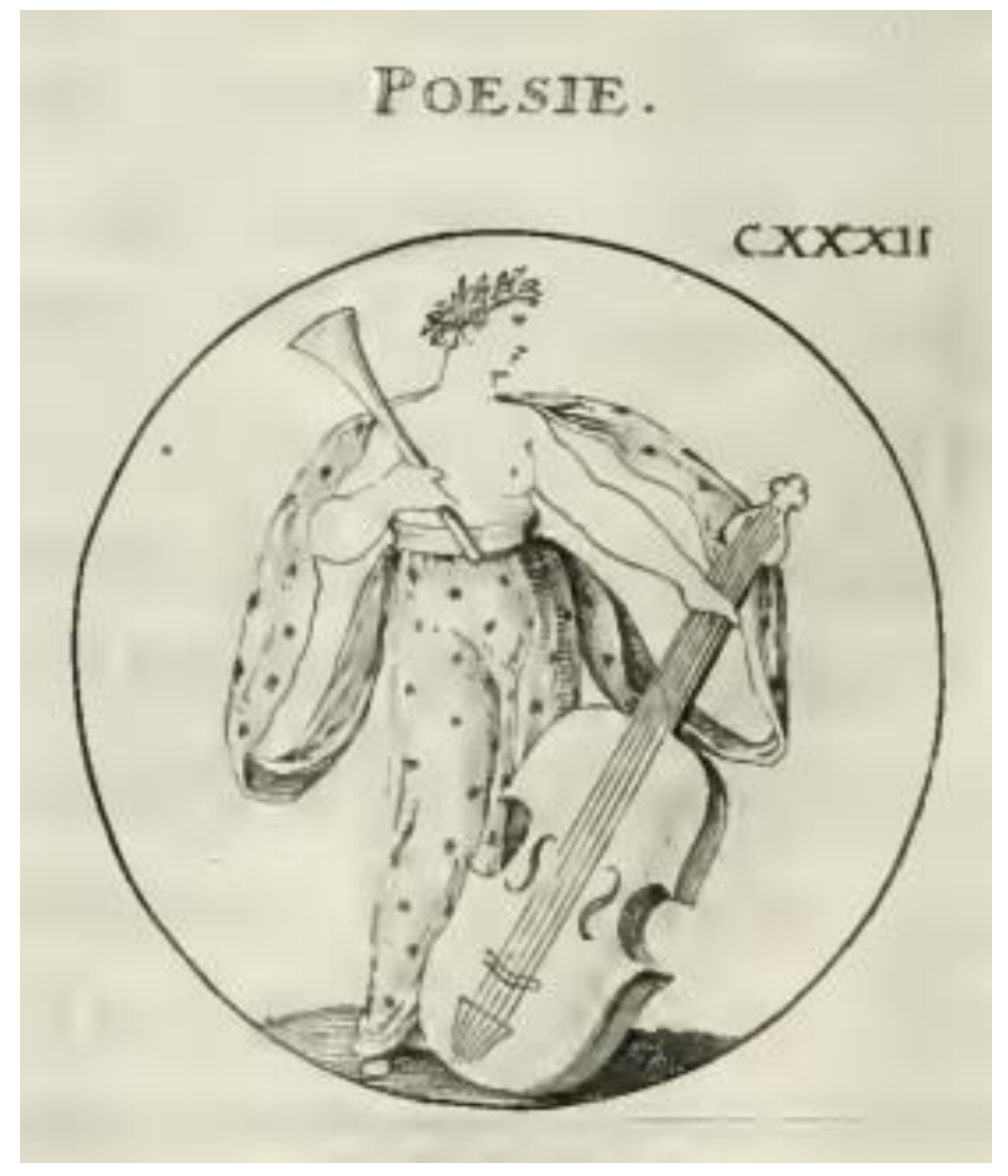

Fig. 13 - Alegoria da Poesia (RIPA, 1637)

Tromba:

Em Ripa, o termo tromba parece designar, genericamente, um instrumento de sopro de metal, referindo-se a algum tipo de trombeta. Seu uso nas alegorias ressalta sempre suas características de um instrumento de forte e robusta sonoridade, capaz de ser ouvido a longas distâncias e que por isso tem a função constante de mensageiro, como sendo um poderoso propagador de ideias ou notícias.

Por suas características, os instrumentos de metal, em especial as trombetas, foram também tradicionalmente associados ao poder, seja ele divido ou humano. São, portanto, os instrumentos dos deuses e dos reis, dotados da pompa e da força sonora necessárias para representá-los. Por exemplo, anjos arautos e soldados das guardas reais são com frequência representados portando instrumentos de metal. 
Nesse contexto, a trombeta faz parte da figura alegórica da Poesia, representando ali o Poema Heroico, por razões óbvias.

O uso da trombeta em alegorias de "coisas boas" aparece também na descrição da "Boa Fama", onde Ripa escreve (1593, p.74, tradução nossa): "Mulher, com uma trombeta na mão direita e na esquerda um ramo de oliveira; terá assas brancas." ${ }^{41} \mathrm{~A}$ função do instrumento de metal fica clara a seguir: "A trombeta significa o grito universal propagado nas orelhas dos homens." ${ }^{42} \mathrm{O}$ autor continua a descrição mostrando o ramo de oliveira como representante da "bondade da fama e a sinceridade do homem famoso por obras ilustres" e diz que as asas brancas "indicam a candura e velocidade da fama". ${ }^{43}$

Já em uma de suas representações, a "Glória" é descrita como "uma mulher com uma coroa de ouro na cabeça e na mão direita uma trombeta" (RIPA, 1593, p.110, tradução nossa $)^{44}$. Na explanação da alegoria, o autor mostra que a coroa é indício do prêmio que merece cada homem famoso e que "pinta-se [a figura] com a trombeta em mãos porque com ela se publica ao povo o desejo dos Príncipes" ${ }^{45}$.

Porém, fora do contexto das "coisas boas", fazendo parte da "Jactância", a trombeta na mão esquerda da figura representa o louvor a si mesmo, já que no instrumento tanto o ar do sopro como o som são obtidos da mesma boca.

\footnotetext{
41 "DONNA, con una Tromba nella mano dritta, \& nella sinistra con un ramo d'Uliva, haverà l'ali bianche."

42 "La Tromba significa il grido universale sparso per gli orecchi de gli huomini."

43 "la bontà della fama, \& la sincerità dell'huomo famoso per opere illustri"; "L'ali di color bianco notano la candidezza, \& la velocità della fama."

44 "DONNA, con una Corona d'oro in capo, \& nella destra mano con una Tromba."

45 "si dipinge con la Tromba in mano perche con essa si publicano à popoli i desiderij de' Prencipi."
} 


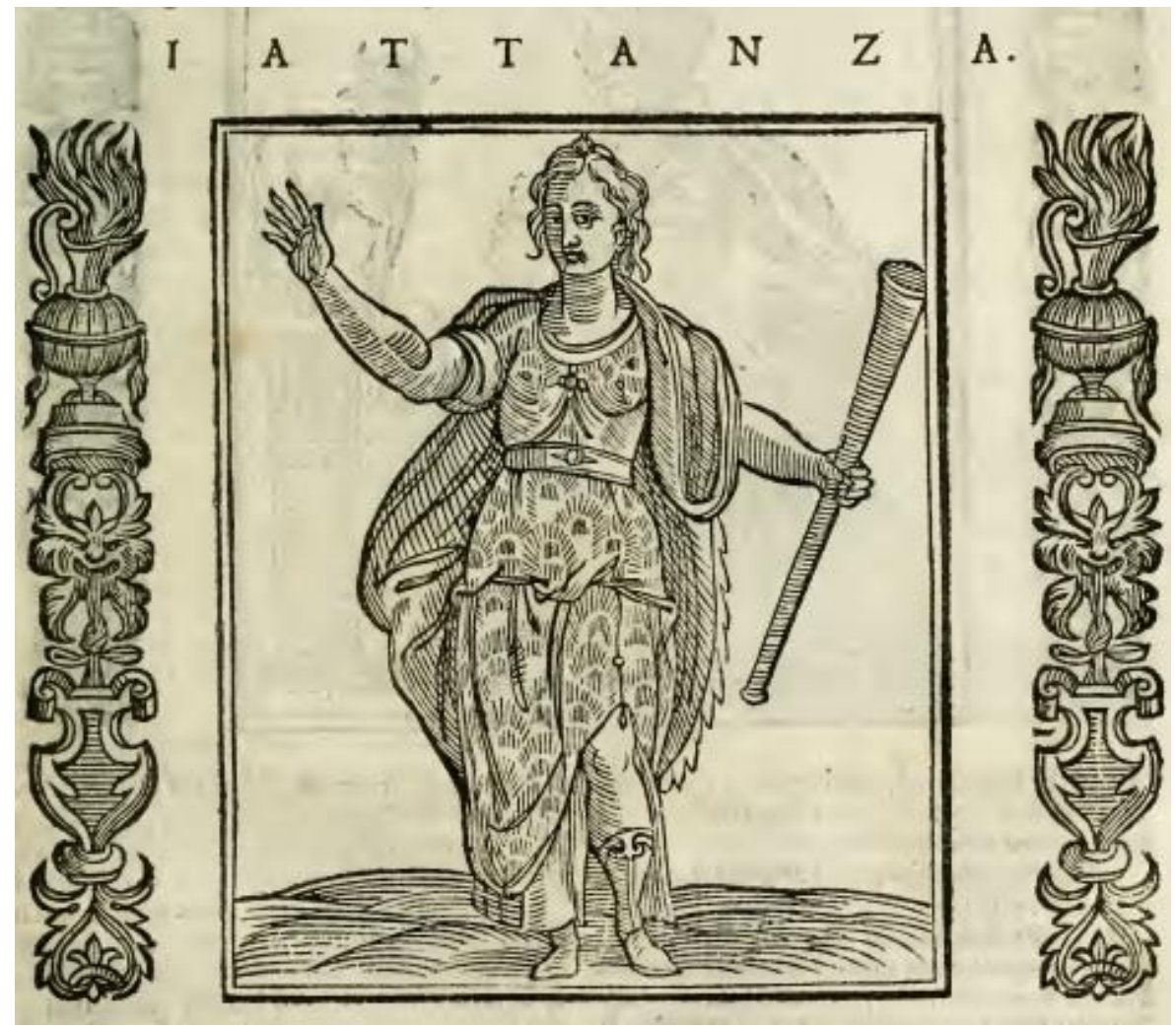

Fig. 14 - Alegoria da Jactância (RIPA, 1625)

Harpa:

A harpa é citada algumas vezes no Iconologia, tendo destaque na figura que representa o "Prazer": 


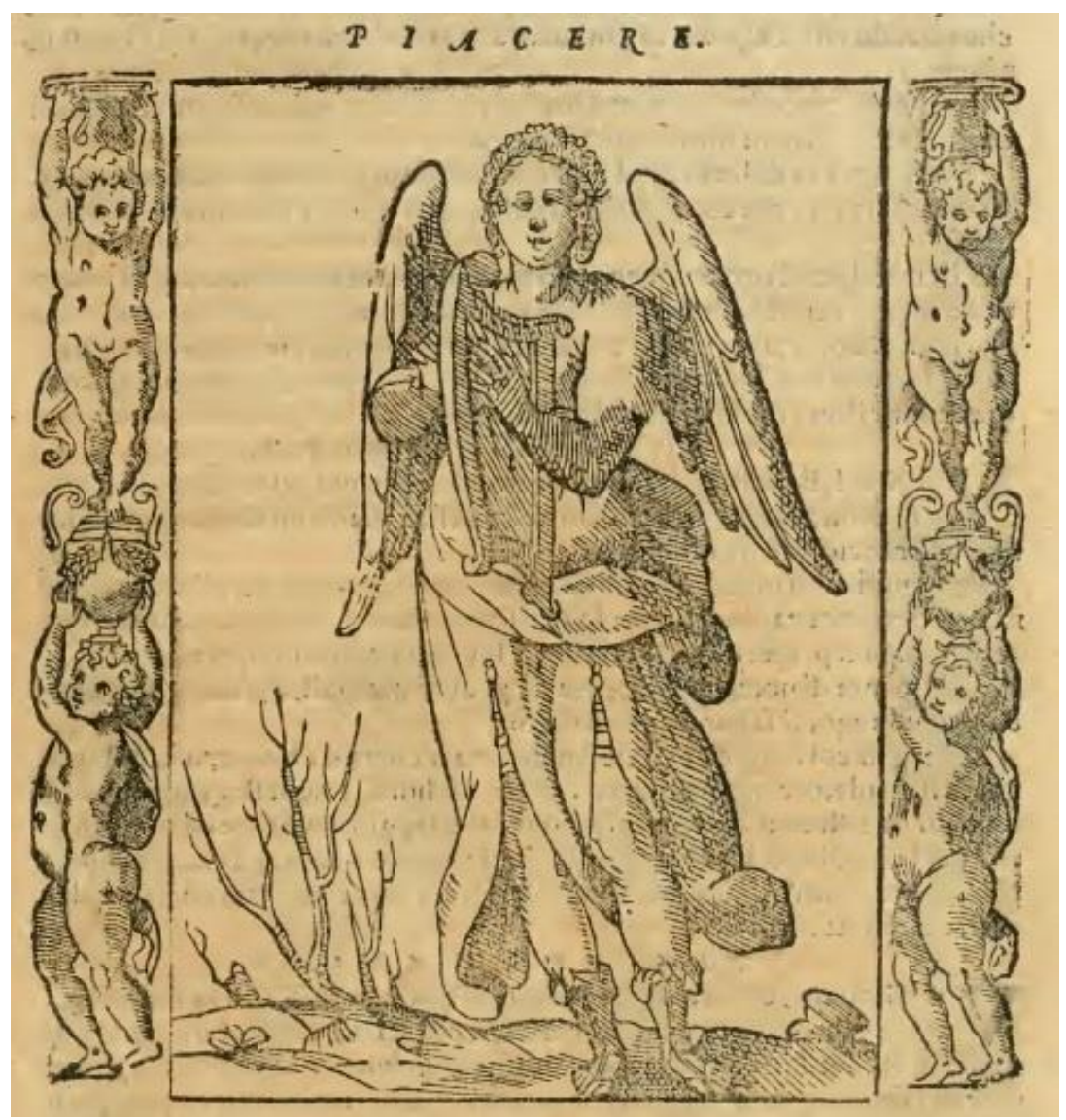

Fig. 15 - Alegoria do Prazer (RIPA, 1603)

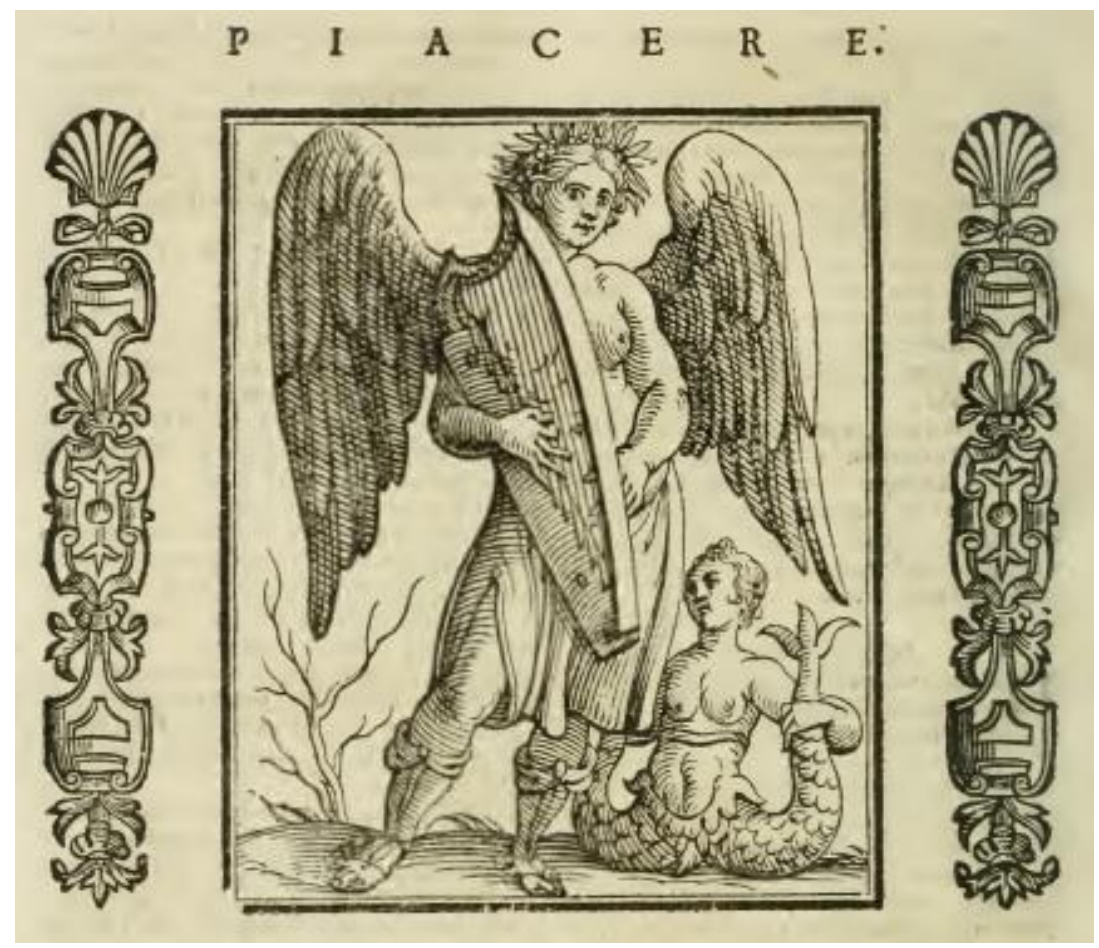

Fig. 16 - Alegoria do Prazer (RIPA, 1625) 


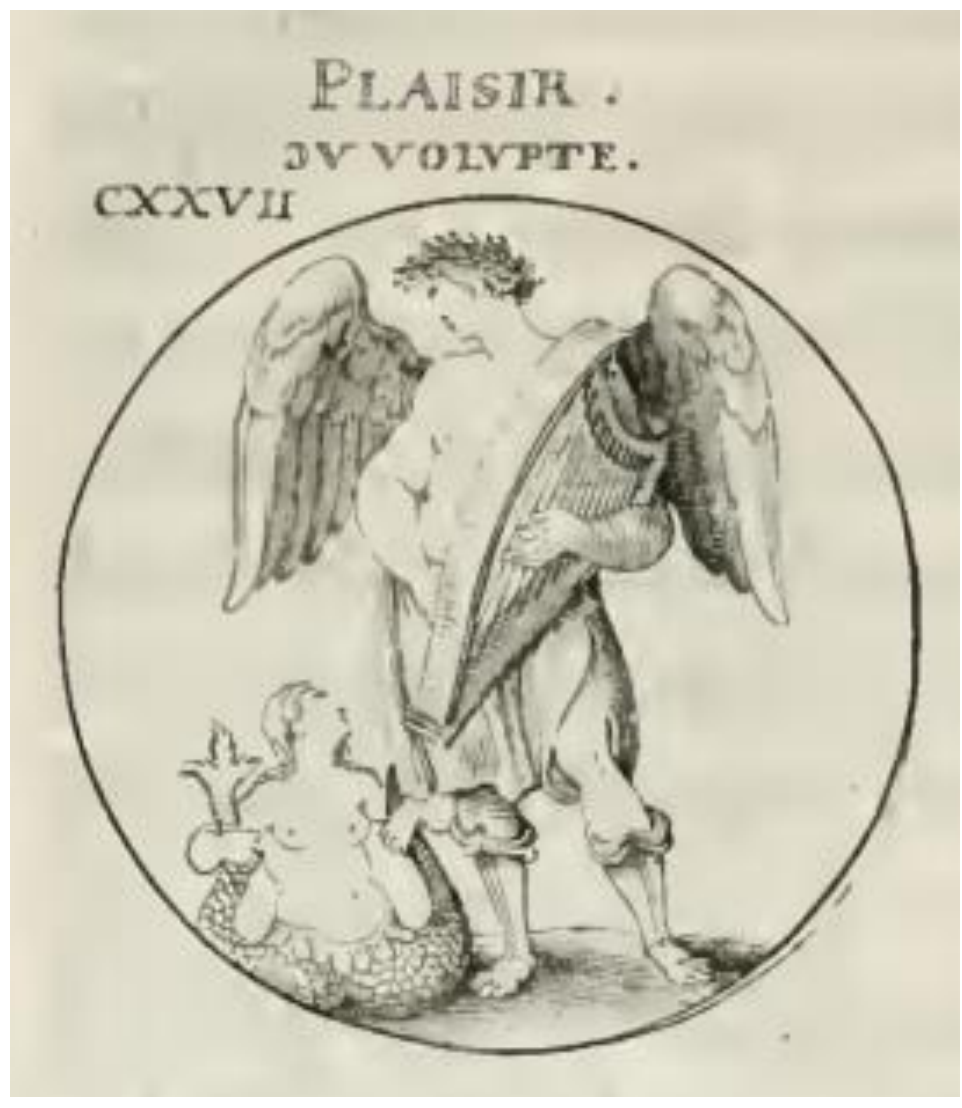

Fig. 17 - Alegoria do Prazer (RIPA, 1637)

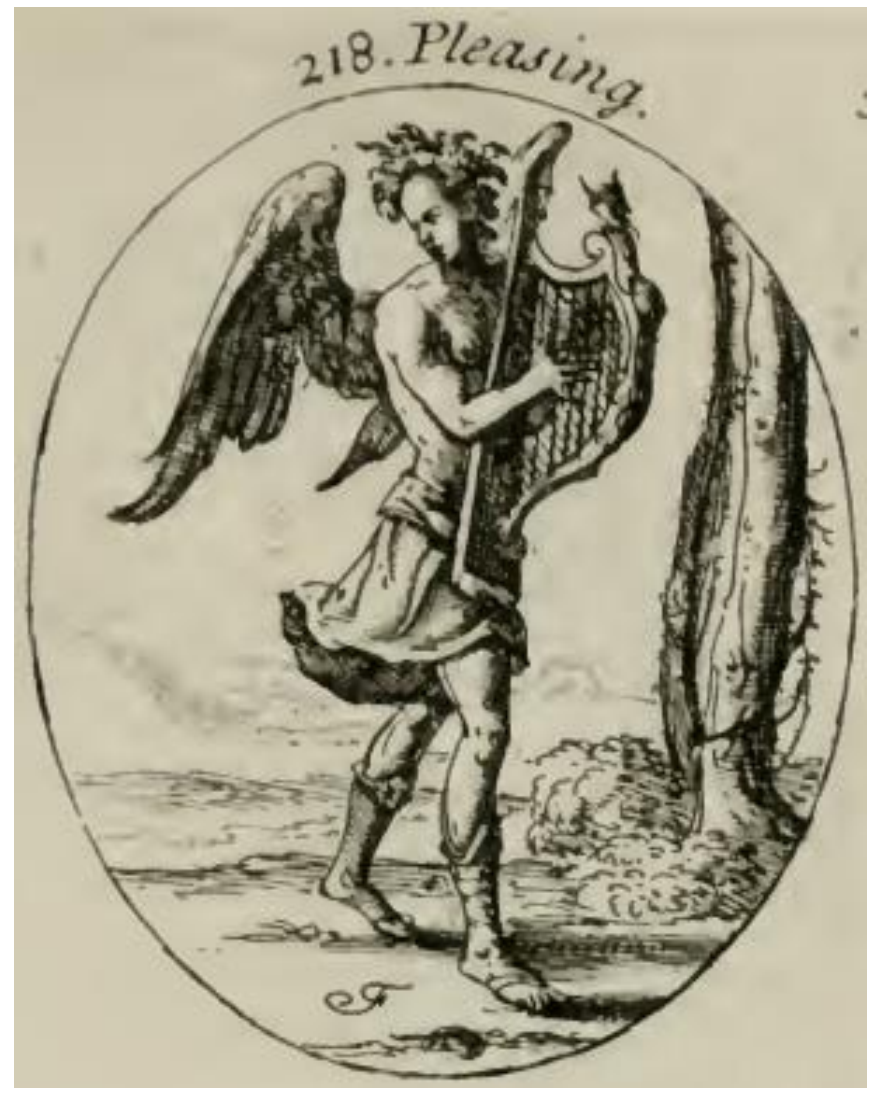

Fig. 18 - Alegoria do Prazer (RIPA, 1709) 
Em uma de suas formas, a alegoria é descrita como um jovem de cabelos louros encaracolados, decorados com flores e uma guirlanda circundada de pérolas. Está nu e tem asas coloridas. Usa calçados dourados e nas mãos tem uma harpa. Em algumas descrições, como se vê nas figuras 16 e 17, tem a seu lado uma sereia.

Sua bela cabeleira representa a delicadeza, a lascívia e os hábitos femininos. As flores e pedras preciosas ali encontram-se por serem incitamentos ao prazer. As asas indicam sua efemeridade, já que o prazer logo voa para longe. Os calçados dourados mostram que o ouro conta pouco ao prazer, já que não satisfaz seus apetites, e também representa a inconstância.

A presença da harpa é bem explicada por Ripa que diz que ela associa-se a Vênus e às Graças, pela doçura de seu som que "deleita a alma e renova o espírito" (1603, p.400, tradução nossa). ${ }^{46}$

A presença da sereia nas ilustrações também é fruto de uma junção numa mesma figura de características de diferentes descrições do Prazer. Nesse caso, a criatura mitológica que seduz os marinheiros com seu canto e os assassina nas águas mostra que o prazer também seduz e leva à ruína os seus seguidores.

A harpa também faz parte de alegorias para a "Adolescência" e para a "Alegria do amor", provavelmente pelo mesmo motivo relacionado ao "Prazer".

Nas figuras, vê-se claramente a representação de harpas diatônicas (com apenas um conjunto de cordas), em formatos comuns durante o Renascimento. Nelas, o instrumento oriundo do antigo saltério não parece ser confundido com a antiga lira grega em sua aparência característica.

Alaúde:

Em Ripa, o alaúde aparece em meio à descrição da alegoria para o Escândalo, tendo ali, assim como a tíbia (que também faz parte dessa imagem), a função de representar atividades de lazer e distração nas quais a música estava presente. No entanto, ele figura de forma mais relevante na representação do temperamento sanguíneo, dito "Sanguíneo pelo Ar". Ali, o instrumento não divide espaço com outros

\footnotetext{
46 "diletta gl'animi, e ricrea li spiriti."
} 
e é posto nos braços da figura que o toca. Ripa indica que ela se mostra encantada com os sons e com o canto, característica da pessoa de temperamento sanguíneo.

Apesar de sua ligação com os instrumentos de cordas dedilhadas antigos e suas conotações simbólicas, o alaúde parece ser empregado nessa alegoria por questões mais próximas aos tempos do autor. Muito popular na época de Ripa como um instrumento da corte, o alaúde era bem-visto e bem-quisto entre os homens considerados de boa educação, como fica claro em trechos de /l Cortegiano, de Baltassare Castiglione, publicado em 1528 e muito provavelmente conhecido por Cesare Ripa. No livro, que descreve com detalhes a vida e os costumes da corte europeia do século $\mathrm{XVI}$, o alaúde é visto como um instrumento perfeito para o cortesão educado, que poderia tocá-lo e cantar ao mesmo tempo, embelezando sua música:

\footnotetext{
- Em minha opinião a música escrita é encantadora - respondeu o Senhor Federico - assim sendo, deverá ser executada em bom estilo e com precisão. Mas cantar com acompanhamento de alaúde é ainda melhor, pois toda doçura harmoniza-se num todo... Todavia, cantar um poema acompanhado por alaúde parece-me especialmente aprazível, pois este instrumento acrescenta às palavras tal encanto e efetividade que é realmente maravilhoso. (ZWILLING, 2016, p.6)
}

Por essa razão, Ripa pode ter utilizado o alaúde junto à figura do temperamento humano que é conectado ao ar, à juventude, à vivacidade e à alegria. 


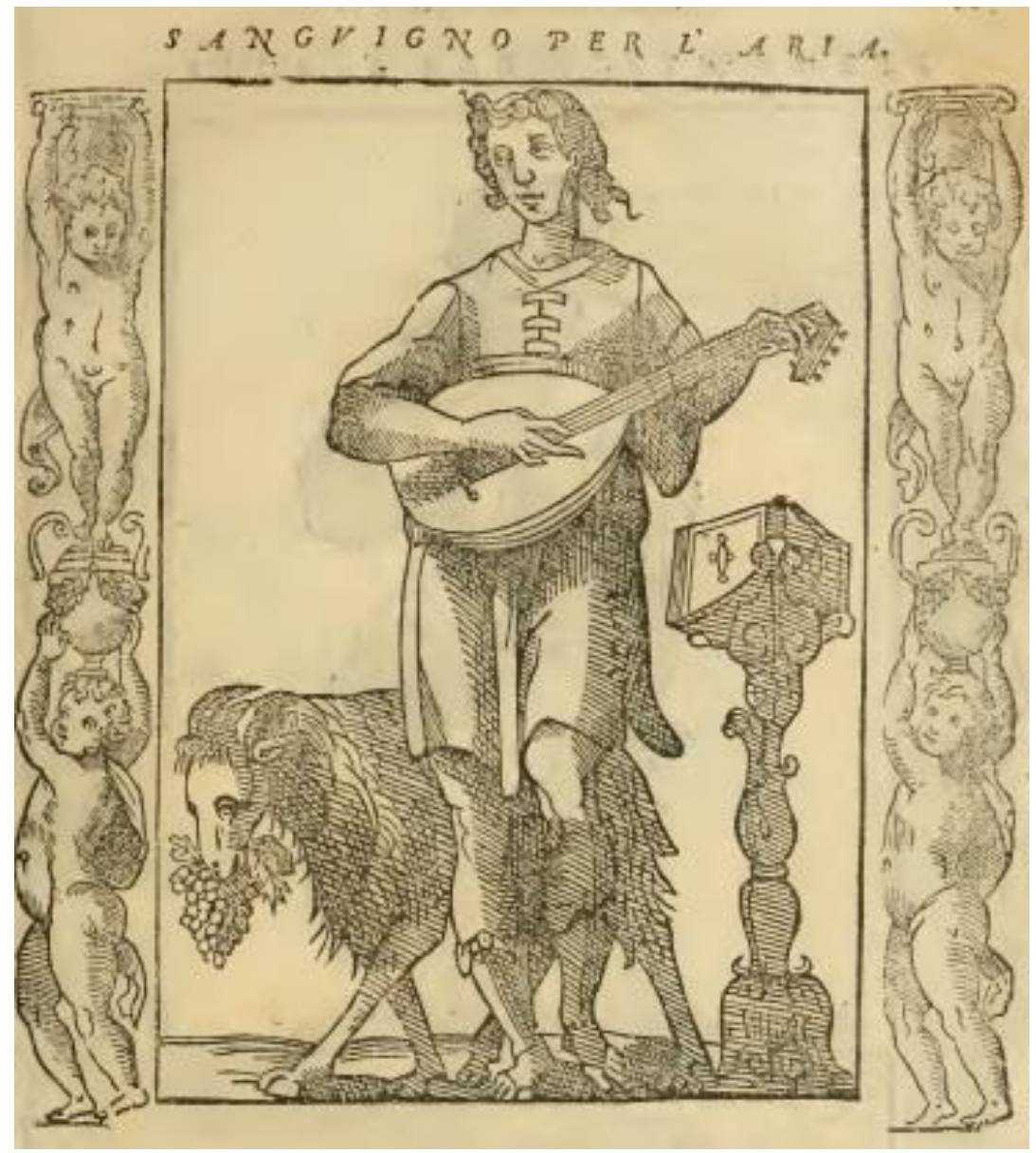

Fig. 19 - Alegoria do temperamento Sanguíneo (RIPA, 1603)

Lira:

Quando figura entre as alegorias do Iconologia, o termo lira parece sempre designar o instrumento de cordas friccionadas por arco conhecido como Lira da Braccio ou ainda sua versão mais grave, o Lirone.

Vê-se que na Renascença a substituição de instrumentos antigos por outros modernos nas artes visuais era constante e a lira da braccio toma o lugar da antiga lira grega por diversas vezes: em obras renascentistas, as figuras mitológicas de Apolo e Orfeu, famosos por suas habilidades à lira, surgem tocando instrumentos de arco, ao invés dos de cordas dedilhadas.

Winternitz (1979, p.86, tradução nossa) afirma que 
a lira da braccio foi um dos mais importantes instrumentos de cordas do Alto Renascimento, o instrumento dos recitalistas que improvisavam acompanhamentos polifônicos para seu canto, e portanto um dos mais característicos implementos do desejado reestabelecimento da arte rapsódica dos antigos. ${ }^{47}$

A lira da braccio, mais do que qualquer outro instrumento do renascimento italiano, esteve associado à tentativa da recriação da prática musical da antiguidade. Seu uso ficou praticamente restrito à Itália. No entanto, ali gozou de grande popularidade e respeito, não à toa figurando relevantemente em meio às artes e à literatura daquele país durantes os séculos XV e XVI. A lira era vista como instrumento de alta estirpe por parte dos estudiosos e artistas do perído, como afirma Winternitz: “(...) nas últimas décadas do quattrocento (...) humanistas e poetas teriam desdenhado qualquer coisa que não fosse a nobre lira da braccio polifônica." (p.44, tradução nossa) $)^{48}$

O alto conceito de que o instrumento gozava devia-se justamente à sua aparente relação com a lira da antiguidade, relação essa que a fazia merecedora de representar o instrumento de Apolo e todas as suas conotações simbólicas. Winternitz (1979, p.96, tradução nossa) explica que

seu nome, sua suposta origem clássica, e suas específicas ou imaginadas similaridades com a lira antiga (...), contribuíram para dar a ela uma significância alegórica que é claramente espelhada nas artes visuais e no tipo de literatura alegemblemática do período. ${ }^{49}$

No Renascimento, o instrumento figurará "como o atributo simbólico dos grandes poetas e músicos do Velho Testamento: Apolo, Orfeu, Homero, e do Rei Davi (...)", bem como entre algumas figuras alegóricas, como a da Música entre as artes liberais.

\footnotetext{
47 "The lira da braccio was one of the most important string instruments of the High Renaissance, the instrument of the recitalists who improvised polyphonic accompaniments for their singing, and therefore one of the most characteristic implements of the intended revival of the rhapsodic art of the ancients."

48 "(...) the last decades of the quattrocento (...) humanists and reciting poets, would have disdained anything other than the noble polyphonic lira da braccio."

49 "its name, its supposed antique origin, and its specific or imagined similarities to the ancient lyre, (...), all contributed to endow it with a kind of allegorical significance that is clearly mirrored in the visual arts and in the allegorical and emblematic literature of the period."
} 
O autor explica também as associações entre os dois instrumentos:

A hipótese de que a lira da braccio era um instrumento antigo era aparentemente baseada em diversos fatos. O número de cordas - sete lembrava aquele da clássica lira antiga. Além disso, a lira da braccio tinha, além das cordas para serem pressionadas pelos dedos do intérprete, cordas livres que sempre soavam em toda sua extensão, assim como as cordas das antigas kithara e lira. Finalmente, acreditava-se amplamente que o antigo plectro da kithara e da lira era na verdade alguma coisa como um arco de rabeca (violino), e foi apenas em 1581 que essa hipótese foi energicamente refutada por Vincenzo Galilei.

No Iconologia, quando ilustrada, a lira citada no texto aparece como um instrumento de arco. Na edição de 1625 vê-se a alegoria do "Deleite" da seguinte forma:

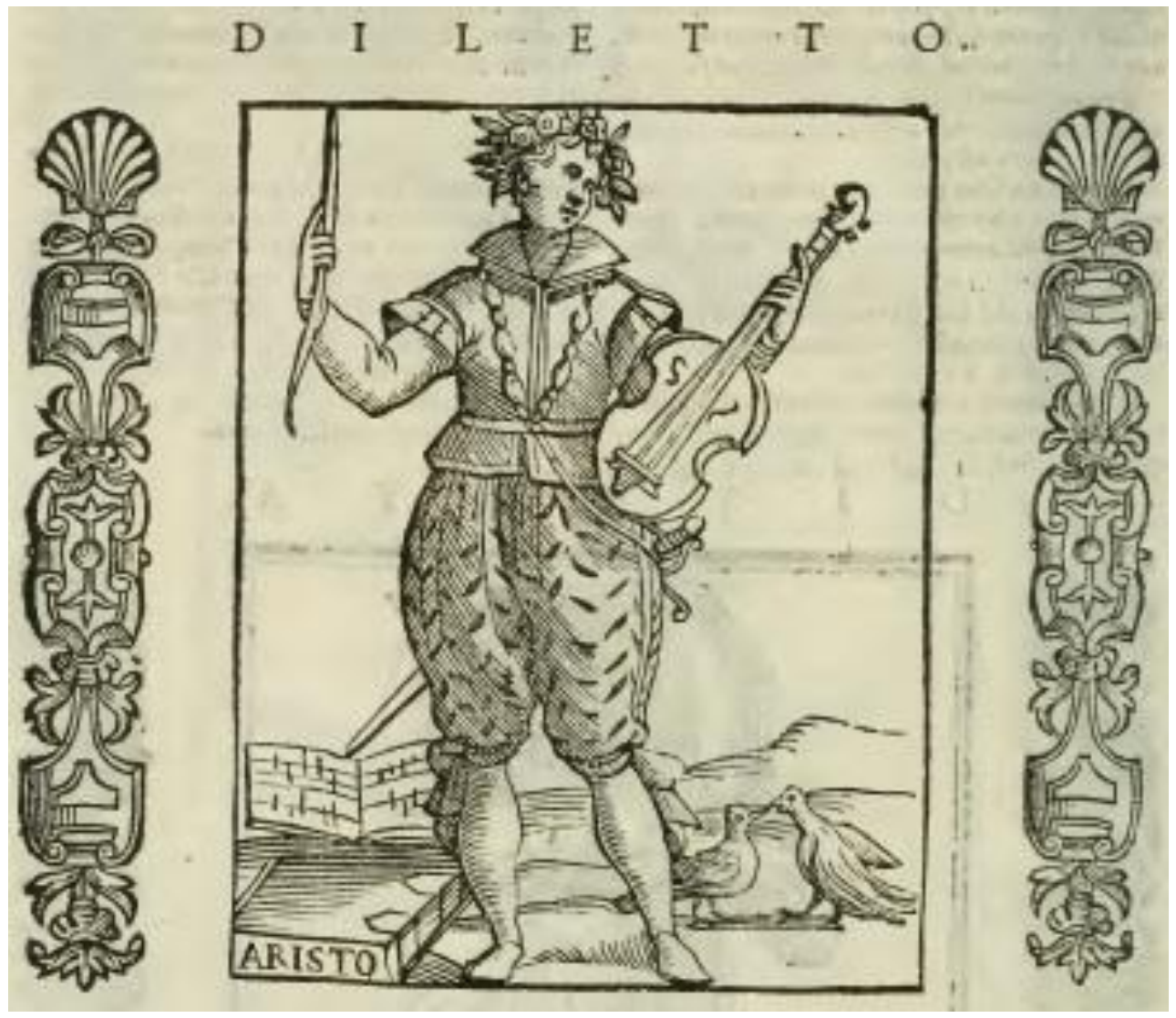

Fig. 20 - Alegoria do Deleite (RIPA, 1625) 
O texto a descreve como um jovem de belíssimo e alegre aspecto, que "terá à mão esquerda uma lira apoiada ao lado esquerdo e a outra [mão] levantada com o plectro" (RIPA, 1626, p.172, tradução nossa) $)^{50}$. Com estabelece a descrição, na alegoria, o instrumento levado pela figura representa a audição, sendo essa "um sentido nobilíssimo". Por sua importância para o aprendizado e o saber, diz-se que os antigos criam que as orelhas eram consagradas à Sabedoria e à Prudência. Mais uma vez, direciona-se a figura da lira à sua antiga simbologia.

Curiosamente, o texto aponta a presença de um plectro. Porém, na ilustração vemos um arco. Como mencionado por Winternitz, havia uma forte crença no fato de que o plectro das liras antigas teria sido uma espécie de arco e, mesmo tendo sido a ideoa combatida por Galilei no fim do século XVI, essa crença parece ter persistido durante um período depois disso. No Iconologia, a Lira é frequentemente citada juntamente com um plectro, que é, por sua vez, ilustrado como um arco nas gravuras.

A figura retratando a Poesia, vista anteriormente, tem ao seu lado uma lira com um arco, e o texto que a descreve também faz menção ao plectro. Portanto, a transposição de plectro para arco poderia ser deveras direta e óbvia para os ilustradores da época e também, provavelmente para os escritores e leitores do período. Afinal,

o fato do ato de se tocar com um arco ser desconhecido na antiguidade grega e romana não incomodava pintores, cenógrafos ou historiadores renascentistas da música, porque naquela época a invenção do arco era atribuída a Sappho; e as estátuas e relevos de Apolo e das Musas não os mostravam usando plectros - algo, poderia-se pensar, parecido com um arco? (WINTERNITZ, 1979, p. 44, tradução nossa) $)^{51}$

A alegoria da "Harmonia" é descrita tocando uma lira dupla de quinze cordas (lira doppia a quindici corde). Winternitz (p.87, tradução nossa) explica que "os nomes para as formas maiores [da lira da braccio], com mais de sete cordas, eram lirone,

\footnotetext{
50 "Terrà con la sinistra mano uma lira appogiata al fianco sinistro, \& la destra alzata con il pletro."

51 "The fact that bowing was unknown in Greek and Roman antiquity did not disturb Renaissance painters, stage designers, or musical historians because at that time the invention of the bow was attributed to Sappho; and did not statues and reliefs of Apollo and the Muses show them using large plectra - something, one might think, like bows?"
} 
lirone perfetto, lira da gamba, e arciviolatalira (provavelmente uma corruptela de arciviola da lira)" ${ }^{\prime 2}$. As edições italianas dão a essa alegoria uma descrição curta e nenhuma explanação. Tudo o que se lê é "Uma vaga e bela mulher, com uma lira dupla de quinze cordas nas mãos, na cabeça abrigará uma coroa com sete joias todas iguais, a vestimenta é de sete cores, guarnecida com ouro e diversas joias" (RIPA, 1603, p.26, tradução nossa) $)^{53}$.

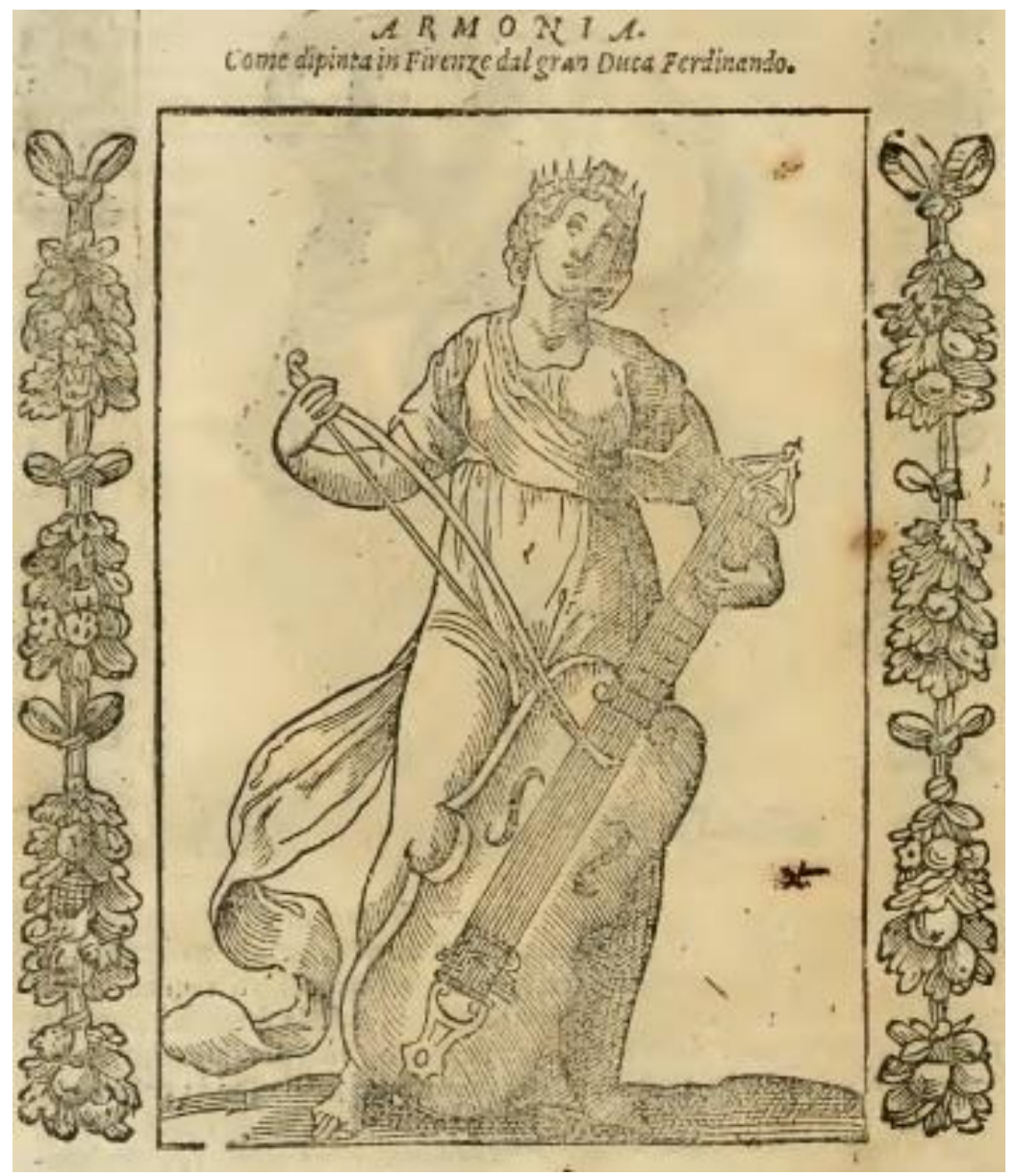

Fig. 21 - Alegoria da Harmonia (RIPA, 1603)

O instrumento mostrado na ilustração, apesar de sua descrição, claramente não possui quinze cordas. Nesse contexto a gravura da "Poesia" mostrada anteriormente também representaria um lirone, devido às dimensões do instrumento desenhado, mesmo sendo retratado com apenas cinco cordas. Apesar de estranhas,

\footnotetext{
52 "The names for the larger forms, with more than seven strings, were lirone, lirone perfetto, lira da gamba, and arciviolatalira (probably a corruption of arciviola da lira)."

53 "UNA vaga, \& bella donna, con una lira doppia di quindici corde in mano, in capo haverá uma corona con sette gioie tutte iguali, il vestimento è di sette colori, guarnito d'oro, \& di diverse gioie."
} 
essas incongruências e simplificações dos instrumentos poderiam ocorrer devido à dificuldade de ater-se a detalhes em alguns meios artísticos.

Winternitz fala também da simbologia envolvendo a quantidade de cordas da lira: "Frequentemente, ao número de cordas é dada significância simbólica - o número sete, por exemplo, referindo-se aos sete planetas conhecidos". A partir disso, pode-se imaginar que as sete joias e sete cores das roupas da alegoria da Harmonia teriam relação com essa questão, podendo significar aqui, entre outras coisas, o famoso conceito da "harmonia das esferas" de Pitágoras.

De qualquer forma, o Iconologia reitera a tendência do renascimento italiano à visão da lira como um instrumento de elevada nobreza. Ali, ela aparece em meio a alegorias de coisas virtuosas e belas, boas ao ser humano. A relação da lira de arco com a antiga lira dedilhada grega é clara em meio ao pensamento renascentista e, assim, pode-se atribuir a ambas os mesmos valores simbólicos.

A lira da braccio e o lirone caíram em desuso durante o século XVII. Sendo assim, seguindo-se a tradição das substituições de um instrumento "antigo e desconhecido" por outro que fizesse mais sentido para o público de determinada época, na edição de 1709 do Iconologia temos junto ao "Deleite" um violino e junto à "Harmonia" uma viola-baixo.

Cítara:

A cítara é mencionada algumas vezes já nas primeiras publicações do Iconologia, em que se nota, numa mesma edição, o uso de diferentes nomes para designar o instrumento. Assim, Ripa indica os termos citara, cetera e cetra. Como nessas primeiras edições não há gravuras ilustrando as alegorias nas quais o instrumento é citado, torna-se mais desafiadora a tarefa de descobrir qual de fato seria a imagem da cítara presente na mente de Ripa, já que no século XVI, como indica Tyler (CITTERN, 2001), o instrumento mais comumente tido por "cítara" seria o de cordas de metal dedilhadas, mais próximo dos instrumentos parecidos com o violão, que "apesar de ter sido visto como uma clássica recriação da antiga kithara grega na 
cultura humanista do Renascimento Italiano", teve como seu precursor direto o citole medieval. $^{54}$

Tyler mostra também que o cittern (termo inglês que descreve o instrumento) foi "com frequência retratado num contexto clássico ou mítico" e que "a associação da cítara com educação, filosofia e ciência é mostrada em várias intársias italianas de finais do século XV e início do XVI"55, que bem poderiam ser conhecidos por Ripa. Portanto, se o autor do Iconologia preferiria ver suas alegorias representadas com antigas cítaras como as dos vasos gregos ou com o instrumento moderno que deveria conhecer e escutar permanece uma incógnita (ainda que haja uma aparente tendência no Iconologia ao uso do instrumentos modernos, como visto em relação às liras).

De qualquer modo, a mencionada representação do instrumento em contexto clássico ocorre de fato no Iconologia: uma das alegorias da "Música" a descreve como uma mulher que toca uma cítara que tem uma corda estourada, no lugar da qual vê-se uma cigarra, emulando, pois, a clássica história grega do tocador de cítara Eunomio. Narra o conto que, um dia, tocando em um concurso, Eunomio teve uma das cordas de sua cítara arrebentada. A fim de ajudá-lo, uma cigarra pousa sobre o instrumento e com seu canto substitui o som da corda estourada, dando ao músico a vitória no duelo musical. Esse mito grego não deveria ser estranho aos renascentistas, podendo ser encontrado também entre os emblemas de Alciato ${ }^{56}$.

Tamburo e Tamburino:

Instrumentos de percussão são pouco citados no Iconologia. Na edição italiana de 1625 tomamos conhecimento de dois: tamburo e tamburino. O primeiro figura em meio à "Monarquia mundana" e o segundo faz parte da alegoria que descreve a "Carruagem do Ar". Blades (1970, p.190, tradução nossa) afirma que "em todos os lugares e épocas, instrumentos de percussão foram usados para três propósitos

\footnotetext{
54 "Although it was regarded as a classical revival of the ancient Greek Kithara in Italian Renaissance humanistic culture, its direct precursor was the medieval citole."

55 "the instrument is often depicted in a classical or mythical context."; "The association of the cittern with learning, philosophy and science is shown in various intarsie of the late 15th and early 16th centuries."

${ }^{56}$ Curiosamente, a ilustração presente na edição de 1621 do Emblemata mostra uma cítara antiga.
} 
principais: cerimônias religiosas, sinais e encorajamento militares e para a dança" 57 . Como é possível supor, no Iconologia a percussão segue a tradição de seu uso em meio às alegorias das quais faz parte.

Por tamburo podemos tomar vários tipos de tambores. Segundo Blades,

entre os tambores usados [já] durante a Idade Média, encontramos muitos instrumentos que preenchem a lacuna entre o tronco de árvore coberto por uma pele do homem antigo e os instrumentos de percussão altamente desenvolvidos que associamos com a orquestra moderna. É durante o período medieval que conhecemos os nakers e os timbales de cavalaria que inspiraram os tímpanos orquestrais, e no tabor o antepassado da caixa militar e de nossa caixa orquestral moderna." (1970, p.204-5, tradução nossa) $)^{58}$

Seja qual for seu tipo, Ripa emprega o tamburo de forma bastante tradicional, próximo das trombetas, às quais normalmente associa-se desde antes do Renascimento. Frequentemente em conexão com atividades militares, o instrumento era indispensável na marcação dos ritmos de marchas, nos diferentes toques utilizados para a orientação dos soldados, etc.

Assim, o livro descreve a figura da Monarquia sentada sobre um globo terrestre, tendo a seu lado esquerdo "alguns prisioneiros com coroas nas cabeças, acorrentados e prostrados na terra com diversas armas ofensivas, trombetas, tambores, estandartes, coroas de diversos domínios, dinheiro, jóias, colares e outras riquezas" (1625, p.456, tradução nossa) ${ }^{59}$. Ele explica que isso representa o troféu da Monarquia, cujos súditos são os próprios reis "com seus despojos, riquezas e outras coroas de diversos domínios como sinal de Vitória e por ser Monarca e dominador de todo o Mundo" (1625, p.458, tradução nossa $)^{60}$.

Já o instrumento denominado tamburino surge em meio à alegoria da "Carruagem do Ar", ou seja, um "veículo" que carrega uma figura representando esse

\footnotetext{
57 "in all places and times, percussion instruments were used for three main purposes: religious cerimonies, military signals and encouragement, and the dance."

58 "Amongst the drums used during the Middle Ages we find many instruments that have bridged the gap between the skin-covered tree trunk of ancient man and the highly developed percussion instruments we associate with the modern orchestra. It is during the mediaeval period that we meet the nakers and the cavalry kettledrums which inspired the orchestral timpani, and in the tabor the forbear of the military side drum and our modern orchestral side drum."

59 "alcuni prigioni con corona in capo, incatenati, \& prostrati in terra con diverse arme offensive, Trombe, Tamburi, Insegne Stendardi, Corone di diversi dominij, Danari, Gioie, Collane, \& altre richezze." 60 "con le lor spoglie, \& richezze, \& altre corone di diversi dominij per segno di Vittoria, \& essere Monarca, \& dominatore di tutto il Mondo."
} 
que é um dos quatro elementos, com suas diversas características. É descrita como tendo na mão direita um raio e na esquerda um tamburino, que significa os "acidentes" que aparecem em meio ao ar, como chuva, trovões, neve, tempestades, etc. Tamburino, aqui, provavelmente designa um pandeiro. Blades (1970, p.196-7, tradução nossa) indica que "a popularidade do pandeiro foi sustentada ao longo da Idade Média em todas as partes da Europa" e que ele "é frequentemente ilustrado nas mãos de anjos, mas em muitos aspectos era tido como um instrumento rústico, associado a menestréis errantes, homens de espetáculos e malabaristas."61 No Iconologia, o pandeiro parece alegorizar as ditas intempéries devido à sonoridade chilreante ou retumbante que pode produzir.

É preciso mencionar, nesta pequena análise, a presença de instrumentos musicais junto à figura alegórica da "Música". A edição de 1593 (p. 173-5) já apresenta cinco descrições de possibilidades de representá-la, que são repetidas nas outras edições italianas aqui vistas. No entanto, nenhuma delas contém ilustrações para essa alegoria.

Das cinco mencionadas, três das descrições contêm instrumentos musicais. Numa delas, a Música, representada por uma mulher, segura com ambas as mãos uma "lira di Apolline" e aos pés tem diversos instrumentos musicais. Em outra, ela é uma mulher com um vestido "pleno de diversos instrumentos" e às mãos tem "uma viola da gamba ou outro instrumento musical". A terceira delas é aquela que porta uma cítara, mencionada anteriormente no trecho referente ao instrumento e que tem a seus pés, curiosamente, "uma lira com seu arco".

Mais uma vez é possível notar o alto valor seiscentista atribuído à lira e suas conexões com Apolo, já que ela aparece nas mãos da Música em uma das alegorias, enquanto que os outros instrumentos estão a seus pés. Por sua vez, quando a lira e seu arco estão aos pés da Música, essa toca a cítara, não menos ligada a Apolo. No geral, percebe-se uma tendência à representação da Música portando instrumentos de

\footnotetext{
61 "The popularity of the tambourine was sustained through the Middle Ages in all parts of Europe."; The tambourine is frequently illustrated in the hands of angels, but in many respects it was a rustic instrument, associated with wandering minstrels, showmen and jugglers."
} 
corda, o que também reforça suas conexões Apolíneas se levarmos em conta a antiga dualidade entre lira e aulos (cordas e sopros).

Das edições do Iconologia aqui consultadas, apenas a francesa de 1637 apresenta uma ilustração para a alegoria, como mostra a figura:

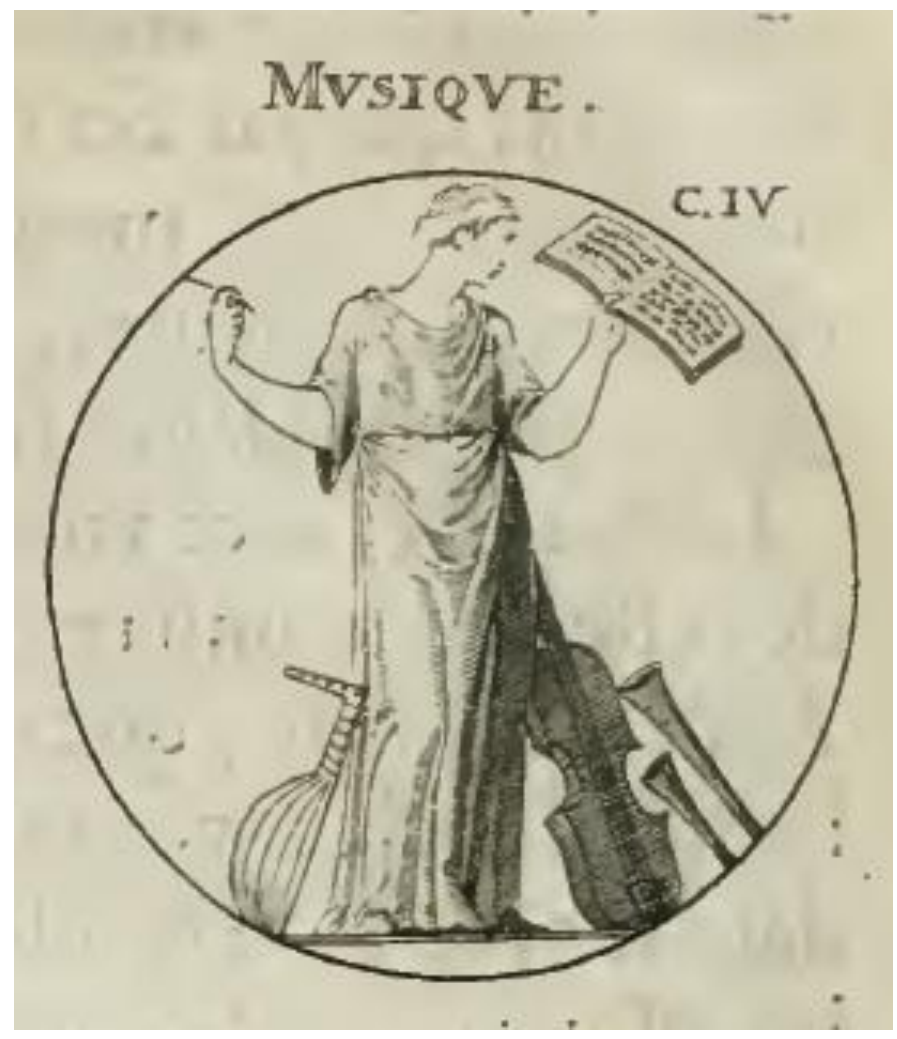

Fig. 22 - Alegoria da Música (RIPA, 1637)

Essa ilustração é também fruto de uma mescla de diferentes descrições da Música originalmente feitas por Ripa. A pluma e o livro de música que a figura ostenta fazem parte de uma representação e os instrumentos a seus pés, de outra.

Importante também é a presença das descrições das Musas gregas e do modo de representá-las graficamente que surge na edição de 1603 (p.345-51), na qual Ripa mostra seus nomes e seus atributos.

As nove deusas, filhas de Zeus e Mnemósine, eram para os gregos as inspiradoras das artes, literatura e ciências. Dentro de seus "domínios" específicos, algumas delas levavam instrumentos musicais que alegorizavam características de suas essências. 
Ripa descreve modos de se representar as Musas e em seguida mostra como elas estão figuradas em algumas obras de arte que nomeia. Em meio a essa informação, é por vezes possível distinguir os instrumentos musicais e suas funções alegóricas.

Clio, a musa "proclamadora" cujo domínio é a História, leva consigo uma trombeta "para mostrar os louvores que ela faz ressonar pelos feitos dos homens ilustres". Euterpe tem seus domínios na música e nos prazeres que ela proporciona aos homens, levando consigo "diversos instrumentos de sopro" (podendo figurar entre eles a tíbia e a flauta). Érato, a musa da poesia amorosa, leva consigo uma lira e um plectro. Terpsichore, inspirando os prazeres da dança, carrega uma lira com o plectro, uma cítara ou ainda uma harpa.

Comparando-se esse conteúdo ao que se vê ao longo do Iconologia, é interessante notar as semelhanças das "funções" desempenhadas por cada instrumento nos diversos aspectos que o livro aborda, o que evidencia a permanência de uma já mencionada tradição no modo de enxergá-los e utilizá-los nas artes. Assim, a trombeta sempre proclama com clareza novas para muitos ouvidos, as flautas e tíbias encantam, deleitam e distraem seus ouvintes e as liras soam segundo a beleza e perfeição daquilo que circunda Apolo e Orfeu. De uma forma ou de outra, mesmo que por vezes modificada ou ainda não tão clara, a visão alegórica aplicada aos instrumentos musicais, de maneira geral, se mantém ao longo do livro, mostrando-se quase sempre coerente.

Mesmo apresentando pouca profundidade em relação a aspectos mais especificamente ligados à música, o livro mostra claramente ou deixa pistas valiosas para o entendimento da concepção e aplicação artística renascentista dos "valores" extramusicais dos instrumentos. O conhecimento desses valores pode também auxiliar na compreensão de seu uso diretamente conectado ao fazer musical não só da época contemporânea a Ripa, mas também de períodos anteriores e posteriores. 


\subsection{Os instrumentos musicais e seu uso alegórico na prática musical}

O uso alegórico dos instrumentos musicais nas artes plásticas e na literatura, como exemplifica a análise anterior das descrições de Cesare Ripa, explicita ou sugere importantes pistas em relação ao modo como eram vistos e utilizados por suas potencialidades simbólicas. Abrangendo praticamente todos os diferentes campos das artes, esse modo de visão e uso dos instrumentos fez-se, logicamente, verdadeiro também para a música em si, em sua elaboração e prática, de forma significativa.

Desse modo, sendo a aplicação dos instrumentos como ferramenta alegórica potencializadora do discurso musical o principal foco deste trabalho, analisaremos aspectos do uso simbólico dos instrumentos musicais diretamente aplicados à música, buscando evidenciar seus empregos e significações dentro da atividade musical específica, na qual os instrumentos musicais e suas respectivas características encontram a forma ideal para o desempenho de suas potencialidades expressivas. Afinal, a prática musical sempre foi o principal motivo da existência dos instrumentos e é nela, numa mescla de sonoridade, aparência e tradição, que eles podem se apresentar em sua plenitude.

A partir de fins da Idade Média há uma maior quantidade de informações sobre a aplicação musical prática dos instrumentos como alegoria e através delas pode-se compreender com maior profundidade o modo pelo qual eles eram vistos, organizados e empregados segundo essa função.

\subsubsection{Classificações e agrupamentos}

Em meio à prática musical, nota-se uma relevante tendência histórica em diferenciar os instrumentos musicais, muitas vezes separando-os em grupos cujos membros apresentam determinadas afinidades em relação a vários aspectos, sejam eles sua construção e funcionamento, sonoridade ou ainda simbologia. Dos grupos 
instrumentais medievais aos modernos, essa distinção parece clara e o agrupamento de instrumentos "afins" pode ser encarado como uma constante através do tempo.

Uma das distinções mais antigas existente entre os instrumentos, muito influente no fazer musical europeu de fins da Idade Média e do Renascimento, diz respeito ao potencial sonoro dos mesmos, ou seja, à quantidade e volume do som que poderiam produzir. Como explica Baines (1991, p.230-231, tradução nossa):

Durante a era dos trovadores, instrumentos de sopro eram usados na música com grande liberdade. Há sugestões de segregação dos instrumentos mais ruidosos daqueles que combinavam melhor com os cantores e instrumentos de cordas, mas quase nada além disso. No entanto, no século XIV, com sua maior ênfase na música polifônica, a distinção tornou-se obrigatória $(. . .)^{62}$

A partir de fins do século XIII a classificação dos instrumentos como "sonoros" e "suaves" ou "altos" e "baixos" (mais próximos dos termos franceses haut e bas, frequentemente empregados nesse caso) torna-se importante na definição de suas funções e, logo, do tipo de música que executariam e a quais outros instrumentos seriam normalmente associados. Baines conecta essa questão à maior quantidade de instrumentos de origem árabe que passam a figurar na Europa na mesma época. Segundo o autor (1991, p.231, tradução nossa), entre eles encontravam-se

alguns dos principais instrumentos de corda da música de câmara árabe, como o alaúde, e o violino mourisco rubebe; também os instrumentos das bandas militares saracenas, com longos trompetes de metal, os pequenos tambores orientais nakers, e as charamelas de banda $(\ldots)^{63}$

Baines indica que, na Europa, "com o advento desses [instrumentos] veio também a estrita distinção oriental entre instrumentos e música sonora e suave",

\footnotetext{
62 "During the troubadour age, wind instruments were used in the music with great freedom. There are hints of segregation of the noisier instruments from those which matched the singer and strings, but hardly more. However, in the fourteenth century, with its great emphasis on concerted music, the distinction became binding (...)"

63 "some of the principal stringed instruments of Arab chambre music, as the lute, and the Moorish fiddle rubebe; also the Saracen military band equipment, with long metal trumpets, the small Oriental kettle-drums nakers, and the band shawm (...)"
} 
assim como é possível verificar na música tradicional do Oriente ainda nos dias de hoje.

Brown e Polk (ALTA, 2001) explicam que entre os instrumentos mais sonoros, ou haut, encontravam-se "charamelas, sacabuxas, trombetas, tambores a assim por diante, enquanto que os instrumentos bas eram flautas doces, violas, fiddles, harpas, saltérios, etc" 64 . Vale ressaltar que, nesse caso, os termos "alto" e "baixo" indicam apenas o volume de som dos instrumentos, nada tendo a ver com sua extensão sonora ou com a altura das notas por eles produzidas.

Os instrumentos altos podiam com facilidade ser escutados ao ar-livre e, portanto, eram utilizados em ocasiões públicas e cerimoniais. Entre os séculos XIV e $\mathrm{XVI}$, bandas desses instrumentos (como por exemplo, os chamados pifferi em território italiano), eram formadas por sopros de madeira e metal, além de percussão. Baines (1991, p.232, tradução nossa) descreve uma banda da cidade de Pisa no ano de 1324 como sendo formada por um músico tocando a charamela, um percussionista e dois pares de trombetistas, explicando que, numa banda maior, "um tocador de gaita-defoles e outro de flauta-e-tambor (pipe-and-tabor), estando prontamente disponíveis, poderiam ser adicionados" e que "essas eram bandas militares no sentido moderno completo, tocando em funções estatais, cavalgadas, torneios e em batalha" 65 .

Com o tempo, essa mesma banda passa a ser utilizada também para outra importante função: acompanhar a dança. Baines (1991, p.232, tradução nossa) cita um trecho do poema francês Les Echecs amoureux, oriundo de fins do século XIV, onde lêse

Quando as pessoas querem dançar, ou organizar uma grande celebração, os instrumentos sonoros (haut) são tocados, pois sua grande sonoridade agrada mais aos dançarinos; entre eles incluem-se trombetas, tabors, nakers, pratos, gaitas-de-fole, charamelas e cornetos. ${ }^{66}$

\footnotetext{
64 "shawms, sackbuts, trumpets, drums, and so on, while the bas instruments were recorders, viols or fiddles, harps, psalteries, and so on."

65 "a bagpiper or a pipe-and-taborer, being readly available, might be added. These were military bands in the full modern sense, performing at state functions, cavalcades, tournaments and battles."

66 "'When people wish to dance, or to stage a grand celebration, the loud (haut) instruments are played, for their great noise pleases the dancers better; they include trumpets, tabors, nakers, cymbals, bagpipes, shawms and cornetts'."
} 
Para a música de interiores, ou de câmara, preferia-se os instrumentos ditos "suaves" ou "baixos". Além dos já citados, a flauta transversal, o órgão e outros instrumentos de corda e sopro, considerados de sonoridade doce e contida, encontravam-se entre os bas.

Essa separação entre os instrumentos parece ter sido seguida com rigor durante muito tempo. Isso ficará evidente até mesmo nas artes plásticas, como explica Baines:

\begin{abstract}
Da música suave, os instrumentos sonoros eram excluídos. Naquelas pinturas do século XV que mostram coros de anjos exibindo todo tipo de instrumento musical, suave ou sonoro, será quase sempre observado que os anjos com instrumentos sonoros - charamelas e trombetas - balanceiam-se em lados opostos da figura ou formam um grupo na parte de trás; a distinção entre bas e haut permanece tão evidente como sempre (1991, p.235, tradução nossa). ${ }^{67}$
\end{abstract}

A distinção dos instrumentos por volume sonoro tinha aplicação funcional muito evidente, refletindo-se diretamente em seu emprego musical. No entanto, a divisão haut e bas poderia trazer consigo também conotações simbólicas, como se verá adiante.

De forma detalhada, McGowan (1999) explica que os agrupamentos instrumentais haut e bas também traziam consigo, em fins da Idade Média, uma representação complexa de status social. Aos príncipes e outros nobres que mantinham os dois tipos de grupos de instrumentos em seu meio, haut e bas seriam arautos de dois importantes ideais da nobreza da época: a magnificência e a majestade.

Os conjuntos haut, ou alta, com todo sua pompa e potência sonora, ligavam-se à magnificência, ou seja, àquilo que simbolizaria e mostraria claramente o poder e a riqueza material do nobre que os possuía:

\footnotetext{
67 "From soft music the loud instruments were excluded. In those fifteenth-century paintings that show choirs of angels exhibiting every kind of musical instrument, soft and loud, it will nearly always be observed that the angels with loud instruments - shawms and trumpets - balance each other on opposite flanks of the picture, or form a group at the back; the distinction between bas and haut remains as evidente as ever."
} 
[O] desfile acompanhava todos os atos públicos de um potentado, nos quais o som, aparência e mesmo a mera presença de instrumentistas de madeiras e metais poderia ser empregada para elevar a imagem do patrono (...) A alta ocorre no fim do Medievo como uma personagem em um complexo teatro de poder, cuja presença e atividades artísticas sempre se relacionava com a figura de autoridade que ela invariavelmente acompanhava, e cuja autoridade ela servia para endossar. (McGOWAN, 1999, p. 213, tradução nossa) $)^{68}$

O instrumentos bas, usados na música intimista de dentro dos palácios, muitas vezes realizada pelos próprios cortesãos, conectava-se à majestade, que se referiria à nobreza de espírito, alta cultura, inteligência e bom-gosto. McGowan afirma:

\begin{abstract}
A harpa, o saltério e mais tarde o alaúde, com suas sonoridades pinçadas, tornaram-se os principais instrumentos amadores de basse musique dos séculos XIV e XV. O som gentil produzido pelos movimentos físicos pequenos e delicados do harpista é tão íntimo que seria difícil de interpretar-se erroneamente as intenções do intérprete honrado, que excluía as massas tão certo quanto a organizada suíte de quartos do palácio (...) O espaço privilegiado da recentemente instituída chambre à parer ou 'câmara de presença' servia bem à demonstração exclusiva da intimidade musical que poderia estender-se aos convidados honrados, e oferecia um novo espaço de interpretação para as atividades artísticas de prestígio da corte. (1999, p. 225, tradução nossa) ${ }^{69}$
\end{abstract}

\author{
O século XVI foi palco para a ascensão e desenvolvimento dos grupos \\ instrumentais que passariam a ser conhecidos como consorts. Edwars (2001, Grove, \\ Consort) define o termo como
}

um pequeno conjunto instrumental para tocar música antes de 1700 . 0 significado é frequentemente extendido para cobrir grupos de vozes com ou

\footnotetext{
68 "This pageant accompanied all public acts of a potentate, in which the sound, appearance and even the mere physical presence of pipers and brass play- ers could be employed to enhance the patron's image (...) The alta occurs in the late Middle Ages as a character in a complex theatre of power, whose presence and artistic activities defer always to the figure of authority that it invariably accompanied, and whose authority it served to endorse."

69 "The harp, psaltery and later the lute, with their plucked sonorities, became the principal amateur instruments of basse musique of the 14th and 15th centuries. The gentle tone produced by a harpist's small and delicate physical movements is so intimate that it would be difficult to misconstrue an honourable performer's intentions, which excluded the masses as surely as the organized suite of palace room (...) The privileged space of the recently instituted chambre à parer or 'presence chamber' was well suited to the demonstration of the exclusive musical intimacy that could be extended to honoured guests, and offered a new performance space for the court's prestige artistic activities."
} 
sem acompanhamento instrumental, e a palavra também é aplicada para a música em si. ${ }^{70}$

Como se vê, o mesmo termo poderia significar coisas distintas e a formação de um consort podia variar muito. De qualquer forma, dentro do interesse daqui, pensaremos nos grupos formados apenas por instrumentos.

Spitzer e Zaslaw (2004, p.30, tradução nossa) escrevem que

\begin{abstract}
a maioria da música instrumental dos séculos $\mathrm{XV}$ e XVI foi concebida para 'consorts', ou seja, grupos de instrumentos, frequentemente do mesmo tipo e soando em registros diferentes, um para cada parte. ${ }^{71}$
\end{abstract}

Essa descrição evidencia uma questão importante em relação à formação de alguns grupos instrumentais que viriam a se diferenciar relevantemente das formações medievais de haut e bas já mencionadas: a presença de instrumentos com características muito próximas, não só em relação ao volume de som que produziam, mas também à sua construção e tipo de sonoridade, ou timbre, que formavam de fato uma família, contando com membros construídos de forma similar, mas tamanhos diferentes, o que permitia um resultado sonoro muito homogêneo, abrangendo uma grande extensão grave-agudo. Desse modo, diversas famílias de instrumentos apresentavam a possibilidade de execução da polifonia da época com sonoridade muito uniforme, chegando assim mais perto da música vocal.

Apesar de apontar-se o século XVI como um período áureo dos consorts, o seu desenvolvimento já vinha acontecendo antes. Baines explica que "por volta de 1350, consorts de sopros começaram a aparecer, como o de três flautas doces, com frequência ouvido na corte Burgúndia do tempo de Dufay" (1991, p.235). O autor continua explanando que

\footnotetext{
70 "A small instrumental ensemble for playing music composed before about 1700 . The meaning is frequently extended to cover ensembles of voices with or without instrumental accompaniment, and the word is also applied to the music itself."

71 "Most fifteeth- and sixteeth-century instrumental music was conceived for 'consorts', that is groups of instruments, often of the same type but sounding in different registers, one on a part."
} 
com a ascensão da Escola Flamenca de composição, nossas quatro partes comuns surgiram - soprano, alto, tenor e baixo, com a última escrita até a região grave da clave de baixo. Para enquadrar-se a isso, o consort de quatro partes soprano-a-baixo teria crescido bruscamente durante o intervalo de 1460 a 1490, produzindo a flauta doce baixo, o consort de cromornes e outros novos instrumentos. (1991, p.236, tradução nossa) ${ }^{72}$

Assim, durante o Renascimento, conjuntos de instrumentos de mesma família seriam bastante comuns. Baines (1991, p.242, tradução nossa) explica que

uma vez que a música [instrumental] era selecionada de composições a várias vozes em idioma vocal, quase toda espécie de instrumento era construída em um tamanho soprano, um tamanho tenor (que também servia para a voz de alto) e um tamanho baixo, cada um combinado à extensão da parte vocal correspondente ao longo da composição. ${ }^{73}$

Curiosamente, algumas família de instrumentos chegavam a transpassar o limite soprano-baixo, possuindo mais de três membros diferentes que, por vezes, cobriam uma extensão sonora que poderia ir do sopranino ao contrabaixo.

Apesar da popularidade dos consorts de instrumentos "iguais", conjuntos formados por instrumentos de diferentes famílias, assim como os antigos grupos medievais, não deixaram de ser utilizados com frequência. Esses grupos, hoje normalmente nomeados "broken consorts", nunca deixaram de existir, perdurando ao longo do século XVI e parte do XVII. No entanto, mesmo em um broken consort podese dizer que os instrumentos eram reunidos a partir de algum tipo de afinidade, fosse ela puramente musical ou não.

Em relação à sua simbologia e uso alegórico, pode-se imaginar que os diferentes conjuntos de instrumentos também poderiam ser propagadores de aspectos extramusicais, assim como os instrumentos sozinhos. Aliás, um grupo de

\footnotetext{
72 "with the rise of the Flemish School of composition, our regular four parts came in - treble, alto, tenor and bass, with the last written down to the bottom of the bass stave. To fit these the four-piece trebleto-bass consort would have grown up roughly during the interval 1460-1490, producing the bass recorder, the consort of crumhorns and the other new instruments."

73 "Since the music was selected from part-music composed in a vocal idiom, almost every species of instrumnet was constructed in a treble size, a tenor size (which also did for alto) and a bass size, each matched in compass to the range of the corresponding voice part in the general run of compositions."
} 
vários deles poderia, inclusive, intensificar seu potencial alegórico, unindo as características de cada um de seus membros em prol da expressão de algum aspecto de maneira ainda mais convincente.

Em meio ao universo de possibilidades de escolha da instrumentação de uma peça proporcionado pela prática musical do Renascimento e início do Barroco, o cuidado através do qual as decisões de interpretação eram tomadas pelas músicos da época mostra que o decoro na escolha dos instrumentos não era de modo algum subestimado. Nesse contexto, Edwards afirma (CONSORT, 2001):

\begin{abstract}
Uma escolha rígida de um meio de execução é estranha à música do século XVII e anterior a ele, mas flexibilidade completa, desinformada de considerações históricas e práticas, pode igualmente conduzir a interpretações muito distantes do espírito no qual a música foi escrita. A função da música, ao invés da música em si, tendia a governar sua instrumentação, um aspecto importante sendo a natureza da ocasião na qual a música era tocada. No Colégio Jesuíta inglês em Saint Omer, na França, por exemplo, a música de violas era associada no começo do século XVII com o treinamento de jovens músicos; música de consorts mistos era efetiva para a recepção de convidados e pessoas de distinção, enquanto a música de instrumentos de sopro como o hautbois e as flautas doces era apropriada para a recepção de pessoas de alta posição social. No teatro, onde a música de consort era com frequência tocada, a instrumentação seria normalmente determinada pelas associações simbólicas de instrumentos particulares. Cordas, fossem violas ou violinos, representavam harmonia, unidade e concórdia; oboés tinham associações mágicas e eram com frequência requisitados para conexões com portentos do mal; o som suave de flautas transversais e doces, por vezes referido como "música de quietude", tendia a simbolizar a morte. ${ }^{74}$
\end{abstract}

Essa série de significações simbólicas citadas acima combina, aliás, fortemente com a aplicação alegórica dada por Ripa aos instrumentos.

\footnotetext{
74 "A rigid choice of performing medium is alien to 17th-century and earlier music, but complete flexibility, uninformed by historical and practical considerations, may equally lead to performances far removed from the spirit in which the music was written. The function of the music, rather than the music itself, tended to govern its instrumentation, an important factor being the nature of the occasion on which the music was played. At the English Jesuit college at Saint Omer in France, for example, the music of viols was associated in the early 17th century with the training of young musicians; mixed consort music was effective for the reception of guests and persons of distinction, while the music of wind instruments such as the 'hautbois' and the 'recorders' was suitable for the reception of people of high rank. In the theatre, where consort music was often played, instrumentation would often be determined by the symbolic associations of particular instruments. Strings, whether viols or violins, represented harmony, unity or agreement; oboes had magical associations and were often called for in connection with evil portents; the soft sound of flutes or recorders, sometimes referred to as 'still music', tended to symbolize death."
} 


\subsubsection{A Idade Média e o drama sacro}

Do Medievo ao início de século XVII é possível encontrar-se um repertório que evidencia a aplicação prática dos instrumentos musicais como ferramenta alegórica e retórica. Sobre essas obras, nas quais a música desempenha um papel importante, senão principal, há uma série de indicações que deixam claro o emprego dos instrumentos graças às suas possibilidades simbólicas, bem como a importância desse emprego em meio ao potencial expressivo e catártico dessas obras.

Os dramas sacros medievais mostram-se excelentes exemplos dessa questão, além de fornecerem informações sobre a simbologia dos instrumentos musicais através do olhar cristão do período. Caracterizando-se como representações teatrais litúrgicas com finalidade catequética e artística, essas peças eram normalmente escritas por autores ligados a ordens religiosas e tinham como inspiração as histórias bíblicas. Como comenta Bowles (1959, p.70-71), a partir do século XII essas representações, anteriormente confinadas aos limites da igreja e de seus serviços, começam a ganhar nova proporção, transformando-se em pomposos espetáculos populares realizados fora dos templos, chegando a empregar grandes elencos, cenários e maquinaria complexa. Seu sucesso continuará por muitos anos e, como afirma o autor, "em fins do século XIV essas representações dramáticas eram muito difundidas, particularmente na região de Paris, a cena de um notável desenvolvimento do drama sacro"75. Como é possível imaginar, a música fazia-se presente nesses espetáculos medievais com importância considerável e, mesmo que não conheçamos exatamente as obras musicais ali apresentadas, uma série de documentos descrevendo as representações nos mostram o tipo de música utilizada e também os instrumentos musicais ali empregados, claramente em função alegórica.

Ao falar-se no drama sacro medieval, é interessante voltar o olhar à maneira interpretativa através da qual os pensadores da época concebiam a alegoria, retomando a ideia da "Alegoria dos Teólogos" anteriormente explicada. Na Idade Média, diferentemente do Renascimento fortemente inspirado pelos antigos valores Clássicos, a já mencionada "Alegoria Hermenêutica" e sua maneira complexa de

\footnotetext{
75 "By the end of the 14th century these dramatic presentations were widespread, particularly in the environs of Paris, the scene of a remarkable development of sacred drama."
} 
enxergar e interpretar as sagradas escrituras e seus respectivos símbolos era muito

influente no pensamento de então. Bowles reflete sobre essa questão:

\begin{abstract}
Como uma comunidade Cristã, a Idade Média constantemente fazia-se ciente do drama e do simbolismo inerente em sua religião. Da época dos Padres da Igreja aos Escolásticos séculos depois, a crença prevalecia de que atrás de cada objeto ou evento concreto havia um significado escondido relacionado às Escrituras, a fonte básica do conhecimento humano. Com o crescimento da Escolástica esse conhecimento foi classificado e sistematizado, e por meio de símbolos o intangível tornou-se claro. $\mathrm{Na}$ verdade, o mundo físico não tinha realidade para o homem medieval exceto como um símbolo, uma sombra do verdadeiro e espiritual reinado além. 0 Escolástico do século XII Hugo de São Victor, oferecendo uma explicação do universo, escreveu que todas as coisas materiais tinham um significado espiritual mais profundo, assim como o corpo do homem existia por causa de sua alma; e que apenas uma interpretação alegórica da Bíblia revelaria seu verdadeiro significado. (1959, p.67, tradução nossa $)^{76}$
\end{abstract}

\title{
O autor também escreve sobre o nascimento do repertório de símbolos e
}

lugares-comuns, frutos da visão alegórica medieval, que se fariam presentes nas artes

da época:

\begin{abstract}
A interação entre alegoria e simbolismo impressionou a Idade Média como talvez nenhum outro elemento em sua composição. Ela desenvolveu-se num tipo de paixão pela qual cada faceta da vida e do pensamento era explicada. Tanto os comentários dos Padres da Igreja como os dos teólogos eram citados em todos os tipos de obras religiosas, de comentários bíblicos aos manuais de instrução popular. Em todas essas fontes, os significados ocultos dos textos eram cuidadosamente elucidados. A propagação dessas ideias foi um importante fator na formação de um vocabulário simbólico que se fez sentir no drama e na música litúrgicos. Assim, os mesmos homens da igreja que, guiados por essa herança comum de exegese, planejaram os esquemas iconográficos para a escultura e os vitrais, também influenciaram os fundamentos simbólicos e alegóricos do drama medieval. (BOWLES, 1959, p.68, tradução nossa) ${ }^{77}$
\end{abstract}

\footnotetext{
76 "As a Christian community the Middle Ages was constantly made aware of the drama and symbolism inherent in its religion. From the time of the Church Fathers to the Schoolmen centuries later, the belief prevailed that behind each concrete object or event lay a hidden meaning related to the Scriptures, the basic source of man's knowledge. With the growth of Scholasticism this knowledge was classified and systematized, and by means of symbols the intangible was made clear. Actually, the physical world had no reality to medieval man except as a symbol, a shadow of the real, spiritual realm beyond. The 12thcentury Scholastic Hugh of Saint Victor, in offering an explanation the universe, wrote that all material things had a deeper spiritual meaning, just as man's body existed for the sake of his soul; and that only an allegorical interpretation of the Bible would reveal their true significance."

77 "This interplay of allegory and symbolism impressed Ages as perhaps no other element in its make-up. It developed in a sort of passion by which every facet of life and thought was explained. The comments
} 
Aqui, vê-se a importância do medievo como formador de um vocabulário alegórico influente no pensamento artístico de sua época e também das posteriores.

Como mencionado, o catecismo era uma das mais importantes funções do drama sacro, sendo capaz de contar ao povo da época (cuja grande maioria não tinha acesso aos livros e à leitura) as histórias da Bíblia, fazendo-o refletir e compreender os significados ocultos das escrituras sagradas. Portanto, essas encenações adquiriam certo caráter didático, e os elementos nelas utilizados deveriam auxiliar na compreensão, por parte do público, de diferentes aspectos. Os instrumentos musicais poderiam fazer parte desses elementos, valendo-se de seu potencial alegórico, certamente reconhecido pelo público. Sobre essa questão, Bowles explica:

(...) afim de que o drama medieval assumisse o papel de libri laicorum, recursos especiais tinham de ser encontrados para lembrar o público dos significados por trás das histórias retratadas em palavra, cor e música. A solução mais óbvia era a ênfase no contexto espiritual da cena. $O$ caminho mais direto era colocar os comentários sobre os significados ocultos na boca de algum personagem específico da peça. Outra técnica era a utilização de algum artifício da produção, em que os participantes vestiam ou carregavam algo simbolicamente reconhecível. Além disso, pareceria natural que todos os homens da igreja, escritores e produtores conscientemente visassem a escolha das forças instrumentais mais auspiciosas para suportar o significado tipológico de passagens particulares a serem acompanhadas. Assim fazendo, eles utilizariam aqueles instrumentos cujos atributos simbólicos melhor servissem seus propósitos. O vocabulário geral do pensamento medieval tinha exercido uma forte influência tanto sobre os teóricos escrevendo sobre a prática instrumental como nos teólogos que especulavam sobre o caráter desses instrumentos, dando a eles um rico simbolismo derivado de obras anteriores e elaborados sobre uma tradição mantida por séculos. (1959, p.69-70, tradução nossa) ${ }^{78}$

of both the Church Fathers and the theologians were quoted in all kinds of religious works, from biblical commentaries to manuals of popular instruction. In all such sources, the underlying significance of the texts was carefully elucidated. The spread of these ideas was an important factor in the formation of a symbolic vocabulary which made itself felt in both liturgical drama and music. It follows that the same churchmen who, guided by this common heritage of exegesis, devised the iconographical schemes for the sculpture and stained glass, also influenced the symbolical and allegorical foundations of medieval drama."

78 "in order for medieval drama to assume the role of libri laicorum, special means had to be found to remind the audience of the deeper meanings behind the storied portrayals in word, color, and music. The most obvious solution was an emphasis of the scenes's spiritual context. The most direct way was to place comments upon the hidden meanings in the mouth of some particular character in the play. Another technique was the utilizaton of some production device, wherein the participants wore or carried something symbolically recognizable. In addition, it would seem natural that the churchmen, writers, and producers all conciously aimed at selecting the most auspicious instrumental forces to buttres the typological meaning of the particular passages to be accompanied. In doing so, they would call upon those instruments whose stabilished symbolic attrributes best served their purposes. The general symbolic vocabulary of medieval thought had exerted a strong influence upon both the theorists writing about instrumental practice and the theologians who speculated upon the character of these 
A partir de fontes primárias e secundárias é possível obter uma quantidade relevante de referências a respeito do uso dos instrumentos musicais como alegorias no drama sacro medieval. Reunindo informações provenientes de documentos antigos e modernos que descrevem diversas desses obras, como faz Bowles (1959), conseguese compreender o papel simbólico dos instrumentos quando utilizados nesse tipo de peça teatral.

Nota-se que uma grande quantidade de instrumentos poderia ser utilizada. Segundo os padrões de classificação medievais, tanto os sonoros quanto os suaves eram empregados em diferentes situações.

Nas recorrentes representações do céu cristão, os instrumentos de sonoridade delicada eram privilegiados. Ali, tornava-se clara a utilização dos instrumentos bas como alegoria do divino. Bowles (1959, p.74, tradução nossa) indica que "as instruções de cena indicavam que apenas os instrumentos suaves, ou bas tocavam ao redor do cenário do céu." 79

De forma muito relevante, os instrumentos de corda eram associados à figura de Cristo, e assim, "saltérios, vièles, harpas e alaúdes eram tocados quando Jesus falava (...)" (1959, p. 76, tradução nossa) ${ }^{80}$. Bowles fala sobre a profundidade religiosa dos significados atribuídos durante o medievo a alguns desses instrumentos, mencionando, por exemplo, que "o saltério simbolizava por sua forma o corpo de Cristo e por seu som o Reino dos Céus" e que "a associação da harpa (...) com os anjos encaixava-se com seu simbolismo latente" sendo que "Hugo de São Victor escrevera que a harpa prefigurava e simbolizava a cruz de Cristo" (1959, p.76, tradução nossa). ${ }^{81}$

Em meio aos instrumentos conectados ao divino, destaca-se a figura do órgão, que já mostra ali sua profunda associação simbólica ao religioso que perdurará por séculos, chegando aos dias de hoje:

instruments, giving them a rich symbolism derived from earlier works and elaborated upon in a tradition that continued unbroken for centuries."

79 "The stage directions indicate that only the soft-sounding, or bas instruments performed around the setting of inner heaven."

80 "Psalteries, vièles, harps, and lutes were played when Jesus spoke(...)"

81 "The psaltery symbolized through its form the body of Christ and throgh its sounds the Kingdom of Heaven."; "The association of harp (...) with angels fitted in with its latente symbolism. Hugh of Saint Victor wrote that the harp prefigured and symbolized the Cross of Christ." 
Do tempo da Origem (que referia-se ao órgão como "A Casa de Deus") a Tomás de Aquino esse instrumento foi reconhecido por escritores como um instrumento eclesiástico. O Papa Gregório, o Grande, representou o órgão com um símbolo da adoração a Deus. Assim, não é surpreendente encontrálo simbolizando o Paraíso no drama medieval. O órgão era tocado para o coro de anjos, anunciava aparições celestes, acompanhava discursos da Virgem, e era tocado quando um santo cantava. (...) Seus tubos de maior sonoridade, com seu "som de trovão", enfatizavam a voz de Deus, a descida do Espírito Santo e a ira divina. (BOWLES, 1959, p.75, tradução nossa) ${ }^{82}$

A flauta doce, a partir de suas antigas conexões com pastores e paisagens campestres, não raramente figurava em meio a cenas relativas ao nascimento de Cristo, tradicionalmente representadas em ambientação pastoril.

Reiterando sua condição tradicional de arautos, os instrumentos de sopro de metal eram responsáveis pela execução de fanfarras que tinham a finalidade de chamar a atenção do público para o início das representações. O autor observa que "uma fanfarra de trombetas, chamada na França le cri du jeu, convocava todos os cidadãos que gostariam de participar ou observar a produção" (1959, p.71, tradução nossa) $)^{83}$. Havia também procissões conduzindo os artistas até seus lugares no palco, acompanhadas por uma grande variedade de instrumentos, haut e bas, entre os quais o soar dos metais provavelmente prevalecia, trazendo pompa à situação e direcionando a atenção das pessoas. Ocasiões solenes, de cunho real ou militar, faziam uso constante dos metais. Bowles comenta que "trombetas ou buisines eram utilizadas para entradas solenes e régias e em coroações" e que "durante cenas de batalha tanto trombetas como clarins eram tocados para sinalizar ataques, retiradas e vitórias". De forma não menos importante, os instrumentos também eram com frequência utilizados em cenas do Julgamento Final descrito no Apocalipse.

Bowles (1959, p.77, tradução nossa) comenta que "seguindo o aperfeiçoamento de equipamento cênico no século XIV, o Céu e o Inferno passaram a

\footnotetext{
82 "From the time of the origin (who referred to the organ as "The House of God") to Thomas Aquinas this instrument was recognized by writers as na acclesiastical instrument. Pope Gregory the Great represented the organ as symbolic of the praise of God. Thus it is not surprising to find it symbolizing Paradise in medieval drama. The organ was played for the choir of angels, announced celestial appearances, accompained speeches of the Virgin, and was played when a saint sang (...) Its loudest pipes, with their "thunderous sounds", underline the voice of God, the descent of the Holy Ghost, and divine wrath."

83 "A trumpet fanfare, called in France le cri du jeu, summoned all the townsfolk who wished either to participate in or to observe the production."
} 
dominar as cenas" ${ }^{84}$ dos dramas. Na representação da sonoridade infernal, o uso dos instrumentos sonoros, haut, era frequente. "Sopros de metal, barris com pedras, tambores, e por vezes peças de artilharia forneciam o acompanhamento infernal" $\left(1959\right.$, p.78, tradução nossa) ${ }^{85}$. Outros instrumentos de percussão também poderiam fazer parte dessa música e, por vezes, esse tipo de cena poderia ser representada por ruídos e barulhos.

O uso de sinos durante o Te Deum que normalmente era entoado por todos os atores e músicos envolvidos no drama, encerrando a obra, também fazia-se alegoricamente importante, devido à simbologia envolvendo esses instrumentos no período. Afinal, "Gulielmus Durandus escrevera que o sinos proclamavam a Palavra de Deus a todo o mundo como o pregador proclamando as Escrituras". Além disso,

\begin{abstract}
o material durável do sino simbolizava a verdade dos Evangelhos, sua resistência mostrava a força Cristã, e suas cavidades internas (assim como a declaração de São Paulo, 'Eu me tornei o metal sonoro') tipificavam a boca do pregador, cuja língua, assim como os badalos, atingia todos os lados, proclamando as Escrituras. (BOWLES, 1959, p.83, tradução nossa) ${ }^{86}$
\end{abstract}

Percebe-se que o papel alegórico dos instrumentos musicais no drama sacro medieval apresentava relevância e adornava seu discurso, ajudando a torná-lo mais claro e expressivo e, consequentemente, a potencializar as impressões de seu público. Assim, é possível constatar o uso retórico dos instrumentos como alegoria poética em meio ao pensamento artístico medieval estruturado a partir de uma visão de mundo proveniente da alegoria hermenêutica.

O vocabulário simbólico medieval, todo fundamentado no pensamento religioso que imperava na época, situa os instrumentos como ferramentas da propagação da fé cristã, conectando-os fortemente às figuras e acontecimentos importantes para aquela doutrina. No entanto, a verificação das características

\footnotetext{
84 "Following the elaboration of scenic devices in the 14th century, Heaven and Hell came to dominate the stage setting."

85 "Metal pipes, barrels filled with stones, drums, and sometimes actual artillery pieces furnished the hellish accompaniment."

86 "The bell's durable material symbolized the truth of the Gospels, their hardness showed Christian fortitude, and their inner cavities (like Saint Paul's remark, 'I am become the sounding brass') typified the mouth of the preacher, whose tongue, like the bells' clappers, struck both sides, proclaiming the Scriptures."
} 
simbólicas dos instrumentos musicais pelo viés cristão pode conectá-los também, muitas vezes, a seus papéis alegóricos pagãos, provenientes da tradição cultural da Antiguidade. Muitos dos lugares-comuns tradicionalmente associados aos instrumentos, independentemente de épocas e doutrinas religiosas, se mantêm. No Renascimento, quando um vasto material cultural pagão proveniente das culturas antigas será colocado ao lado do Cristianismo no dia-a-dia do fazer artístico, os instrumentos musicais poderão, numa mesma época, mostrar sua essência simbólica de diferentes formas, de acordo com o ambiente no qual serão empregados pelos artistas.

\subsubsection{O Renascimento e os intermedii}

Grandes espetáculos musicais e cênicos do Renascimento, os intermedii florentinos criados em meio ao século XVI, graças a uma rica fonte documental que os descreve são outra importante fonte de informação a respeito do uso alegórico e retórico dos instrumentos musicais.

Funcionando como entreatos de obras mais extensas, como peças teatrais, os intermedii apresentavam "canções, música instrumental, cenários espetaculares, figurinos e efeitos especiais" (SPITZER e ZASLAW, 2004, p.37). Apesar de explicitarem aquilo que era costumeiramente feito em Florença, as características do uso dos instrumentos musicais nesses espetáculos podem ser vistas de forma abrangente, sendo que "suficiente [informação] sobre outras regiões está disponível para permitir a conclusão de que práticas iguais ou similares eram seguidas em todo lugar" (WEAVER, 1961, p.364, tradução nossa) ${ }^{87}$.

Referindo-se aos intermedii realizados em 1589 para celebrar o casamento de Ferdinando de Médici e Christine de Lorraine, particularmente bem documentados, Spitzer e Zaslaw explicam que os instrumentos musicais presentes na ocasião foram organizados a partir de três princípios: alternação de conjuntos, igual distribuição das partes e instrumentação simbólica.

\footnotetext{
87 "enough is available from other regions to allow the conclusion that the same or similar practices were followed elsewhere."
} 


\section{O primeiro deles regia o fato de que}

exceto pela sinfonia instrumental do começo do primeiro intermédio e o coro final que encerrava o último, o conjunto completo de (...) instrumentos nunca tocava junto. Ao contrário, ele era dividido em uma sucessão de subconjuntos que seguiam-se uns aos outros no palco. (...) Os intermedii eram, assim, tocados não por um só conjunto, mas por um caleidoscópio de conjuntos alternados, cujo som, tamanho, e aparência mudavam de acordo com o número de partes em cada peça e com os requisitos do drama. (SPITZER AND ZASLAW, 2004, p.38, tradução nossa) ${ }^{88}$

\section{O segundo princípio, de acordo com os autores, indicava que}

na maioria das canções e sinfonias instrumentais o número de instrumentos era um múltiplo do número de partes na textura polifônica. (...) Presumivelmente, os instrumentos tocavam um por parte juntamente ou em alternância com as vozes. (...) Em outros casos os instrumentos eram distribuídos em dois ou mesmo três em cada parte. (2004, p.38, tradução nossa) $)^{89}$

De acordo com o último, porém aqui mais significativo princípio,

a escolha dos instrumentos para os vários conjuntos dos intermedii florentinos era influenciada por uma tradição de estereótipos programáticos. Instrumentistas apareciam no palco como personagens; os instrumentos que tocavam e os sons desses instrumentos serviam uma função simbólica. (2004, p.39, tradução nossa) ${ }^{90}$

Esses três princípios eram muito provavelmente também seguidos nos outros eventos desse tipo, anteriores e posteriores.

\footnotetext{
88 "Except for the instrumental sinfonia at the beggining of the first intermédio and the final chorus at the end of the last, the full ensemble of (...) instruments never played together. Instead, it was broken down into a sucession of sub-ensembles, which followed one another onto the stage. (...) The intermedii were, thus, played not by a single ensemble but by a kaleidoscope of shifting ensembles, whose size, sound, and appearance changed according to the number of parts in each piece and the requirements of the drama."

89 "In the majority of songs and instrumental sinfonie the number of instruments was a multiple of the number of parts in the polyphonic texture. (...) Presumably the instruments played one on a part along with or in alternation with the voices. (...) In other cases the instruments were distributed two or even three on a part."

90 "The choice of instruments for the various sub-ensembles of the Florentine intermedii was influenced by a tradition of programmatic stereotypes. Instrumentalists appeared on the stage and in character, the instruments they played and the sounds of those instruments served a symbolic function."
} 
De forma mais ampla, Weaver (1961) aborda a aplicação dos instrumentos na música do século XVI e faz uma aprofundada descrição sobre o seu uso em diversos espetáculos como os intermedii, reforçando a importância de sua escolha nessas obras e refutando afirmações errôneas sobre a instrumentação dos conjuntos utilizados na música anterior ao século XVII como sendo desregrada e vulgar. A autor explica que "o fato dos intérpretes determinarem a instrumentação não necessariamente significa que a escolha dos instrumentos fosse não-artística e acidental” (1961, p.363, tradução nossa) $)^{91}$.

De forma similar a Spitzer e Zaslaw, Weaver (1961, p.363-364, tradução nossa) considera que a escolha da instrumentação no século XVI era igualmente governada por três considerações. A primeira seria "o arranjo necessário dos instrumentos a fim de se encaixarem ao corpo polifônico da música, seja em consorts [de instrumentos "iguais"] ou em combinações heterogêneas"92. A segunda teria a ver com a função da performance, sendo que

as diversões privadas dos nobres permitiriam apenas os instrumentos socialmente aceitáveis: violas, alaúdes, teclados e ocasionalmente flautas doces (...) Música processional, da mesma maneira, tinha suas convenções bastante práticas empregando percussão, trombones, trombetas e sopros de madeira. ${ }^{93}$

Segundo a terceira consideração, referente à sua aplicação simbólica e alegórica, "a seleção dos instrumentos para uso em música de representações era guiada pela adequação dos instrumentos a um texto, à ação de um drama sacro ou secular, ballet ou masque, ou ao tema de um tableau ou carruagem processional." ${ }^{94}$

Reiterando a importância dos conceitos que se formaram ao longo do tempo, o autor afirma que

\footnotetext{
91 "The fact that the performers determined instrumentation does not necessarily mean that the choice of instruments was artless and accidental."

92 "the necessary arrangement of the instruments to fit a polyphonic body of music, either in consorts or in heterogeneous combinations."

93 "The private diversions of the noblemen would have allowed only the socially acceptable instruments: viols, lutes, claviers, and occasionally recorders (...). Processional music likewise had its rather practical conventions employing percussion, trombones, trumpets, and pipes."

94 "the selection of instruments for use in representational music was guided by the suitability of the instruments to a text, to the action of a sacred or secular drama, ballet, or masque, or to the subject of a tableau or a processional chariot."
} 
a identificação de instrumentos específicos com sujeitos específicos era o produto de um acúmulo de tradições antigas. Poucas, senão nenhuma, das associações originaram-se durante o próprio século, mas a consistente aplicação das cores instrumentais para fins representativos, dramáticos e programáticos em uma prática instrumental suficientemente orquestral para permitir a continuação dessas tradições através da evolução da orquestra, é uma marca positiva da criatividade do século XVI. ${ }^{95}$

A respeito das temáticas normalmente presentes nos espetáculos seiscentistas, Weaver as divide em quatro categorias recorrentes, cada uma com suas características particulares que ditam, entre outras coisas, os padrões para a escolha dos instrumentos musicais utilizados. São elas: "olímpica", pastoral, infernal e marcial. Ainda que as mencionadas quatro categorias possam mesclar-se umas às outras, "os temas são suficientemente separáveis para permitir classificação tanto do assunto quanto da instrumentação" (1961, p.365).

A categoria "olímpica" era inspirada pela mitologia greco-romana e aquela que atingia proporções mais amplas nos espetáculos, em sua representação dos deuses e dos mitos antigos. Os instrumentos ali utilizados deveriam ressaltar, portanto, o aspecto elevado das personagens e eventos representados, bem como suas conexões com os nobres da época. Weaver explica que

\begin{abstract}
os importantes olimpianos representavam teatralmente a nobreza presente, que reivindicava uma descendência desonesta dos mesmos e a possibilidade de ofuscar seu brilho. Assim, os instrumentos nobres (a lista de Castiglione inclui alaúdes, violas e instrumentos de teclado) mais os instrumentos do estado (trombones e cornetos) predominavam, mas eram coloridos por instrumentos provindos do quattrocento: harpas, saltérios, liras e flautas doces. As palhetas plebeias eram banidas e mesmo a sanção bíblica não é o bastante para preservar a percussão. (1961, p.365, tradução nossa) $)^{96}$
\end{abstract}

\footnotetext{
95 "The identification of particular instruments with particular subjects was the product of an accumulation of ancient traditions. Few, if any, of the associations originated during the century itself, but the consistent application of the instrumental colors to representational, dramatic, and programmatic ends in an instrumental practice sufficiently orchestral to permit the continuation of these traditions throughout the evolution of the orchestra, is a positive mark of the creativity of the 16th century."

96 "The high Olympians represented theatrically the presente nobility, who claimed at once devious descent from them and the likelihood of eclipsing their brilliance. Therefore, the noble instruments (Castiglione's list includes lutes, viols, and keyboard instruments) plus the instruments of state (trombones and cornetts) predominate but are colored by instruments derived from the quattrocento: harps, psalteries, lyras, and recorders. Banished are plebian reeds, and even biblical sanction is not enough to preserve the percussions."
} 
Sobre a categoria pastoral renascentista, Weaver esclarece (1961, p.369, tradução nossa):

Os sons identificadores de conjuntos pastorais são dados mais comumente por instrumentos de palheta, ou seja, (...), cromornes, dulcianas e gaitas-defoles. No entanto, flautas doces e rabecas também são vistas como instrumentos rústicos e ocasionalmente substituem as palhetas. Cenas e carruagens pastorais variavam se o tema tratava exclusivamente de camponeses ou pastores mais idealizados ou se, misturados com ou substitutos desses mortais, havia sátiros, ninfas e possivelmente um ou dois deuses menores. ${ }^{97}$

Sobre o uso da flauta doce nessa categoria, o autor também considera, no entanto, que "ocasionalmente flautas doces foram usadas (...) durante o século XVI" mas que

não é comum preferir-se flautas doces para cenas pastorais até o advento da ópera, quando esses instrumentos tornam-se convencionais. Nomeando apenas alguns poucos, Peri, Cavalieri, Monteverdi e Francesca Caccini usaram um conjunto de flautas doces e continuo para acompanhar cenas pastorais. (1961, p.370, tradução nossa) ${ }^{98}$

Weaver caracteriza a categoria "infernal" como apresentando, comumente, música tocada por violas e trombones, combinados, em seus registros graves, afim de representar assuntos misteriosos ou horrendos. Assim, a orquestra infernal

distinguia-se da orquestra olímpica pela ausência de cordas dedilhadas e cravos (apesar de instrumentos de teclado poderem ser representados por órgãos) e mais frequentemente de instrumentos de sopro agudos. Ela se

\footnotetext{
97 "The identifying sounds of pastoral ensembles are supplied most commonly by reed instruments, that is, (...), cromornes, dolcians, and bagpipes. However, recorders and rebecs are also regarded as rustic instruments and occasionally replace the reeds. Pastoral scenes and chariots varied according to whether the subject dealt exclusively with peasants or more idealized shepherds or whether, mixed with or replacing these mortals, there were satyrs, nympphs, and possibly a minor god or two."

98 "Occasionally recorders were used (...) during the 16th century"; "it is not common to prefer recorders for pastoral scenes until the advent of opera, at which time these instruments became standard. To name only a few, Peri, Cavalieri, Monteverdi and Francesca Caccini all used an ensemble of recorders and continuo to accompany pastoral scenes."
} 
diferenciava dos grupos pastorais, por outro lado, pela ausência de palhetas e cordas agudas. (1961, p.370-371, tradução nossa) $)^{99}$

A música de temática marcial ficava a cargo de uma sinfonia guerresca, conjunto formado predominantemente por sopros de metal, mas que também podiam contar com sopros de madeira (como cornetos), além de percussão. As trombetas eram consideradas os instrumentos ideais para essa função, apesar de poderem ser, eventualmente, substituídas ou somadas a trombones. Weaver explica que o mencionado conjunto instrumental era "uma antiga instituição na história do teatro Italiano" e que

por volta da época da chegada da ópera veneziana, a sinfonia guerresca com trombetas estava firmemente consolidada. Ela aparece em obras de Cavalli, Monteverdi, Manelli, Cesti e outros. (1961, p.372-373, tradução nossa) ${ }^{100}$

Apesar de não considerá-las como uma categoria temática, Weaver fala ainda sobre as "paisagens marítimas" que, quando figurando nos espetáculos musicais, também apresentavam o uso de instrumentação simbólica: "Paisagens marítimas normalmente pediam pela flauta transversal como a cor predominante, com ou sem o apoio de trombones" (1961, p.373, tradução nossa) $)^{101}$. Todavia, a instrumentação poderia variar, sendo que, para o mesmo tipo de cena,

os franceses preferiam o corneto, que foi chamado pitorescamente de 'trompe des Dieux marins' em um ballet apresentado em Paris em 1559. Apesar disso, em paisagens marítimas envolvendo marinheiros, ao invés de ninfas aquáticas, tritões, etc., revertia-se para a instrumentação pastoral de palhetas, sem dúvidas por sua natureza supostamente popular e sem refinamento. (1961, p.373, tradução nossa) $)^{102}$

\footnotetext{
99 "It was distinguished from the Olympian orchestra by the absence of plucked strings and harpsichords (though keyboard instruments might be represented by organs) and most frequently of soprano wind instruments. It was distinguished from the pastoral groups, on the other hand, by the absence of reeds and high strings."

100 "By the arrival of Venetian opera, the trumpet sinfonia guerresca was firmly entrenched. It appears in works by Cavalli, Monteverdi, Manelli, Cesti, and others."

101 "Seascapes generally called forth the transversal flute as the dominat color, with or without the support of trombones."

102 "The French preferred the cornett, which was picturesquely named 'trompe des Dieux marins' in a ballet performed in 1559. However, seascapes involving sailors, rather than aquatic nymphs, tritons, etc., reverted to the pastoral instrumentation of reeds, doubtless for their supposedly popular and unrefined natures."
} 
Após todas essas descrições de temáticas e categorias, vê-se claramente, em meio à escolha da instrumentação dos grandes espetáculos renascentistas, uma grande semelhança com as "regras" de uso dos instrumentos nos dramas medievais sobre os quais se comentou anteriormente. Isso não é mera coincidência, e Weaver reitera que "tradições governando a seleção dos instrumentos [no século XVI] originou-se das práticas instrumentais alegóricas do drama medieval" (1961, p.365, tradução nossa) ${ }^{103}$. Desse modo, percebe-se novamente a continuidade do uso instrumental alegórico através da tradição simbólica dos instrumentos, que mesmo surgindo modificada ou transformada ao longo da história, de alguma forma, permanece recorrente, seja em meio ao universo cristão medieval ou ao mundo de mitos pagãos retomado pelo Renascimento.

\subsubsection{O século XVII, a ópera e o Orfeo de Monteverdi}

O início do século XVII traz consigo a nova forma de se pensar e fazer música sugerida pela seconda prattica. Esse novo estilo de composição propunha algo diferente da tradicional e complexa polifonia que predominara na música até o Renascimento. Grosso modo, a rebuscada textura composta pelo contraponto de diversas vozes tratadas da mesma maneira e consideradas de mesma importância, característica daquela que ficou conhecida por prima prattica, passa a dividir espaço com uma música de textura mais simples, na qual fica clara a importância geralmente dada para duas vozes específicas: uma voz aguda (soprano), de caráter solista, verdadeiramente acompanhada por um baixo. A simplificação da polifonia que gerou a monodia da seconda prattica possibilitou uma nova forma de expressão musical na qual um texto (tratando-se da música vocal, então considerada de maior valor artístico) poderia ser pronunciado musicalmente com maior clareza e inteligibilidade, além de poder ter seus affetti expressos com maior funcionalidade. Assim, não por acaso, a seconda prattica ganhará seu maior palco na ópera, que emerge das ideias da Camerata Fiorentina no mesmo período.

103 "Traditions governing the selection of the instruments stem from the allegorical instrumental practices of medieval drama." 
Nessa então novíssima forma de arte e entretenimento, os instrumentos musicais estarão logicamente presentes. No entanto, apesar da novidade do estilo musical e do espetáculo em si, a forma de pensamento das instrumentações continuará muito semelhante à renascentista. Nas primeiras óperas, os instrumentos serão agrupados e utilizados de forma parecida à dos intermedii.

Como visto, nas representações do Renascimento o grupo de instrumentos empregados numa obra (que poderia ser grande e variado) raramente tocava todo junto. Havia uma clara separação desses instrumentos em conjuntos com caraterísticas comuns e específicas, referentes à sonoridade e também à funcionalidade e simbologia.

No início da ópera, o princípio dos "conjuntos separados", como ponderam Spitzer e Zaslaw, estará fortemente presente. De maneira importante, a essencial presença do novo baixo continuo dará a ele um conjunto de instrumentos próprio. Os autores explicam:

\begin{abstract}
No século XVII vários instrumentos podiam tocar a mesma parte (particularmente aquela do baixo), mas o princípio de separação de conjuntos por tipos de instrumento ainda era válido. Os dois conjuntos mais característicos da primeira metade do século XVII eram conjuntos do continuo, formados por teclados e cordas dedilhadas, que acompanhavam os cantores, e grupos de cordas, que tocavam danças. Esses dois conjuntos eram administrativa e socialmente separados, com diferentes músicos e diferentes funções. Conjuntos do continuo e grupos de cordas eram por vezes combinados em óperas e outras produções dramáticas, mas normalmente alternavam ou invés de tocar a mesma música juntos. (2004, p. 30, tradução nossa) $)^{104}$
\end{abstract}

Apesar da escassez de informações sobre a instrumentação das obras de boa parte do século XVII e períodos anteriores, alguma referência pode ser pontualmente obtida a partir de partituras ou outros documentos da época. Leopold (1996, p.265,

\footnotetext{
104 "By the seventeeth century several instruments could play the same part (particularly the bass part), but the principle of separation of ensembles by instrument type still obtained. The two most characteristic ensembles in the first half of the seventeenth century were continuo ensembles of keyboard and plucked strings, which accompanied singers, and strings bands, which played for dancing. These two ensembles were administratively and socially separate, with different personnel and different functions. Continuo ensembles and string bands were sometimes combined in operas and other dramatic productions, but they usually alternated rather than playing the same music together."
} 
tradução nossa) ${ }^{105}$ comenta que "as poucas partituras sobreviventes do primeiro período da ópera não dão praticamente nenhuma informação a respeito do acompanhamento instrumental. A única excessão é o Orfeo de Monteverdi". De fato, essa obra tornou-se referencial em relação à questão da instrumentação graças a informações trazidas em sua primeira edição que, além de conter uma lista de instrumentos utilizados em sua primeira apresentação, também traz indicações de seu uso em algumas cenas da ópera, como explica Stubbs:

A partitura do Orfeo de Monteverdi, publicada pela primeira vez em 1609, relata o evento de sua primeira apresentação na corte de Mântua em 1607 (...) [No documento] nós não temos nada de natureza prescritiva, mas na lista orquestral e nas muitas indicações na partitura nos são dadas uma abundância de informações descritivas. Infelizmente, a descrição está longe de ser completa e nem a lista nem as indicações concordam entre si a respeito do número exato de instrumentos envolvidos. Mas, com essas questões à parte, temos muito a aprender com aquilo que está na partitura. (1994, p.92, tradução nossa) $)^{106}$

Spitzer e Zaslaw explicam a respeito dos grupos instrumentais separadamente utilizados:

No Orfeo de Monteverdi (...) o canto é acompanhado por teclados e alaúdes, enquanto que os ritornellos e danças são tocados pelo conjunto de cordas a cinco partes. Os sopros constituem um terceiro conjunto, novamente com sua própria identidade e organização, e novamente tratados pelos compositores como uma entidade separada. Por exemplo, as cenas no submundo do Orfeo de Monteverdi (...) são introduzidas por ritornellos tocados por trombones e cornetos. (2004, p.30, tradução nossa) $)^{107}$

\footnotetext{
105 "The few surviving scores from the early period of opera give practically no indication as to the instrumental accompaniment. The only exception is Monteverdi's Orfeo."

106 "The score of Monteverdi's Orfeo, first printed in 1609, records the event of its first performance at the Mantuan court in 1607 (...) so we have nothing of a prescriptive nature, but in the orchestral list and the many indications in the score we are given an abundance of descriptive information. Unfortunately, the description is far from complete, and neither do the list and indications agree with one another about the exact numbers of instruments involved. But, these quibbles aside, we have much to learn from what is in the score."

107 "In Monteverdi's Orfeo (...) singing is accompanied by keyboards and lutes, while ritornellos and dances are played by the five-part string ensemble. Winds constituted a third ensemble, again with its own identity and organization, and again treated as a separate entity by composers. For example, the underworld scenes in Monteverdi's Orfeo (...) are introduced by ritornellos played by trombones and cornetts."
} 


\author{
A partir das informações sobre os instrumentos na partitura do Orfeo fica \\ evidente o emprego alegórico dado aos mesmos na obra. Leopold (1996, p.267, \\ tradução nossa) comenta:
}

Monteverdi claramente fez distinção entre dois grupos de instrumentos, aqueles do submundo e aqueles do mundo dos vivos. Trombones muito certamente não foram incluídos no "tutto stormenti" do acompanhamento do coro nupcial. ${ }^{108}$

A autora também faz uma ligação entre a importância da variação das cores instrumentais, muito valorizada por Monteverdi, à questão alegórica dizendo que esta

\begin{abstract}
servia consistentemente a fins textuais extramusicais. Desse modo, ela seguia tradições datando do início do século XVI e algumas vezes até de antes. O fato de os trombones, cornetos e regal serem reservados ao submundo pode ser observado nos primeiros intermezzi ${ }^{109}$. Da mesma forma, o uso do alaúde caracterizando a Era de Ouro também tinha uma longa tradição. A harpa era o instrumento não só dos céus e do paraíso mas, como um instrumento do continuo, do feminino. ${ }^{110}$
\end{abstract}

Sobre a instrumentação dos conjuntos do continuo, Leopold a conecta aos mesmos preceitos:

A escolha da instrumentação do continuo é igualmente determinada por critérios textuais. Consideremos como exemplo o organo de legno, um instrumento que obviamente foi utilizado para descrever ambientações tanto do mundo dos vivos como do submundo. Ele era considerado um instrumento que permanecia entre as esferas. No entanto, ele carregava o estigma da morte. No mundo dos vivos o organo di legno é sempre ouvido quando a morte se aproxima - na entrada da mensageira de notícias ruins, ou quando Orfeo canta sua "Tu sei morta". No submundo o organo di legno fica disponível ao Orfeo vivo. Quando Orfeo está guiando Euridice de volta ao mundo dos vivos, ele canta seu recitativo ao som do cravo, do chitarrone

\footnotetext{
108 "Monteverdi clearly distinguished between two groups of instruments, those of the underworld and those of the world of the living. Trombones most certainly were not included in the "tutto stormenti" of the accompaniment of the wedding chorus."

${ }^{109}$ Os intermedii já mencionados.

110 "it consistently served extra-musical textual ends. It thereby followed traditions dating back to the early sixteenth century and sometimes even further. The fact that trombones, cornetts, and regal were reserved for the underworld can be observed in the earliest intermezzi. Likewise, the use of the lute to characterize the Golden Age also had a long tradition. The harp was the instrument not only of the heavens and of paradise but, as a continuo instrument, of women."
} 
e da viola baixo - exceto pelo breve momento no qual a morte surge irrevogavelmente, e quando Orfeo, após virar-se para trás, olha nos olhos de Euridice enquanto eles desfalecem na morte. (1996, p.267-8, tradução nossa) $)^{111}$

Em sua análise mais aprofundada dos instrumentos nos conjuntos do continuo em Orfeo, Stubbs (1994, p.92-6) propõe uma série de hipóteses através das quais a escolha da instrumentação e seu uso na ópera de Monteverdi poderiam ter sido pensados pelo compositor. Entre elas encontra-se a possibilidade do uso de um instrumento ou grupo de instrumentos do continuo a partir da associação direta a um papel ou personagem da ópera; outra relaciona-se à escolha da instrumentação para representar um affetto específico; há também a chance do uso dos instrumentos para a representação de lugares e criação de atmosferas e finalmente, a questão da associação direta dos instrumentos à simbolismos tradicionais.

É possível pensar que em todas essas categorias, os instrumentos atuam como alegorias. Apesar de Stubbs debater a questão da simbologia como uma possibilidade específica da seleção dos instrumentos, ela pode ser encontrada também nos outros parâmetros de escolha da instrumentação, uma vez que a relação de um instrumento a uma personagem bem como a criação de atmosferas e menção a lugares também pode apoiar-se em aspectos simbólicos tradicionalmente ligados aos instrumentos.

As figuras a seguir, retiradas da primeira edição do Orfeo de Monteverdi, datada de 1609, mostram a lista dos personagens e dos variados instrumentos utilizados na ópera e também alguns trechos da partitura nos quais há indicação de instrumentação:

\footnotetext{
111 "The choice of the continuo instrumentation is determined equally by textual criteria. Consider as an example the organo di legno, an instrument that obviously was used to depict moods in both the world of the living and the underworld. It was considered an instrument that stood between the spheres. However, it carried the stigma of death. In the world of the living the organo di legno is always heard when death approaches - at the entrance of the bearer of ill tidings, or when Orfeo sings his 'Tu sei morta'. In the underworld the organo di legno is made available to the living Orfeo. When Orfeo is leading Euridice back to the world of the living, he sings his recitative to the sounds of the harpsichord, the chitarrone, and the bass viol - except for the brief moment when death appears irrevocably, and when Orfeo, after turning back, looks into Euridice's eyes as they grow faint in death."
} 


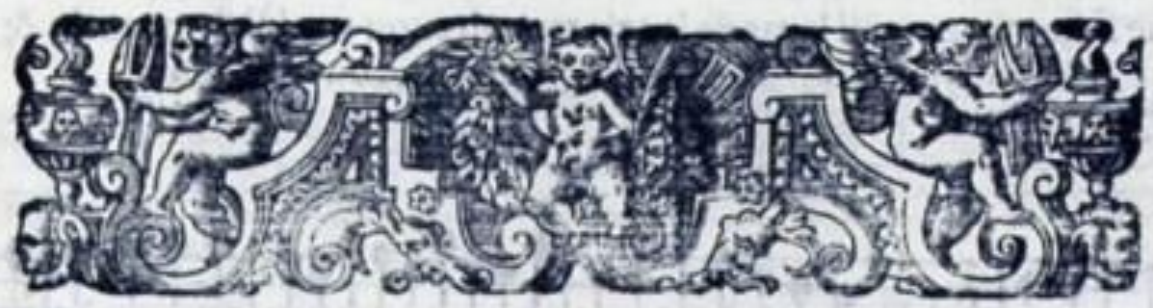

PERSONAGGI.
STROMENTJ.
La Mufica Prologo.

Orfeo.

Euridice.

Chore di Ninfe, e Paftori.

Speranza.

Caronte.

Choro di Spiriti infernali.

Proferpina.

Plutone.

Apollo.

Choro de Paftori che fecero la moref ca nel fine.
Duoi Grauicembani.

Duoi contrabaff de Viola.

Dieci Viole da brazzo.

Vn Arpa doppia.

Duoi Violini piccoli alla Francese.

Duot Chitaroni.

Duoi Organi di legno.

Tre bajfle da gamba.

Quattro Trombeni.

$V_{n}$ Regale.

Duoi Cornetti.

$\nu_{n}$ Flautino alla Digefima feconda

$V_{n}$ Clarino con tre trombe fordine,

Fig. 23 - Personagens e instrumentos musicais para a representação do Orfeo (MONTEVERDI, 1609) 


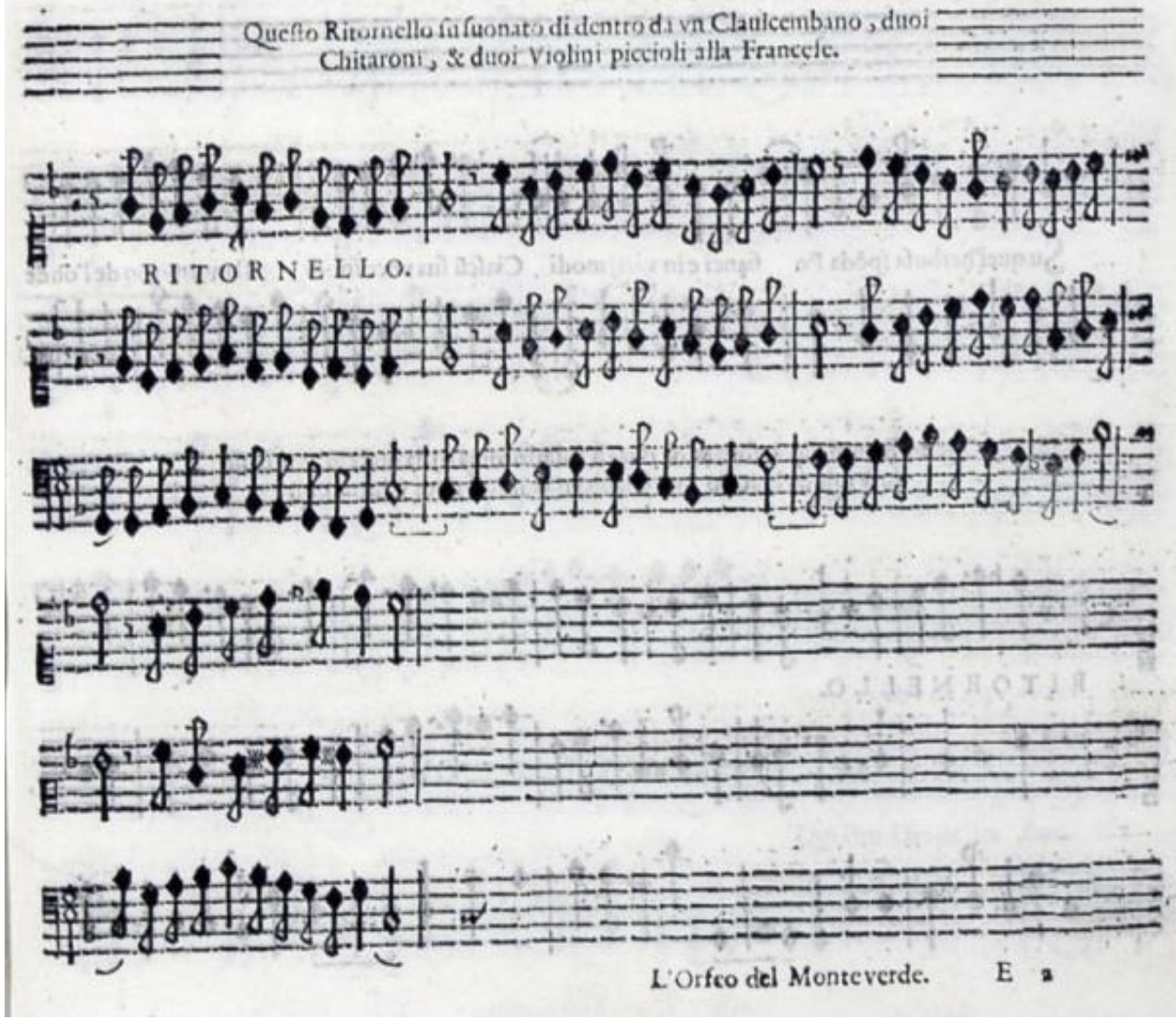

Fig. 24 - Ritornello do início do segundo ato do Orfeo. A partitura indica: "Este Ritornello foi tocado de dentro [da cena], com um Clavicembalo, dois Chitaroni e dois Violini piccoli alla Francese.

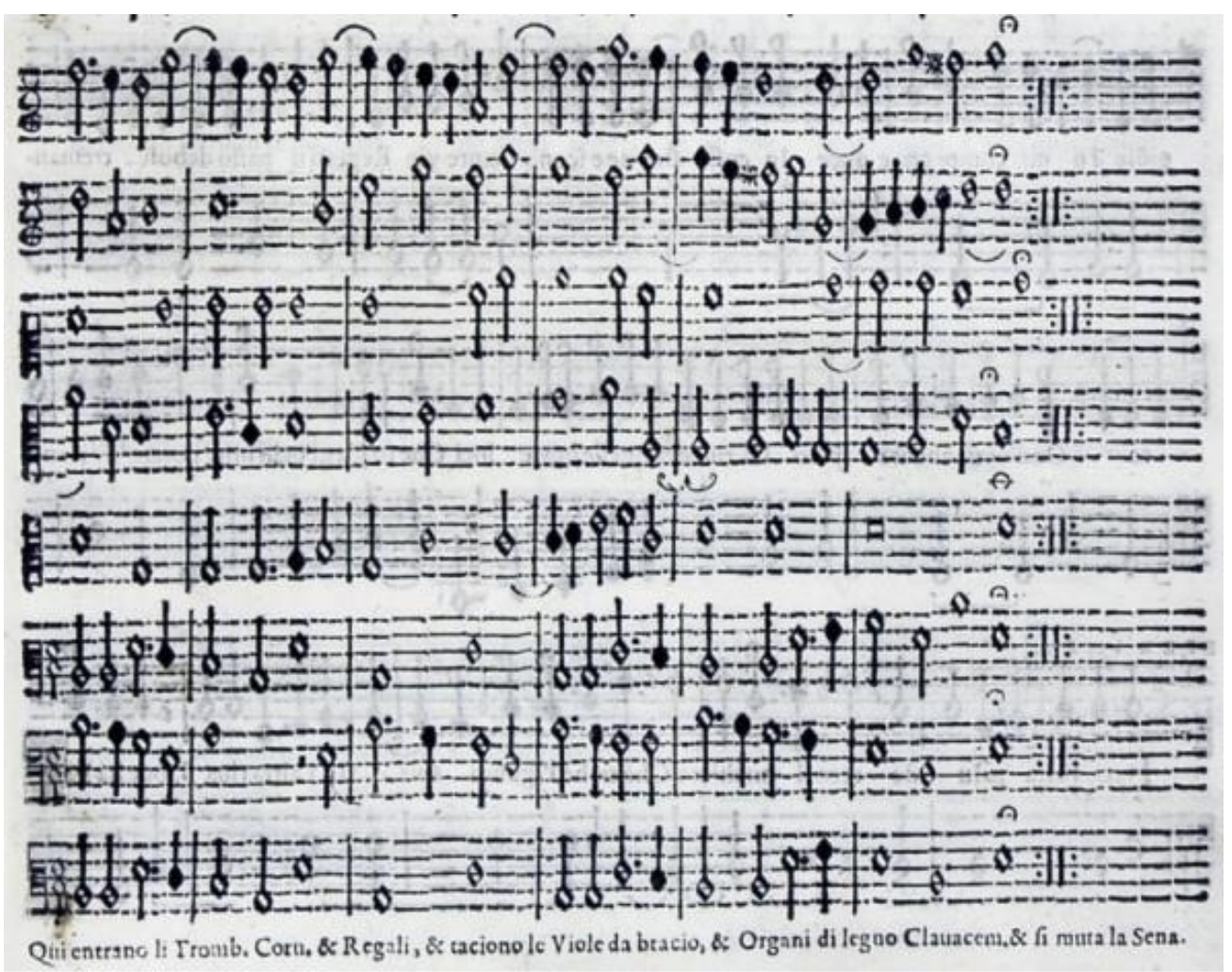

Fig. 25 - Trecho da Sinfonia do terceiro ato do Orfeo, que anuncia a instrumentação do "submundo". Abaixo do trecho musical lê-se: "Aqui entram os Tromboni, Cornetti e Regali, e silenciam as Viole da braccio, Organi de legno, Clavicembalo e muda-se a Cena." 


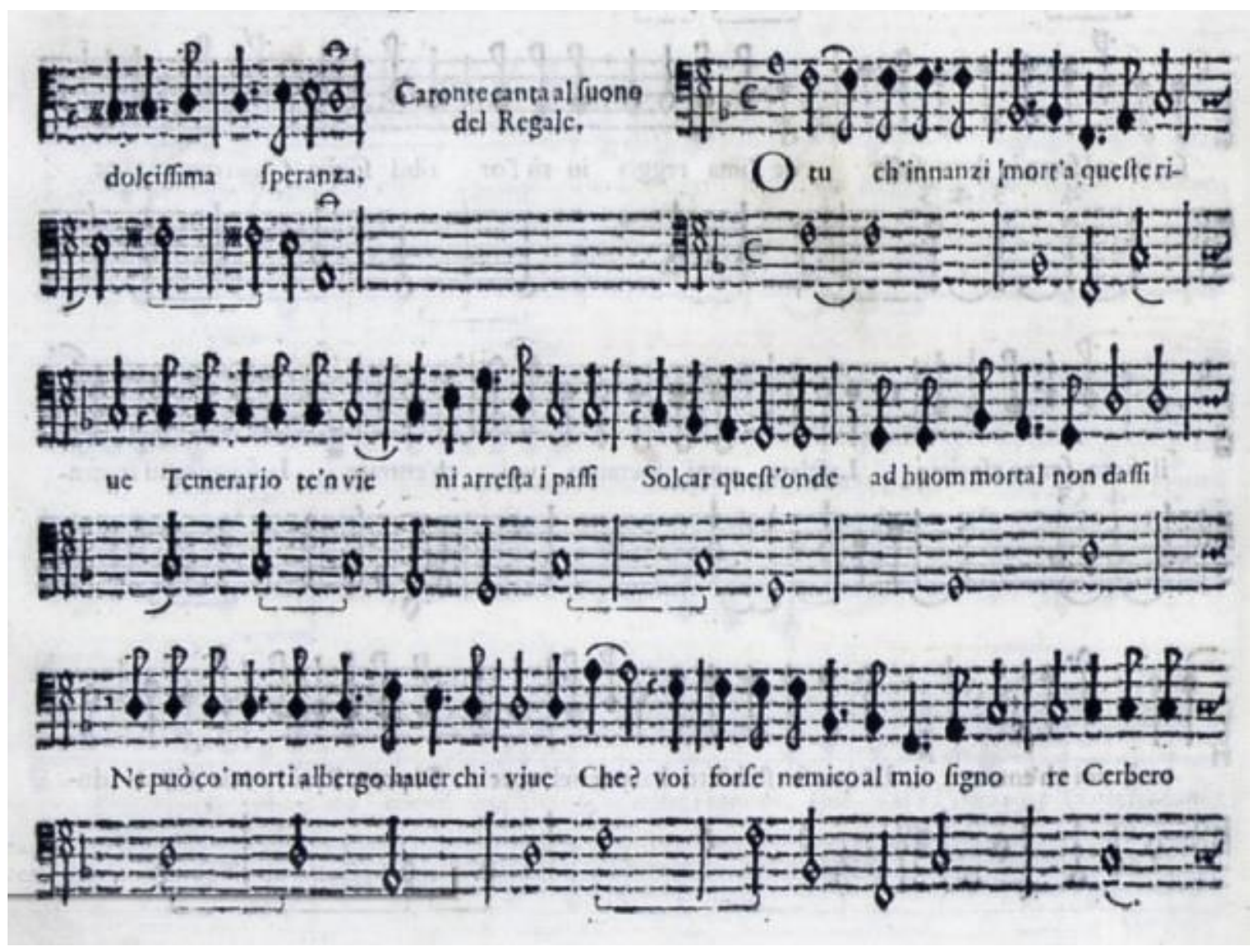

Fig. 26 - Início do cântico da personagem Caronte, no terceiro ato do Orfeo. Nota-se a inscrição "Caronte canta ao som do Regal"

A partir das análises aqui realizadas, nota-se, da Idade Média ao século XVII, uma preocupação de compositores e intérpretes com a instrumentação das obras musicais (o que mostra que os conjuntos instrumentais da época estavam muito longe de ser um mero acúmulo de instrumentos disforme e sem sentido). Em meio a essa preocupação, vê-se que um dos principais aspectos da escolha da instrumentação e sua aplicação na música do período dizia respeito ao seu uso alegórico, tendo os instrumentos como representantes de questões extramusicais, e que isso era vislumbrado como uma condição artisticamente relevante e que apresentava possibilidades de enriquecimento expressivo das obras. Tal relevância mostra-se viva também em períodos seguintes, já que o uso alegórico dos instrumentos permanecerá como parte da atividade musical ainda por muitos anos, praticamente durante todo o tempo no qual a retórica ditou suas regras às artes, por vezes até mesmo transpassando essa época e reaparecendo de outras formas no futuro. Reforçando 
essa afirmação, Spitzer e Zaslaw dirão que "a instrumentação simbólica não desapareceu com o advento da orquestração 'barroca': Monteverdi, Gluck, e Haydn usaram trombones para sugerir o submundo; de fato, assim o faz Stravinsky em seu ballet Orphée (1947)." (2004, p.31, tradução nossa) $)^{112}$

112 "Symbolic instrumentation did not disappear with the advent of 'Baroque' orchestration: Monteverdi, Gluck, and Haydn all use the trombone to suggest the underworld; indeed so does Stravinsky in his ballet Orphée (1947)." 


\section{O SÉCULO XVII E IMPORTANTES ACONTECIMENTOS ORGANOLÓGICOS}

O capítulo anterior comentou a respeito do significativo uso dos instrumentos musicais e seus simbolismos como ferramenta retórica em obras do início do século XVII. Esse período, no entanto, é deveras importante em meio à história dos instrumentos no Ocidente moderno, por ter sido palco para acontecimentos-chave no desenvolvimento de sua construção e também de sua aplicação no repertório daquela época, bem como de posteriores. Sendo assim, é possível apontar diversos acontecimentos organológicos muito relevantes ocorridos durante o Seicento, em relação a aspectos como seleção, construção e usos (dentre os quais, o simbólicoretórico).

Não é exagero referir-se à transição do final do século XVI para o início do XVII, do Renascimento para o primeiro Barroco, portanto, como uma verdadeira revolução no meio musical, devido às grandes mudanças estruturais e também de pensamento e concepção dessa forma de arte ocorridas no período. De certo modo, poderíamos dizer que tal transformação, em meio a suas características e consequências "revolucionárias", só tenha tido paralelo na história da música ocidental moderna com a nova música atonal proposta por alguns compositores na virada do século XIX para o $\mathrm{XX}$ (quando a forte e então dominante estética representante do ultra-romantismo europeu passa a dividir espaço com as novas sonoridades do impressionismo francês e do dodecafonismo alemão). Salvas as devidas proporções dentro dessa comparação, o início do século XVII trouxe consigo, assim como as mencionadas correntes pósromânticas, uma forma totalmente nova de se pensar e fazer música, forma essa que praticamente rompia com a tradição musical secular vigente até então.

Como dito, aquela que ficaria conhecida como prima prattica composicional foi suplantanda por uma seconda. A primeira delas, dominante desde centenas de anos antes, era principalmente caracterizada por uma complexa textura polifônica cujas diversas vozes eram tratadas igualmente, com mesma relevância, construída em meio a uma série de regras notavelmente restritas. O resultado musical consistia num incrível e intricado contraponto, quase sempre de caráter contemplativo e de certo modo "estático", que com sua sonoridade representava muito bem os ideais de perfeição e as "proporções divinas" buscadas pelos artistas medievais e renascentistas. 
Logicamente, a música da prima prattica apresentava muitas outras características que se fizeram presentes e que por vezes também se transformaram ao longo do tempo no qual ela esteve em voga (e que aqui não são o foco) mas, apesar das distinções que podem ser feitas em relação aos diferentes períodos nos quais ela foi praticada e também às diferentes escolas de composição que a ela se dedicaram, de forma geral, é possível dizer que sempre manteve as citadas características (que podem ser encontradas, por exemplo, em obras de Phillippe de Vitry, passando por Machaut, Dufay, Josquin des Prez e alcançando os Gabrieli em Veneza). É preciso mencionar que a música de estilo baixo, como parte daquela que fazia uso de textos profanos ou ainda aquela puramente instrumental (a música de dança) caminharam em direção ao início do Barroco seguindo tendências ao uso de texturas contrapontísticas mais homofônicas e menos rebuscadas, enquanto que a sacra, de estilo alto, mesmo após a imposição contra-reformista dos ideais de "simplificação" da música em favor de uma maior inteligibilidade textual, conservou sua complexidade textural. Entretanto, mesmo a música homofônica manteve o característico tratamento igualitário da vozes.

A seconda prattica rompe com boa parte das características da prima. Os novos valores artísticos surgidos em meio aos estudos clássicos dos intelectuais da Florença do final do Renascimento trouxeram consigo uma nova concepção daquilo que deveria ser a música do homem moderno, ou le nuove musiche, tal qual o título da obra de Giulio Caccini, publicada em 1601, que contém música composta nesse novo estilo. 0 contraponto complexo é então abandonado em favor da monodia, na qual, basicamente, uma voz, considerada de maior importância ou ainda a principal, é de fato acompanhada por uma linha de baixo. Há, portanto, uma hierarquização das melodias anteriormente inexistente. Da citada linha de baixo que acompanha a voz terá início a importantíssima prática do baixo-contínuo, que permanecerá presente em toda a música europeia produzida pelos próximos cento e cinquenta anos, ao menos, e que será uma das maiores características musicais do extenso período mais tarde chamado de Barroco.

Sachs (1940, p. 351, tradução nossa) descreve a intensidade da introdução da nova prática musical:

Uma revolução radical irrompeu no início do século XVII. Nunca antes os compositores haviam enfatizado o contraste ao estilo antigo com a mesma 
determinação, de fato arrogância. Nunca antes haviam colocado a novidade do seu estilo com tamanho empenho. ${ }^{113}$

O caráter monódico da nova música cumpria perfeitamente seu dever de deitar ao público um texto que poderia ser totalmente inteligível ao espectador enquanto cantado. Além disso, o modo de se musicar um texto estava plenamente fundamentado na ideia de potencializar seus affetti. Essa parece ter sido a condição primordial da composição na seconda prattica, que, a favor da explicitação retórica dos sentimentos humanos estava disposta a voluntariamente quebrar regras de construção musical há muito estabelecidas (como aquelas em relação à harmonia, à forma, etc). Mesmo podendo chocar os ouvidos contemporâneos, a nova música assim o faria em prol da expressão do texto. Sobre esses aspectos, explica Sachs:

\begin{abstract}
A nova geração buscava fortes emoções; ela tentava apelar aos corações dos ouvintes. (...) Os compositores representavam sentimentos humanos com um fervor que resultava na completa ilusão do espectador. Padre Mersenne relata que os cantores italianos dessa época expressavam paixões tão violentamente que o público acabava por achar-se ele mesmo envolvido; e quando, em uma ópera de Monteverdi encenada em 1608 na corte de Mântua, Arianna, abandonada por Theseus, cantou seu comovente lamento, os ouvintes irromperam em lágrimas. (SACHS, 1940, p. 351, tradução nossa) $)^{114}$
\end{abstract}

O autor continua diferenciando os estilos novo e antigo, como comentado anteriormente, relatando também a urgência da criação da ópera dentro da nuove musiche (1940, p. 351, tradução nossa):

(...) o madrigal lírico do século XVI foi necessariamente suplantado pelo drama musical. Essa mudança envolveu outro contraste. A Renascença, prezando pelo equilíbrio, deu igual peso a todas as vozes, do soprano ao

\footnotetext{
113 "A radical revolution in music broke out at the opening of the seventeenth century. Never before had composers emphasized the contrast to the old style with the same decisiveness, indeed arrogance; never before had they laid stress on the novelty of their style with similar determination."

114 "The new generation strove for strong emotion; it tried to appeal to the listeners' hearts. (...) Composers represented human feelings with a fervor resulting in the complete illusion of the hearer. Father Mersenne relates that Italian singers of his time expressed passions so violently that the audience would think they themselves were involved; and when, in an opera by Monteverdi performed in 1608 at the Mantuan court, Arianna, forsaken by Theseus, sang her heart-rendering lament, the listeners burst into tears."
} 
baixo. Por volta de 1600, os compositores estabilizaram a prevalência de uma das partes. $O$ estilo polifônico foi substituído por um estilo monódico, mais capaz da expressão da mente e das emoções do homem. ${ }^{115}$

É claro o fato de que a seconda prattica nasceu diretamente vinculada à música vocal, como é explicitado pela grande preocupação dos compositores da época com o uso de um texto e de seu enorme esmero na tentativa de transmissão de seus significados afetivos ao público da forma mais clara possível. No entanto, a nova música virá a influenciar diretamente também a música instrumental do período e isso terá consequências muito significativas em relação ao uso dos instrumentos musicais.

O início do século XVII vê o surgimento de um novo repertório puramente instrumental, muito diferente daquele produzido até então, no qual os ideais da seconda prattica se fazem fortemente presentes. Assim, a música instrumental que começa a ser composta no período vai além de danças, de diminuições de motetos e outras obras vocais e de peças polifônicas que basicamente formavam o repertório dos instrumentistas daquele período. As composições instrumentais no novo estilo mesclam as características declamatórias da nova música vocal com as possibilidades idiomáticas de cada instrumento.

Para que tivesse efeito, o novo estilo exigia que os instrumentos conseguissem ser tão expressivos como as vozes e que pudessem, como elas, verdadeiramente cantar. Essa necessidade de expressão resultou no que podemos chamar de uma espécie de "seleção" dos instrumentos musicais munidos de tal capacidade. Sachs explica:

O estilo polifônico utilizara instrumentos e vozes dentro da extensão de apenas uma décima, a fim de evitar interferências nas partes vizinhas; a nova monodia, ao contrário, requeria uma ampla extensão para expressar paixão e mudanças repentinas da alegria ao pesar, da melancolia à exultação. (...) Os instrumentos tiveram de passar por um severo processo de seleção. Apenas puderam ser mantidos aqueles que tinham uma extensão suficientemente ampla e flexibilidade o bastante para dispor de todas as gradações de dinâmica, do pianíssimo ao fortíssimo; esperava-se

115 “(...) the lyric madrigal of the sixteenth century was necessarily superseded by the musical drama. The Renaissance, aiming at equilibrium, had given equal weight to all parts, from the treble to bass. At about 1600 , composers re-estabilished the prevalence of one of the parts. The polyphonic style was replaced by a monodic style, which was better able to express man's mind and emotion." 
dos instrumentos que cantassem como os seres humanos. (SACHS, 1940, p. 351-352, tradução nossa) $)^{116}$

Portanto, características como uma suficiente extensão sonora grave-agudo e a possibilidade de entonação de diferentes dinâmicas, além de outras sutilezas, passaram a ser vistas como condições essenciais para que um instrumento musical fosse suficientemente expressivo na imitação da voz e, consequentemente, capaz de realizar a nova música de forma satisfatória. Esse fato provocou a elevação musical e social de alguns instrumentos, bem como o gradual desaparecimento de outros.

A passagem do Renascimento para o Barroco trouxe consigo uma grande variedade de instrumentos musicais até então em pleno uso em meio a suas diferentes funções, como atesta Michael Praetorius na segunda parte de seu importante tratado Syntagma Musicum, dedicada aos instrumentos. Publicada em Wolfenbüttel em 1618 e 1619, em pleno florescimento da nova música, o documento nomeado De Organographia é um dos mais importantes dentro do estudo da organologia, por relatar com clareza o uso dos instrumentos na prática musical da época, além de detalhar características de sua construção (informações essenciais na compreensão dos instrumentos antigos, de seu funcionamento e da maneira como eram utilizados). O documento conta ainda com uma monumental Sciagraphia, publicada em 1620, formada por diversas xilogravuras representando detalhadamente os instrumentos musicais, incluindo suas dimensões métricas.

A publicação de Praetorius que, nas palavras do próprio autor, apresenta "uma descrição dos instrumentos musicais usados hoje, com seus nomes e classificação" (PRAETORIUS, 1986 [1619], p. 21, tradução nossa) ${ }^{117}$, é prova da relevante quantidade de diferentes tipos de instrumentos conhecidos e utilizados na época. As xilogravuras mostram ainda que grande parte de cada tipo de instrumento era comumente construída em diferentes tamanhos, formando os conhecidos consorts de

\footnotetext{
116 "The polyphonic style had utilized instruments and voices within the compass of a tenth only, to avoid interference of neighboring parts; the new monody, on the contrary, required a wide range to express passion and the sudden changes from joy to grief, from melancholy to exultation. (...) Instruments had to undergo a severe process of selection. Only those could be kept which had a sufficiently wide range and enough flexibity to afford all dynamic shades from pianissimo to fortissimo; instruments were expected to sing like human beings."

117 "A general account of the musical instruments used today, with their names and classification."
} 
instrumentos de uma mesma família, tão comuns durante o Renascimento. A esse respeito, comenta o autor (1986 [1619], p.47, tradução nossa):

Devemos, nesse momento, observar que de outrora aos nossos dias a maioria dos instrumentos de sopro - flautas doces, bombardas, charamelas, cromornes, entre outros - têm sido feitos em consorts com os tamanhos afinados na distância de uma quinta. É possível então sempre utilizar-se três tamanhos juntos (...), um primeiro para o baixo, um segundo para as partes de tenor e alto (uma vez que essas partes podem sempre ser tocadas por um mesmo tamanho de instrumento), e uma terceira para a parte do cantus. ${ }^{118}$

Ainda em relação aos instrumentos de sopro, Praetorius descreve nada menos do que quinze diferentes tipos principais (muitos deles construídos em diversos tamanhos), dentre os quais a grande maioria faz parte da família das madeiras, como se vê nas figuras a seguir, retiradas da citada Sciagraphia:

118 "We should at this point notice that from former times right up to our own day most wind instruments - recorders, bombards, schameis, crumhorns, and so on - have been made in consorts with the sizes pitched a 5th apart. It is thus possible always to use three sizes together (...), one size for the bass, a second for tenor or alto (since these parts can always be played by the same size of instrument), and a third one for the cantus parts." 


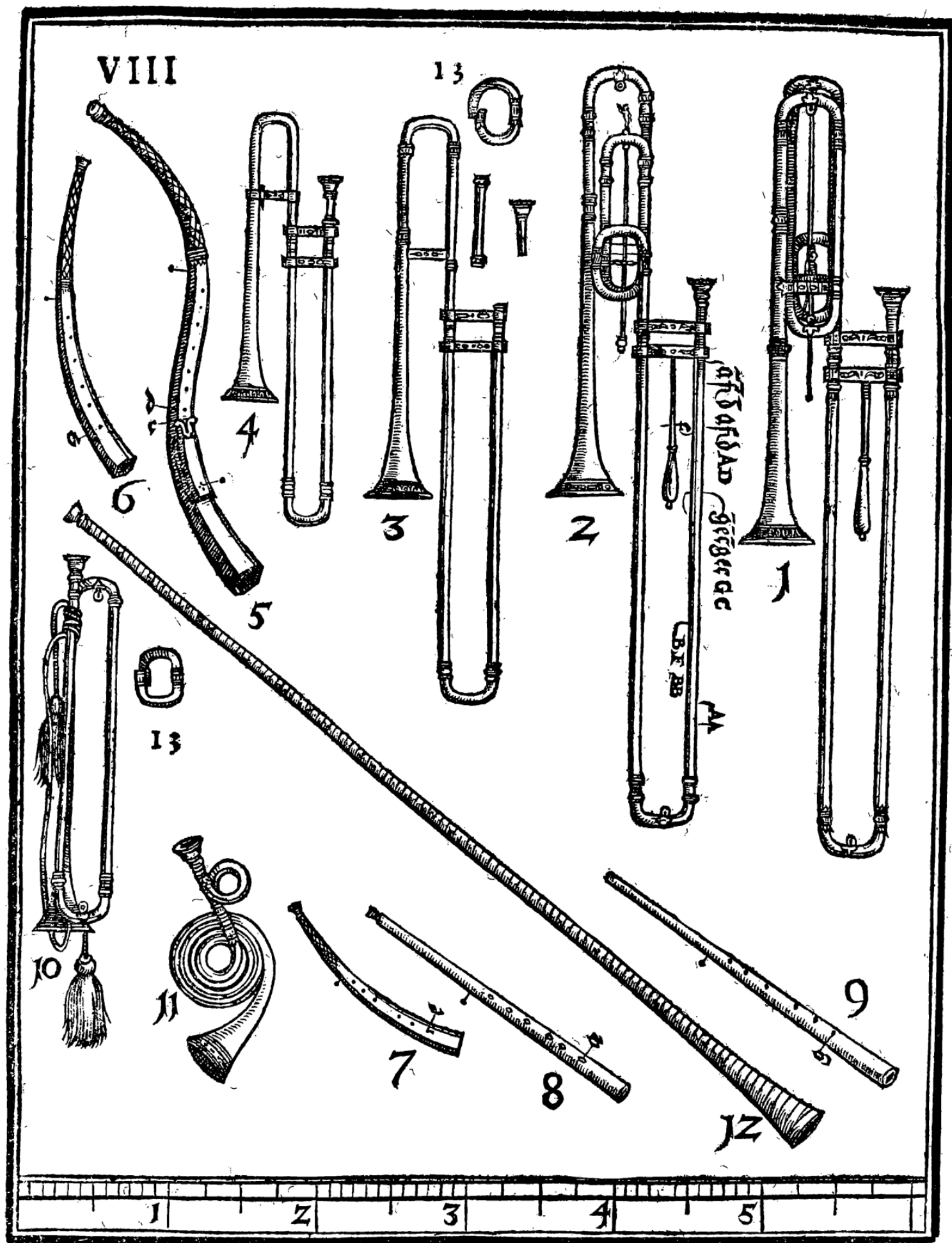

1. 2. Quart-\$pojaunen. 3. SRechte gemetne gfotaun. 4. Alt-Po/aun. 5. Corno

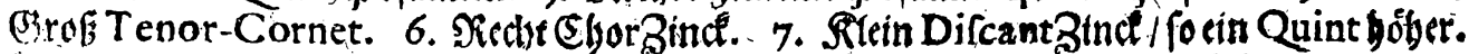

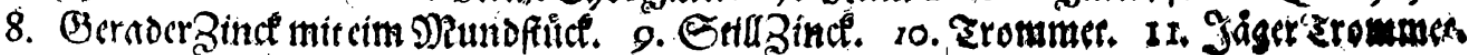

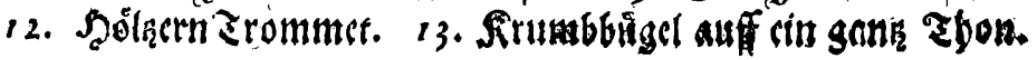

Fig. 27 - Gravura no. 8 da Sciagraphia, mostrando sacabuxas, cornetos e trompetes (PRAETORIUS, 1620) 


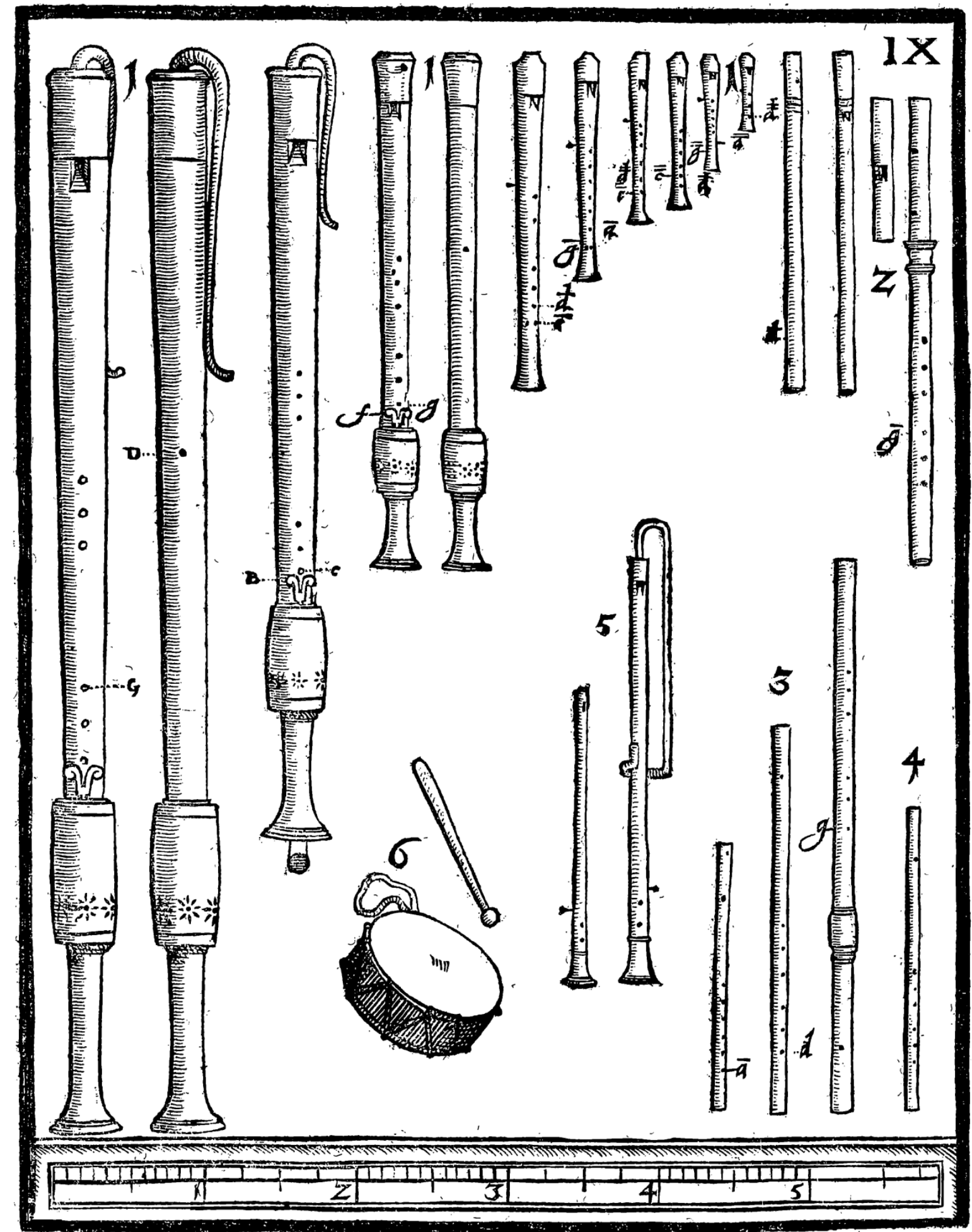

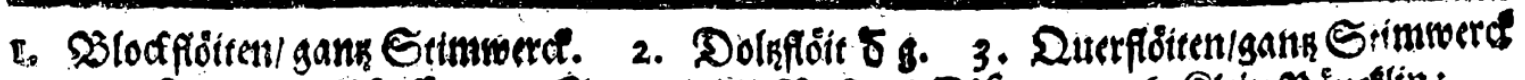

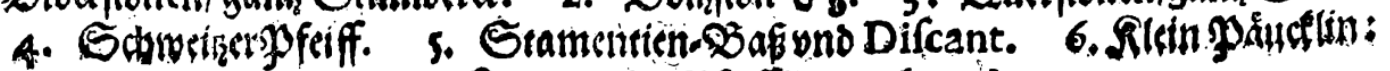
in oen Stamentien Pforffin uugstrauchen.

$$
\mathfrak{S} \quad \mathfrak{3}
$$

Fig. 28 - Gravura no. 9 da Sciagraphia, mostrando flautas doces, dolzflöts, flautas transversais, pífaro suíço, flauta tamborileira e tambor [pipe and tabor] (PRAETORIUS, 1620) 


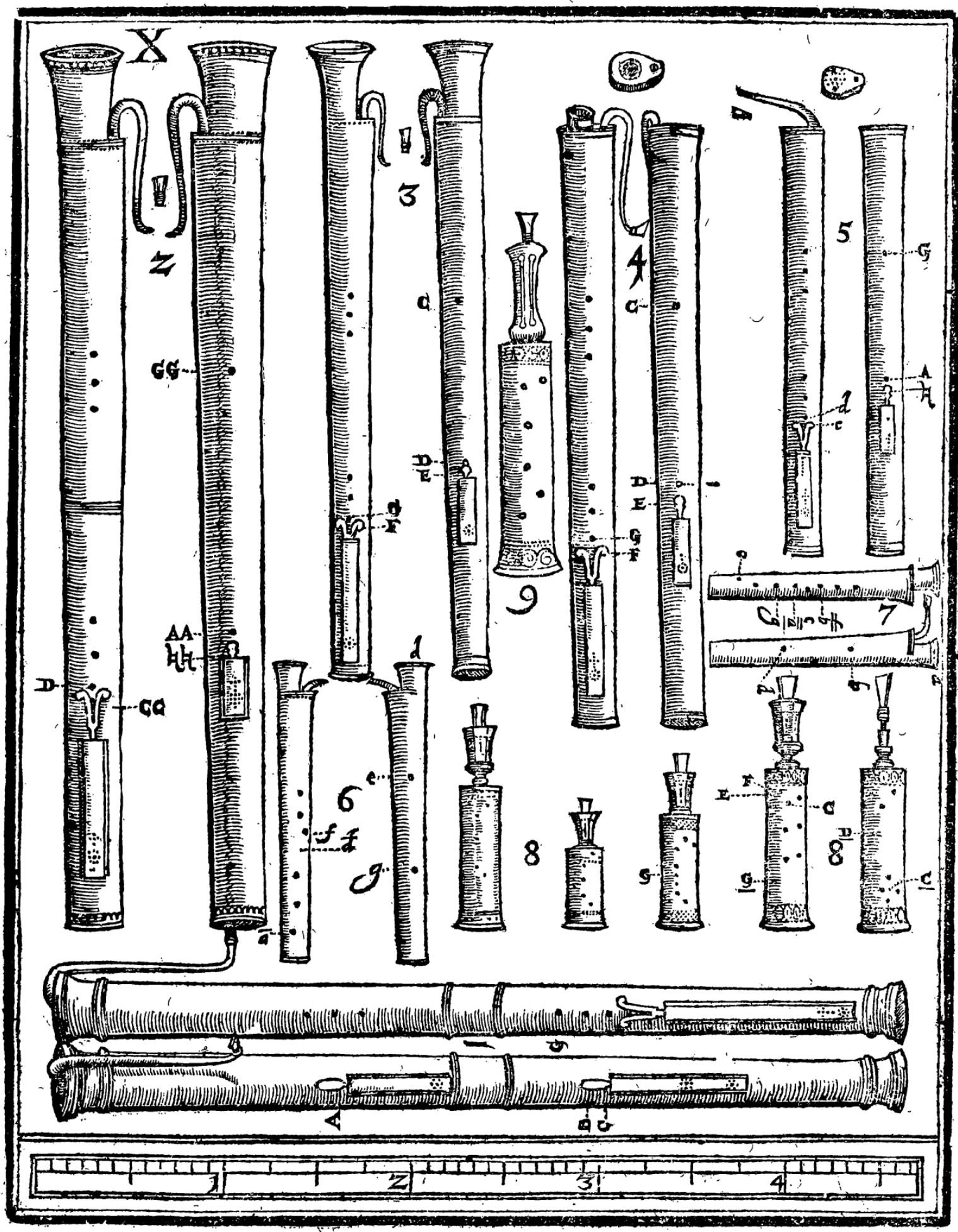

3. Sorducn-Bas auff bepben Esittetr. GG. 2o. Doppet-Fagott bis ins GG, 3. Offer Cho ${ }^{-}$

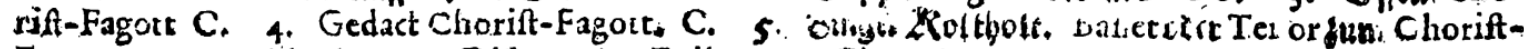
Fafolt. 6, 6. Alt. D. 7. Difcant Daer Exilent zum Chorः Fagott. a." 8. Ëtimwerdt Fianetten.

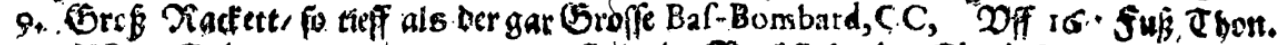

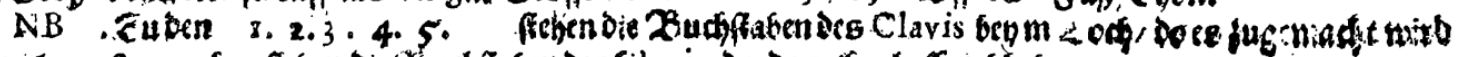

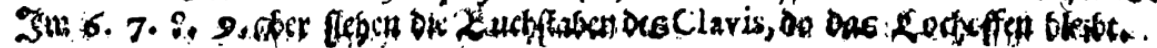




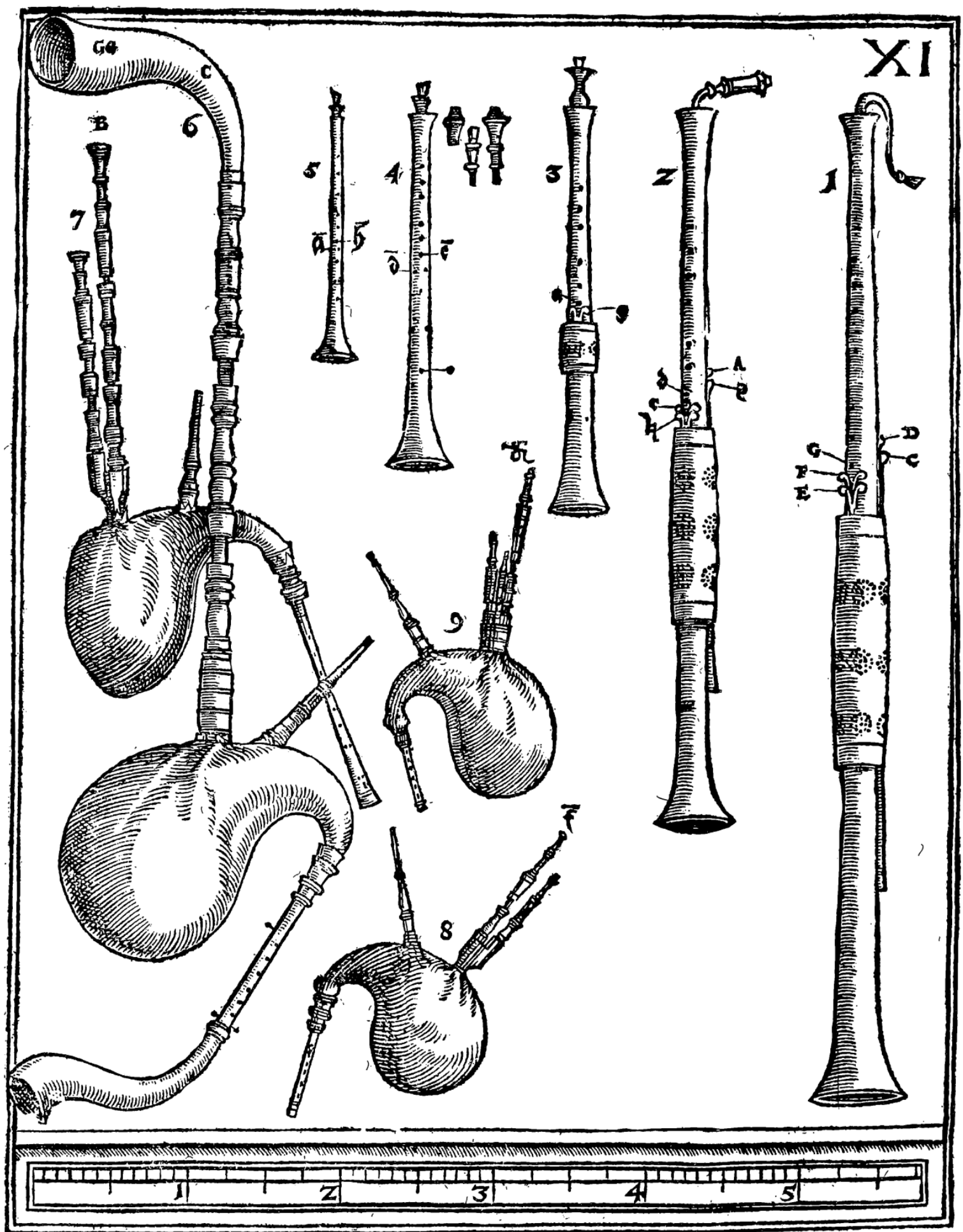

1. Bas'Pommer 2, Baflet oder Tenor-Pommer.' 3. Aitpomner.

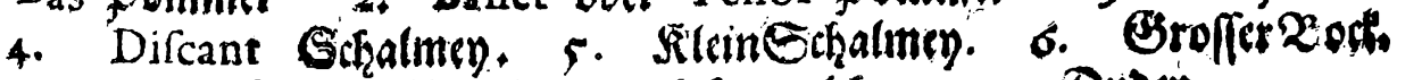
7. EchaperPfeifi. 8. Satmmelihen. 9. Dubey. 


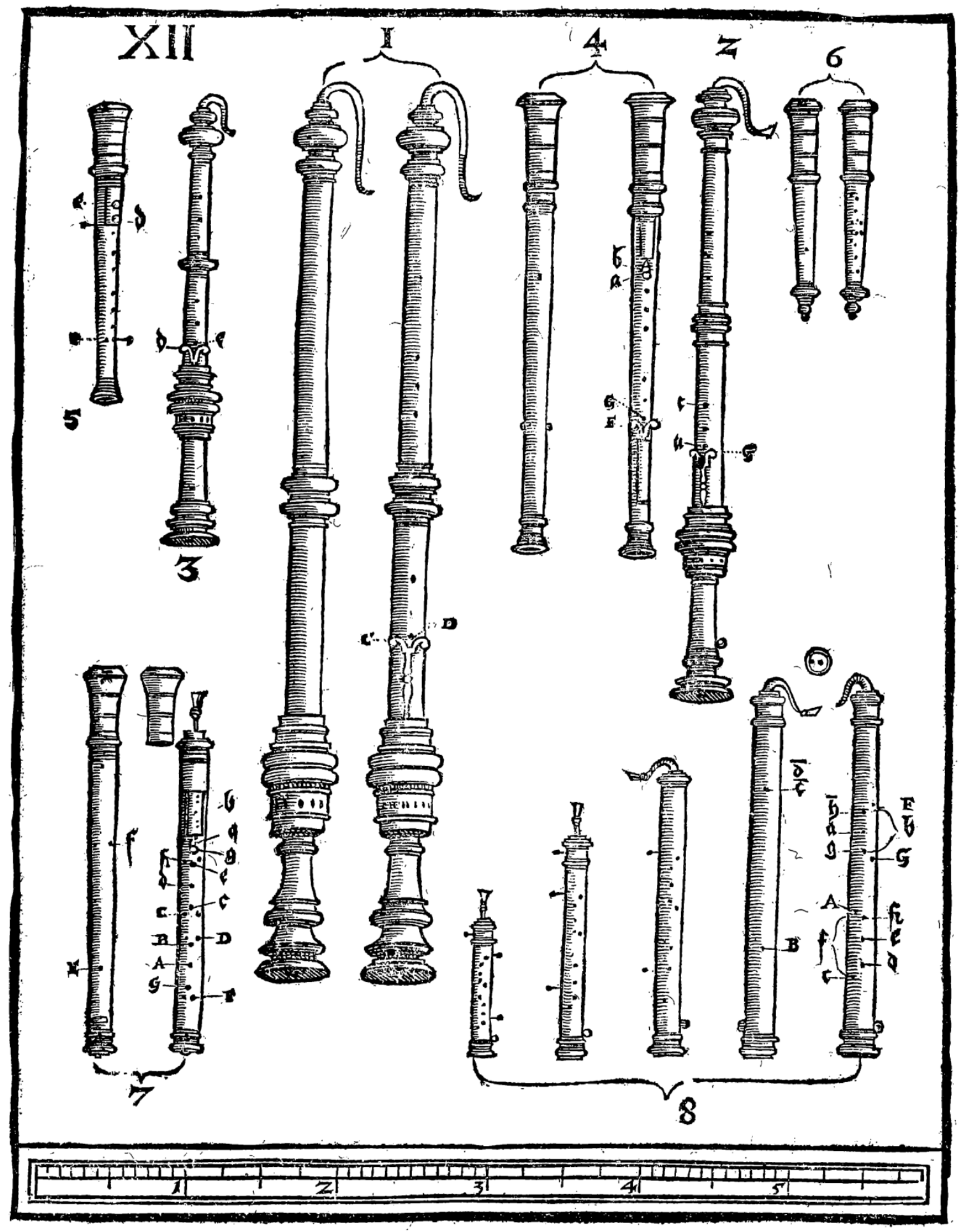

1. STaf yom Baffanelli. 2. Terior uno Alt Bafanclli, 3. Difcant Baffanelli. 4: Bais vom Schryari. 5. Tenor, Alt Schryari, 6. Cant Schryari. 7. Sf rrojokt

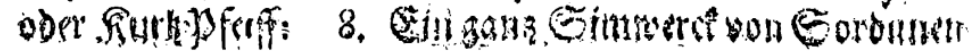

Fig. 31 - Gravura no. 12 da Sciagraphia, mostrando bassanelli, schryari, kortholt e sordun (PRAETORIUS, 1620) 


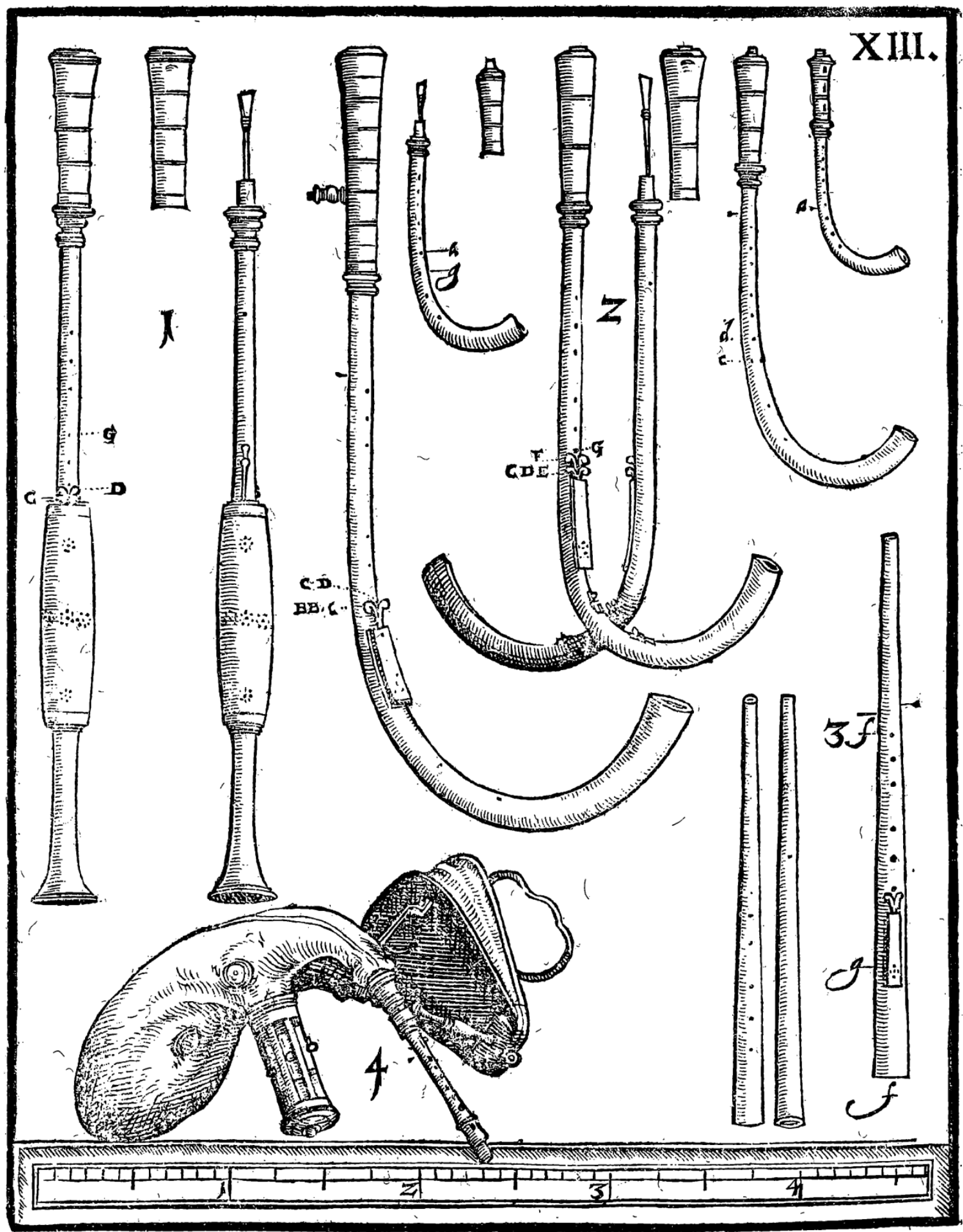

3. Baffett: Nicolo. 2, Rrumbfidner. 3, Cornetti mutiffulle Zindlen.

Fig. 32 - Gravura no. 13 da Sciagraphia, mostrando bassett, cromornes, cornetos mutti [mudos] e gaita-de-fole (PRAETORIUS, 1620) 
É curioso o fato de que tamanha quantidade de instrumentos ainda em uso no início do século XVII, como atestado por Praetorius, tenha sido abandonada ao longo do período. Não obstante, esse fato é explicado pela compreensão de que grande parte desses instrumentos, ou ainda de suas famílias, cumpriam funções específicas em meio à música renascentista, servindo bem para as tais; no entanto, as exigências expressivas do novo estilo que cada vez mais suplantava o antigo com o passar do século consideraram-nos insatisfatórios para a nova música, como explica Sachs:

\begin{abstract}
O primeiro sintoma [da seleção dos instrumentos] foi a rejeição da maioria daqueles do tipo do oboé, dos quais a palheta, sendo ela encoberta por um bocal, não podia ser controlada pelos lábios do intérprete. Como eles não tinham "expressão", elasticidade dinâmica e não eram capazes de produzir uma segunda oitava mais aguda por meio do sopro, eles não eram apropriados ao novo estilo. De forma repentina, rankets, cromornes, schryari, rauschpfeifen e gaitas-de-fole foram deixados de lado. Apenas os fagotes e, especialmente na França, as charamelas menores ou oboés foram preservadas, e com elas as flautas. (SACHS, 1940, p. 352, tradução nossa) ${ }^{119}$
\end{abstract}

Como se percebe, aqui o autor foca-se nos sopros de madeira por ser essa a família de instrumentos que mais teve membros caindo em desuso durante o período (os sopros de metal mencionados por Praetorius continuaram, em sua maioria, a ser usados ao longo do século XVII e XVIII). Curiosamente, o final da afirmação de Sachs pode parecer demasiadamente generalista, pois sabe-se que entre os citados instrumentos de madeira "sobreviventes" à seleção encontravam-se outros que continuaram a ser utilizados ao longo do século XVII e parte do XVIII, como o corneto e alguns tipos de gaita-de-foles (como a musette francesa). De qualquer modo, a informação do autor não é errônea, pois é notável que o fagote, o oboé e as flautas doce e transversal tornaram-se os sopros de madeira mais utilizados pelos compositores deste período, e serão esses os instrumentos (com exceção da flauta doce e somados à mais tardia clarineta) que chegarão a fazer parte da orquestra clássica do final do século XVIII. Os mencionados corneto e musette, por exemplo, não

\footnotetext{
119 "The first symptom was the dismissal of the majority of those oboelike instruments, the reed of which, being concealed within a Wind cap, could not be grasped by the player's lips. As they had no 'expression', no dynamic elasticity, and were not able to 'overblown' into a higher octave, they were not appropriate to the new style. All at once rankets, cromornes, schryari, rauschpfeifen, bagpipes were put aside. Only bassoons and, specially in France, the smaller schawms or oboes were preserved, and with them the flutes."
} 
sobreviveram às mudanças de estilo e gosto musical da época, e também caíram em desuso.

No século XVII parece haver a tendência à diminuição do uso de famílias completas de um mesmo instrumento de sopro. Cada vez mais fica clara a preferência pelo uso de poucos, ou mesmo de apenas um membro de cada grupo. Ainda que alguns dos instrumentos que podemos aqui chamar de "sopros de madeira principais" (o foco desta pesquisa) tenham continuado a ser construídos em consorts e com eles utilizados durante boa parte do século XVII (notavelmente na França, onde famílias de oboés e flautas doces ainda fizeram parte dos conjuntos instrumentais até fins do período), aos poucos esse uso tornou-se obsoleto. Spitzer e Zaslaw (2004, p. 310, tradução nossa) explicam o fato dando como exemplo os oboés:

\begin{abstract}
Oboés alto e tenor, que algumas vezes tocavam as partes intermediárias na orquestra de Lully, foram parcamente utilizados na Itália e na Inglaterra. $\mathrm{Na}$ Alemanha, o oboé d'amore, em lá, e o oboé da caccia, em fá, desfrutaram de certa popularidade como solistas obbligati no início do século XVIII, mas estavam fora de moda por volta de 1740. Já no começo do século XVIII a instrumentação mais comum na França bem como no restante da Europa era um par de oboés soprano, que podiam tanto tocar partes solistas quanto dobrar as partes de violino. ${ }^{120}$
\end{abstract}

De fato, no século XVIII ainda era possível encontrar-se diferentes tipos de instrumentos familiares às flautas doce e transversal, ao oboé, ao fagote e também à clarineta, mas nenhum deles jamais foi usado com frequência igual à dos principais, sendo requisitados pelos compositores esporadicamente. Alguns desses instrumentos (como o piccolo, o corne-inglês e o contra-fagote), continuaram a ser utilizados na orquestra clássica e nas posteriores, mas com participação circunstancial, enquanto outros foram esquecidos.

É preciso lembrar que do Barroco ao Romantismo os instrumentos musicais, principalmente os sopros, passaram por mudanças em sua construção, a fim de que

\footnotetext{
120 "Alto and tenor oboes, which sometimes played the middle parts in Lullys's orchestra, were sparingly used in Italy and England. In Germany the hautbois d'amour, pitched in A, and the oboe da caccia, pitched in $F$, enjoyed a vogue as obbligato soloists in the early eighteenth century, but had passed out of fashion by 1740. Already at the beggining of the the eighteenth century the most common scoring in France as well as the rest of Europe was a pair of treble oboes, who could either play solo parts or double the violin parts."
} 
pudessem melhor se adaptar ao estilo musical de cada período. À adaptação somavam-se novas possibilidades técnicas e de sonoridade, o que fez com que os instrumentos do final do século XVIII, por exemplo, fossem consideravelmente diferentes dos seus antecedentes seiscentistas. Do século XVII ao XIX não é possível falar-se em uma padronização dos tipos de instrumentos usados, uma vez que ela começou a ocorrer apenas após 1850, quando os instrumentos que hoje chamamos de "modernos" surgiram no meio musical. Spitzer e Zaslaw comentam: "Muitos tipos diferentes de instrumentos de sopro foram usados em conjuntos instrumentais entre 1600 e 1800, e muitas formas diferentes do mesmo instrumento." (2004, p. 24, tradução nossa) ${ }^{121}$. Mesmo assim, percebe-se que há um tempo até que todos eles sejam aceitos e igualmente utilizados. Durante praticamente três séculos diversos tipos de um mesmo instrumento conviveram num meio onde as luterias produziam novidades com notável frequência.

As madeiras que adentram o século XVIII, ou seja, as barrocas, são "invenções" do século XVII. Com exceção da clarineta, que muito provavelmente tem suas origens na Alemanha do final do período (ou início do próximo), os outros instrumentos principais são certamente inventos franceses, surgidos a partir da transformação de instrumentos renascentistas. Das antigas charamelas mais agudas deriva o oboé; das dulcianas, o fagote; da flauta transversal tenor, o traverso; e das diferentes flautas doces, seus correspondentes barrocos.

Ainda hoje é difícil saber com exatidão quais modelos dos instrumentos teriam surgido e sido utilizados em quais datas, mas no início do XVIII já é possível se ter uma melhor ideia do que seriam, de fato, as madeiras barrocas.

O surgimento desses instrumentos deu-se certamente devido à busca de um refinamento de seus correspondentes da Renascença. Como se vê, a nova música não só gerou a seleção de instrumentos, como também exigiu dos escolhidos uma melhoria de suas capacidades musicais, como explicam Spitzer e Zaslaw (2004, p. 94, tradução nossa): “Flautas doces, flautas transversais, oboés e fagotes 'barrocos'

\footnotetext{
121 "Many different types of wind instruments were used in instrumental ensembles between 1600 and 1800 , and many different forms of the same instruments."
} 
resultaram de décadas de modificações dos instrumentos e da forma como eram tocados por muitos instrumentistas" ${ }^{122}$

Bruce Haynes (2001, p. 56-57, tradução nossa) descreve de forma muito interessante um período no qual as mudanças dos instrumentos interferiram em seu uso nos grupos instrumentais. Ainda que tratando especificamente do oboé, o autor elucida situações que podem ter sido comuns também para as outras madeiras:

\begin{abstract}
O ano de 1664 é notável por duas (outras) razões. Depois da produção de Les plaisirs de l'isle enchantée em maio, Lully parece ter parado de usar hautboys em suas produções dramáticas por diversos anos. Entre 1664 e 1670 ele produziu quatorze ballets e comédie-ballets em larga-escala. Algumas dessas produções usavam 'flautas', mas nenhuma parece ter envolvido o oboé. Não se ouve de fato a respeito do instrumento novamente até a produção de Le Bourgeois Gentilhomme (1670). O estado fragmentado das fontes sobreviventes a respeito de Lully torna difícil desenhar conclusões definitivas com apenas essa base, mas a menção regular do 'hautbois' novamente depois de 1670 (agora em quatro ao invés de cinco partes) sugere que $o$ instrumento teria sido propositalmente omitido das performances na corte por esses seis anos.

Se um novo modelo, o hautboys definitivo (...), tinha aparecido por volta de 1664 e os intérpretes estavam aprendendo a usá-lo, ou se ele estava sendo desenvolvido nos anos seguintes à execução de Les Plaisirs de l'isle enchantée, Lully parece deliberadamente ter permitido aos instrumentistas de sopro um período de tolerância, no qual foi a eles dada a chance de trabalhar no design do novo instrumento bem como na técnica de tocá-lo. ${ }^{123}$
\end{abstract}

Do trabalho de luthiers ao longo do século XVII resultou o surgimento de instrumentos considerados mais refinados que os antigos, mais adequados à execução da música então em voga. Foi o refinamento das madeiras que Ihes possibilitou a participação nos grupos instrumentais dominados pelas cordas. Era o início de seu uso orquestral:

\footnotetext{
122 "'Baroque' recorders, flutes, oboes, and bassoons resulted from decades of changes in the instruments and the way they were played by many instrumentalists."

123 "The year of 1664 is remarkable for two other reasons. After the production of Les plaisirs de l'isle enchantée in May, Lully seems to have stopped using hautboys in this dramatic productions for several years. Between 1664 and 1670 he produced fourteen large-scale ballets and comédie-ballets. Some of these productions called for 'flûtes', but none seems to have involved the hautboy. We do not in fact hear of the instrument again until the production of Le Bourgeois Gentilhomme (1670). The fragmentary state of surviving Lully sources makes it difficult to draw definite conclusions on this basis alone, but the regular mention of 'hautbois' again after 1670 (now in four rather than five parts) suggests that the instrument had been purposely omitted from the court performances for these six years. Whether a new model, the definite hautboy (...), had appeared by 1664 and players were learning to use it, or whether it was being developed in the years following the performance of Les Plaisirs de l'isle enchantée, Lully seems deliberately to have allowed his wind players a grace period, in which they were given a chance to work on the design of the new instrument and the technique of playing it."
} 
[No século XVI e início do XVII] os sopros normalmente formavam grupos separados, que tocavam sozinhos, frequentemente no palco e usando figurinos, como no Ballet des muses. Eles raramente tocavam ao mesmo tempo com as cordas ou os instrumentos do continuo. A reformulação dos instrumentos de sopro realizada por músicos e artesãos franceses na segunda metade do século XVII facilitou com que tocassem juntamente ao conjunto de instrumentos da família do violino, e os instrumentistas de sopro começaram a se sentar na "orquestra" com as cordas, onde frequentemente dobravam as partes de cordas e algumas vezes tocavam uma linha em obbligato. (SPITZER e ZASLAW, 2004, p. 24, tradução nossa) ${ }^{124}$

\section{A figura do mencionado Jean-Baptiste Lully (1632-1687) é normalmente vista} como pioneira na junção dos instrumentos de sopro barrocos aos de corda, dando assim início ao grupo que poderemos mais tarde chamar efetivamente de "orquestra". Spitzer e Zaslaw explicam detalhadamente o uso dos sopros na orquestra pelo compositor:

A Lully é frequentemente dado o crédito pela introdução das novas madeiras "barrocas" na orquestra (...). Lully de fato tem o mérito de integrar os instrumentos de sopro à orquestra de cordas. Antes de assumir o controle do estabelecimento musical real, os sopros quase sempre tocavam como um grupo distinto e autossuficiente - no jantar do rei, em eventos ao ar livre, ou nos ballets de cour. Lully, também, começou a usar os sopros como um grupo separado, por exemplo, no Ballet de l'amour malade (1657), no qual o noivo em um casamento camponês na última entrée dança ao som de uma 'banda campestre [concert champêtre]' de hautbois. Logo, entretanto, ele começa a encontrar novos modos de combinar sopros e cordas. Na symphonie do início de Les Amours déguisés (1664) conjuntos de cordas e sopros envolvem-se de forma mais próxima: um grupo de flautas a quatro partes acompanhando as "Graças e Prazeres" alterna com um conjunto de cordas a cinco partes que acompanha as "Artes e Virtudes". Em Alceste (1674) oboés e cordas são combinados em um só grupo e tocam em uníssono, os oboés marcados fort, os violinos doux. No "Sommeil" de Atys (1676) Lully alterna e combina flautas doces e violinos: por vezes um trio de flautas, por outras violinos a cinco partes, algumas vezes flautas e violinos juntos. Em Persée (1682) ele escreve muitas partes na passacaille para oboés, flautas e violinos, todos tocando ao mesmo tempo.

Instrumentações como essas eram novas e de certo modo experimentais. Entre 1672 e 1687 Lully tinha a orquestra da Opéra à sua disposição, os mesmos instrumentos e os mesmos músicos, de cordas e sopros, ano após ano. A disponibilidade e estabilidade de instrumentos e pessoal permitiu a ele tentar novas combinações, novas texturas, e novos efeitos. Ele experimentou com combinações de cordas e sopros como as descritas

124 "The winds usually formed separate ensembles, which played by themselves, often onstage and in costume, as in the Ballet des muses. They rarely played at the same time as the strings or the continuo instruments. The redesign of wind instruments undertaken by French musicians and craftsmen in the second half of the seventeeth century made it easier for them to play along with an ensemble of violinfamily instruments, and wind players began to sit in the 'orchestra' with the strings, where they often doubled the string parts and sometimes played an obbligato line." 
acima. Experimentou com cordas reduzidas, especialmente com texturas de trio, mas também com algumas texturas a quatro partes e outras nas quais as violas se encarregavam linha do baixo. Também experimentou com combinações de instrumentos e vozes, nas quais a orquestra continuava a tocar enquanto um solista cantava recitativos e árias. Ocasionalmente, ele permitia que cordas a cinco partes acompanhassem uma voz solo. Mas mais frequentemente ele diminuía o volume da orquestra nesse tipo de passagens reduzindo a textura para um trio de cordas, às vezes tocado por membros do petit choeur, às vezes por todos os violinos e baixos. Ele chegou até a experimentar com passagens nas quais sopros faziam 0 acompanhamento vocal, como por exemplo o par de flautas que acompanha o final da cena de "Sommeil" de Atys (1676), ou um trio de oboés que toca enquanto Proteus canta em Phaëton (1683). Para Lully, a orquestra da Opéra deve ter sido algo como um laboratório, no qual podia tentar combinações orquestrais cada vez mais aventurosas. E ele pode não ter sido o único a experimentar: talvez os músicos da orquestra da Opéra tentassem novas combinações e novos sons e trouxessem suas melhores descobertas para que Lully as incorporasse a suas obras. (SPITZER e ZASLAW, 2004, p. 93, 95, 96, tradução nossa) ${ }^{125}$

125 "Lully is often given credit for introducing new 'Baroque' woodwind instruments into the orchestra. (...) Lully does deserve credit in any case for integrating the wind instruments into the string orchestra. Before he assumed control of the royal musical establishment, the winds almost always performed as a distinct and self-contained band - at the King's supper, at outdoor events, or in the ballets de cour. Lully, too, began by using the winds as a separate band, for example in the Ballet de l'amour malade (1657), where the groom at a peasant wedding in the last entrée dances to the sound of a 'country band [concert champêtre]' of hautbois. Soon, however, he began to find new ways to combine winds and strings. In the symphonie at the beggining of Les amours déguises (1664) wind and string bands engage at closer quarters: a four-part flute ensemble accompanying the 'Graces and Pleasures' alternates with a five-part string band that accompanies the 'Arts and Virtues'. In Alceste (1674) oboes and strings are combined into a single band and play in unison, the oboes marked fort, the violins doux. In the 'Sommeil' of Atys (1676) Lully alternates and combines recorders and violins: sometimes a recorder trio, sometimes five-part violins, sometimes recorders and violins together. In Persée (1682) he writes several passages in the passacaille for oboes, flutes, and violins, all playing at the same time.

Scorings like these were new and in a sense experimental. Between 1672 to 1687 Lully had the orchestra of the Opéra at his disposal, the same instruments and the same players, both strings and winds, year after year. The avaliability and stability of instruments and personnel allowed him to try new combinations, new textures, and new affects. He experimented with combinations of strings and winds as described above. He experimented with reduced strings, especially trio textures, but also some fourpart textures and textures in which the violas take over the bass line. He also experimented with combinations of instruments and voices, in which the orchestra continued to play while a soloist sang recitatives and airs. Ocasionally he allowed five-part strings to accompany a solo voice. But more often he lowered the volume of the orchestra in such passages by reducing the texture to a string trio, played sometimes by the members of the petit choeur, sometimes by all the violins and basses. He even experimented with passages in which winds provided vocal accompaniment, for example the pair of flutes that accompany the end of the 'Sommeil' scene in Atys (1676), or the trio of oboes that plays as Proteus sings in Phaëton (1683). For Lully the orchestra of the Opéra must have been something like a laboratory, in which he could try out increasingly adventurous orchestral combinations. And he may not have been the only experimenter: perhaps the players in the Opéra orchestra tried out new combinations and new sounds and brought their best discoveries to Lully for him to incorporate in his works." 
De forma perspicaz, os autores afirmam que "se Lully não foi o pai biológico da orquestra, foi ao menos o seu padrinho." (2004, p.72, tradução nossa) ${ }^{126}$.

Vê-se que, assim como em diversos outros momentos na história da orquestração, as inovações se deram graças à disponibilidade de um grupo com o qual o compositor poderia experimentar. Isso, é claro, não diminui a engenhosidade do artista que opera tais inovações.

A variedade de sonoridades obtidas nas orquestrações de Lully é notável e é possível imaginar que grande parte delas tenha sido utilizada também por outros compositores. No entanto, é importante novamente reforçar que algumas dessas cores orquestrais, principalmente aquelas formadas por famílias de um mesmo tipo de instrumento de madeira (como as das flautas doces e oboés) cairia em desuso no século XVIII:

(...) na orquestra de Lully, onde os instrumentos de sopro foram primeiramente combinados com as cordas de modo orquestral, os primeiros tinham sido organizados em quatro partes - dessus de hautbois, hautecontre de hautbois, taille de hautbois e basse de hautbois. Mas Lully, em suas obras mais tardias, preferia escrever para os sopros em trio ao invés da textura em quatro partes, e as orquestras francesas tinham abandonado as partes intermediárias dos sopros por volta da segunda década do século XVIII. A maioria das orquestras de outros países nunca os haviam utilizado. (SPITZER e ZASLAW, 2004, p. 315, tradução nossa) ${ }^{127}$

Os autores buscam explicar esse fato, comparando as formações orquestrais do século XVII com aquela dita "clássica", de fins do século XVIII:

\begin{abstract}
Por que os sopros abandonam a instrumentação a quatro partes no século XVIII, uma vez que as cordas adotavam-na? Uma explicação possível é a de que os sopros, de forma distinta das cordas orquestrais, vinham de muitas famílias diferentes de instrumentos. Era economicamente impraticável contratar instrumentistas de sopro o bastante para constituir coros de flautas, clarinetas ou trompas a quatro partes. Pares de flautas, oboés, trompas e fagotes poderiam funcionar como um só coro de sopros misto, oferecendo um ao outro suporte timbrístico adequado a relativamente baixo custo. Dessa forma, durante a primeira metade do século XVIII os indiferenciados "oboés" das formações orquestrais mais antigas foram
\end{abstract}

126 "If Lully was not the orchestra's biological father, he was at least its godfather."

127 “(...) in Lully's orchestra, where wind instruments were first combined with strings in orchestral fashion, the winds had been scored in four parts - dessus de hautbois, haute-contre de hautbois, taille de hautbois, and basse de hautbois. But Lully in his later works preferred to write for winds in trio rather than four-part texture, and French orchestras had abandoned the middle wind parts by the second decade of the eighteeth century. For the most part orchestras in other countries had never used them." 
substituídos por pares de especialistas nos vários instrumentos de sopro. (SPITZER e ZASLAW, 2004, p.315-316, tradução nossa) $)^{128}$

No que diz respeito ao uso dos instrumentos como alegorias no século XVII, os tratados e outros documentos textuais seiscentistas parecem ter legado pouca informação. Dois dos mais importantes documentos focados em instrumentos musicais, a já mencionada segunda parte do Syntagma Musicum de Praetorius e também o livro sobre instrumentos pertencente à Harmonie Universelle de Marin Mersenne (1636), considerados essenciais para a organologia, são fonte riquíssima de informações detalhadas sobre a construção e funcionamento dos instrumentos musicais do período, mas não abordam com mais profundidade muitos outros aspectos relacionados a eles. De qualquer modo, é evidente que os instrumentos musicais foram, sim, utilizados na música da época a partir de seus potenciais alegóricos e isso fica claro a partir do repertório. Encontra-se, por exemplo, nas figuras dos mencionados Monteverdi e Lully dois importantes compositores que se utilizaram dos instrumentos através desse viés, não sendo eles, entretanto, os únicos a fazê-lo. 0 século XVIII, por sua vez, parece continuar a tradição alegórica dos instrumentos de forma semelhante ao período anterior. Sendo assim, falar-se-á também de exemplos musicais do século XVII quando cada um dos instrumentos de madeira for abordado individualmente.

\footnotetext{
128 "Why did winds abandon four-part scoring in the eighteenth century, just as stringed instruments were adopting it? One possible explanation is that the winds, unlike orchestral strings, came from several different families of instruments. It was economically impractical to hire enough wind players to constitute four-part flute, clarinet, or horn choirs. Pairs of flutes, oboes, horns, and/or bassoons could function as a single mixed wind choir, offering one another adequate timbral support at relatively low cost. Thus, during the first half of the eighteeth century the undifferentiated 'oboes' on earlier orchestra rosters were replaced by pairs of specialists on the various wind instruments."
} 


\section{OS INSTRUMENTOS DE SOPRO DE MADEIRA NO SÉCULO XVIII: CARACTERÍSTICAS, SIGNIFICADOS E USO ALEGÓRICO}

\subsection{O Musikalisches Theatrum de Weigel}

Dentre os documentos iconográficos ${ }^{129}$ que destacam os instrumentos musicais publicados no século XVIII, o Musikalisches Theatrum de Johann Christoph Weigel é aqui de especial interesse, uma vez que a partir de seu conteúdo pode-se constatar diferentes aspectos a respeito das condições sociais e também do olhar sobre o caráter e algumas das possibilidades alegóricas dos instrumentos no início do período.

Weigel (1661-1726) foi um gravador, editor e negociante de arte alemão estabelecido em Nuremberg e o Musikalisches Theatrum é talvez sua obra mais conhecida.

Provavelmente datada de cerca de 1722, a publicação é formada por trinta e seis ilustrações feitas em placas de cobre, divididas em dois volumes, nas quais são retratados músicos tocando diversos instrumentos. Em seu extenso e autoexplicativo título lê-se: "Teatro Musical, no qual todos os instrumentos pertencentes a essa nobre arte são vividamente mostrados em posturas graciosas e apresentados a todos os amantes da música para sua agradável diversão"130. As imagens são, portanto, concebidas como entretenimento visual. Todavia, apresentam muita informação a partir das escolhas do artista ao retratar diferentes vestimentas, ambientações e paisagens que se relacionam diretamente com as figuras dos intérpretes executando

\footnotetext{
${ }^{129} \mathrm{~A}$ representação iconográfica de instrumentos musicais em documentos diversos oriundos do século XVIII é bastante vasta. Em pinturas, desenhos, gravuras, esculturas, etc, é possível encontrar instrumentos (retratados com precisão organológica e realismo ou não) em cenas e paisagens míticas ou reais, em retratos, entre outros gêneros. No entanto, esse conteúdo iconográfico é de tal modo abundante que seu levantamento e análise aprofundada necessitaria de uma pesquisa própria e específica, na qual seu montante de informação poderia ser avaliado em detalhes. Além disso, são mais raros exemplos nos quais os instrumentos musicais são o foco principal da obra. Nessa pesquisa, escolheu-se buscar informações sobre as madeiras e seu potencial alegórico principalmente em documentação teórica escrita e prática-musical. Portanto, quando aqui mencionados, os documentos iconográficos assim o são por mostrarem-se como exemplos importantes das questões tratadas ou por estarem intimamente conectados a outros documentos específicos (como é o caso das ilustrações do Iconologia de Cesare Ripa).

130 "Musikalisches Theatrum, auf welchen alle zu dieser edlen Kunst geröhige Instrumenta in anmuthigen Posituren lebhafft gezeiget und allen Music Liebhabern zu gefälliger belustigung vorgestellet werden."
} 
seus instrumentos. Além disso, sob cada gravura está impresso um texto específico, cujos versos retratam características de cada instrumento musical de forma poética.

Ainda que as ilustrações não apresentem os instrumentos musicais com a mesma correção, precisão métrica e riqueza de detalhes da publicação de Praetorius, por exemplo, elas explicitam características relevantes. Como afirma E.H. (o nome abreviado provavelmente corresponde ao musicólogo Edgar Hunt) em sua crítica a uma edição da obra publicada em 1961,

Apesar desses excelentes desenhos serem, de certo modo, derivativos e conterem uma série de erros óbvios, eles são extremamente valiosos ao mostrar, inter alia, os instrumentos individuais da época de Bach em ação. (Music \& Letters, 1962, p. 74, tradução nossa) $)^{131}$

A pretensão em representar "todos os instrumentos" claramente não obtém êxito quando vista sob um olhar mais amplo. No entanto, fica claro que os ali retratados são os mais conhecidos e de algum modo utilizados no período. De fato, são os mais importantes instrumentos usados na música europeia no início do século XVIII.

Um dos primeiros aspectos a chamar atenção na obra é a sua divisão em dois volumes, nos quais o autor claramente faz uma distinção entre os instrumentos, separando-os em dois grupos: os utilizados para a música "nobre" da corte (no volume I), e os usados para a música militar e camponesa (volume II). Rice (1992, p.138, tradução nossa) explica essa divisão, atentando para a conexão de Weigel com uma obra de outro importante tratadista alemão do período:

De acordo com Berner (1961:p.viii), um capítulo intitulado 'Von den Musikaslichen Instrumente' no Das Neu-Eröffnete Orchestre de Johann Mattheson (1713), serviu de guia para o planejamento e execução da coleção de trinta e seis gravuras descrevendo músicos de Weigel. Mattheson avaliou vários instrumentos com base em seu apelo estético e mencionou seu uso por diferentes membros da sociedade. A coleção de Weigel reflete a visão de Mattheson ao contrastar uma elegante e cortesã

131 "Although these excellent drawings are to some extent derivative and contain a number of obvious mistakes, they are extremely valuable in showing, inter alia, the individual instruments of the Bach period in action." 
vida musical em sua primeira seção com uma forma de fazer-musical de camponeses e soldados numa segunda. De fato, dos vinte e três instrumentos musicais descritos por Mattheson, todos com exceção de um (o chalumeau) são mostrados por Weigel. ${ }^{132}$

Fica claro que a separação dos instrumentos nos dois volumes reflete condições sociais diferentes. Assim, os instrumentos do primeiro são aqueles que, à época, eram vistos como os mais indicados à música considerada de caráter mais elevado. Os intérpretes retratados nesse volume aparecem vestidos com roupas cortesãs e estão sempre localizados em ambientes palacianos ou outros frequentados pela nobreza. No segundo volume são representadas figuras de aldeões, pastores e soldados, trajando sua vestimenta característica, em meio a vilas, campos e acampamentos militares.

As gravuras representando a flauta doce, a flauta transversal, o oboé, a clarineta e o fagote estão presentes no primeiro volume, mostrando os mesmos como instrumentos de alta estirpe. Por um lado, esse fato poderia ter, por si só, caráter alegórico, uma vez que esses instrumentos seriam vistos como símbolos da música culta, enquanto que uma eventual aparição de qualquer instrumento retratado no segundo volume, se ocorrida em meio aos do primeiro, sugeriria uma ambientação além dos domínios da nobreza, ou ainda uma música mais popularesca, funcional ou de menor valor. Apesar disso, possíveis associações alegóricas às madeiras podem ser mais diretamente encontradas no conteúdo dos poemas que acompanham suas representações. Importante também é o fato de que as madeiras são mostradas em sua forma "barroca", ou seja, em seus modelos mais usuais no início do século XVIII, fruto das significativas transformações de sua construção nas décadas anteriores e que seriam o ponto de partida para outras mudanças estruturais pelas quais passariam durante os anos seguintes.

A seguir, as gravuras referentes a cada instrumento, bem como a tradução de cada um dos poemas.

\footnotetext{
132 “According to Berner (1961:p.viii), a chapter entitled 'Von den Musikaslichen Instrumente' in Johann Mattheson's Das Neu-Eröffnete Orchestre (1713) served as a guide for the planning and execution of Weigel's collection of thirty-six engravings depicting musicians. Mattheson evaluated several instruments on the basis of their aesthetic appeal and mentioned their use by different members of society. Weigel's collection reflects Mattheson's approach in that it contrasts a courtly, elegante musical life in its first section with a peasant's or soldier's form of music-making in its second. Indeed, of twentythree musical instruments described by Mattheson, all but one (the chalumeau) are shown by Weigel."
} 


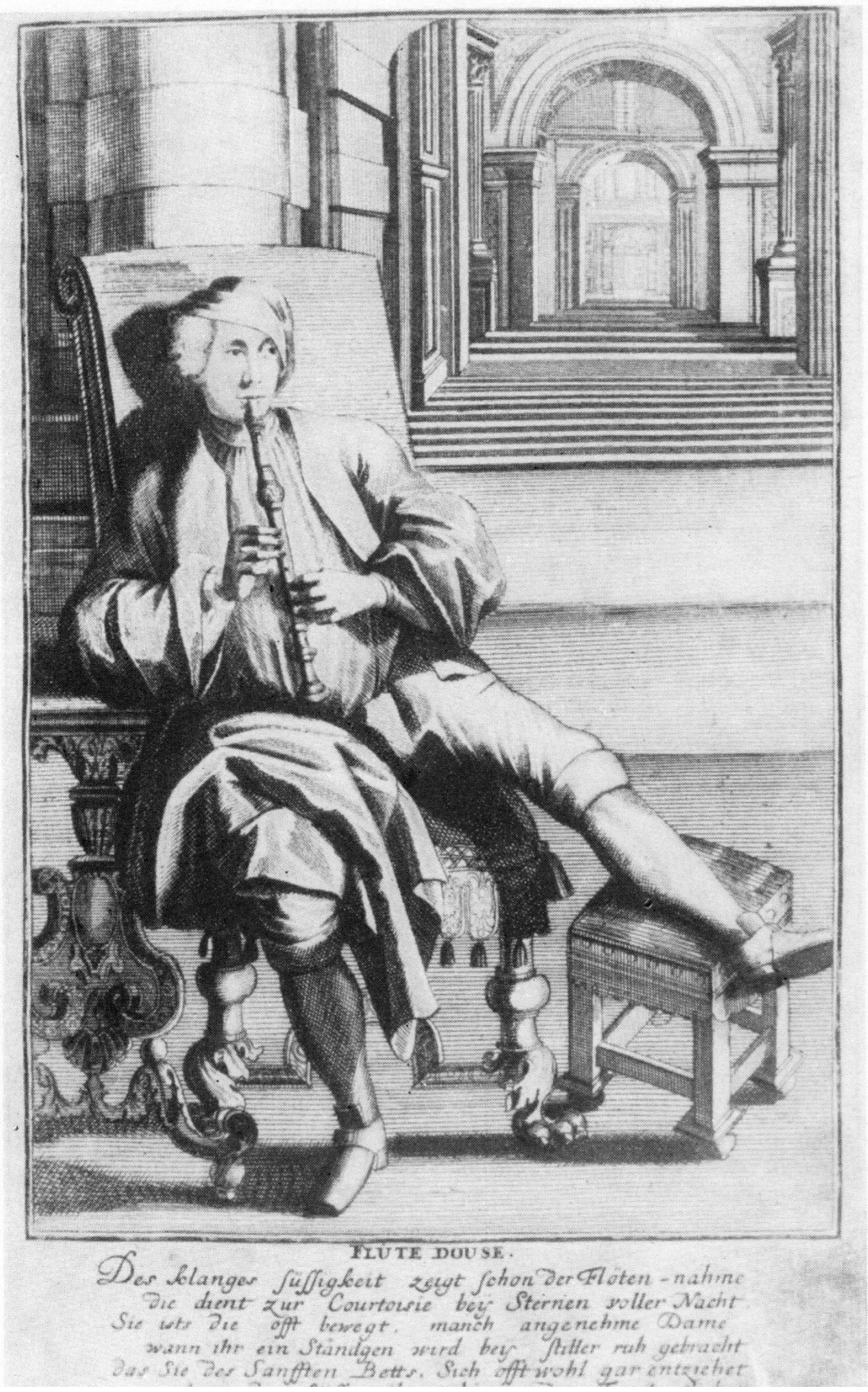

Fig. 33 - Gravura mostrando a Flauta Doce (WEIGEL, ca.1722) 


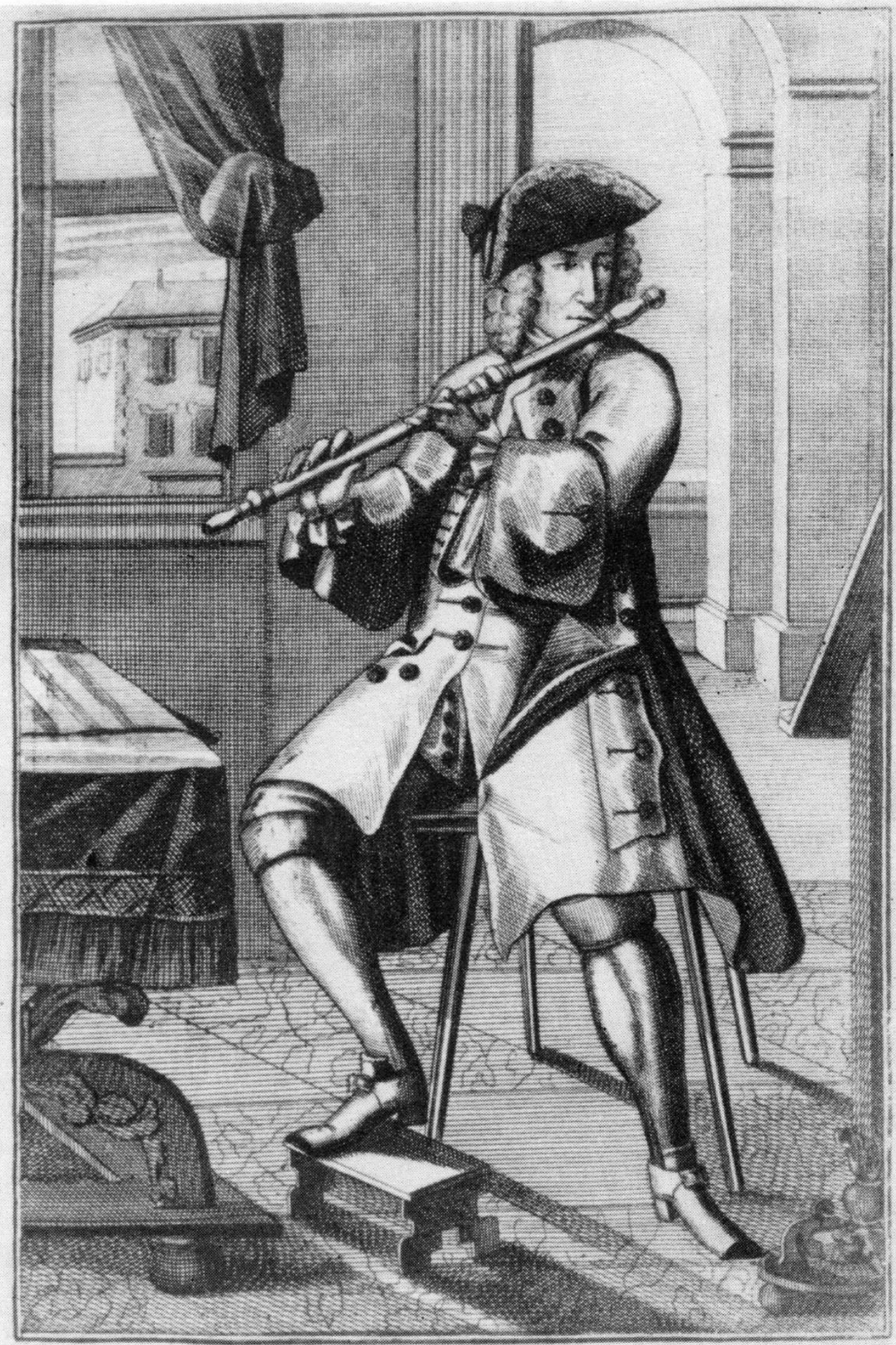

Tanch arofen Cayatier kan tch nach wrungch ergotzen

6 vvañ Mare nor Bht und Wuth bißscilen कnade gibt. fo kan Jen frajen Goift mein Schall in Ruthe fotzen ja faft bei jedermañ bin joh all zeit belicbt

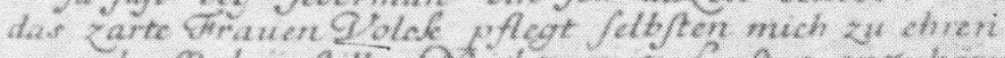
und oft beg filler Xiche mit Luften anzuhorer:

Fig. 34 - Gravura mostrando a Flauta Transversal (WEIGEL, ca. 1722) 


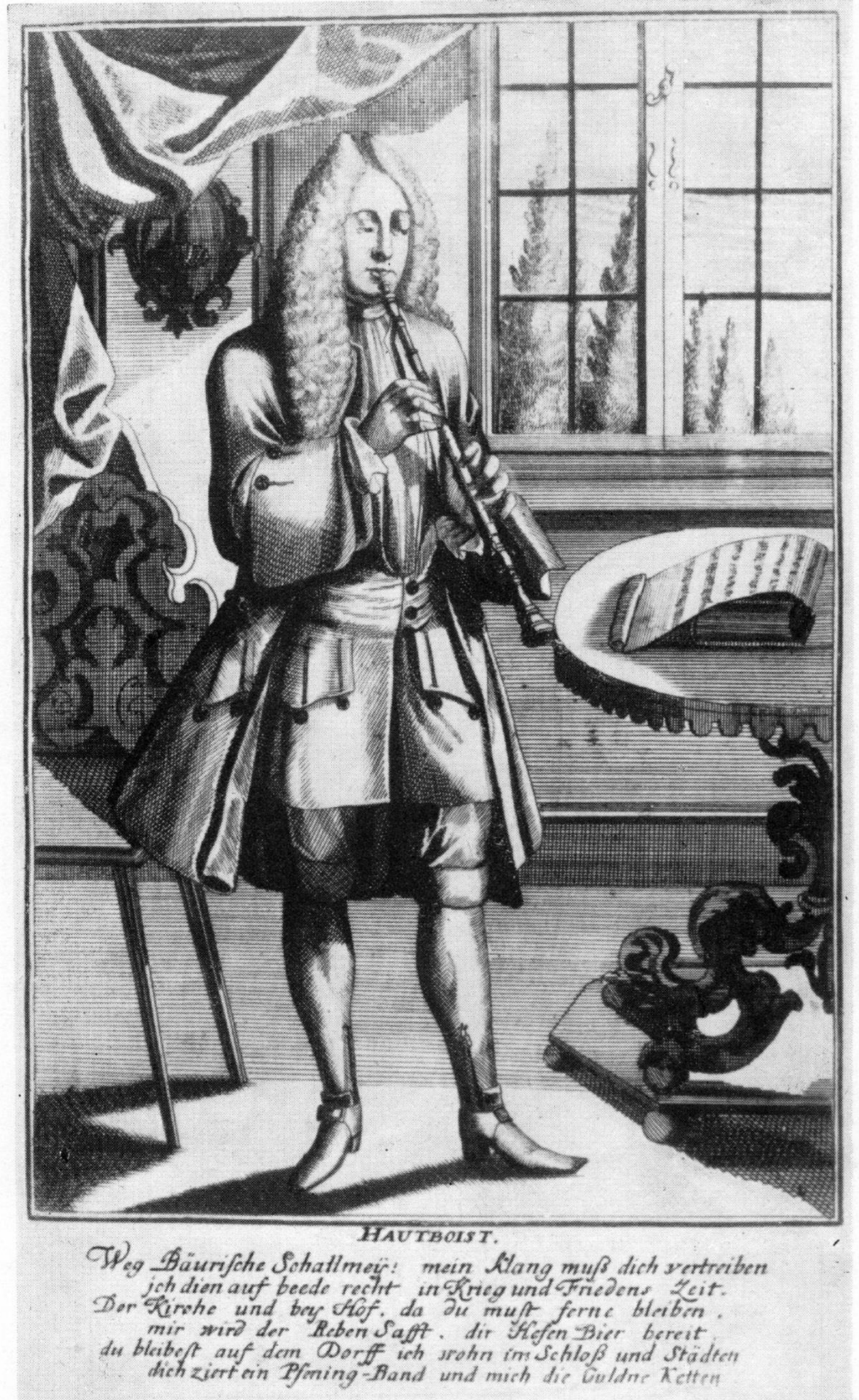

Fig. 35 - Gravura mostrando o Oboé (WEIGEL, ca. 1722) 


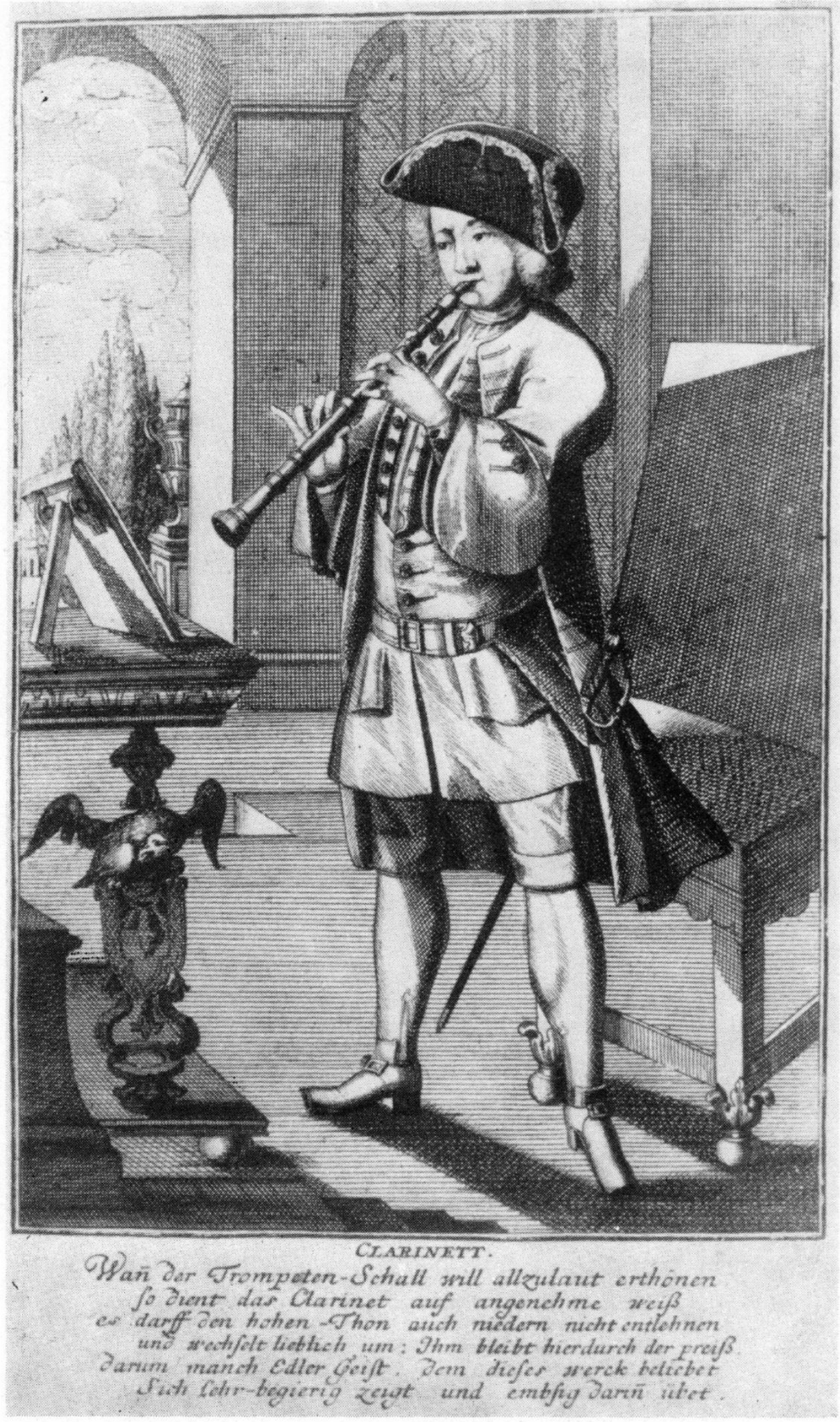

Fig. 36 - Gravura mostrando a Clarineta (WEIGEL, ca. 1722) 


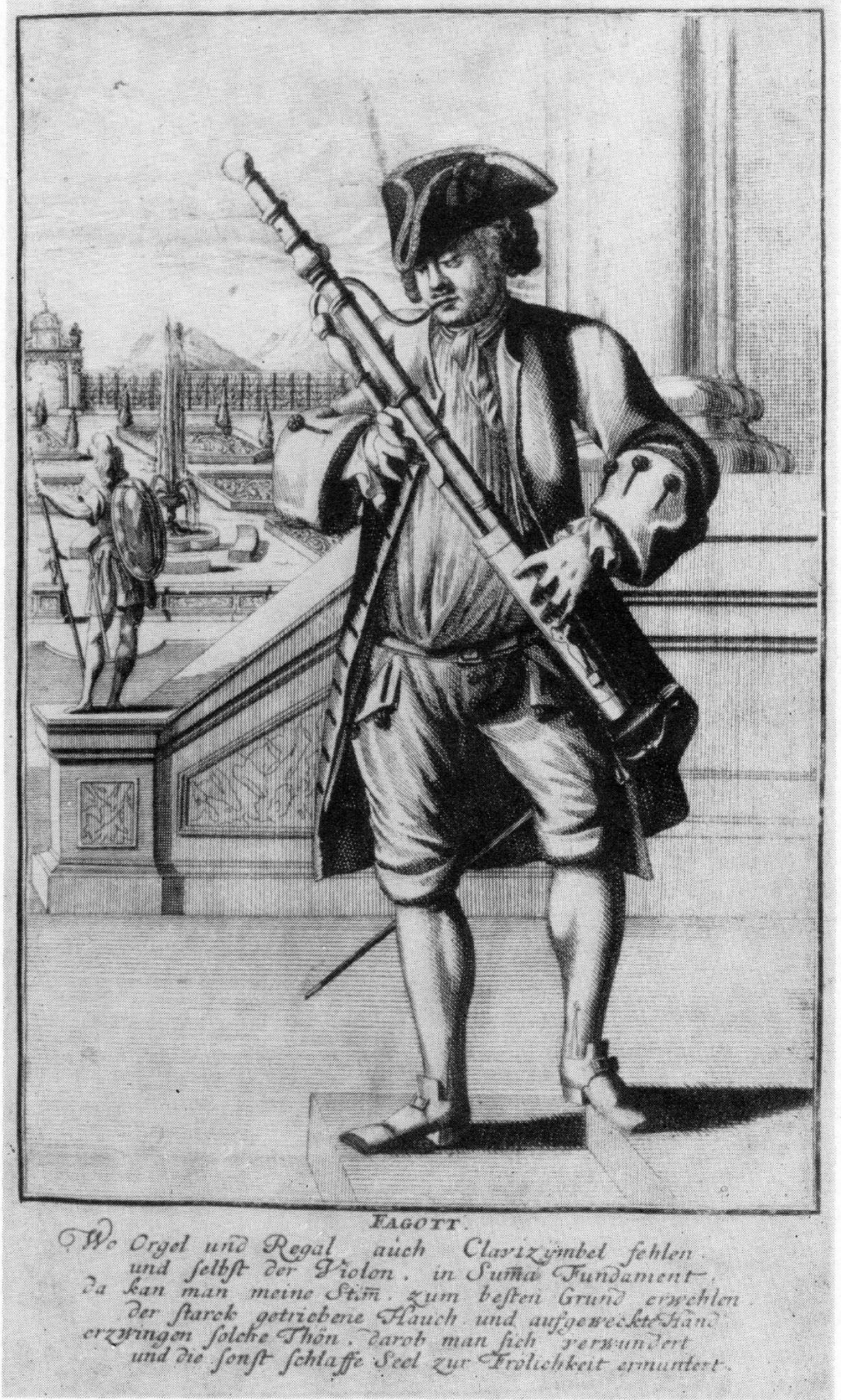

Fig. 37 - Gravura mostrando o Fagote (WEIGEL, ca. 1722) 


\author{
Flauta Doce \\ A doçura do som já indica o nome da flauta \\ Adequada para a cortesia nas noites estreladas \\ É ela que comove agradavelmente as damas \\ Quando para elas se toca uma serenata em calmo sossego \\ que saem da suave cama \\ Atraídas pelo doce som à sua janela
}

Curiosamente, de todas as gravuras do primeiro volume de Weigel, a referente à flauta doce é a única a mostrar um intérprete em posição de claro relaxamento, livre de perucas longas e chapéus pomposos. Sentado confortavelmente em uma cadeira, ele ainda apoia uma das pernas num banco enquanto toca o instrumento, sugerindo um momento de plena descontração. Isso, certamente, tem relação com o caráter do instrumento.

O poema discorre sobre a doçura do som dessa flauta e sobre sua capacidade de encantar o delicado ouvido feminino. Sendo assim, o instrumento é mostrado como fortemente propício à música suave e despretensiosa, em momentos de leveza e calmaria amorosa.

\title{
Flauta Transversal
}

Muitos grandes cavalheiros eu aprazo, de acordo com seu desejo

Quando Marte dá trégua de sangue e ira

E meu soar põe o espírito livre em paz

Sou amado por quase todos em todos os momentos

As doces mulheres do povo costumam me honrar

E frequentemente me ouvir com prazer na noite silenciosa 
O poema referente à flauta transversal denota, além das caraterísticas únicas do instrumento, também outras que sugerem comparação com a flauta doce, em suas semelhanças e diferenças. A primeira é mostrada, assim como a segunda, como um instrumento de som delicado, capaz de deleitar as mulheres em serenatas e diversas outras situações. No entanto, o texto também propõe a flauta transversal como um instrumento de maior profundidade e capacidade de causar transformação nos homens, pois além de ser "amada por quase todos em todos os momentos" (o que sugere o encantamento geral e não só das frivolidades femininas assim consideradas através do olhar machista da época), ela ainda teria o poder de acalmar o espírito humano, inclusive após momentos extremamente traumáticos como a guerra. De fato, o texto se refere à flauta transversal como instrumento muito popular e bem-quisto na época.

\section{Oboísta}

Fora, charamela camponesa! Meu som deve te expulsar

Eu sirvo bem no tempo de guerra e de paz.

Da igreja e da câmara deves ficar longe

me serve o suco da vinha e a cerveja fermentada.

Ficas na aldeia, e eu moro no castelo e nas cidades

a ti atrai uma fita de [valor de] vintém e a mim as correntes douradas.

Diferentemente dos outros poemas relativos aos instrumentos de sopro de madeira, o que trata do oboé parece ter como objetivo principal a exaltação do mesmo através da discriminação de outro, a charamela, da qual ele foi originado. Com visível arrogância, o texto recrimina o antigo instrumento e seu som então considerado pela nobreza como grosseiro, expulsando-o para os campos junto das classes sociais mais baixas. Fica então clara a visão contemporânea do oboé como um instrumento essencialmente aristocrático e também sua aceitação entre os nobres nos diversos ambientes nos quais sua música era feita, em seus diferentes gêneros e estilos. Apesar 
de sugerir sua versatilidade, o texto não trata mais profundamente do caráter do instrumento e de sua sonoridade. Além disso, é curioso o fato do título do poema mencionar "Oboísta" ao invés de "Oboé", uma vez que os outros recebem como título o nome de cada instrumento.

\section{Clarineta}

Quando o som do trompete é deveras alto

A clarineta serve para agradar

Evitando tanto os sons mais graves quanto os agudos

Ela varia graciosamente e então consegue seu prêmio.

Assim sendo, o espírito nobre, enamorado de sua palheta, Mostra-se ansioso por instrução e por praticar assiduamente.

Aqui, vê-se a confirmação da ideia setecentista que associa o som da clarineta ao do trompete. De fato, esse aspecto será mencionado outras vezes em documentos da época (falar-se-á sobre isso mais tarde). O então relativamente recente instrumento é citado com tendo sonoridade graciosa (se evitados seus registros extremos) e capaz de incitar em seus intérpretes uma grande vontade de tocá-lo.

\section{Fagote}

Onde faltam orgão, regal e cravo

E mesmo o violone - em resumo, o fundamento

Pode-se escolher minha voz como o melhor chão [fundamento]

O sopro fortemente impulsionado e a mão desperta

Resultam em um som que nos espanta

E acordam a alma, de outro modo adormecida, para a alegria 
O poema referindo-se ao fagote deixa claro o seu importante uso como instrumento do baixo-contínuo, juntamente ou no lugar de outros instrumentos normalmente empregados para o mesmo fim. O som do instrumento é descrito como surpreendente, capaz de alegrar as almas humanas.

A obra de Weigel, além de mostrar os modelos dos instrumentos de sopro de madeira mais usuais na Alemanha (e também em outros importantes países Europeus) do início do século XVIII, informa também sobre a posição nobre por eles então ocupada na música. Os instrumentos são apontados como dotados de caracteres, sendo que, em resumo, as flautas evocam sentimentos amorosos; o oboé é nobre, por excelência; a clarineta é suave e graciosa e o fagote, pomposo e alegre. A importância dada pelo autor a essas características pode clarificar a visão a seu respeito como lugares-comuns atribuídos aos instrumentos naquele local e período. Sendo assim, não há dúvida que o conhecido caráter e potencial expressivo extramusical desses instrumentos tenha sido considerado e aproveitado por artistas em suas obras. 


\subsection{Informações em escritos do século XVIII}

Comparadas, de forma geral, à quantidade relevante de documentação sobre música legada pelo século XVIII, as informações a respeito das características dos instrumentos nas quais se concentra esta tese parecem nela existir em volume muito discreto e de forma esparsa. Enquanto diversos aspectos relativos à música em si e ao fazer musical são abordados com profundidade por tratados, estudos, cartas e outros tipos de escritos setecentistas, o que diz respeito à visão e uso alegórico dos instrumentos é apenas, por vezes, citada em breves comentários cabendo em poucas frases ou parágrafos. Isso torna-se compreensível, em parte, devido ao grau de abstração e não-padronização geral que envolve a questão. Mas, por outro lado, chama a atenção a maneira parca através da qual ela é normalmente tratada, já que é possível perceber a importância dada a ela durante o século XVIII e épocas anteriores, como mostrado até agora. De qualquer modo, a pequena quantidade de citações relativas ao assunto encontradas ao longo dessa pesquisa não é de forma alguma menosprezável, contendo informações relevantes, através das quais pode-se ter uma aproximação da maneira como os sopros de madeira foram percebidos como detentores de diferentes caracteres e extramusicalmente contemplados no período.

Excertos de tratados e outros escritos de origem francesa são os que, aqui, se fazem mais presentes, compreendendo um período significativo do século XVIII e permitindo uma visão panorâmica da abordagem da questão na França ao longo da época.

François Raguenet é um dos que se dedicou a fazer apontamentos sobre a tão famosa questão setecentista envolvendo discussões a respeito das diferenças entre a música italiana e a francesa. Em 1702, ele publica o Parallèle des Italiens et des François en ce qui regarde la musique et les opéras, no qual compara, entre outras coisas, os tipos de instrumento e a maneira como são utilizados nos dois países (1702, p.17-19, tradução nossa):

Quanto aos instrumentos, nossos violinos estão acima dos da Itália, por sua fineza de construção e delicadeza do toque. Todos os golpes de arco dos italianos são muito duros quando são destacados uns dos outros; e quando querem ligá-los eles o fazem de uma maneira muito desagradável. Aliás, além de todos os tipos de instrumentos que são usados pelos italianos, nós 
temos ainda os oboés, que por seu som igualmente doce e penetrante, têm muita vantagem sobre os violinos nas árias de movimento; e as flautas que tantos ilustres sabem fazem gemer de maneira tão tocante nas árias lamentosas, e suspirar tão amorosamente em nossas árias ternas. ${ }^{133}$

O texto de Raguenet é claro ao exaltar a França e seu modo de fazer música, o que fica evidente no trecho a partir das críticas à maneira como os italianos constroem e tocam o violino. Além disso, Raguenet também enaltece os franceses por seus oboés e flautas, instrumentos que o autor dá a entender que à época ainda seriam mais comuns na França do que no território italiano. A sonoridade de ambos os instrumentos é ressaltada como especial em tipos distintos de árias, de diferentes qualidades, o que sugere também o caráter dos instrumentos em si. Quanto à flauta, o autor certamente se refere à flauta transversal barroca (ainda não popular na Itália no início do século XVIII), sendo que os "ilustres" citados no texto são revelados, em notas ao fim da publicação, como sendo Descoteaux, Philibert, os Hotteterre e Philidor, todos famosos intérpretes do traverso.

Sébastien de Brossard, em seu Dictionaire de musique, contenant une explication des Terms Grecs, Latins, Italiens, \& François les plus usitez dans la Musique (o primeiro dicionário do tipo em língua francesa), ao descrever diferentes "estilos" musicais, fala de um Stilo Symphoniaco, explicando (c.1708, p.136, tradução nossa):

É o Estilo próprio dos Instrumentos. E como cada Instrumento tem seu efeito particular, há também diferentes Estilos. O Estilo dos violinos, por exemplo, é ordinariamente alegre. Aquele das flautas, sobretudo as transversais, é triste, lânguido, etc. Aquele dos trompetes é animado, alegre, guerrilheiro, etc. ${ }^{134}$

Brossard esclarece que cada instrumento tem uma espécie de caráter distinto e que isso influencia diretamente na música que ele produz. Para o autor, tanto a flauta

\footnotetext{
133 "Quant aux instrumens, nos violons sont au-dessus de ceux d'Italie pour la finesse et la délicatesse du jeu. Tous les coups d'archet des Italiens sont tres-durs lors qu'ils sont détachez les uns des autres; et lors qu'ils les veulent lier, ils viellent d'une maniere tres-desagréable. D'ailleurs, outre toutes les sortes d'instrumens qui sont en usage parmi les Italiens, nous avons encore les Haut-bois qui, par leur son également moëlleux et perçant, ont tant d'avantage sur les violons dans les airs de mouvement; et les flûtes que tant d'illustres sçavent faire gémir d'une maniere si touchante dans nos airs plaintifs, et soupirer si amoureusement dans nos airs tendres.

134 "C'est le Stile propre pour les Instrumens. Et comme chaque Instrument a son effet particulier, il y a aussi différens Stiles. Le Stile des Violons, par exemple est ordinairement gay. celuy des Flûtes sur tout Traversieres est triste, languissant, et cetera celuy des Trompettes est animé, gay, guerrier, et cetera."
} 
doce como a transversal apresentam caráter semelhante, mas os efeitos da última parecem ser potencializados nas composições.

Fazendo uma crítica ferrenha aos caminhos tomados pela música francesa no período, Louis Bollioud de Mermet termina por reforçar a ideia de caráter dos instrumentos e de seu consequente efeito alegórico nas composições. Em De la corruption du goust dans la musique françoise, publicado em 1746, o autor afirma:

Tal é o abuso que se faz hoje do caráter de todos os instrumentos. A flauta, cuja propriedade consiste em formar os movimentos afetuosos e de sons sustentados, é agora empregada em articular batteries e roulades [ornamentações]. Os acentos delicados e sensuais do famoso Marais parecem ficar insípidos. A viola quer tocar as partes agudas, o violino os baixos. (1746, p.33-34, tradução nossa). ${ }^{135}$

Continuando a dissertar contra o emprego errôneo dos instrumentos, Bollioud de Mermet afirma ainda:

E não são somente os instrumentos mais comuns que têm o caráter disfarçado sob o pretexto de aperfeiçoamento. A vielle e a musette, próprias da música campestre, saem da espécie que as caracteriza. Destinadas à Pastoral e à Dança, elas entram nas Sinfonias comuns; e enquanto priva-se o sério e o delicado da flauta e da viola, transporta-se esses caracteres aos instrumentos rústicos, nos quais o patético e o afetuoso choram, e tornamse ridículos. (1746, p. 36-37, tradução nossa). ${ }^{136}$

Basicamente, o autor julga como grande erro o uso dos instrumentos que vai além de suas essências, ou ainda, que os tira de suas capacidades e caracteres mais primordiais, invertendo, assim, seus valores. Ao falar sobre a corrupção do emprego instrumental contemporâneo a si, o autor deixa subentendido o uso "correto" dos instrumentos num passado, reforçando assim a realidade de seu uso alegórico na música, a partir de seus diferentes potenciais.

\footnotetext{
135 “Tel est l'abus q'on fait aujourd'hui du caractère de tous les Instrumens. La Flute, dont la propriété consiste à former des mouvemens affectueux, et des sons soutenus, est employée maintenant à articuler des batteries et des roulades. Les accens tendres et séduisans du fameux Marais semblent devenir insipides. La Viole veut joüer des dessus, et le Violon des basses."

136 "II n'est pas jusqu'aux Instrumens les plus communs dont on ne déguise le caractère, sous prétexte de les perfectionner. La Vielle, la Musette, propres à la Musique champêtre, sortent de l'espéce qui les caractérise. Destinées à la Pastorale et à la Danse, elles entrent dans les Symphonies régulières; et tandis qu'on ôte le sérieux et le tendre à la Flute, à la Viole, on transporte ces caractères sur des Instrumens rustiques, où le pathétique et l'affectueux pleure, et devient ridicule."
} 
Em Fragments sur la musique en général et sur la notre en particulier, datado

de 1752, Jean Le Rond d'Alembert comenta a respeito de características da música instrumental e de como o uso dos instrumentos é importante no discurso de sons:

A música não é simplesmente um ruído agradável, ainda que muitas pessoas pareçam se limitar a essa ideia; é uma língua, ou uma espécie de língua feita para produzir algum sentimento na alma. Mas essa língua é tal, por ela mesma, que não pode despertar nada além de um sentimento deveras vago quando sozinha. O andamento e a natureza dos sons e aquela dos instrumentos são os três meios principais dos quais a música se serve quando não está junto das palavras; assim o andamento indica geralmente a animação, a lentidão do andamento junto à gravidade dos sons indica qualquer coisa de majestoso: a flauta é o instrumento da ternura, o fagote, por seu sons rasgados, é aquele da tristeza ou do horror. Daí, conclui-se que aquela que chamam sinfonia isolada, como uma sonata ou concerto, e que não é capaz de incitar na alma algum sentimento, é música muito ruim. (1887, p.182, tradução nossa). ${ }^{137}$

Vê-se que, para o autor, o caráter dos instrumentos é essencial para a música instrumental, contribuindo fortemente para a profundidade do discurso musical, fazendo com que qualidades associadas ao seu som contribuam para dar sentido à obra e desse modo torná-la capaz de tocar seus ouvintes.

Ainda a respeito da música instrumental, D'Alembert comenta:

Nota-se bastante como ela [a música] pode pintar uma tempestade, um ruído, mas preste-se atenção como ela pinta o sono: é dando à alma a quietude que o verdadeiro sono propaga; lembre-se do sucesso da abertura de Zélindor [ópera-ballet de Campra], é o gosto ligeiro e por assim dizer aéreo que a domina que fez sucesso. Embora não se pinte realmente o ar nem as sílfides, pode-se dar à música um caráter que lembre a ideia de uma sílfide ou de um corpo aéreo. Esse caráter consistirá no tempo vivo e alegre, na doçura dos sons, na feliz combinação das flautas e dos instrumentos de sopro, em uma sinfonia que pareça vir como uma nuvem. Será quase a mesma coisa se se quiser pintar a aurora ou o nascer do sol." (1887, p. 188189 , tradução nossa). ${ }^{138}$

\footnotetext{
137 "La musique n'est pas simplement un bruit agréable, quoique beaucoup de personnes semblent se borner à cette idée; c'est une langue ou une espèce de langue faite pour produire quelque sentiment dans l'âme. Mais cette langue est telle, par elle-même, qu'elle ne peut exciter tout au plus qu'un sentiment assez vauge, quand elle n'est jointe d'ailleurs à rien. La mesure et la nature des sons et celle des instrumens sont les trois moyens principaux dont la musique se sert quand elle n'est pas jointe à des paroles; ainsi la mesure indique en général la gayeté, la lenteur de la mesure, jointe à la gravité des sons, indique quelque chose de majestueux: la flûte est l'instrument de la tendresse, le basson, par ses sons déchirés, est celui de la tristesse ou de l'horreur. De là il suit d'abord que ce qu'on appelle symphonie isolée, comme sonate ou concerto, et qui n'est pas capable d'exciter dans l'âme quelque sentiment, est d'assez mauvaise musique."

138 "On sent assez comment elle peut peindre une tempête, un bruit, mais qu'on prenne garde comment elle peint un sommeil: c'est en donnant à l'âme la quiétude que le vrai sommeil répand; qu'on se
} 
Mais uma vez, os instrumentos são citados como parte da representação musical, auxiliando na formação de uma "paisagem sonora" que, mesmo puramente instrumental, pode claramente trazer imagens diretas ao público.

Charles-Henri de Blainville, em seu L'esprit de l'art musical, ou réflexions sur la musique et ses différentes parties, de 1754, ao comentar sobre lugares-comuns que determinado tipo de composição deveria apresentar, afirma:

Se é uma peça apreensiva, de dor, de abatimento, sabe-se que é preciso recorrer ao modo menor, pelos bemóis, o que traz um patético terno, triste e doloroso, mesclando, cuidadosamente, as flautas com os fagotes, mesmo as trompas, nos acompanhamentos. (1754, p. 76-77, tradução nossa) $)^{139}$

Mais uma vez, fica claro o dever da escolha de certos instrumentos para determinados fins expressivos, graças a seus respectivos efeitos alegóricos.

Como sugere o próprio título da obra de Ancelet, Observations sur la musique, les musiciens et les instruments, de 1757, o autor permite-se, aqui, falar sobre os instrumentos musicais de forma mais ampla. No que concerne os sopros de madeira, ele escreve:

\begin{abstract}
Se se quiser falar exatamente da flauta nesse capítulo, convém que ela não abrace todos os gêneros e caracteres da música, tais como as árias de fúrias, de guerreiros, de marinheiros e de muitos outros, nas quais ela não é ao menos empregada em principal: ela será, então, melhor colocada nas peças suaves e patéticas, nos acompanhamentos, nas pequenas árias e brunettes, que nas sonatas e concertos reservados aos melhores mestres, dos quais não devem, eles mesmos, abusar. Convenha-se também, sinceramente, que é muito difícil tocar esse instrumento de forma afinada. Eu acreditaria que isso seria de fato impraticável mesmo entre aqueles que o fazem há tempos, se o inimitável Blavet não tivesse me provado o contrário, fazendo-me escutar a execução de peças difíceis, escolhidas em todos os sustenidos e bemóis, que ele toca para a satisfação do mais escrupuloso ouvido: sua exatidão, sua embocadura plena e nutrida, e seu gosto conquistaram-Ihe o primeiro lugar. Entre os estrangeiros, P[B]uffardin foi um dos melhores que já escutamos. Vários outros, franceses, alemães e italianos se apresentaram com sucesso no Concert Spirituel e Taillard foi ali aplaudido com justiça. As pequenas flautas, mesmo os flageolets, serão úteis ao compositor quando
\end{abstract}

rappelle le succès de l'ouverture de Zélindor, c'est le goût léger et pour ainsy dire aérien qui y domine qui a fait ce succès. Cependant on ne peint point réellement l'air ni les sylphes, mais on peut donner à la musique un caractère qui rappelle l'idée d'un sylphe ou d'un corps aérien. Ce caractère consistera dans la mesure vive et légère, dans la douceur des sons, dans le mélange heureux des flûtes et des instrumens à vent, dans une symphonie qui paroîtra venir comme d'un nuage. II en sera à peu près de même si on veut peindre l'aurore ou le lever du soleil."

139 "Si c'est un morceau de crainte, de douleur, d'abattement, on sçait qu'il faut avoir recours au mode mineur, par les $b$ mols, ce qui donne un pathétique tendre, triste et douloureux, mêlant, avec ménagement, les flutes avec les bassons, même les cors dans les accompagnemens." 
ele os utilizar convenientemente. A duração de certas óperas nos prova a cada dia o quanto a variedade dos instrumentos lhes é necessária. Os oboés e os fagotes, pelo mesmo motivo, serão de grande utilidade àquele que compõe: ele deve empregar no seu quadro, quando ele é bem desenhado, a diferença de sons que se pode comparar à diversidade das cores, assim como o piano e o forte às sombras e às nuances: esse fato essencial é muito negligenciado em nossas Orquestras.

O oboé tem a qualidade do som terno, e da mesma forma marcial: ele deve ser empregado nas festas de guerra e campestres, assim como em certos acompanhamentos. Os melhores mestres franceses foram Philidor, Halé, Desjardins, Rault, pai e filho, Salentin e Bureau; entre os estrangeiros Besousi, Pla, Gniace, Prouver e Lavau.

Entre os fagotes, Belleville, Dubois, Blaise, Capel, Brunel, France, Saintsuir e sobretudo Besousi (...). Todas essas hábeis pessoas assemelham-se pelo capricho de sua embocadura. Não seria possível encontrar uma pomada salutar para os lábios daqueles que empregam tão generosamente seu peito a nossos prazeres? Ela ocuparia para eles o lugar do breu que os violinos adquirem a bom preço. (...)

As trompas agradam ainda mais quando acompanham as clarinetas, instrumentos ignorados até agora na França, que têm sobre nossos corações e nossos ouvidos direitos que nos eram desconhecidos. Que uso nossos compositores não poderiam delas fazer em sua música! (1757, p.27-30, 33, tradução nossa) ${ }^{140}$

140 "Si l'on veut parler exactement sur le chapitre de la Flûte, on conviendra qu'elle n'embrasse pas tous les genres et les caracteres de Musique, tels que sont les airs de Démons, de Furies, de Guerriers, de Tempêtes, de Matelots, et de plusieurs autres, dans lesquels elle n'est pas du moins employée en principal: elle sera donc mieux placée dans les morceaux tendres et pathetiques, dans les accompagnemens, dans les petits airs et les brunettes, que dans les Sonates et les Concerto réservés aux meilleurs Maîtres, qui ne doivent point eux-mêmes en abuser. On conviendra aussi, si l'on est sincere, qu'il est très-difficile de jouer juste de cet instrument. J'aurois cru même la chose impraticable à ceux qui ont exercé le plus longtems, si l'inimitable Blavet ne m'avoit prouvé le contraire, en l'entendant exécuter des morceaux difficiles, choisis dans les tons dieze et bémol, qu'il joue à la satisfaction complette de l'oreille la plus scrupuleuse: son exactitude, son embouchure pleine et nourrie, et son goût lui ont acquis la premiere place. Parmi les Etrangers, Pufardin a été un des meilleurs que nous ayons entendus. Quantité d'autres, François, Allemands et Italiens ont paru avec succès au Concert spirituel, et Taillard y a été applaudi avec justice. Les petites Flûtes, les Flageolets même seront utiles au compositeur quand il les placera à propos. La longueur de certains Opéra nous fait éprouver chaque jour, combien la variété des Instrumens leur est nécessaire. Les Hautbois et les Bassons, par le même endroit, seront d'une grande ressource à celui qui compose: il doit employer dans son tableau, quand il est bien dessiné, la différence des sons que l'on peut comparer à la diversité des couleurs, ainsi que le Piano et le Forte, aux ombres et aux nuances: cet article si essentiel est très-négligé dans nos Orchestres.

Le Hautbois a la qualité du son tendre, et cependant martiale: il doit être employé dans les fêtes guerrieres et champêtres, ainsi que dans certains accompagnemens. Les meilleurs Maîtres françois ont été Philidor, Halé, Desjardins, Rault, pere et fils, Salentin et Bureau; parmi les Etrangers Besousi, Pla, gniace, Prouver, et Lavau.

Parmi les Bassons, Belleville, Dubois, Blaise, Capel, Brunel, France, Saintsuir, et surtout Besousi (...). Tous ces habiles gens conviennent du caprice de leur embouchure: ne pourroit-on pas trouver une pommade salutaire pour les levres de ceux qui employent si généreusement leur poitrine à nos plaisirs? cela leur tiendroit lieu de la colophone que les Violons acheptent à si bon marché (...).

Les Cors de chasse plaisent encore davantage, quand ils accompagnent les Clarinettes, instrumens ignorés jusqu'ici en France, et qui ont sur nos coeurs et sur nos oreilles, des droits qui nous étoient inconnus. Quel emploi nos compositeurs n'en pourroient-ils pas faire dans leur Musique!" 
A quantidade de nomes de músicos citados por Ancelet chama a atenção. De fato, uma das intenções do autor é claramente mencionar grandes intérpretes de vários instrumentos por ele conhecidos (como mostra o próprio título da publicação). Além disso, o texto também fala sobre o caráter de alguns instrumentos e de seu uso alegórico (como é o caso da flauta e do oboé).

Por flauta, Ancelet certamente entende a flauta transversal, o que fica claro não só quando discute seu caráter e emprego musical mas também quando cita nomes de intérpretes famosos do instrumento. As indicações sobre o emprego do traverso em peças de caráter delicado, "suaves e patéticas", não difere das opiniões encontradas nos outros escritos aqui mencionados. No entanto, é interessante a citação dos tipos de árias na qual a flauta transversal não deveria ser utilizada. Curioso é o fato de Rameau, por exemplo, ter utilizado o instrumento de forma muito efetiva em cenas de tempestades e ventanias em algumas de suas óperas, cenas essas com as quais o caráter do instrumento não apresentaria, a princípio, compatibilidade. Desse modo, a orquestração da música das cenas de intempéries em Anacréon (1757) e Les Boréades (c.1763), por exemplo, poderia ter soado deveras surpreendente à época.

Ancelet não faz referência direta à flauta doce, talvez pelo fato de que em 1757 o instrumento já não desfrutava da mesma popularidade de períodos anteriores. Os flageolets que menciona são, muito provavelmente, instrumentos familiares a ela. No contexto do século XVIII, eram pequenos instrumentos de som agudo, muitas vezes utilizados para ensinar pássaros a cantar (daí o termo francês flageolet d'oiseau, que nomeava um de seus tipos). Possivelmente, eram considerados instrumentos de menor valor expressivo, uma vez que Ancelet afirma que até mesmo instrumentos como aqueles poderiam servir ao compositor que soubesse utilizá-los. Porém, por "petite flûte" o autor deve se referir a instrumentos da família da flauta transversal. Durante muito tempo, o termo "petite flûte" foi usado para designar as flautas doces soprano e sopranino. No entanto, à época da publicação de Ancelet, as pequenas flautas transversais já eram utilizadas com frequência na França, como afirma Corrette em seu Methode pour apprendre aisement à jouër de la Flute Traversiere: "Atualmente em Paris utiliza-se as pequenas flautas transversais à oitava que fazem um charmoso 
efeito nos tambourins e nos concertos feitos originalmente para a flauta". (c.1740, p.11, tradução nossa). ${ }^{141}$

A citação da clarineta é deveras especial aqui, uma vez que ela não costuma receber atenção em documentos franceses da época. De fato, o próprio Ancelet comenta que o instrumento ainda era desconhecido na França até aquele momento. $\mathrm{O}$ autor parece muito favorável à clarineta, sua sonoridade e potencial expressivo, citando a interessante combinação, muito utilizada no período, das clarinetas com as trompas.

Jean Laurent de Bethizy, em Exposition de la théorie e de la practique de la musique (1764), também fala dos instrumentos de sopro de madeira de forma um pouco mais extensa. No capítulo XVI do livro, o autor tece um comentário interessante sobre o caráter dos instrumentos ao falar de seu uso em acompanhamentos da voz:

Quanto à variedade dos acompanhamentos, a ela convém que sejam executados por instrumentos diferentes, por exemplo, pelas flautas, pelos violinos, e por um ou mais fagotes. O ouvido experimenta então um grande prazer se cada espécie de instrumento lhe oferece um canto de um gosto particular e conveniente ao seu caráter. Os Senhores Rameau e Mondonville bem compreenderam e ensinaram aos músicos qual partido se podia tirar da combinação dos instrumentos, e alguns aproveitaram bem as lições que esses autores famosos lhes deram em suas obras. (1764, p.273, tradução nossa) $)^{142}$

No capítulo XVIII, dedicado a comentários sobre as vozes e os instrumentos, Bethizy explana:

O som da flauta transversal é suave e triste. Ele convém à dor e à lamentação. (...) O som do oboé é alegre e convém, particularmente, aos divertissements campestres. (...) O fagote é o baixo natural dos oboés. Os sons desse instrumento são fortes e bruscos. Um homem hábil sabe, entretanto, como dele tirar sons muito doces, graciosos e suaves. Assim, além do uso comum que se faz desse instrumento, para executar os baixos contínuos, pode-se ainda, em uma peça graciosa ou suave ou mesmo lamentosa de música, seja ela instrumental ou vocal, fazer uma parte superior de fagote. Não há acompanhamentos mais belos que aqueles em que um autor sabe mesclar com gosto o som de um ou mais fagotes àqueles

\footnotetext{
141 "On fait presentemente a Paris des petites Flutes Traversieres a l'Octave qui font un effet charmant dans les Tambourins et dans les Concerto faits exprès pour la Flute."

142 “Quant à la variété des accompagnemens entr'eux, elle convient lorsqu'ils doivent être exécutés par des instrumens différens, par exemple, par des flûtes, par des violons, et par un ou plusieurs bassons. L'oreille éprouve alors un grand plaisir, si chaque espéce d'instrumens lui offre un chant d'un goût particulier et convenable à son caractére. Messieurs Rameau et Mondonville ont bien senti et ont appris aux Musiciens quel parti on pouvoit tirer du mélange des instrumens, et quelques-uns ont bien profité des leçons que ces Auteurs fameux leur ont données là-dessus dans leurs ouvrages."
} 
dos violinos e das flautas. A vestimenta que o fagote forma em direção ao agudo de sua extensão fazem um efeito admirável. O senhor Rameau e o senhor Mondonville deram os modelos perfeitos desses acompanhamentos, e devemos dizer, que por eles um instrumentos estimado somente pela força de seus sons, mostrou-se um instrumento agradável e tocante, capaz igualmente de dar prazer ao ouvido e de interessar o coração. (1764, p. 304306 , tradução nossa) $)^{143}$

O trecho dedicado ao fagote é sem dúvida o mais interessante, pois o autor escreve a respeito da dualidade de seus registros grave e agudo e como o seu uso pode trazer resultados puramente musicais e também alegóricos muito diferentes, levando o instrumento da aspereza à delicadeza. Rameau e Mondonville são novamente citados como os mestres do uso do registro agudo do fagote, sendo para o autor os responsáveis por trazer a público o efeito por ele causado.

Denis Diderot foi responsável pelo verbete da Encyclopédie a respeito dos instrumentos musicais. Após definir a ideia de instrumento e de enumerar seus diferentes tipos, o autor continua:

Observaremos (...) que cada instrumento tem sua extensão própria, sua
expressão e seu caráter que o músico deve conhecer bem. Se ele leva o
instrumento além de sua verdadeira extensão, ele o torna acentuado, surdo
ou gritante. Se não conhece sua expressão, ele não o aplicará nas
circunstâncias em que terá mais efeito. É uma parte muito importante do
estudo de um compositor, aquela do caráter dos instrumentos. São as
diferentes vozes através das quais ele fala a nossos ouvidos. Mas não basta
conhecer cada instrumento em particular; é preciso ter ainda a experiência
de seus sons combinados entre si: às vezes não é preciso mais que uma nota
bem empregada de uma trompa, para causar a mais violenta das emoções.
Não há fenômeno na natureza, nem emoções, nem sentimentos no coração
do homem que não se possa imitar com um mesmo instrumento; mas não
se pode dizer que eles sejam todos igualmente próprios a todas essas
imitações. Se os sons agudos das pequenas flautas se fazem ouvir por
intervalos na pintura de uma tempestade, eles lhe darão muita veracidade.
Os sons graves e lúgubres das trompas anunciarão de uma maneira

143 "Le son de la flûte allemande est tendre et triste. II convient à la douleur et aux plaintes. (...) Le son du hautbois est guai et convient particuliérement aux divertissemens champêtres. (...) Le basson est la basse naturelle des hautbois. Les sons de cet instrument sont forts et brusques. Un habile homme en sçait néanmoins tirer des sons très-doux, très-gracieux et très-tendres. Ainsi, outre l'usage ordinaire qu'on fait de cet instrument, pour exécuter des basses continues, on peut encore dans un morceau gracieux ou tendre ou même plaintif de musique soit instrumentale soit vocale, faire une partie supérieure de basson. II n'y a point d'accompagnemens plus beaux, que ceux où un Auteur sçait mêler avec goût les sons d'un ou de plusieurs bassons à ceux des violons et des flùtes. Les tenues que le basson y forme vers le haut de son étendue, font un effet admirable. Monsieur Rameau et Monsieur Mondonville ont donné de parfaits modeles de ces accompagnemens, et on leur a cette obligation, que par eux un instrument estimé seulement pour la force de ses sons, a paru un instrument agréable et touchant, capable également de plaire à l'oreille et d'intéresser le coeur." 
assustadora a chegada de espectros e sombras; é necessário às vezes sustentar os sons dos instrumentos de cordas, às vezes pinçá-los, etc. (1765, p. 804 , tradução nossa) $)^{144}$

Diderot fala a respeito da necessidade do compositor conhecer bem as características individuais de cada instrumento, a fim de poder utilizá-lo de forma efetiva em suas composições, e reforça a ideia de que cada instrumento teria um caráter individual e que por isso seria mais propenso ao uso em determinadas representações do que outros.

O famoso Dictionnaire de Musique de Jean-Jacques Rousseau, com primeira publicação em 1768, não contém verbetes específicos para cada um dos instrumentos musicais. De maneira geral, eles são citados em meio às explicações de outros termos. No verbete que define "Expressão", Rousseau fala sobre o caráter e efeitos dos instrumentos:

\begin{abstract}
Expressão, substantivo feminino. Qualidade pela qual o músico sente vivamente e entrega com energia todas as ideias que ele deve mostrar, e todos os sentimentos que ele deve exprimir. Há uma expressão de composição e uma de execução, e é o conjunto das duas que resulta no afeto musical mais potente e mais agradável (...)

Os instrumentos têm também expressões muito diferentes, dependendo se seu som for forte ou fraco, se seu timbre for acre ou doce, se o diapasão for grave ou agudo, e se é possível obter neles os sons em maior ou menor quantidade. A flauta é terna, o oboé alegre, o trompete guerreiro, a trompa sonora, majestosa, própria a grandes expressões. (1768, p.214-215, tradução nossa) $)^{145}$
\end{abstract}

\footnotetext{
144 "Nous observerons (...) que chaque instrument a son étendue propre, son expression \& son caractere que le musicien doit bien connoître. S'il porte l'instrument au-delà de sa véritable étendue, il le rendra aigu, sourd ou criard. S'il ne connoît pas son expression, il ne l'appliquera pas dans les circonstances où il aura le plus d'effet. C'est une partie très-importante de l'étude d'un compositeur, que celle du caractere des instrumens. Ce sont les voix différentes par lesquelles il parle à nos oreilles. Mais ce n'est pas assez que de connoître chaque instrument en particulier; il faut encore avoir l'expérience de l'effet de leurs sons combinés entr'eux: il ne faut quelquefois qu'une note de cors bien placée, pour causer l'émotion la plus violente. II n'y a point de phénomenes dans la nature, point de passions, point de sentimens dans le coeur de l'homme, qu'on ne puisse imiter avec le même instrument; mais on ne peut pas dire qu'ils soient tous également propres à toutes ces imitations. Si les sons aigus des petites flutes se font entendre par intervalles dans la peinture d'une tempête, ils lui donneront beaucoup de vérité. Les sons bas \& lugubres des cors annonceront d'une maniere effrayante l'arrivée des spectres \& des ombres; il faut tantôt soutenir les sons des instrumens à corde, tantôt les pincer, \&c."

145 "Expression, substantif féminin. Qualité par laquelle le musicien sent vivement et rend avec énergie toutes les idées qu'il doit rendre, et tous les sentiments qu'il doit exprimer. II y a une expression de composition et une d'exécution, et c'est de leur concours que résulte l'effet musical le plus puissant et le plus agréable. (...)

Les instruments ont aussi des expressions très-différentes selon que le son en est fort ou faible, que le timbre en est aigre ou doux, que le diapason en est grave ou aigu, et qu'on en peut tirer des sons en plus
} 
Ao falar de diferentes expressões instrumentais, Rousseau deixa claro que as mesmas surgem a partir das características e possibilidades sonoras de cada instrumento, que definem seu caráter expressivo.

O conteúdo do livro de memórias de André Ernest Modeste Grétry, datado de 1789, vai além das lembranças de acontecimentos vivenciados pelo músico. O compositor deixa ali registrada, também, uma série de opiniões e críticas a respeito da música, o que explica o título da publicação: "Memórias ou Ensaio sobre a Música" [itálico ou aspas]. Ao dissertar sobre o uso dos instrumentos no gênero operístico, o autor afirma:

O emprego dos instrumentos de sopro muito bem compreendido pelos alemães, em relação à harmonia, merece ser considerado pelos compositores dramáticos. Quando a música não declamava, uma flauta transversal, um trompete, uma trompa queriam dizer amor, glória ou a caça. É necessário, no presente, que esses diversos instrumentos unam-se a favor da expressão.

É possível olhar para esses instrumentos acompanhadores do canto de duas maneiras. Uma em relação à voz que eles acompanham e outra relacionada ao sentimento do texto que a música exprime. O fagote é lúgubre, e deve ser empregado no patético, mesmo quando deseja-se fazer sentir apenas uma delicada nuance; ele me parece um contra-senso em tudo aquilo que é de pura alegria. A clarineta convém à dor, embora menos patética que o fagote. Quando ela executa árias alegres, ela mistura a elas uma tinta de tristeza. Se se dançasse em uma prisão, eu gostaria que fosse ao som da clarineta. O oboé, campestre e alegre, serve também para indicar um raio de esperança em meio aos tormentos. A flauta transversal é terna e amorosa; a doçura de seus sons amarga a mais bela das vozes femininas, que não pode de forma alguma se sustentar ao lado da flauta; ela acompanha de forma mais vantajosa as vozes masculinas e os instrumentos cujo som não é sustentado. (1789, p. 278-9, tradução nossa) ${ }^{146}$

grande ou moindre quantité. La flûte est tendre, le hautbois gai, la trompette guerrière, le cor sonore, majestueux, propre aux grandes expressions."

146 "L'empli des instrumens à vent si bien senti par les Allemands, par rapport à l'harmonie, mérite d'être considéré par les compositeurs dramatiques. Lorsque la musique ne déclamoit point une flûte traversière, une trompette, um cor, vouloient dire amour, gloire, ou la chasse. Il faut à présent que ce divers instrumens concourent à l'expression.

On peut regarder ces Instrumens accompagnateurs du chant sous deux rapports. Celui de la voix qu'ils accompagnent \& le sentimento des paroles quela musique exprime. Le basson est lugubre, \& doit être employé dans le pathétique, lors même qu'on veut n'en faire sentir qu'une nuance délicate; il me paroît un contre-sens dans tout ce qui est de pure gaîté. La clarinette convient à la douleur, moins pathétique cependant que le basson. Lorqu'elle exécute des airs gais, elle y mêle encore une teinte de tristesse. Si I'on dansoit dans une prison, je voudrois que ce fût au son de la clarinette. Le hautbois, champêtre \& gai, sert aussi à indiquer un rayon d'espoir au milieu des tourmens. La flûte traversière est tendre \& amoureuse; la douceur de ses sons aigrit la plus belle voix de femme, qui ne peut guère se soutenir à côté de la flute; ele accompagne plus avantageusement la voix des hommes \& les instrumens dont le son n'est pas soutenu." 
Grétry, a princípio, parece convicto em relação ao repúdio do uso dos instrumentos de sopro como representantes muito diretos de determinado aspecto extramusical. O compositor fala desse tipo de emprego como ligado a uma música sem capacidade de declamação, possivelmente entendendo o mesmo como um efeito artificial e ultrapassado. Fazendo parte de um período do século XVIII no qual as formações orquestrais já caminhavam em uma direção de padronização que culminaria na orquestra clássica beethoveniana, a autor comenta a respeito da necessidade de unir os instrumentos e seus sons para que se obtenha uma "maior expressão". Para Grétry, assim como para Rousseau, os instrumentos de sopro têm, claramente, caracteres muito bem definidos por suas diferentes sonoridades. $\mathrm{Na}$ música dramática, eles deveriam, portanto, ser empregados principalmente de acordo com os afetos relacionados ao texto das árias, utilizando seus timbres característicos em favor dos mesmos.

Como se vê em praticamente todas as citações dos autores anteriormente mencionadas, parece haver uma tendência a caracterizar os instrumentos e sistematizar seu uso mais em relação à sua sonoridade do que a outras conotações extramusicais (como sua utilização prática tradicional, por exemplo). Não obstante, essas últimas não se fazem completamente ausentes. De qualquer modo, pode-se pensar que mesmo quando utilizados puramente devido a seu caráter sonoro, os instrumentos não deixavam de tomar o papel de alegorias.

O som pode ser caracterizado por sua intensidade, sua altura, sua duração e sua cor $^{147}$. Desse modo, é possível, por exemplo, dizer que determinado instrumento é, devido a seu som, suave, se comparado a outro capaz de maior volume sonoro ou de timbre mais ríspido. No entanto, atribuir ao som de um instrumento características como alegria, tristeza, amorosidade, etc, mostra-se como algo deveras relativo, muito conectado ao gosto pessoal ou ainda a uma tradição ou modo de se vislumbrar e utilizar os instrumentos de acordo com aquelas características (que são, aliás, também extramusicais). Assim, um instrumento de som "amoroso" pode ser uma alegoria para

\footnotetext{
147 As discussões setecentistas científicas a respeito do timbre dos instrumentos não são muito numerosas, uma vez que as explicações para esse atributo do som só seriam dadas de forma mais clara no século XIX, com as teorias de Helmhotz. De qualquer forma, vê-se que os adjetivos usados pelos autores a fim de caracterizar os instrumentos estão intimamente ligados às qualidades timbrísticas dos mesmos.
} 
o amor; outro de som alegre, uma alegoria para a alegria ou outros afetos relacionados, e assim por diante. Além disso, as citações mostradas tendem a caracterizar os instrumentos, ainda que não de uma forma idêntica, de maneira muito similar, o que sugere também o desenvolvimento de um tipo de tradição de contemplação das diferentes sonoridades instrumentais ao longo do século XVIII, se não anterior.

Nota-se que Grétry, mesmo parecendo criticar a utilização dos instrumentos por conotações extramusicais tradicionais, acaba por se contradizer ao caracterizar 0 oboé como "campestre", já que a concepção dessa característica vai além de seu caráter "alegre", necessitando de diversos outros parâmetros históricos e culturais para ser formada. Também é válido lembrar que as afirmações de Grétry devem ser lidas no contexto de fins do século XVIII, podendo não corresponder à visão dos mesmos aspectos em momentos anteriores do período.

Fora do território francês, o poeta e filósofo escocês James Beattie deixou alguns escritos sobre música nos quais flerta com a questão do uso dos instrumentos musicais. Em 1762, em seu Essay on Poetry and Music, as they affect the mind, ao tratar da questão da imitação na música, Beattie escreve:

Enfim, deve ser reconhecido, que há alguma relação ao menos, ou analogia, senão similaridade, entre certos sons musicais, e afetos mentais. Música suave pode ser considerada como análoga a emoções gentis; e música estrondosa, se os tons são doces e não muito rápidos, às sublimes; e uma sucessão de notas barulhentas, como aquelas que ouvimos de um tambor, parecem ter alguma relação à pressa e impetuosidade da paixão. Algumas vezes, também, há proveniente da natureza, e outras vezes vinda do costume, uma conexão entre certos instrumentos musicais, e certos lugares e ocasiões. Assim, uma flauta, oboé ou gaita-de-foles, é melhor adaptada aos propósitos da música rural, que um violino, órgão ou cravo, por ser mais portátil, e menos sujeita às injúrias do clima: assim, um órgão, devido tanto a seu tamanho como a sua potência sonora, requer ser colocado em uma igreja, ou algum grande apartamento: assim, violinos e violoncelos, aos quais qualquer grau de umidade pode se provar danoso, são naturalmente adaptados ao uso doméstico; enquanto tambores e trompetes, pífaros e trompas, são mais adequados ao serviço campestre. Por isso acontece, que sons e modos musicais adquirem tal conexão com locais, ocasiões e sentimentos particulares, que ao ouvir os primeiros nos lembramos dos últimos, e somos por eles mais ou menos afetados, de acordo com as circunstâncias. O som de um órgão, por exemplo, remete a uma igreja, e aos afetos adequadas ao lugar; música militar, a ideias militares; e flautas e oboés, a pensamentos e ideias peculiares à vida rural. Isso pode servir em partes para somar à expressividade ou eficácia musicais; ou seja, para 
explicar como ocorre que certas paixões sejam afloradas, ou certas ideias sugeridas por certos tipos de música. (1778, p. 143-144, tradução nossa) $)^{148}$

O texto de Beattie reforça a ideia de que alguns instrumentos carregavam consigo uma série de associações extramusicais, fosse em relação à sua sonoridade e constituição (natureza) ou às suas origens, históricos de uso e funções tradicionais (costumes). Assim, essas associações os tornavam inevitavelmente conectados a "locais, ocasiões e pensamentos" particulares a cada um e isso era refletido na música na qual fossem utilizados, em prol de sua expressão.

Entre os alemães do século XVIII que legaram escritos sobre o assunto, uma das figuras mais relevantes é a do músico e tratadista Johann Mattheson. Como visto anteriormente, as opiniões do autor a respeito dos instrumentos musicais foram, muito provavelmente, a inspiração para o Musikalische Theatrum de Weigel. Essas opiniões encontram-se no Das Neu-Eröffnete Orchestre, publicado em 1713. É no terceiro capítulo da terceira parte do tratado que Mattheson descreve os instrumentos e suas características. Sobre os sopros de madeira, Mattheson escreve:

O eloquente oboé, ital. oboe, é, entre os franceses, equivalente ao instrumento conhecido na Alemanha como schalmey (denominados pifferi pelos músicos antigos), embora tenha algumas diferenças. Os hautbois são os que mais se aproximam da voz humana, atrás da flute allemande [flauta transversal], quando são usados com esmero e de modo cantabile, coisas que requerem grande habitus e muito da arte do canto. Se os hautbois não forem tocados com toda a delicadeza (como não se faz, por exemplo, no campo ou em festejos com bebidas, onde nem sempre são abordados muito

\footnotetext{
148 "After all, it must be acknowledged, that there is some relation at least, or analogy, if not similitude, between certain musical sounds, and mental affections. Soft music may be considered as analogous to gentle emotions; and loud music, if the tones are sweet and not too rapid, to sublime ones; and a quick succesion of noisy notes, like those we hear from a drum, seems to have some relation to hurry and impetuosity of passion. Sometimes, too, there is from nature, and sometimes there comes to be from custom, a connection between certain musical instruments, and certain places and occasions. Thus a flute, hautboy, or bagpipe, is better adapted to the purposes of rural music, than a fiddle, organ, or harpsichord, because more portable, and less liable to injury from the weather: thus an organ, on account both of its size and loudness, requires to be placed in a church, or some large apartment: thus violins and violoncelos, to which any degree of damp may prove hurtful, are naturally adapted to domestic use; while drums and trumpets, fifes and french-horns, are better suited to services on the field. Hence it happens, that particular tones and modes of music acquire such a connection with particular places, occasions, and sentiments, that by hearing the former we are put in mind of the later, so as to be affected with them more or less, according to the circumstances. The sound of an organ, for example, puts one in mind of a church, and of the affections suitable to that place; military music, of military ideas; and flutes and hauboys, of the thoughts and images peculiar to rural life. This may serve in part to account for musical expressiveness or efficacy; that is, to explain how it comes to pass, that certain passions are raised, or certain ideas suggested, by certain kinds of music."
} 
meticulosamente) eu preferiria ouvir um berimbau de boca ou um pente [lamelofone], e seria, acredito, melhor entretido. A extensão tem duas oitavas desde o dó3 até o ré5.

O fagote orgulhoso, basse de chromorne, ital. fagotto, vulgo dulcian, é o baixo ordinário, o fundamento ou acompanhamento do hautbois. Ele é mais fácil de tocar, pois não requer a mesma finesse e maneiras (mas outras); mas quem quiser se destacar neste, deverá achar trabalhoso conseguir as notas agudas, delicadeza e rapidez. Especialmente no fagote e no oboé é preciso ter palhetas boas, e os melhores mestres as constroem de modo a melhor adaptá-las às suas bocas, pois uma boa palheta é metade da execução. 0 escopo do fagote tem 3 oitavas e meia, do dó1 até o fá ou sol3. Às vezes, eles ainda têm o si bemol e lá graves. As bombardi, que os antigos utilizavam ao invés do fagote, não estão mais na moda. (...)

As flautas da moda existem em diversos tipos, mas nenhuma, além das que menciono aqui, merece atenção. São elas a flute allemande, ou d'allemagne, traversiere, teutsche ou Quer-flöte, que são uma só, e as conhecidas flautas doces, de diversos calibres. O primeiro é o instrumento que, de acordo com o dizer dos entendidos, mais se assemelha a uma voz humana moderada (e não rude), quando é tocado com juízo, e é tido em alta estima. A embocadura é algo difícil, a extensão é como a do oboé, exceto o dó3, que a flute allemande não tem. As tonalidades de sol maior, lá maior, ré maior, mi menor etc. favorecem especialmente o instrumento. Das flautas doces, ital. flauti, temos três tipos principais. Uma delas tem o âmbito do fá3 até o fá5, a flauta discant; a outra do dó3 até o dó5, denominada flauta alto e a terceira, que é ingenuamente chamada de flauta-baixo, do fá2 ao fá4. Apesar de todo o esforço, não foi possível construir flautas mais graves. A língua tem o melhor desempenho nestes instrumentos, quando é ágil e flexível, pois ela deve marcar os tons. Um [músico], de nome Hotteterre, se deu ao trabalho de escrever dois ou três pequenos tratados sobre a flûte traversière, a flûte à bec ou flûte douce, e o hautbois, os quais não serão inúteis ao amador. Embora uma flauta doce aparente ser um instrumento leve, ela fatiga tanto o instrumentista quanto o ouvinte quando é ouvida por tempo demais. Pois, em primeiro lugar, a flauta necessita de muito mais ar que um fagote, oboé ou flauta transversal, e em segundo, porque sua característica delicada e monótona causa rapidamente fastio e cansaço. Deve-se creditar o assim denominado chalumeau por carregar consigo algo como uma chorosa symphonie das noites de junho ou julho, nunca de janeiro, sobre a água, e por ser adequado a serenatas e a ser ouvido de longe. Os finos flageolets são úteis para os apitadores e àqueles que têm paciência suficiente e desejam aprender o assobio dos pássaros, imitando-os com propriedade. (1713, p. 268-272, tradução nossa) $)^{149}$

149 "Der gleichsam redende Hautbois, Ital. Oboe, ist bey den Franzosen / und nunmehro auch bey uns / das / was vor diesem in Teutschland die Schalmeyen (von den alten Musicis Piffari genannt) gewesen sind / ob sie gleich etwas anders eingerichtet. Die Hautbois kommen / nach der Flute Allemande, der Menschen-Stimme wol am nähesten / wenn sie mannierlich und nach der Sing-Art tractirt werden / wozu ein großer Habitus und sonderlich die ganze Wissenschaft der Singe-Kunst gehöret. Werden aber die Hautbois nicht auf das aller delicateste angeblasen / (es sey denn im Felde oder inter pocula, wo mans eben so genau nicht nimmt) so will ich lieber eine gute Maultrommel oder ein Kamm=Stückchen davor hören / und glaube / es werden ihrer mehr also verwehnet seyn. Die Etendüe hat 2. Octaven vom c1 bis c3. auch wol d3.

Der stoltze Basson, Basse de Chormorne, Ital. Fagotto, vulgò Dulcian, ist der ordinaire Bass, das Fundament oder Accompagnement der Hautbois. Er soll zwar leichter zu spielen seyn / als jene / weil er eben nicht dieselbe Finesse noch Mannieren (aber wol andere) erfordert; allein / wer sich darauff signaliren will / wird auch schon / insonderheit in der Höhe / Zierlichkeit und Geschwindigkeit seine volle Arbeit finden. Man hat sich insonderheit bey Bassons und Hautbois auff gute Röhre zu richten / und die besten Maitres pflegen sie sich selber nach ihrem Maul zu machen / weil ein gutes Rohr halb 
Vê-se que Mattheson faz descrições interessantes dos instrumentos, abordando de forma moderada aspectos diversos como extensão, modo de tocar e uso aplicado. Não é surpreendente, no entanto, o fato do autor não se dedicar muito a abordagens das possibilidades extramusicais. Contudo, Mattheson deixa em seu texto algumas pistas a respeito de sua opinião sobre elas, em relação a alguns instrumentos e seus caracteres próprios. Desse modo, o oboé é para ele "eloquente" e o fagote "orgulhoso". O autor não descreve a clarineta, mas sim o chalumeau, dela instrumento-irmão no início do século XVIII, que teria como característica uma delicada sonoridade "chorosa".

Décadas após Mattheson, Christian Friedrich Daniel Schubart fará alguns apontamentos relevantes sobre os instrumentos em seu Ideen zu einer Ästhetik der Tonkunst (1784-5). Na segunda parte da obra, que aborda diversos princípios da música, há um capítulo dedicado a explanações a respeito de vários instrumentos musicais. O texto de Schubart, assim como o de Mattheson, abrange diferentes aspectos, mas em relação a alguns instrumentos mostra-se um pouco mais profundo no que diz respeito a seu caráter. Algumas das informações sobre a história de cada

gespielet ist. Der Ambitus des Bassons begreifft drittehalb Octaven vom C. biß f1. und g1. Bisweilen haben sie auch wol das contra B. und A. dazu. Die Bombardi, deren man sich vor Alters an statt der Bassons bedienet / sind itzt nicht mehr Mode. (...)

Der modesten Flöten gibt es zwar vielerley Arten / doch verdienen keine so wol dass man von ihnen allhier rede / als die Flute Allemande, oder d'Allemagne, Traversiere, Teutsche oder Quer=Flöte / welches einerley / und die bekanten Flute douces von allerhand Calibre. Die erste ist das Instrument, welches / verständigem Anspruch nach / einer moderirten Menschen Stimme (nicht aber eines blöckenden Küsters seiner) am allernähesten kommen will / und folglich / wenn es mit Jugement gespielet wird / hoch zu estimiren ist. Der Ansatz wird was difficiles haben / ehe man ihn erlanget; die Etendüe ist wie auf dem Hautbois, ausser dem c1. welches die Flute Allemande unten nicht hat. Die Tohne g. dur. a. dur. d. dur. e. moll. \&c. favorisiren demselben Instrument insonderheit. Von Flutes douces, Ital. Flauti hat man vornemlich dreyerley Sorten. Eine deren Ambitus vom f1. ins f3. welches die Discant-Flöte; die andere vom c1. ins c3. so man Alt-Flöten heisset / und die dritte / welche unschuldiger Weise Bass-Flöten genennet werden / von f. ins f2. Tieffer hat mans / aller Mühe ungeachtet / auf den Flöten noch nicht bringen können. Die Zunge thut wol das beste ben diesen Instrumenten, wenn sie sehr sertig und flexible ist / denn sie muss alle tohne marquiren. / Es hat sich einer / mit Nahmen Hotteterre, in Franckreich die Mühe genommen / zwey oder drey kleine Tractaten von der Flute Traversiere, von der Flute à bec, oder Flute douce it. von dem Hautbois zu schreiben / welche einem Liebhaber keine unnütze handreichung thut mögen. Ob nun gleich eine solche Flute douce das allerleichteste Instrument ist und scheinet / so fatiguiret es doch den Spieler so wol als den Zuhörer / wenn es sich zu lange hören läst. Denn dem ersten kostet eine Flöte vielmehr Wind als ein Basson, Hautbois, oder Traversiere; und der andere kan ihrer / wegen der sanfften und kriechenden Eigenschafft leicht müde und überdrüssig werden. Den so genandten Chalumeaux mag vergönnet seyn / dass sie sich mit ihrer etwas heulende Symphonie des Abends etwann im Junio oder Julio, niemahls aber im Januario auff dem Wasser zum Ständchen / und zwar von weiten / hören lassen. Die dünnen Flageolets aber / will man dem Voglern / und denen / die Gedult genug haben / den Vögeln pfeiffen zu lernen / eigentühm=und erblich vermachen." 
instrumento são errôneas ou contestáveis, mas a opinião do autor sobre suas possibilidades expressivas chama a atenção.

Sobre o oboé, Schubart escreve (DUBOIS, 1983, p. 374, tradução nossa):

(...) tem sido usado em todos os tipos de música, e gênios de primeira grandeza trouxeram-no a tal peso e delicadeza que agora se tornou um favorito no mundo musical. (...) O som do oboé puro aproxima-se muito da voz humana no agudo, mas no grave ele ainda tem muito do ruído de um ganso. ${ }^{150}$

As descrições tocantes às outras madeiras contêm informações mais interessantes no que diz respeito ao assunto dessa tese. Schubart segue falando da clarineta:

Seu caráter é um sentimento romântico e um som profundo de corações sensíveis. Quem toca a clarineta como Rheineck parece fazer uma declaração de amor a toda a raça humana. A extensão do instrumento não é grande, mas seja o que for que caia em sua esfera, ela o expressa com graça indescritível. O som é tão doce, tão lânguido, e quem quer que seja capaz de expressar os sons intermediários pode estar certo de sua vitória sobre os corações. (DUBOIS, 1983, p. 375, tradução nossa) (151 $^{15}$

A opinião de Schubart sobre a clarineta traduz muito bem a visão através da qual a mesma era contemplada por muitos na época em que o Ideen foi escrito. $\mathrm{Na}$ segunda metade do século XVIII, as associações do instrumento com o amoroso passaram a ser muito comuns e persistiram nos períodos seguintes.

Ao escrever sobre as flautas, Schubart dedica um parágrafo à flauta doce, ainda que essa já não fosse, à época, popular como nos anos anteriores (fato esse, aliás, mencionado no texto):

O som [da flauta doce] é extremamente suave e melancólico. Sua extensão dificilmente abrange duas oitavas. Essa flauta permite apenas um acompanhamento muito moderado e, devido a sua natureza, só pode ser usada para música de lamento e serenatas ou música noturna. O som

\footnotetext{
150 “(...) it has been used in all types of music, and first-rated geniuses have brought it to such height and delicacy that it has now become a favorite of the musical world. (...) The tone of the pure oboe very much approaches the human voice in the high [range], but in the low [range] it still has much of the honking of a goose."

151 "Its character is a romantic feeling and a thorough sound of sensitive hearts. Whoever plays the clarinet as Rheineke seems to make a declaration of love to the whole human race. The range of the instrument is not great, but whatever lies in its sphere, it expresses with indescribable grace. The sound is so sweet, so languishing, and whoever is able to express the intermediate tones thereon may be certain of his victory over the hearts."
} 
sempre muito suave e a pequena extensão do instrumento trouxeram-no hoje para perto do desuso; não é mais possível ouvi-lo nem na igreja nem em concertos. (DUBOIS, 1983, p. 377, tradução nossa) $)^{152}$

A descrição de Schubart sobre o uso do instrumento corresponde àquele citado por Weigel, no que diz respeito às serenatas. Além disso, a associação da flauta doce à lamentação também era algo comum na trajetória do instrumento pelos séculos XVII e XVIII, como será visto mais adiante.

Descrevendo a flauta transversal, o autor discorre sobre origens míticas e menções antigas do instrumento, citando a história de Apolo e Mársias (o que denota certa confusão sobre o instrumento, que é muito provavelmente posto no lugar do aulos grego). De qualquer modo, Schubart descreve o caráter do som do instrumento e, diferentemente do que relata em relação aos outros sopros de madeira, deixa claras algumas de suas associações alegóricas (DUBOIS, 1983, p. 379-80, tradução nossa): “O som dessa flauta é denso, cheio e puro, repleto de ternura e graça. A natureza rústica e intacta, o sentimento pastoral arcádico, ou seja, a écloga e o idílio musicais pertencem à flauta." 153

É curioso pensar que à época de Schubart, com o desuso da flauta doce, a flauta transversal possa ter passado a ser usada alegoricamente por terrenos antes mais comuns ao domínio da primeira.

O fagote recebe comentários elogiosos do autor:

\begin{abstract}
Esse instrumento desempenha um grande papel nos dias de hoje. Não só tem sido usado para o acompanhamento das mais importantes peças de órgão, do teatro, e de câmara, mas também foi elevado a solista agora que tem o mais claro [registro de] tenor; ele é absorvido nas extremas profundezas e tem um som como que divertido, satírico, então ele novamente se eleva ao fá do tenor [fá2], e através da arte ainda mais ao fá agudo do tenor [fá3], e ainda brilha no registro agudo tanto quanto no grave (...) O som do instrumento é tão sociável, tão charmosamente loquaz, que para cada alma intocada o último dia do mundo pode certamente acontecer entre muitos milhares de fagotes. $O$ fagote se adapta a todas as formas: ele acompanha música de guerra com máscula dignidade; é ouvido em lugares sacros com majestade; carrega a ópera [por virtude de sua função de baixo-
\end{abstract}

152 "The tone is extremely soft and melancholic. Its compass cromprises hardly two octaves. This flute permits only a very subdued accompaniment and, because of its nature, can only be used for mourning music and serenades or night-music. The all-too-soft tone and the narrow range of the instrument has brought it today nearly out of fashion; one hears it neither in the church nor at concerts any longer."

153 "The sound of this flute is thick, full and pure, [and] full of tenderness and grace. Rustic untainted nature, arcadian shepherd feeling, in a word, the musical ecologue and idyll appertain to the flute." 
contínuo]; raciocina com sabedoria no concerto; dá equilíbrio à dança; e é tudo aquilo que quiser ser. (DUBOIS, 1983, p.382-384, tradução nossa) ${ }^{154}$

Schubart apresenta o fagote como extremamente versátil, capaz das mais diversas expressões e também, consequentemente, de muitas representações.

Os textos de Schubart mostram uma visão alemã dos instrumentos em fins do século XVIII. A sua comparação com os textos de Mattheson e os poemas presentes nas gravuras de Weigel é interessante por permitir o apontamento de semelhanças e diferenças que ajudam a traçar, assim como os citados excertos de documentos franceses em relação à própria França, um panorama do modo como os instrumentos de sopro de madeira eram contemplados do ponto de vista de seu caráter e possibilidades alegóricas na Alemanha ao longo do período, clarificando ideias mantidas por tradição e outras que se transformaram com o passar do tempo.

154 "This instrument has played a great role in our days. Not only has it been used for the accompaniment of the most important pieces on the organ, the theater, and chamber, but also so raised [it] to solo playing that now the bassoon has the clearest tenor; it becomes absorbed in the extreme depths and has a somewhat amusing, mocking sound, then it again rises to tenor $F$ [ $f$ ], and through art still further to the high tenor $F\left[f^{\prime}\right]$ and also sparkles in the upper register as it has sparkled in the low register. (...) The tone of the instrument is so sociable, so charmingly talkative, that for every untainted soul the last day of the world may certainly run across many thousand bassoons. The bassoon adapts itself to all forms: it accompanies war music with manly dignity; it is heard in sacred rooms with majesty; [it] carries the opera [by virtue of its basso continuo function]; [it] reasons with wisdom at the concerto; [it] gives sway to dance; and [it] is everything it wants to be." 


\subsection{A flauta doce}

O século XVIII é um período de declínio para a flauta doce. Diferentemente das outras madeiras, que acabariam por ter um local reservado no naipe de sopros dos grupos orquestrais que começaram a se padronizar na segunda metade do século, culminando na formação mais comum da orquestra clássica, a flauta doce iria ser cada vez menos utilizada até cair em desuso no período seguinte a 1750 . Como explica Aguilar (2017, p.109):

A partir da segunda metade do século XVIII, vários fatores levaram a flauta doce a um progressivo declínio na música de concerto europeia. É unânime entre os autores a constatação de que ela foi sendo substituída pela flauta transversal.

De fato, o declínio do instrumento está ligado à grande popularização do uso da flauta transversal nos conjuntos instrumentais, provavelmente por se mostrar mais flexível que a flauta doce em aspectos como variação de dinâmica e projeção do som segundo os padrões exigidos pela nova música da época. De qualquer forma, a flauta doce voltaria a ser efetivamente utilizada apenas no século $X X$, quando ganharia destaque em meio ao revival da música antiga, além de um repertório contemporâneo original.

A decadência envolvendo o instrumento, que ocorre ao longo da primeira metade do século XVIII, é bem exemplificada pela gradativa diminuição de sua utilização, não tendo relação, no entanto, com a qualidade do repertório para ele composto durante o período (de fato, a flauta doce foi contemplada com obras de alguns dos maiores compositores da época, entre os quais Vivaldi, Telemann, Handel e Bach). Simpson afirma que

\footnotetext{
durante o período abrangendo aproximadamente as carreiras de Lully (1632-87) e Handel (1685-1759), a flauta doce foi com frequência especificada para uso orquestral. Seu uso estendeu-se, com belo e eficaz efeito, em numerosas passagens obbligato encontradas em obras sacras e seculares de grande escala. (1995, p. 92, tradução nossa) $)^{155}$
}

155 "During a period spanned approximately by the careers of Lully (1632-87) and Handel (1685-1759), the recorder was often specified for the orchestral use. It was also deployed, to beautiful and telling effect, in numerous obbligato passages found in large-scale sacred and secular vocal works." 
De qualquer modo, os outros sopros de madeira têm o século XVIII como um fértil período de popularização e desenvolvimento, enquanto que para a flauta doce parece ocorrer o contrário. Pode-se pensar o "período áureo" do instrumento como sendo, na verdade, os século XVI e XVII.

O uso de um instrumento musical com finalidade alegórica pode ser aplicável, compreensível e detectável em praticamente todos os gêneros musicais existentes ao longo dos períodos nos quais esta tese se concentra, embora seja abundantemente mais presente na música vocal ou cênica. Ora, a simbologia carregada por um instrumento pode ser eficiente em composições puramente instrumentais e livres de conexões específicas com um texto ou programa como, por exemplo, uma "sonata pastoral" ou ainda uma "sinfonia de guerra". No entanto, em obras vocais como cantatas, oratórios e óperas, a utilização alegórica de um instrumento é também extremamente rica e efetiva, complementando cenas e ambientações e intensificando as potencialidades de um texto. Não à toa, a maioria dos exemplos do uso instrumental alegórico é proveniente de obras desse tipo.

O uso alegórico da flauta doce é interessante por desdobrar-se em diversas facetas, ainda que algumas sejam tradicionalmente mais recorrentes. Simpson explana que

\begin{abstract}
de acordo com convenções que tinham crescido no teatro renascentista, e que continuaram a ser observadas por compositores tão diferentes como Purcell, Bach e Handel, flautas doces foram consideradas particularmente apropriadas para música acompanhando funerais, ou associadas de alguma forma com a dor. Como extensão disso, elas foram também frequentemente encontradas em música descrevendo eventos extraterrenos ou sobrenaturais. Outros usos comuns eram em cenas pastorais, em passagens expressando amor ou outras emoções ternas, para a imitação de canto de pássaros e para óbvio efeito ilustrativo quando compositores usavam textos que faziam referência a instrumentos de sopro de madeira. (1995, p. 93, tradução nossa) $)^{156}$
\end{abstract}

\footnotetext{
156 "According to conventions that had grown up in the renaissance theatre, and that continued to be observed by composers as different as Purcell, Bach and Handel, recorders were considered particularly appropriate for music accompanying funerals, or associated in some way with sorrow. As an extention of this, they were also found frequently in music depicting otherworldly or supernatural events. Other common uses were in pastoral scenes, in passages expressing love or other tender emotions, for the imitation of birdsong, and for obvious illustrative effect when composers set texts referring to woodwind instruments."
} 
A utilização do instrumento como alegoria do pastoral é uma das mais comuns, estabelecida, como visto, desde o medievo e alcançando notavelmente o século XVIII. Durante o século XVII esse uso ganha força devido à "expulsão" de grande parte dos instrumentos de palheta-dupla, anteriormente usados com frequência na representação pastoril, da nova música expressiva do período, especialmente da ópera. Weaver explica esse fenômeno dizendo que

talvez a transição das palhetas para as flautas doces tenha sido possível devido à redução da orquestra de ópera para instrumentos de corda somados, para fins programáticos, a poucos instrumentos de metal e flautas doces; assim, dispensadas do dever geral e na falta de instrumentos de palhetas, elas puderam assumir a identidade específica de instrumentos pastorais. (1961, p. 370, tradução nossa) $)^{157}$

Um dos grandes compositores desse período, Monteverdi também fez uso do instrumento por esse viés:

Quando Claudio Monteverdi compôs a música para L'Orfeo, uma nova ópera a ser apresentada na corte de Mântua como parte das celebrações do Carnaval de 1607, ele utilizou em torno de quarenta e cinco instrumentos diferentes. Muitos apareciam apenas brevemente, para adicionar cor a números específicos. Típico desses era a flauta doce sopranino que, com cordas, alaúde, cravo e harpa, dava um som cintilante ao coro pastoral do Ato I, "Lasciate i monti”. (SIMPSON, 1995, p.91, tradução nossa) ${ }^{158}$

De fato, o instrumento aparece na já mostrada lista do Orfeo como Un Flautino alla Vigesima Seconda.

O uso que Lully faz das madeiras em sua obra é significativo não só por ser historicamente o primeiro dentro de um contexto mais verdadeiramente orquestral, mas também, entre outros motivos, por certificar o papel dos instrumentos como alegoria.

\footnotetext{
157 "Perhaps the transiton from reeds to recorders was made possible by the reduction of the operatic orchestra to stringed instruments augmented for programmatic purposes by a few brass instruments and recorders; thus relieved of general duty and in absence of reed instruments, the recorders could take on the specific identity of pastoral instruments."

158 "When Claudio Monteverdi composed the music for Orfeo, a new opera to be presented at the Mantuan court as part of the 1607 Carnival celebrations, hem ad use of some forty-five different instruments. Many appeared only briefly, to add colour to a particular number. Typical of these was the sopranino recorder that, with strings, lutes, harpsichord and harp, imparted a glittering sound to the Act I pastoral chorus 'Lasciate i monti'."
} 


\title{
No que concerne a flauta doce, Rowland-Jones explica que
}

\begin{abstract}
Lully quase sempre reserva para ocasiões especiais instrumentos que não os de cordas friccionadas [arcos] ou dedilhadas e de madeiras de palhetadupla. A interpolação de trompetes ou flautas doces no timbre orquestral e vocal mais comum por si só causa um frisson de entusiasmo. Lully usa flautas doces em não menos do que 60 ocasiões, sempre efetivas, apesar de muitas serem bastante breves. Elas espalham-se por 17 ballets, mascaradas e divertissements, cinco comédies-ballets (principalmente com Molière), e todas com exceção de uma, Roland, de suas 14 tragédies en musique completas - essas, no entanto, incluem metade do número total de ocasiões. No processo, ele emprega muito da exclusivamente ampla variedade de associações e simbolismos da flauta doce. (2009, p. 217, tradução nossa) ${ }^{159}$
\end{abstract}

De forma detalhada, o autor lista nada menos do que treze categorias alegóricas representadas pelas flautas doces em trinta e quatro obras de diversos gêneros nas quais Lully utiliza o instrumento, explicando cada uma delas:

\begin{abstract}
'Pastoral' cobre toda a vida de pastores, mas principalmente a Árcade. 'Sensualidade' (...) significa prazer sensual, mais do que luxúria. 'Amor' inclui casamento. 'Água' é geralmente água corrente. 'Pássaros' significa seu canto. 'Mágica' cobre o sobrenatural, geralmente. 'Deuses' são deidades clássicas maiores ou menores, com referência especial ao deus pastoral Pan. 'Sacrifícios' são ocasiões ritualísticas, exceto a 'Morte', que inclui ritos fúnebres. O deus Mercúrio e as Musas (principalmente Euterpe), têm categorias próprias. 'Conflito' inclui tanto guerra como discussão." (2009, p. 220 , tradução nossa) ${ }^{160}$
\end{abstract}

A amplitude alegórica do instrumento para Lully é notável, mas as diferentes representações não aparecem em quantidade semelhante nas obras, sendo que as associações ao Pastoral, ao Amor e aos Deuses são as mais numerosas.

\footnotetext{
159 "Lully almost always reserves for special occasions instruments other than bowed and plucked strings and double-reed woodwinds. The interpolation of trumpets or recorders into the ongoing orchestral and vocal timbre in itself causes a frisson of excitement. Lully uses recorders on no less than 60 occasions, always effective, although many are quite brief. They are spread across 17 ballets, mascarades and divertissements, five comédies-ballets (mainly with Molière), and all but one, Roland, of his $14 \mathrm{com}$ pleted tragédies en musique - these latter, however, include half the total number of occasions. In the process, he employs most of the recorder's uniquely wide range of associations and symbolisms." 160 "'Pastoral' covers all shepherd life, but mainly Arcadian. 'Sensuality' (...) means sensual pleasure, more than lust. 'Love' includes marriage. 'Water' is generally flowing water. 'Birds' means birdsong. 'Magic' covers the supernatural generally. 'Gods' are major and minor classical deities, with special reference to the pastoral god Pan. 'Sacrifices' are ritual occasions, except that 'Death' includes funeral rites. The god Mercury, and the Muses (particularly Euterpe), have columns of their own. 'Conflict' includes both warfare and quarrelling."
} 
Rowland-Jones afirma ainda que há outras representações alegóricas da flauta doce que não são utilizadas por Lully, como o voo da alma ou de pássaros, anjos, ou o ar, entre outras. O autor segue com descrições detalhadas das associações simbólicas do instrumento:

Pastores sempre foram associados a instrumentos de sopro, tanto a flautas longitudinais como a gaitas-de-fole (para as quais Lully usava musettes). Pastores faziam e tocavam esses instrumentos para passar o tempo, para assegurar o rebanho de sua presença, e porque acreditava-se que tocar instrumentos feitos a partir de ossos das ovelhas reanimava suas almas. Poesia e drama pastoral Árcade baseiam-se nos amores confusos de pastores e pastoras; o formato da flauta doce a associava à luxúria e prazer sensual, mas os amores dos pastores Árcades são inocentes, e Lully raramente usa flautas doces para representar as tentações do desejo sensual. Associações com água corrente, sono e cantos de pássaros vêm dos sons suaves das flûtes douces, e dos textos e enredos da poesia pastoral. Isso também é válido em relação aos simbolismos sobrenaturais da flauta doce - mágica e a intervenção dos deuses permeiam os enredos das óperas e ballets de Lully. (2009, p. 243, tradução nossa) $)^{161}$

Uma das mais importantes e duradouras associações alegóricas referentes à flauta doce, associação essa que figurará fortemente no século XVIII, é aquela relativa ao fúnebre. Rowland-Jones explana que

o simbolismo sobrenatural da flauta doce (...), particularmente seu uso em cenas de morte e funeral, deriva principalmente do som solene e extraterreno do consort de flautas. Há também uma ligação importante, (...) com a presença de instrumentos de sopro em sacrifícios aos deuses gregos e romanos, especialmente em funerais. De fato, (...) a maioria do simbolismo da flauta doce usado por Lully tem antecedentes clássicos; ele se utilizou das Metamorfoses de Ovídio e das Éclogas de Virgílio, em especial. Flûtes douces criaram um "som Helênico" na descida das musas em La Mort d'Adonis de Perrin e Boesset em 1659, como haviam feito na Pastorale d'Issy de Perrin/Cambert anteriormente naquele ano. A era dourada das primeiras décadas do reino de Luis XIV era vista pelo próprio rei, o novo Apolo, e por seus arquitetos, paisagistas, dramaturgos, artistas e músicos, como a reencarnação da glória de Roma. O uso da flauta doce por Lully para representar instrumentos de sopro clássicos pode ter sido estimulado por

161 "shepherds have always been associated with pipes, either end-blown duct-flutes or bagpipes (for which Lully uses musettes). Shepherds made and played pipes to while away time, to reassure the flock of their presence, and because it was believed that playing an instrument fashioned from the bones of a sheep reanimated its soul. Arcadian pastoral poetry and drama is based upon the confused loves of shepherds and shepherdesses; the recorder's shape associated it with lust and sensual pleasure, but the loves of Arcadian shepherds are innocent, and Lully rarely uses recorders to represent the temptations of sensual desire. Associations with running water, sleep and birdsong arise from the soft sounds of flûtes douces, and from the texts and plots of pastoral poetry. This is also true of the recorder's supernatural symbolisms - magic and the intervention of gods permeate the plots of Lully's ballets and operas." 
seus suntuosos arredores, onde ele podia ver pinturas de Poussin, Claude e outros, que seguiam a tradição clássica. (2009, p. 243-244, tradução nossa) $)^{162}$

Segundo o autor, o uso alegórico da flauta doce por Lully não teria sido uma novidade, já que as concepções do compositor estavam baseadas em aspectos há muito tempo consolidados: "A partir de 1658 ele usou flautas doces em seus próprios ballets da mesma forma que haviam sido utilizadas no meio século precedente." (2009, p.244). Entretanto, o compositor também mereceria créditos por inovações, uma vez que "foi a própria imaginação de Lully que resultou em seu uso das flautas doces em cenas de sono." (2009, p.245).

Rowland-Jones faz também um comentário importante a respeito da possível relevância de Lully na questão envolvendo a reconstrução dos instrumentos antigos. 0 autor descreve a oitava Entrée do Ballet de la Raillerie, de 1659, onde

duas vozes masculinas, dois violinos e duas flautas doces, usando alternadamente as mesmas duas linhas musicais, criam Echos em pares (na forma de uma sarabanda canônica), contrastando, em "differente harmonie", amor cortês e amor Árcade. (2009, p. 221, tradução nossa) $)^{163}$

Segundo ele, essa experiência composicional teria convencido o compositor de que

os sons assertivos das flautas doces em estilo antigo do fim do Renascimento ou das transicionais não combinavam nem com a sonoridade de seus violinos nem com as sutilezas do estilo de canto francês, e assim fizeram-no encorajar os Hotteterre e outros a redesenhar o instrumento. Seu sucesso na produção de um novo estilo de flauta doce refinado e

162 "The recorder's supernatural symbolism, however, particularly its use in death and funeral scenes, stems mainly from the solemn, otherworldly sound of a recorder consort. There is also an important link with the presence of pipes in Greek and Roman sacrifices to the gods especially at funerals. In fact, most of Lully's recorder symbolisms have classical antecedents; he drew on Ovid's Metamorphoses and Virgil's Eclogues in particular. Flûtes douces were said to create a 'Hellenic sound' for the descent of the Muses in Perrin and Boesset's La Mort d'Adonis in 1659, as they had in the Perrin/Cambert Pastorale $d^{\prime}$ Issy earlier in the same year. The Golden Age of the earlier decades of Louis XIV's reign was seen by the king himself, the new Apollo, and by his architects, landscape designers, dramatists, artists and musicians, as a reincarnation of the glory of Rome. Lully's use of the recorder to represent classical pipes may have been stimulated by his sumptuous surroundings, where he would have seen paintings by Poussin, Claude and others in the classical tradition."

163 "Two male voices, two violins and two recorders, using in turn the same two lines in music, create Echos in pairs (in a canonic sarabande form) contrasting, in 'differente harmonie', courtly love and Arcadian love." 
expressivo pode ter levado Lully a explorar as qualidades do instrumento mais frequentemente e numa gama mais ampla de contextos associativos. (2009, p. 238, tradução nossa) $)^{164}$

Outra figura representativa no uso simbólico dos instrumentos, Marc-Antoine Charpentier insere-se nos mesmos contextos musicais de Lully. Simpson afirma que Charpentier "tinha um excelente ouvido para colorido orquestral", frequentemente utilizando seus instrumentos em combinações contrastantes, e que "flautas doces são especificadas em muitas de suas partituras operísticas, obras dramáticas e religiosas." (1995, p. 92, tradução nossa). Sobre os aspectos simbólicos, a autora afirma que

em seus motetos de Natal, [as flautas doces] são usadas para enfatizar os aspectos pastorais da história da natividade. Sua ópera pastoral Actéon (1683-5) utiliza o instrumento num contexto similar. Outras passagens dignas de nota são o delicadamente cromático Prelúdio do Ato IV de sua ópera dramática Medée (1693), e o De Profundis que ele escreveu para marcar a morte da Rainha Maria Teresa (30 de Julho de 1683), que contém um maravilhoso solo de baixo com duas flautas doces obbligati, 'A Custodia matutina...' ('Israel espera pela vinda do Senhor assim como uma sentinela espera pela manhã'). ${ }^{165}$

Vê-se, nos exemplos da autora, as simbologias pastoral e fúnebre.

Duron (1986, p. 51) afirma que na música de Charpentier os instrumentos de sopro são simbolicamente utilizados em contraste com as cordas, como "efeitos especiais" e comenta a respeito do uso do trio de duas flautas doces e baixo continuo que o compositor costuma empregar:

Essa formação parece ser usada para pintar os sentimentos mais doces: o amor certo, não aquele dos risos e prazeres (confiado mais voluntariamente às flautas transversais), mas aquele da ternura, da calma; em Feste de Ruel, após um longo récit, quando Tircis ousa pela primeira vez confessar seu amor por Iris, as flautas doces intervêm (...) Segue um interessante diálogo;

\footnotetext{
164 "the assertive sounds of old-style late Renaissance or transitional recorders matched neither the tone-qualities of his violins nor the subtleties of French singing style, and therefore caused him to encourage the Hotteterres and others to redesign the instrument. Their success in producing a refined and expressive new style of recorder may have led Lully to exploit the recorder's qualities more frequently and in a wider range of associative contexts."

165 "In his Christmas motets, they are used to emphasise the pastoral aspects of the nativity story. His pastoral opera Actéon (1683-5) features recorders in a similar contecontextoer passages worth noting are the delicately chromatic prelude to Act IV of his dramatic opera Medée (1693), and the De Profundis he wrote to mark the death of Queen Marie-Thérèse (30 July 1683), which contains a wonderful bass solo with two obbligato recorders, 'A custodia matutina...' ('Israel hopes for the coming of the Lord as a watchman does for the morning')."
} 
Iris responde (...) e canta a beleza da natureza: as flautas se calam. Em contrapartida, todas as intervenções de Tircis apaixonado, declarando sua paixão, são acompanhadas pelas flautas doces. (1986, p. 54, tradução nossa) $)^{166}$

O autor comenta também sobre a possibilidade das flautas doces como alegoria para a evocação da noite, como o Dialogo inter Angelos et Pastores seria testemunha, ainda que essa representação não fosse exclusiva desses instrumentos. Duron dá ainda outros interessantes exemplos de seu uso alegórico por Charpentier na ópera Médée:

[No Ato I] Jason se dirige a Médée; as flautas sustentando o verso 'Como eu seria feliz se fosse menos amado!' simbolizam então o amor feliz, o êxito do amor Jason-Créuse. As flautas desaparecem da palavra 'glória', que significa evidentemente para Jason o fim de seu amor, a partida de Créuse com Oronte, seu retorno aos braços de Medée; o sentimento aqui descrito não é de forma alguma agradável!

[No Ato 2 ocorre] o divertissement que Oronte oferece para provar seu amor por Créuse (a amante de Jason, a rival de Médée, portanto). A instrumentação é muito significativa: o Amor deveria cantar acompanhado pelas flautas; (...) o trio de flautas (fl.l/fl.Il/flauta baixo) toca apenas nos ritornelos descritivos durante os quais o Amor tenta seduzir Créuse. E, justamente, ela resiste, o amor (aquele de Oronte, evidentemente) não pode seduzí-la! A ausência das flautas na ária do Amor não é então fortuita. [No Ato III], ao final da cena I, um trio de violinos (vl.I/vl.Il/b.c.) acompanha um diálogo fogoso em que Médée e Oronte juram se vingar dos "amantes pérfidos". Mas logo quando Médée percebe Jason, seu coração se comove e as flautas aparecem para sublinhar sua fraqueza e a entrada de Jason.

[No Ato IV] Médée aceita fugir mas exige anteriormente o casamento de Créuse e Oronte; Créon não tolera tal exigência. Médée em desespero é forçada a usar seus poderes: Créon havia ordenado a seus soldados que a agarrassem, mas estes se voltaram contra ele. O medo de Créon é suficiente, Médée decide acalmar os combatentes e para retomar a calma, o alívio, faz intervirem os 'espíritos amáveis'. Um 'Prélude tendre' confiado a um trio de flautas (fl.I/fl.Il/b.c.) ilustra a metamorfose da violência em calma. (1986, p. 55-57, tradução nossa) ${ }^{167}$

166 “Cette formation semble utilisé pour peindre des sentiments plus doux: l'amour certes, non pas celui des ris et des plaisirs (confié plus volontiers aux flûtes allemandes), mais celui de la tendresse, du calme; dans la Feste de Ruel, après un long récit, lorsque Tirsis ose pour la première fois avouer son amour pour Iris, les flûtes douces interviennent (...) Suit un intéressant dialogue; Iris répond (...) et chante la beauté de la nature: les flûtes se taisent. En revanche, toutes les interventions de Tirsis amoureux, déclarant sa flamme sont accompagnées par les flûtes à bec."

167 “Jason s'adresse ici à Médée; les flûtes soutenant le vers $\ll$ Que je serois heureux si j'étois moins aymé!> symbolisent donc l'amour heureux, la réussite de l'amour Jason - Créuse. Les flûtes s'estompent dès le mot $<<$ gloire $>>$, qui signifie évidemment pour Jason la fin de son amour, le départ de Créuse avec Oronte, son retour dans les bras de Médée; le sentiment décrit ici n'est plus du tout agréable!

(...) le divertissement qu'o ffre Oronte pour prouver l'amour qu'il porte à Créuse (l'amante de Jason, la rivale de Médée donc). L'instrumentation est très ignificative: I'Amour devrait chanter accompagné par les flûtes; (...) le trio de flûtes (fl.l/fl.Il/basse de flûte) ne joue que les ritournelles descriptives durant 


\title{
Duron complementa as informações anteriores dizendo que
}

\begin{abstract}
esta última intervenção é ligada à calma da noite, evocada ao máximo. Uma só vez em toda a obra de Charpentier, o senso de intervenção das flautas nos escapa. Isso ocorre, no Prólogo, na ária de Bellone (deusa da Guerra) (...). A Vitória, a Glória e Bellone rivalizam para afirmar o poder de Luis XIV: ninguém sonha em triunfar sobre esse rei, a prolongar a guerra; Luis XIV combate a fim de abafá-la e 'trazer calma à terra' (estamos em 1694, no meio da guerra da Liga de Augsburgo). As flautas doces são então associadas às palavras muito vingativas de Bellone talvez porque a Vitória está mais ou menos ligada à noção de paz. (1986, p. 57, tradução nossa) $)^{168}$
\end{abstract}

A maioria dos exemplos dados por Duron mostram claramente a flauta doce como alegoria do amor. De fato, como confirma Lasocki (2001), as associações do instrumento com o amor são as mais constantes.

A música inglesa do fim do século XVII, fortemente influenciada pelo gosto francês da época, também utilizou-se dos instrumentos alegoricamente. O compositor Purcell traz exemplos interessantes desse aspecto. Em sua ode Hail! Bright Cecilia, de 1692, ele utiliza a flauta doce de forma claramente alegórica. Em um dos movimentos da obra, In vain the Am'rous flute, Purcell escreve para um par do instrumento a fim de ilustrar musicalmente o conteúdo do texto, o que parece óbvio. No entanto, os versos de Nicholas Brady relatam o modo como o instrumento era visto a partir de seus símbolos:

lesquelles l'Amour tente de séduire Créuse. Et justement, elle résiste, l'amour (celui d'Oronte évidemment) ne peut la séduire! L'absence des flûtes dans l'air de l'Amour n'est donc pas fortuit.

(...) A la fin de la scène 1, un trio de violons (vl.I/vl.II/b.c.) accompagne un dialogue fougueux où Médée et Oronte se jurent bien de se venger contre les <<perfides amans»>. Mais dès que Médée aperçoit Jason, son coeur s'émeut et les flûtes apparaissent pour souligner sa faiblesse et l'entrée de Jason.

(...) Médée accepte de fuir mais exige auparavant le mariage de Créuse et Oronte; Créon ne tolère pas une telle exigence. Médée au désespoir est contrainte d'user de ses pouvoirs: Créon avait ordonné à ses soldats de se saisir d'elle, mais ils se retournent contre lui. La frayeur de Créon est suffisante, Médée decide d'apaiser les combattants et pour retrouver le calme, l'apaisement, fait intervenir des <<Fantômes aimables〉>. Un <<Prélude tendre>> confié à un trio de flûtes (fl.l/fl.Il/b.c.) illustre la métamorphose de la violence en calme."

168 "Cette dernière intervention est à mettre en liaison avec le calme de la nuit, évoqué plus haut. Une seule fois dans toute l'oeuvre de Charpentier, le sens de l'intervention des flûtes nous échappe. II s'agit, dans le Prologue, de l'air de Bellone (déesse de la Guerre) (...). La Victoire, la Gloire et Bellone rivalisent pour affirmer la puissance de Louis XIV: plus personne ne songe à triompher de ce roi, à prolonger la guerre; Louis XIV combat pour étouffer la guerre et <<rendre le calme à la terre>> (nous sommes en 1694 au milieu de la guerre de la Ligue d'Augsbourg). Les flûtes à bec sont donc associées aux paroles très vindicatives de Bellone peut-être parce que la Victoire est liée plus ou moins à la notion de paix." 
Em vão a flauta amorosa e a guitarra suave Juntamente trabalham para inspirar

Calor bruto e desejo vago, Enquanto vossas árias castas gentilmente movem Flamas seráficas e Amor celestial. ${ }^{169}$

Como recorrente em textos exaltando Santa Cecília, a padroeira dos músicos na tradição Católica, o órgão, instrumento associado à santa, é elevado em meio aos outros instrumentos musicais, como o maior de todos, único digno da real conexão com o divino. Desse modo, no decorrer de seu poema, Brady afirma que, por mais que se esforce, nenhum outro instrumento é capaz de proporcionar à alma humana elevação semelhante à conseguida pelo órgão (chamado de "máquina maravilhosa" [wond'rous machine] pelo autor). A flauta doce é então representada como um instrumento delicado e amoroso, que talvez inspire paixões mais carnais do que espirituais. De qualquer forma, a conexão com o amor é evidente. Além disso, a flauta transversal barroca ainda não se popularizara na Inglaterra de Purcell, sendo que o compositor provavelmente nunca escreveu para o instrumento, o que garante que suas flautas sejam realmente flautas doces, como afirma Holman (1996, p. 21, tradução nossa): “A flauta transversal [barroca, do modelo francês] parece ter chegado mais tarde [na Inglaterra] - por volta de 1700 - e nunca foi usada por Purcell."170

A associação dos sopros de madeira ao canto dos pássaros distingue-se entre as representações alegóricas por dar-se graças a fatores físicos, não necessariamente históricos ou abstratos como na maioria das outras. De fato, por questões relativas à semelhança de seus timbres àqueles dos sons das aves, grande parte desses instrumentos foram, e ainda são, requisitados para tal representação e as flautas doces talvez tenham sido os instrumentos mais utilizados para esse fim até o século XVIII. Os pequenos flageolets e as flautas doces menores, como a soprano e a sopranino, frequentemente exerceram esse papel, tanto na música vocal e cênica como na puramente instrumental.

\footnotetext{
169 "In vain the am'rous flute and soft guitar Jointly labour to inspire Wanton heat and loose desire, Whilst thy chaste airs do gently move Seraphic flames and haev'nly love." 170 "The transverse flute seems to have arrived later - around 1700 - and was never used by Purcell."
} 
Além de seu uso nesse contexto em diversas óperas e outras obras do gênero vocal, o repertório do instrumento dispõe de conhecidos e amplamente referenciados exemplos de publicações e música instrumental escritas nesse contexto, sendo o concerto intitulado // Gardelino, de Vivaldi, e a sonata de Williams "em imitação de pássaros", dois deles. É interessante citar também o The Bird Fancyer's Delight, publicado em Londres, por volta de 1715. Esse pequeno livro, escrito na intenção de mostrar melodias que poderiam ser ensinadas a diferentes espécies de pássaros, é direcionado a flageolets e às flautas doces mais agudas, soando na mesma altura do canto das aves, provando que o instrumento era também relacionado e utilizado junto aos animais de forma prática.

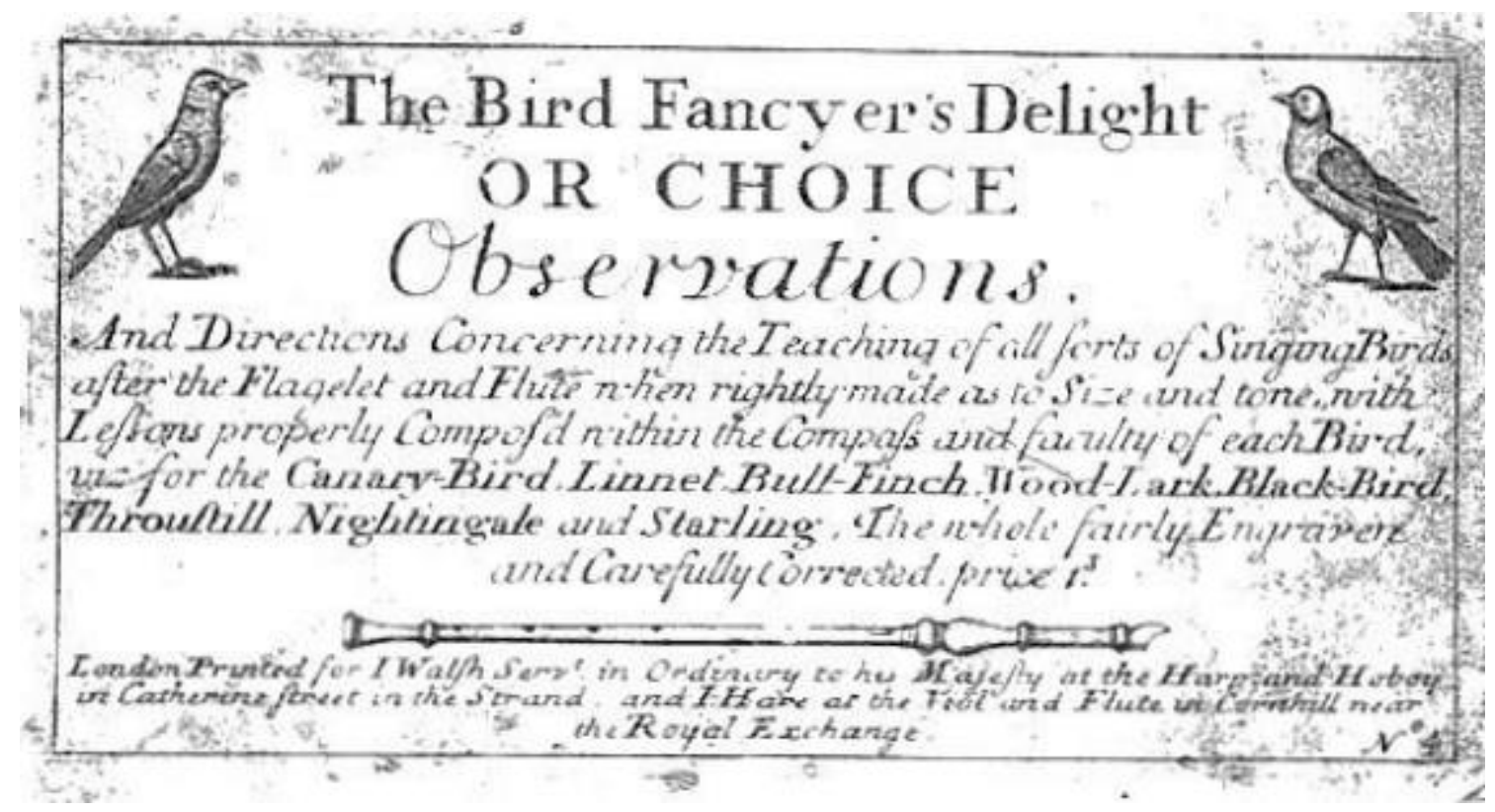

Fig. 38 - Frontispício do The Bird Fancyer's Delight (ca. 1715)

Dentre os compositores mais importante do alto Barroco, na primeira metade do século XVIII (que vem a ser a derradeira época da utilização da flauta doce no período), as figuras de Vivaldi e Telemann destacam-se em relação ao uso do instrumento em obras vocais (uso esse frequentemente alegórico) e em suítes, concertos e mais obras instrumentais. Handel compôs sonatas para a flauta doce e a utilizou em nada menos do que 90 movimentos de suas óperas, oratórios, cantatas e 
outras peças sacras, muitas vezes como veículo das tradicionais alegorias do pastoral e do amor (LASOCKI, 1998).

A obra de J.S. Bach, referencial em tantos aspectos concernentes ao bom fazermusical, é aqui também significativa, uma vez que seu uso alegórico dos instrumentos é exemplar em diversos momentos.

O compositor utilizou a flauta doce em obras vocais e algumas instrumentais. Como mostra Tarasov (2005?, tradução nossa), “a flauta doce é usada em por volta de um décimo das cantatas de Bach sobreviventes, contribuindo para cenários musicais muito comoventes e emocionais." O autor divide o uso do instrumento por Bach em três fases, sendo que "entre 1707 e 1717 o uso da flauta doce é restrito a cantatas sacras; no período seguinte (1717-1723), durante seu tempo em Köthen, ele usa a flauta doce em peças instrumentais. Mais tarde, em Leipzig (1723-1750), ele se foca novamente nas cantatas". Reforçando causas e efeitos desse uso, Tarasov afirma ainda que "no Barroco, as flautas doces eram consideradas para a concessão de um certo colorido sonoro e eram com frequência usadas em contexto alegórico." 171

Em meio a esses possíveis contextos, dois deles são aqui destacados, em obras importantes e bem conhecidas do compositor.

A cantata profana BWV 208, também chamada "Cantata da Caça", utiliza duas flautas doces em uma das árias pastorais mais famosas do compositor, na qual a personagem Pales (representante da divindade romana dos pastores e rebanhos) canta, enquanto acompanhada pelas flautas e o baixo continuo:

As ovelhas podem pastar sem perigo

Onde um bom pastor as observa.

Onde governantes bem governam, Podemos sentir paz e descanso

E o que faz os países felizes. ${ }^{172}$

\footnotetext{
171 "the recorder is used in about a tenth of Bach's surviving cantatas, contributing to very moving and emotional musical scenarios."; "between 1707 and 1717 the use of the recorder is restricted to church cantatas; in the following period $(1717-1723)$ during his time in Köthen he makes use of the recorder in instrumental works. Later in Leipzig $(1723-1750)$ he focuses again on cantatas."; "in the Baroque era recorders were considered to provide a certain sound colouring and were often used in an allegorical context."

172 "Schafe können sicher weiden,

Wo ein guter Hirte wacht.

Wo Regenten wohl regieren,
} 
As conexões do instrumento com o contexto pastoral ficam aqui muito claras, levando-se em consideração o conteúdo do texto e as características da personagem que o canta. O seu uso faz-se retoricamente muito efetivo, já que as flautas doces são usadas apenas nessa delicada ária durante a cantata, o que resulta num momento de sonoridade única ao longo de toda a obra.

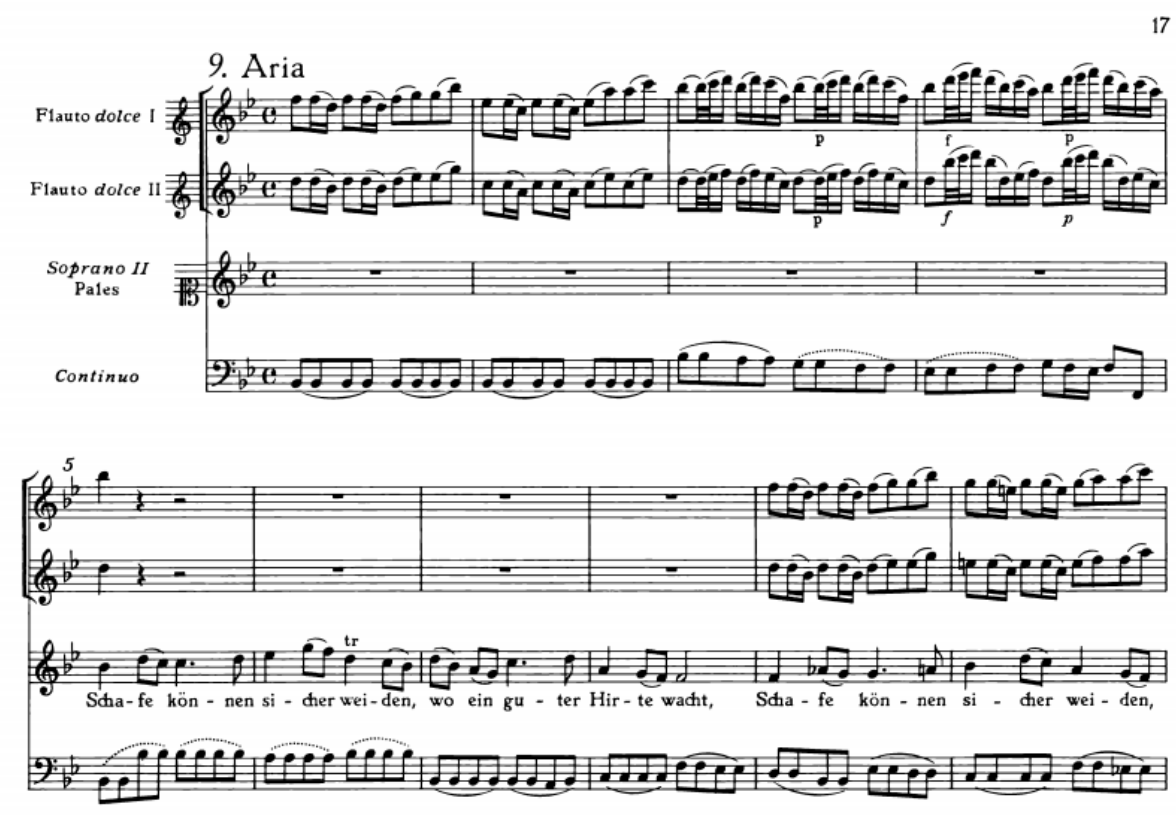

Fig. 39 - Início da ária de Pales, na Cantata BWV 208 de J.S. Bach (1713)

A cantata BWV 175 apresenta também fortes conotações pastorais, mostradas desde seu título: "Ele chama suas próprias ovelhas pelo nome". Diferentemente do exemplo anterior, essa é uma obra sacra. Portanto, a ideia do pastoral converte-se aqui naquela envolvendo a simbologia de Jesus como um pastor que tem em seus fiéis seu rebanho. Em sua obra, Bach utilizou a flauta doce como solista ou ainda em pares ou trios, como nessa cantata. Os três instrumentos são usados em conjunto em três dos sete movimentos da obra. A sonoridade pastoral é aplicada por Bach desde o primeiro movimento, quando as flautas acompanham um recitativo de tenor, com o texto "Ele chama suas próprias ovelhas pelo nome e as conduz". Em seguida, uma ária de alto também acompanhada pelo trio de flautas continua como uma prece das ovelhas ao pastor: 
Venha, conduza-me,

Minha alma anseia por verdes pastagens!

Meu coração suspira,

Geme dia e noite,

Meu pastor, minha alegria! $!^{173}$

O costumeiro coral que finaliza a obra ganha também uma sonoridade especialmente pastoral com a participação das flautas doces.

Em “O bebê recém-nascido", BWV 122, uma cantata natalina, Bach emprega o mesmo trio de flautas doces em apenas um recitativo. A temática do nascimento de Jesus Cristo era tradicionalmente conectada a questões pastorais, o que explica o uso dos instrumentos no momento em que um soprano canta:

$\mathrm{O}$ anjos que antes

Afastaram-se de vós como dos amaldiçoados

Enchem agora o ar com coros na alturas

Enquanto rejubilam sobre vossa salvação.

Como Deus do paraíso

Da companhia dos anjos vos privou

Ele agora na terra vos deixa

Tornarem-se perfeitamente abençoados por Sua presença

Agradeçam-no portanto agora com voz plena

No tempo esperado da nova aliança. ${ }^{174}$

O texto parece fazer referência ao momento da história na qual um coro de anjos aparece aos pastores na noite de Natal. Portanto, as flautas doces auxiliam na ambientação sonora.

\footnotetext{
173 “Komm, leite mich,

Es sehnet sich

Mein Geist auf grüner Weide!

Mein Herze schmacht,

Ächzt Tag und Nacht,

Mein Hirte, meine Freude."

174 "Die Engel, welche sich zuvor

Vor euch als vor Verfluchten scheuen,

Erfüllen nun die Luft im höhern Chor, Um über euer Heil sich zu erfreuen.

Gott, so euch aus dem Paradies

Aus englischer Gemeinschaft stieß,

Läßt euch nun wiederum auf Erden

Durch seine Gegenwart vollkommen selig werden:

So danket nun mit vollem Munde

Vor die gewünschte Zeit im neuen Bunde."
} 
A cantata BWV 46 utiliza um par de flautas doces como que conectando diferentes alegorias. Tarasov descreve a participação dos instrumentos:

No prelúdio, as duas flautas parafraseiam os suspiros do coro aflito; (...) então [há] brilhantes figuras alternadas no recitativo do tenor descrevendo a destruição de Jerusalém (mas com abrigo da tempestade). Elas são usadas para efeito pastoral na ária de alto. (2005?, tradução nossa) $)^{175}$

De fato, a cantata é dominada pelo afeto da dor, lamentação e culpa. Tradicionalmente, as flautas doces também se prestavam a essa representação. No entanto, a ária de alto na qual as flautas também figuram, talvez o momento mais sereno da cantata, traz com seu texto a ideia pastoral ao dizer que Jesus reúne os justos "como suas ovelhas". Dessa forma, Bach faz uso da flauta doce como detentora de diversos significados alegóricos, trazendo ao instrumento uma rica dubiedade simbólica que, ainda que complexa, é retoricamente inteligível.

A alegoria do fúnebre junto à flauta doce é muito presente em Bach, como se vê em diversas obras sacras.

Na cantata BWV 81, há um caminho temático que leva do desespero do abandono até a alegria da certeza da proteção divina. Duas flautas doces são usadas apenas no primeiro movimento, no auge, então, do discurso desesperançoso do fiel. Nessa ária de alto, o texto relata:

Jesus dorme, qual deveria ser minha esperança?

Não vejo eu

Com o rosto pálido

O abismo da morte já aberto? ${ }^{176}$

Após esse momento, as flautas não serão mais ouvidas e a possibilidade de esperança apresentada no decorrer do texto tem nova orquestração, somada à sonoridade calorosa e reconfortante de dois oboés d'amore.

\footnotetext{
175 "In the prelude, the two recorders paraphrase the sighs of the grieving choir; (...) then glowing alternating figures in the recitative for Tenor describing the destruction of Jerusalem (but resting for the storm). They are used to pastoral effect in the aria for Alto."

176 "Jesus schläft, was soll ich hoffen?

Seh ich nicht

Mit erblasstem Angesicht

Schon des Todes Abgrund offen?"
} 
O famoso Actus tragicus, BWV 106, com temática fúnebre, utiliza apenas cordas graves (com destaque para as violas da gamba) e duas flautas doces, além do baixo-continuo), para acompanhar coro e solistas. A ausência de violinos e outros instrumentos mais agudos dá destaque à sonoridade das flautas, tradicionalmente muito apropriadas para esse tipo de música.

Na cantata BWV 127, na qual a ideia do fúnebre também se destaca, Bach faz um uso deveras interessante das duas flautas doces, especialmente na ária de soprano. Juntamente com a voz, há um oboé claramente solista e as flautas recebem um papel simples de acompanhamento. No entanto, as colcheias constantes entoadas pelos instrumentos, apoiadas por pizzicati das cordas, dão à música um efeito solene e processional, que ambientam de forma catártica as palavras:

A alma descansa nas mãos de Jesus Apesar da terra cobrir esse corpo.

Ah, chamem-me depressa, sinos fúnebres

Eu não tenho medo de morrer

Uma vez que meu Jesus me acordará novamente. ${ }^{177}$

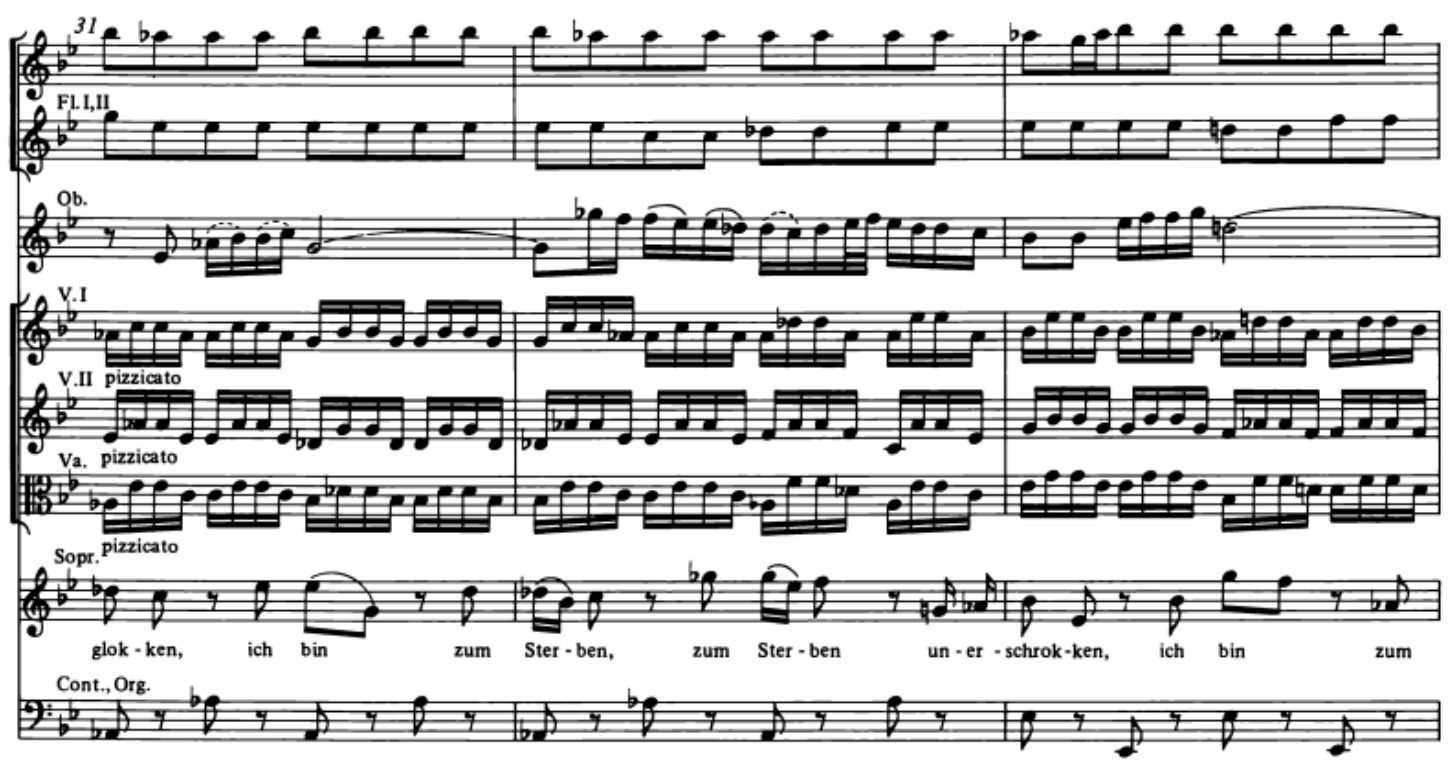

Fig. 40 - Excerto da parte B na ária de Soprano da Cantata BWV 127 de J.S. Bach (1725), no qual vê-se as partes de flautas doces (os dois primeiros pentagramas) em colcheias constantes em staccato, acompanhando junto das cordas os cantos do oboé e da voz solista

$-$

177 “Die Seele ruht in Jesu Händen,

Wenn Erde diesen Leib bedeckt.

Ach ruft mich bald, ihr Sterbeglocken,

Ich bin zum Sterben unerschrocken,

Weil mich mein Jesus wieder weckt." 
Não é incomum em Bach, bem como em outros compositores, encontrar-se determinado instrumento sendo usado em poucos momentos de uma obra, ou ainda em um único movimento. Nesses casos, a exclusividade desses momentos termina por destacá-los em meio ao todo. Quando usados de forma alegórica, o simbolismo envolvido também é destacado, consequentemente. Em relação à flauta doce, exemplos desse tipo podem ser vistos nas obras anteriormente citadas bem como em muitas outras, como é o caso de duas grandes peças vocais de Bach, o Oratório de Páscoa, BWV 249, e a Paixão segundo São Mateus, BWV 244.

Nas duas obras, o som do instrumento, também como alegoria do fúnebre, surge em apenas um breve momento. No orátorio, cuja música é dominada pela alegria e regozijo da ressurreição de Cristo, ouvem-se duas flautas doces na ária de tenor cujo texto, focado na ideia da morte, diz

Gentil deverá ser a dor da minha morte

Apenas um sono,

Jesus, através de seu véu.

Sim, ele irá ali me refrescar,

E as lágrimas de meu sofrimento

Limpará confortavelmente de meu rosto. ${ }^{178}$

$\mathrm{Na}$ extensa paixão, as flautas doces figuram apenas em um recitativo para tenor e coro, logo após a cena no Monte das Oliveiras, quando Jesus diz a seus discípulos, pouco antes de ser preso e levado a julgamento: "Minha alma está triste até a morte". A música segue o texto:

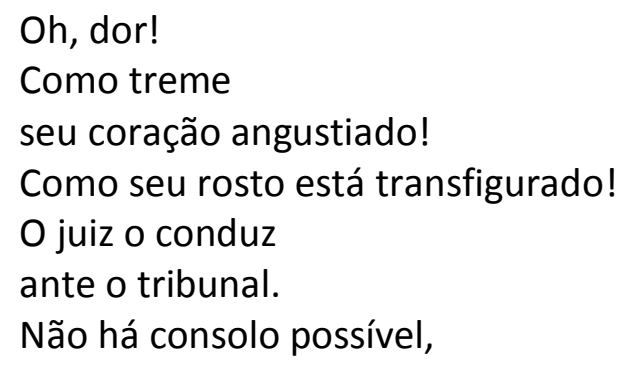

178 "Sanfte soll mein Todeskummer, Nur ein Schlummer, Jesu, durch dein Schweißtuch sein. Ja, das wird mich dort erfrischen Und die Zähren meiner Pein Von den Wangen tröstlich wischen." 
nem ajuda.

Ele padece o tormento do inferno, expiado pelos pecados dos outros.

Ah! Se meu amor pudesse,

Meu Salvador, acalmar o teu pavor, ou ajudar-te a suportá-lo.

Que grato me seria acompanhar-te!

A que se devem

estes tormentos?

Ah! são meus pecados

a causa dos teus padecimentos!

Senhor Jesus,

fui eu quem pequei e

és Tu que os expiarás! ${ }^{179}$

Tais exclusividades no uso do instrumento não passam despercebidas e mostram a preocupação do compositor com o potencial de suas possibilidades alegóricas.

\footnotetext{
179 "O Schmerz!

Hier zittert das gequälte Herz;

Wie sinkt es hin, wie bleicht sein Angesicht!

Der Richter führt ihn vor Gericht.

Da ist kein Trost, kein Helfer nicht.

Er leidet alle Höllenqualen,

Er soll vor fremden Raub bezahlen.

Ach, könnte meine Liebe dir,

Mein Heil, dein Zittern und dein Zagen

Vermindern oder helfen tragen,

Wie gerne blieb ich hier!

Was ist die Ursach aller solcher Plagen? Ach! meine Sünden haben dich geschlagen; Ich, ach Herr Jesu, habe dies verschuldet Was du erduldet."
} 


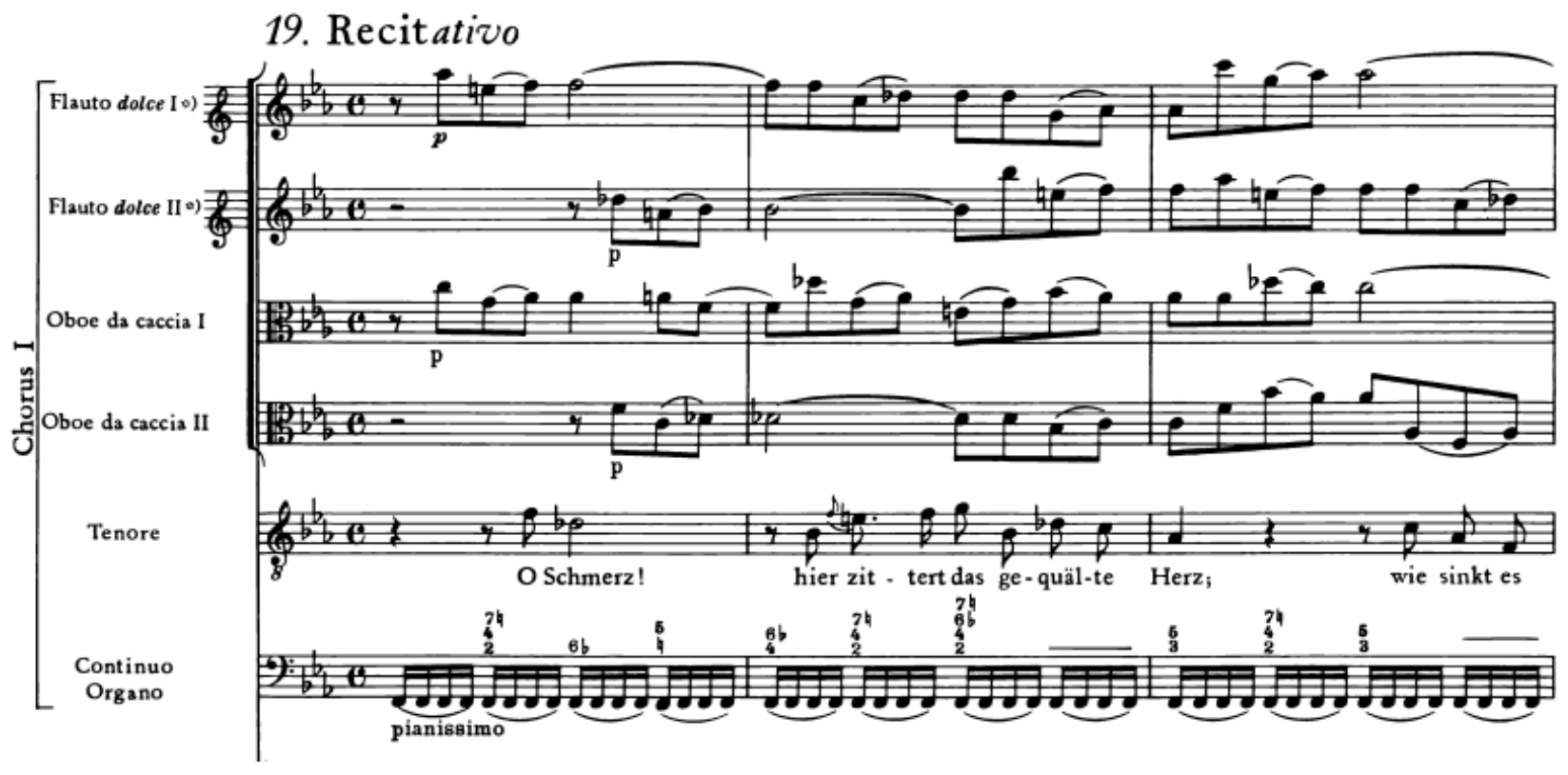

Fig. 41 - Início do recitativo no. 19 da Paixão segundo São Mateus, BWV 244, único momento da obra no qual flautas doces são utilizadas pelo compositor

O contato com o repertório da flauta doce permite a visão de que, apesar de fadada ao desuso logo após a época de Bach, ela gozou do devido respeito musical até o século XVIII e seu uso alegórico não foi de forma alguma menosprezado pelos compositores, que o utilizaram à mesma altura daquele referente aos outros instrumentos de sopro de madeira. 


\subsection{A flauta transversal}

A história mais recente da música europeia consagrou o uso de dois tipos distintos de flautas, para as quais formaram-se, ao longo do tempo, importantes repertórios. Do século XVI ao XVIII, encontram-se claros indícios de que tanto a flauta doce como a transversal eram utilizadas para diversos fins musicais, do profano ao sacro, e que ambas coexistiram dividindo espaço no cenário musical durante muito tempo.

No entanto, fica claro que desde o século XVI os dois tipos de flautas foram muitas vezes utilizados de forma distinta. Apesar de suas relativas semelhanças, ambas parecem nunca terem sido vislumbradas como substitutas umas das outras, sendo que seu uso, a partir do século XVII e muito claramente no XVIII, é diferenciado graças a aspectos técnicos e também alegóricos. Isso se evidencia, por exemplo, através do curioso fato de que durante esse período há indícios de que flauta doce e flauta transversal raramente participavam ao mesmo tempo durante a execução de uma obra e de que isso ocorria não só devido ao fato de que muitas vezes eram os mesmos músicos que tocavam os dois instrumentos, mas também (e talvez principalmente) pelos já mencionados motivos técnicos e alegóricos. Ainda assim, percebe-se que do ponto de vista alegórico, mesmo que mostrem diferenças, as flautas não são totalmente antagonistas, guardando semelhanças em diversos aspectos.

O termo "flauta" pode ser deveras genérico, como provado pelas inúmeras vezes nas quais foi historicamente usado para descrever instrumentos diferentes, desde o antigo aulos grego até a ocarina, por exemplo. Essa generalidade tem trazido dificuldades de reconhecimento de determinados instrumentos até os dias de hoje. No que concerne à música barroca europeia, o termo foi também por vezes aplicado de forma abrangente, podendo gerar dúvidas em relação à participação da flauta transversal ou doce em determinada composição. Nesse caso, buscam-se outras evidências, como históricas e musicais, a fim de se possibilitar a distinção, como sugere Duron (1986, p. 45, tradução nossa): “(...) deve-se ter cautela, olhar as tessituras, estudar o papel simbólico dos instrumentos; por vezes, pode ser útil observar os ornamentos indicados, mais eficazes, mais fáceis em um instrumento do que em 
outro." ${ }^{180}$ Contudo, mesmo uma análise cuidadosa não torna a distinção sempre possível. Essa questão dá-se principalmente em relação à música do século XVII, mas pode ocorrer também naquela do XVIII. Entretanto, já anteriormente ao Barroco alguns termos passaram a ser utilizados justamente para definir instrumentos de forma mais clara e, no caso das flautas, há nomenclaturas tradicionais que auxiliam sua distinção.

A partir do século XVIII, a flauta transversal passa a ser normalmente designada pelo termo que evidencia a posição na qual é tocada. Portanto, o italiano flauto traverso é um dos mais utilizados, apresentando variantes em outras línguas, como o francês flûte traversière e o alemão querflöte. Um outro termo muito antigo, datando ainda do medievo, foi tradicionalmente utilizado para distinguir a flauta transversal, associando-a ao território germânico, como explica Powell (2002, p. 13, tradução nossa):

Os principais instrumentos para a execução da música culta no início da Idade Média eram os instrumentos de cordas friccionadas e dedilhadas: violino, rabeca, saltério e cítara. A flauta transversal aparece apenas ocasionalmente junto a outros instrumentos como o órgão portativo e o hurdy-gurdy, e até o século XIV, quando ela aparece na França e na Espanha, parece ter sido conhecida apenas no Sacro Império Romano, ou nas terras livremente conhecidas como Alemanha. Essa é provavelmente a fonte das designações flûte d'Allemagne e German flute para o instrumento transversal. ${ }^{181}$

Apesar disso, as conexões do instrumento com a França já pareciam fortes no século XVI, como mostra a opinião de François de Scepeaux, Sieur de Vielleville e Marechal de França, que

comentou após uma noite de música de câmara em Metz em 1554 que a flauta transversal 'é muito erroneamente chamada de flauta alemã: pois os

\footnotetext{
180 "faire preuve de prudence, regarder les tessitures, étudier le rôle symbolique de l'instrument; il peut être utile parfois d'observer les ornements indiqués, plus efficaces, plus aisés sur un instrument que sur l'autre."

181 "The principal instruments for performing art music in the early Middle Ages were the bowed and plucked strings: fiddle, rebec, harp, psaltery, and gittern. The transverse flute appears only occasionally along with other instruments such as portative organ and hurdy-gurdy, and until the fourteenth century, when it appears in France and Spain, seems to have been known only in the Holy Roman Empire, or the lands loosely known as Germany. This is problably the source of the designations flutte d'Allemagne and 'German flute' for the transverse instrument."
} 
franceses fazem melhor e mais musical uso dela do que qualquer outra nação'. (POWELL, 2002, p. 44, tradução nossa) $)^{182}$

De qualquer modo, o termo foi amplamente utilizado até o século XVIII, podendo ser encontrado em diversos documentos datando mesmo do final do período.

A flauta transversal barroca, o instrumento de corpo cônico e uma chave, é uma invenção do século XVII, provavelmente da segunda metade do período. Não é possível, entretanto, afirmar a data de seu surgimento nem o responsável por sua confecção. A França teria sido um dos mais prováveis palcos para o acontecimento, mas alguns instrumentos remanescentes do período e muito provavelmente provenientes de outros locais ajudam a criar dúvidas a esse respeito. Não obstante, a conexão da flauta barroca com o território francês é notável, sendo ali o principal local de seu florescimento no meio musical: a França produziria os primeiros grandes construtores e intérpretes do instrumento, além de ser pioneira na sua utilização.

O tipo de instrumento dito "barroco" podia ser visto como uma transformação da flauta transversal tenor renascentista, mas apresentava características muito distintas de construção que modificavam suas possibilidades técnicas e sonoridade. Enquanto a flauta renascentista, com seu corpo cilíndrico e nenhuma chave, apresentava dificuldades na produção de algumas notas e era musicalmente mais utilizada em sua pungente região aguda, a flauta barroca mostrava-se cromática em toda sua extensão, com sonoridade mais escura e aveludada, principalmente em sua região mais grave.

Na corte de Luís XIV, em fins do século XVII, a flauta transversal barroca iniciou um processo de popularização que viria a torná-la um dos instrumentos preferidos de músicos profissionais e amadores. Nesse ambiente, Philbert Rebillé e René Pignon Descoteaux são apontados como os primeiros grandes intérpretes do instrumento, cujas qualidades teriam encantado não somente a corte, mas também o próprio rei.

182 "remarked after an evening of chamber music at Metz in 1554 that the transverse flute is quite wrongly called German flute: for the French make better and more musical use of it than any other nation'." 
Michel de La Barre, outro grande flautista de Versalhes, comenta em uma carta escrita por volta de 1735:

O Rei, bem como toda a corte, a quem esse instrumento [a flauta transversal] agradava infinitamente, criou dois postos junto às quatro musettes de Poitou e os deu a Philbert e Descoteaux, e eles me contaram diversas vezes que o Rei, ao conceder-lhes os postos, havia dito que desejava fortemente que as seis musettes pudessem se metamorfosear em flautas transversais, de forma que ao menos elas seriam úteis, enquanto que as musettes eram apropriadas apenas para as danças de camponeses. (PROD'HOMME, 1912, p. 245, tradução nossa) $)^{183}$

Um trecho do Mercure de France, de 10. de junho de 1725, também afirma a admiração de Luís XIV pelos dois músicos:

Luís XIV tinha muito prazer ao ouvir essas duas pessoas exprimirem cantos melodiosos em suas flautas, e com frequência pedia-lhes que o fizessem em seus apartamentos e bosques de Versalhes. (1725, p. 1081, tradução nossa) $)^{184}$

O gosto pelo instrumento certamente causou o aumento de sua procura e, consequentemente, de sua produção. Assim, luthiers da corte francesa, como os Hotteterre, destacar-se-iam na construção de flautas transversais.

A flauta transversal barroca foi utilizada musicalmente tempos antes da publicação daquele que é considerado seu primeiro repertório original. Essa utilização pode ser vista como um excelente exemplo do viés alegórico através do qual o instrumento era primordialmente vislumbrado. O primeiro papel desempenhado pela flauta transversal barroca em meio ao ambiente cortesão foi o de acompanhar o canto em árias e canções de caráter predominantemente amoroso. O novo instrumento permitia ao intérprete diversas inflexões, variações de dinâmicas e expressão que eram consideradas muito próximas da voz humana. Essas possibilidades tornavam-no muito expressivo e, consequentemente, um favorito na interpretação do tipo de

\footnotetext{
183 "le roy aussibien que toute la cour, a qui cet istrument plut infiniment, adiouta deux charges aux quatres musettes de poitou, et les donna à Philbert et à Descoteaux, et ils mont dit plusieurs fois que le roy leur auoit dit en les leur donnant quil souhaitoit fort que les six musettes fussent metamorphosees en flutes traversieres, qua moins elles seroient utilles, au lieu que les musettes nestoient propre qua faire danser les paisanes."

184 "Louis XIV. se fasoit un vrai plaisir d'entendre ces deux personnes exprimer des chants melodieux sur leurs flutes, \& les faisoit souvent venir pour cela dans ces appartements, \& dans les bosquets de Versailles."
} 
música que inspirava-se nas diversas facetas do amor e a delicadeza característica da sonoridade do instrumento parecia encantar grande parte de seus ouvintes.

Assim, os primeiros intérpretes do instrumento tinham nas airs de cour e brunettes seu principal repertório. Como explica Powell (2002, p. 61, tradução nossa),

os nomes de Philbert e Descoteaux, ambos famosos tanto por seu canto quanto por sua interpretação à flauta, tornaram-se sinônimos do caráter triste, afetuoso e lânguido do instrumento nas últimas décadas do século XVII. Essa fama pessoal claramente ajudou a promover a reputação da flauta (....). ${ }^{185}$

O autor cita também o obituário de Descoteaux, datado de 1728, no qual diz-se que o músico teria sido "um dos primeiros a tornar a flauta transversal conhecida" e que "ele raramente tocava algo diferente de pequenas árias [petites airs tendres], mas com gosto e clareza sempre encantadores." (2002, p. 62, tradução nossa) $)^{186}$

O gosto pela execução desse tipo de música na flauta transversal tornou-se uma inegável tradição na França, como provam as publicações de livros de peças do gênero para o instrumento ainda na primeira metade do século XVIII. Montéclair, no prefácio de suas Brunettes Anciennes et Modernes (1725), escreve que "nada é tão tocante quanto ouvir pequenas árias cantadas por uma bela voz acompanhada em uníssono por uma flauta transversal." A relevante conexão do instrumento com esse gênero musical é também sugerida no prefácio das Pièces pour la Flûte Traversière, do já mencionado Michel de La Barre, publicadas em 1702 (a primeira coleção de obras escritas originalmente para a flauta transversal a ser publicada). Ao comentar sobre o gênero das peças que formam a publicação, no geral danças organizadas em suítes, o autor explana, no Avertissement da coleção: "Essas peças são na sua maioria de um caráter tão especial e tão diferentes da ideia que as pessoas têm tido até o momento a

\footnotetext{
185 "The names of Philbert and Descoteaux, both of whom were famous for their singing as well as their transverse flute playing, became synonymous with the instrument's sad, tender, and languising character in the last decades of the seventeeth century. Their personal fame clearly did much to promote the flute's reputation (...)"

186 "He was one of the first to make it fashionable. He scarcely played anything but little delicate airs [petites airs tendres], but with charming taste and neatness."
} 
respeito do que convém à flauta transversal, que eu decidi não deixá-las vir à luz senão tocando-as eu mesmo." (LA BARRE, 1702, tradução nossa) $)^{187}$

De fato, o instrumento já vinha sendo utilizado em outros gêneros musicais em fins do século XVII, como prova seu uso na ópera e também em música instrumental de câmara como, por exemplo, em uma Sonate (c.1686) atribuída a Charpentier e nas Pièces em trio de Marais (1692), cujo título sugere o uso de flautas como possível instrumentação ("pour les flutes, violons et dessus de viole"). Apesar do termo "flutes" não definir flautas doces ou transversais, o frontispício da edição, adornado com ilustrações de diversos instrumentos, mostra claramente a representação de um tipo de flauta transversal muito semelhante ao modelo barroco do instrumento.

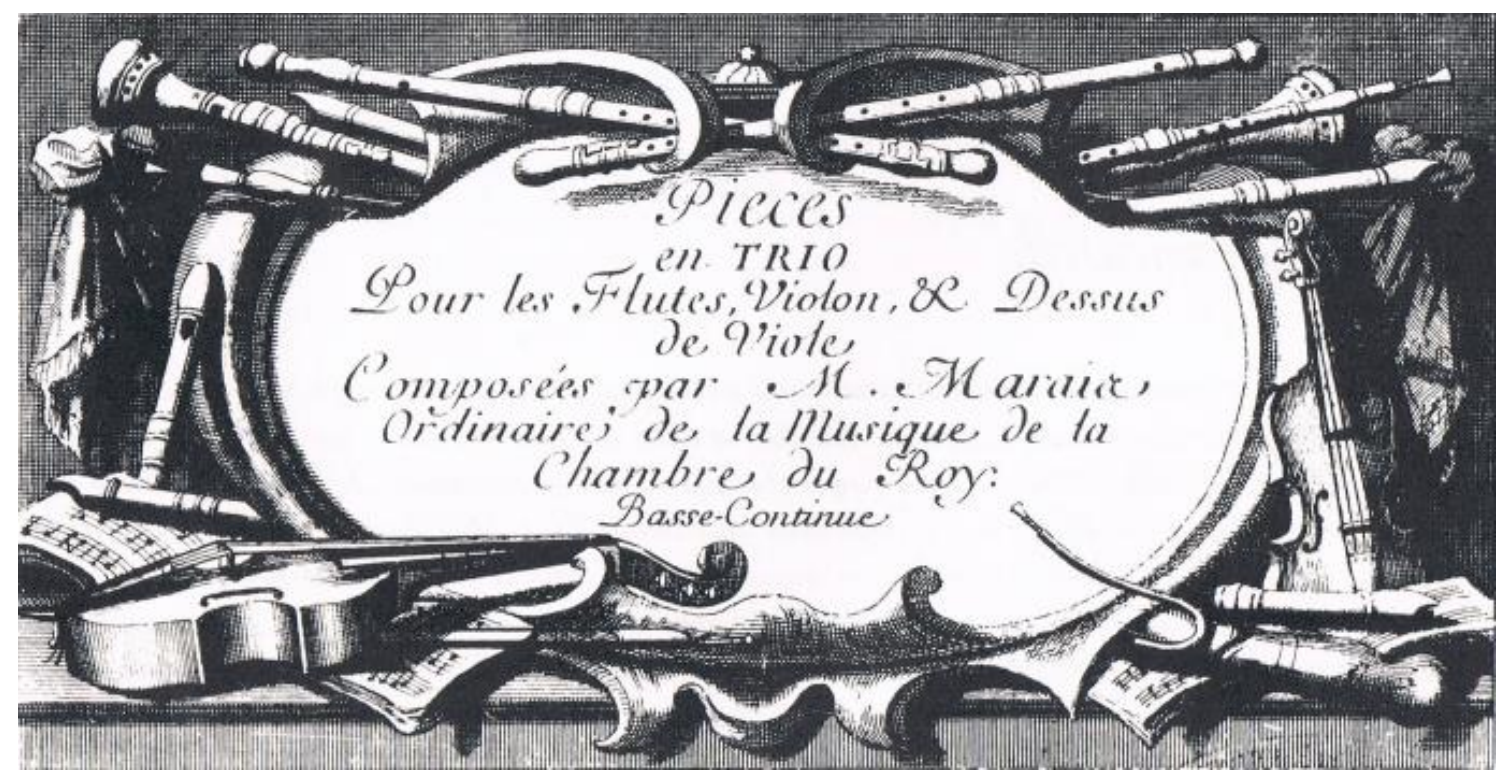

Fig. 42 - Frontispício da parte de baixo contínio da primeira edição das Pièces en Trio, de Marais (1692). Duas flautas transversais são vistas no topo da gravura.

De qualquer modo, fica claro que no início do século XVIII a flauta transversal ainda era vista desempenhando a sua primeira função junto ao canto, reiterando suas qualidades de instrumento terno, sensível e melancólico. Powell (2002, p. 64, tradução nossa) comenta a respeito da moda francesa que "associava flautas transversais a sentimentos de charme e amor" em fins do século XVII. ${ }^{188}$

\footnotetext{
187 “Ces pièces sont pour la plus grande partie d'un caractère si singulier et si différentes de l'idée qu'on a eue jusques ici, de celles qui conviennent à la Flûte Traversière, que j'avais résolu de ne leur faire voir le jour qu'en les exécutant moi-même."

188 "associates flutes with feelings of charm and love."
} 
Lully foi o primeiro a especificar o uso da flauta transversal barroca em uma obra. É importante lembrar que compositores de outras localidades da Europa já haviam solicitado o uso do instrumento em sua música anteriormente, como afirma Powell (2002, p. 49, tradução nossa): “Os compositores alemães Schein, Schütz e Praetorius especificaram flautas transversais para os seus papéis mais notáveis do início do século XVII em 'concertos sacros' e 'sinfonias sacras'"189. No entanto, o instrumento para o qual escreveram era muito provavelmente a flauta de modelo renascentista, como o período histórico e o tipo de escrita idiomática musical sugere. Portanto, as participações das flûtes d'Allemagne na opéra-ballet Le Triomphe de L'Amour, de 1681, são consideradas o provável début da flauta transversal barroca em voga na época de Lully. A partitura do compositor pede pelo instrumento em apenas dois momentos: um ritornello para a deusa Diana e um prelúdio para o Amor. No primeiro, duas flautas transversais são usadas em trio com o baixo contínuo e no segundo, o instrumento assume a voz mais aguda em um coro completado por flautas doces mais graves, além do baixo contínuo. $\mathrm{O}$ uso das flautas transversais isoladas e em conjunto com as flautas doces em uma mesma obra mostra a preocupação do compositor com a obtenção de diferentes cores sonoras, além de sugerir um emprego simbólico dos instrumentos.

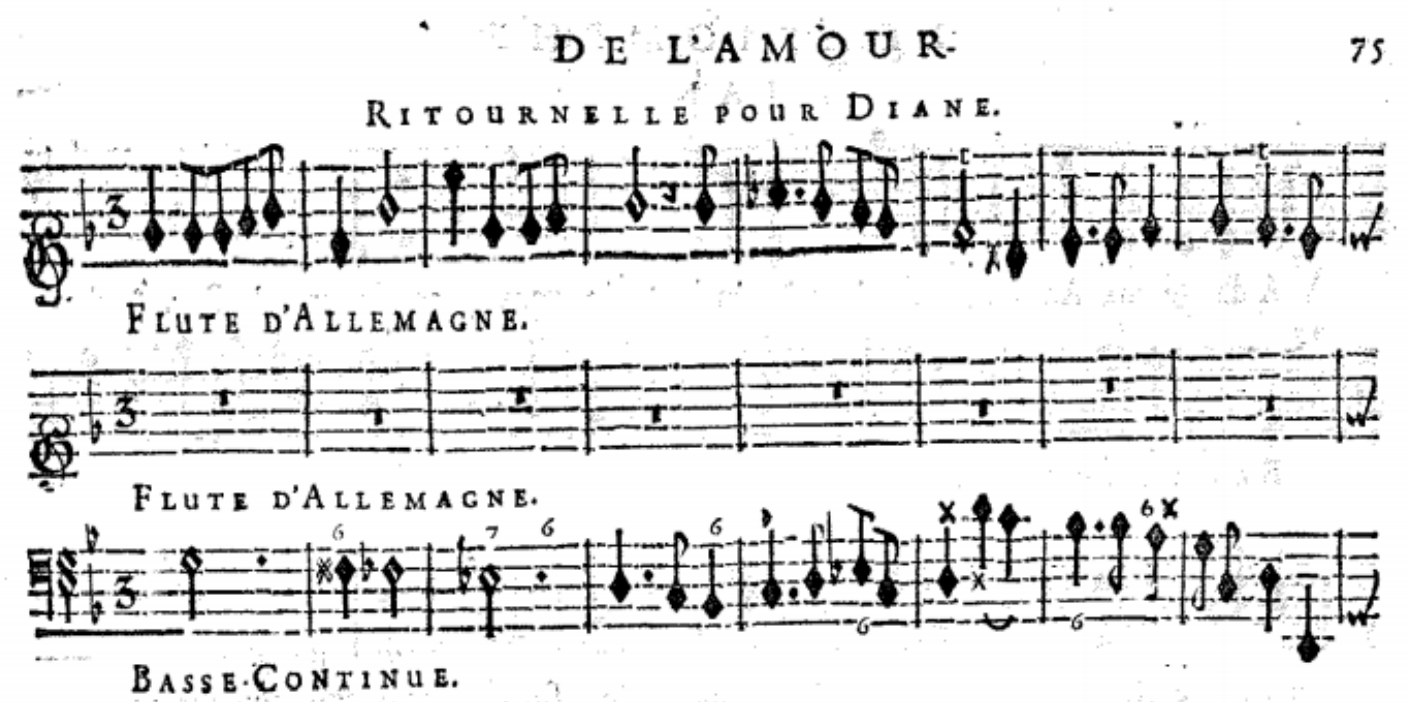

Fig. 43 - Início do Ritornello pour Diane em Le Triomphe de L'Amour, de Lully. Vê-se a indicação das flautas transversais (Flutes d'Allemagne), uma das únicas em toda a obra impressa do compositor (1681)

\footnotetext{
189 "German composers, Schein, Schütz, and Praetorius, specified transverse flutes for their most notable roles of the early seventeenth century in 'sacred concertos' or 'sacred symphonies'."
} 
O livret contendo o texto da opéra-ballet indica a entrada da referida deusa descrevendo-a da seguinte forma: "Diana, vestindo roupas de caça, canta e mostra que despreza o poder do Amor". O texto cantado por Diana (1681, p.14, tradução nossa), deixa claro que ela busca distância das consequências de seus feitos:

Vá, perigoso Amor, vá, fuja para longe desses Bosques, Quero neles conservar a paz e a inocência.

Os maiores Deuses a ti cederam milhares de vezes, E eu pretendo sempre a ti resistir.

Quanto mais se vê grandes Corações escravizados por tuas leis, Mais belo é desafiar teu poder. ${ }^{190}$

Apesar de toda sua convicção, a deusa da caça logo sucumbe aos desejos contra os quais diz lutar, como também narrado no livret (1681, p.16, tradução nossa): "Endimyon se aproxima de Diana e de suas Ninfas; a severa deusa quer fugir com elas, mas não pode evitar olhar Endymion, e se retira, toda confusa por sentir-se tocada de amor por ele."191

Sendo a flauta transversal um instrumento então considerado muito indicado para a potencialização dos cantos de amor, dos suspiros amorosos das airs de cour, não é difícil compreender a escolha de Lully ao solicitar o instrumento no melancólico ritornello que antecede a entrada da referida deusa, como um provável presságio do iminente acontecimento envolvendo a paixão indesejada que tomará o coração de Diana. A presença da sonoridade do instrumento no prelúdio que antecede a entrada da figura do próprio Amor é também, nesse contexto, compreensível. O efeito causado pela participação da flauta transversal não poderia passar despercebido.

Le Triomphe de l'Amour é a única obra de Lully na qual o compositor especifica a presença da flauta transversal. Todavia, isso não significa que ela não tenha sido

\footnotetext{
190 “Va, dangereux Amour, va, fuy loin de ces Bois, Je veux y conserver la paix \& l'innocence. Les plus grands Dieux t'ont cedé mille fois, Et je pretens toujour te faire resistence. Plus on voit des grands Coeur asservis à tes loix, Plus il est beau de braver ta puissance."

191 "Endymion s'approche de Diane \& de ces Nymphes; Cette Déesse si severe veut fuir avec ses Nymphes, mais elle ne peut s'empécher de regarder Endymion, \& se retire toute confuse de se sentir touchée d'amour pour luy."
} 
empregada junto aos grupos instrumentais em outras de composições suas, como comenta Rowland Jones (2009, p. 248, tradução nossa):

(...) é curiosos que ele [Lully] nunca tenha especificado nenhum outro uso desse instrumento em suas obras dramáticas posteriores, apesar dele [a flauta transversal] poder ter possivelmente dobrado os violinos algumas vezes mesmo sem ter sido indicado na partitura. ${ }^{192}$

Em relação às questões alegóricas envolvendo a flauta doce, citadas anteriormente, é possível tecer certa semelhança com aquelas relacionadas à flauta transversal no contexto envolvendo o amor e suas representações. Como visto, ambas as flautas são, já no século XVII, utilizadas como alegoria para o amor. Apesar disso, há indícios de que o tipo de amor alegoricamente traduzido por elas possa ter sido de naturezas diferentes. Viu-se que o amor representado pela flauta doce, ao menos para o círculo musical de Lully, está muito conectado à inocência e ternura. Já a flauta transversal poderia ter sido vista mais conectada ao amor carnal, aos jogos de conquista, e às dores amorosas tão presentes na temática comum das airs de cour, que tanto se destacavam em meio a seu repertório. No entanto, exceções ocorreriam.

Duron fala de uma distinção entre o uso alegórico das flautas como representantes do amor na obra de Charpentier, como já visto. Para o autor, o uso que Charpentier faz do trio de duas flautas transversais e contínuo "parece ligado à ideia de prazer, de alegria e de charme" (1986, p. 52, tradução nossa) ${ }^{193}$. O próprio Duron indica que essa ideia é contrária à caracterização que Brossard dá ao instrumento em seu dicionário de música de 1703 (p. 133), em que a flauta transversal é dita como sendo própria para um estilo triste e lânguido.

No que diz respeito à representação do tema pastoral, a flauta doce estará mais em evidência até o século XVIII. No entanto, conforme caminha em direção ao desuso, o instrumento parece transmitir parte de sua simbologia à flauta transversal, como ocorrerá com aquela do assunto pastoral. Contudo, não é possível dizer que essa representação não fizesse parte também do universo da flauta transversal desde muito antes, uma vez que, por sua própria natureza, muitos instrumentos de sopro de

\footnotetext{
192 “(...) it is curious that he never specified any other use of this instrument in his later dramatic works, although it could possibly have sometimes doubled the violins without being indicated in the scores." 193 "semble liée à l'idée de plaisir, de joie, de charme."
} 
madeira sempre estiveram intrinsecamente conectados a aspectos pastoris. Além disso, as próprias árias e brunettes da corte francesa, tão propícias à flauta transversal barroca, não raro evocavam o universo idealizado dos pastores.

O início do século XVIII vê o surgimento de um repertório original para a flauta transversal, com a publicação de diversos livros de peças para o instrumento acompanhado de baixo continuo, bem como de duos para duas flautas. Obras de Michel La Barre, Pierre Danican Philidor e Jacques-Martin Hotteterre Le Romain destacam-se como o primeiro repertório do instrumento, essencialmente francês. Segundo Powell,

enquanto Campra, Charpentier e outros compositores franceses continuavam a escrever para a flauta transversal em sua música sacra e teatral, ela entrou em uma fase inteiramente nova como um instrumento solista, dentro de uma configuração mais privada que permanecia na corte. $(2002, \text { p. 71, tradução nossa) })^{194}$

A urgência do surgimento dessas publicações camerísticas durante o período evidencia a popularização do instrumento. Logo, a técnica de execução da flauta transversal barroca, que vinha se desenvolvendo há décadas, poderia e deveria ser descrita e mais amplamente difundida. Em 1707, o mesmo Hotteterre publica seu Principes de la flute traversiere ou flute d'Allemagne, de la flute a bec ou flute douce et du haut-bois, contendo explicações do autor, ele mesmo um flautista renomado, para o domínio técnico do instrumento bem como da flauta doce e do oboé, como o sugere o título da obra. Em seu prefácio, o autor não deixa de citar o fato do instrumento ter se tornado muito popular já naqueles dias: "Como a flauta transversal é um instrumento dos mais agradáveis, e dos que mais estão na moda, pensei dever empreender essa pequena obra, a fim de apoiar a inclinação daqueles que aspiram tocá-lo". (1707, p. 1, tradução nossa) $)^{195}$

Um repertório original e escrito por bons conhecedores do instrumento servirá de exemplo em relação à escrita idiomática. As peças para flauta transversal são compostas a fim de valorizá-la em todos os seus aspectos, buscando o máximo de sua

\footnotetext{
194 "While Campra, Charpentier, and other French composers continued to score for it in theatrical and sacred music, the flute entered an entirely new phase as a solo instrument in the more private settings that continued to prevail at court."

195 “Comme la Flute Traversiere, est un Instrument des plus agréables, \& des plus à la mode, j'ay cru devoir entreprendre ce petit ouvrage, pour seconder l'inclination de ceux qui aspirent à en joüer."
} 
expressão através de uma escrita musical baseada nas facilidades e naquilo que é mais natural e orgânico no instrumento. Consequentemente, ele começa a ganhar uma linguagem própria, que o diferencia dos outros. Entre diversos aspectos, a escrita idiomática da flauta transversal barroca caracteriza-se pela valorização da região grave do instrumento (muito benquista graças à sua sonoridade aveludada e encorpada) e pelo uso de tonalidades que a favorecem, normalmente aquelas com sustenidos, principalmente ré, sol e lá maior e algumas de suas relativas menores (fá sustenido menor é possível, mas não muito comum).

Sendo assim, a partir do século XVIII as diferenças de escrita para as flautas doce e transversal tornam-se mais evidentes e os compositores que melhor conhecem os instrumentos saberão explorar essas diferenças.

A popularização da flauta transversal levou-a para fora da França e, já nas primeiras décadas do século XVIII, o instrumento era conhecido e utilizado em outros grandes centros europeus como Inglaterra e Alemanha. No mesmo período, a influência da música italiana passa a se mostrar mais presente em seu repertório e a tendência à virtuosa escrita instrumental violinística que se espalhava em meio a diversos instrumentos também começa a ser vista na música para flauta transversal.

Entretanto, o instrumento continua a ser alegoricamente utilizado para fins semelhantes aos do século anterior. Como mostram as descrições setecentistas da flauta nos tratados, ela ainda é considerada como o instrumento da delicadeza, sutileza, amorosidade, tristeza e recolhimento.

Rameau fez uso prolífico da flauta transversal em suas óperas, sendo que o instrumento figura em diversos momentos destas obras, muitas vezes como solista, auxiliando na composição de diferentes cores orquestrais. Chama atenção também a clara preferência do compositor pelo instrumento transversal, o que acarreta na quase que total exclusão da flauta doce de sua orquestra. Apesar de suas inovações na escrita orquestral, Rameau utiliza a flauta transversal alegoricamente de forma mais tradicional. Embora o instrumento seja às vezes empregado de forma não-usual (como na já mencionada representação de relâmpagos ou ventanias em algumas cenas de tonerre), a flauta é normalmente usada em cenas pastorais e amorosas. Do ponto de vista da orquestração, segundo Powell, a utilização da flauta por Rameau prefiguraria o estilo clássico, sendo que o compositor "antecipou o papel da flauta que se tornaria 
comum mais tarde naquele mesmo século XVIII" (2002, p. 85, tradução nossa) ${ }^{196}$. Esse papel seria caracterizado, por exemplo, pelo uso da flauta em sua região mais aguda, normalmente acima dos outros instrumentos da orquestra. De qualquer forma, isso não alteraria sua aplicação alegórica na música.

Um estudo de Kauffman sobre as possibilidades de representação alegórica da escrita orquestral dos violons en basse (2006) reforça a ideia da flauta transversal como símbolo pastoral. A autora define o termo francês como

\begin{abstract}
um tipo incomum de orquestração encontrada em árias de compositores barrocos franceses, incluindo Couperin, Campra e Rameau. Nessas peças, a linha do basse continue é tocada por violinos ou violas notadas em uma clave aguda; a voz solo e qualquer instrumento obbligato adicional permanece no registro de soprano (...) Um estudo dos textos das árias nas quais os violons são usados en basse sugere que há identificáveis associações alegóricas implícitas nessas peças, e que elas eram claras para os ouvintes da época. (2006, p. 184-185, tradução nossa) $)^{197}$
\end{abstract}

Kauffman continua sugerindo a natureza dessas associações:

Talvez a mais importante e mais frequente referência seja ao tema pastoral, que é invocado pelos textos e configurações musicais de um bom número de árias. $O$ pastoral pode também ser conectado aos temas de paz e deleites da quietude presentes em outros textos. Outra importante associação compartilhada com o pastoral é a inocência, que é com frequência conjecturada com a ideia de juventude; a juventude é diretamente referida em alguns textos e também através de vários personagens que os cantam, como o Cupido (um menino), Diana (descrita na mitologia como eternamente jovem) e Hebe (a personificação da juventude). (2006, p. 185, tradução nossa) ${ }^{198}$

Assim, o uso de instrumentos obbligati com conotações pastorais, entre eles a

flauta transversal, junto desse tipo de orquestração seria auto-explicativo:

\footnotetext{
196 "anticipated a role for the flute that was to become common later in the century."

197 "An unusual type of orchestration sometimes called violons en basse is encountered in arias by French Baroque composers, including Couperin, Campra, and Rameau. In such pieces, the basse continue line is played by violins or violas notated in a high clef; the solo voice and any additional obbligato instruments remain in the treble register as well. (...) A study of the texts of the arias in which violons are used en basse suggests that there are identifiable allegorical associations implicit in such pieces, and that they were clear to listeners of the time."

198 "Perhaps the most important and most frequent reference is to the pastoral, which is invoked by the texts and musical settings of a number of the airs. The pastoral can also be linked to the themes of peace and quiet delights present in other texts. Another important association shared with the pastoral is innocence, which is often conjoined with the idea of youth; youth is directly referred to in some texts, and also through several personages who sing them, such as Cupid (a boy), Diana (depicted in mythology as eternally young), and Hebe (the personification of youth)."
} 
Podemos concluir que o aparecimento de violons en basse coincide com um grupo de tópicos estreitamente relacionados que giram em torno do pastoral. Isso é particularmente claro quando um oboé ou - muito mais frequentemente - uma flauta é incluída na textura musical. (2006, p. 183, tradução nossa) ${ }^{199}$

A forte associação da flauta com o pastoral seria aqui reforçada pelo fato do instrumento ser "muito comumente usado como obbligato nas árias desse estudo; mais de dois terços a incluem, em solo ou em par." (2006, p. 173, tradução nossa) 200

Não surpreendentemente, a flauta transversal, assim como a flauta doce e eventualmente outros instrumentos de sopro de madeira, foi também muito empregada na imitação de cantos de pássaros. Ainda que a flauta doce pareça ter sido a mais contemplada com esse tipo de imitação até a primeira metade do século XVIII, o repertório da flauta transversal apresenta muitos desses exemplos, da música de câmara até a operística. No entanto, se uma comparação desse tipo de uso do instrumento pode ser feita, principalmente em relação à utilização da flauta doce para o mesmo fim, não parece errôneo supor que os cantos das aves representados pela flauta transversal são normalmente mais calmos e amorosos do que cheios de uma excitação saltitante e frenética. Não à toa, a flauta transversal é muito frequentemente associada ao rouxinol, ave tradicionalmente representada por cantos melodiosos e suaves. Essa associação é muito bem exemplificada nas palavras de François Couperin, que ao escrever a respeito das possíveis instrumentações para suas Pièces de Clavecin, indica que a peça Le Rossignol-en-amour, publicada no terceiro livro da coletânea (1722), "não poderia ser mais bem sucedida do que na flauta transversal, quando bem tocada." (1722, p.12, tradução nossa) ${ }^{201}$

Ao tratar do uso da flauta transversal na música vocal de Handel, Lasocki afirma que o compositor "escreveu em torno de oitenta árias e outros movimentos que incluíam o instrumento" (2002, p. 5, tradução nossa) ${ }^{202}$. O autor comenta a respeito da relevância do uso da flauta como "efeito especial" em meio à orquestra de Handel:

\footnotetext{
199 "We may conclude that the appearance of violons en basse coincides with a group of closely related topics that revolve around the pastoral. This is particularly clear when an oboe or-much more frequently - a flute is included in the musical texture."

200 "very commonly used obbligato instrument in all the airs in this study; more than two-thirds include them, either as a single obbligato instrument or a pair."

201 "reüssit sur la flute traversiere on ne peut pas mieux: quando il est bien joüé."

202 "wrote about eighty arias and other movements that included the flute."
} 
Com poucas notáveis exceções em sua obra mais tardia, Handel não deu à flauta uma música virtuosística, e no papel ela pode parecer maçante. Mas, considere-se o contexto: o som orquestral era predominantemente o de cordas, com frequência dobradas por oboés e fagotes. Para uma ou mais árias especiais descrevendo certos afetos ou situações, os oboístas tomavam suas flautas e criavam uma espantosa cor sonora, sozinha ou em dobra com os violinos. (2002, p.5, tradução nossa) $)^{203}$

Lasocki ressalta o uso handeliano da flauta de acordo com algumas associações alegóricas, para as quais cita exemplos de árias e outros trechos encontradas em óperas e oratórios do compositor. Segundo ele, "a principal associação da flauta é com a tristeza, o luto e a dor (especialmente a relacionada à partida da pessoa amada)", mas também haveria associações com o amor ("com uma visão de seus aspectos difíceis ou lamentando a crueldade do amado"), com a eternidade (voltada ao religioso) e com representações dos princípios de masculino e feminino. Lasocki ressalta o uso do instrumento na ária The soft complaining flute, na Ode for Saint Cecilia's Day, HWV 76, cujo texto, “com suas referências a 'notas que morrem', 'infortúnios', 'amantes desesperançados', 'lamentação' e 'sussurros', trazem à mente a caracterização do instrumento feita pelo francês Raguenet em 1702." (2002, p. 5-6, tradução nossa) ${ }^{204}$.

O autor fala também sobre o uso da flauta transversal em imitação de pássaros: "Handel escreveu quatro representações de cantos de pássaros para a flauta doce entre 1711 e 1734 (...) Antes e depois desse período ele usou a flauta transversal [para o mesmo fim]", sendo que

a ária mais espetacular com flauta obbligato também descreve cantos de
pássaros, Sweet Bird, that shuns't the noise of Folly, de L'Allegro, II
Penseroso ed il Moderato (1740). Em relação à escolha do instrumento Levin
comenta: "A associação chave pode muito bem ser a 'melancolia', evocada
da melhor forma pela flauta transversal; também 'noite' sugere uma

203 "With a few notable exceptions later in life, Handel did not give the flute virtuoso music, and on paper it can appear dull. But consider the context: the orchestral sound was predominantly strings, often doubled by oboes and bassoons. For one or more special arias depicting certain affects or situations, the oboists pulled out their flutes and created a haunting tone color, alone or doubling the violins."

204 "The main association of the flute is grief, bereavement, and pain (especially that of parting from a loved one)"; "with a view of its difficult aspects, or bemoaning the cruelty of a beloved"; "with its references to 'dying notes,' 'woes,' 'hopeless lovers,' 'dirge,' and 'whispered,' brings to mind the characterization of the instrument by the Frenchman Raguenet in 1702." 
atmosfera quieta que seria perturbada pela penetrante pequena flauta doce sopranino ou flageolet. (2002, p.6-7, tradução nossa) $)^{205}$

Lasocki observa também que "em 1732 [Handel] começou a conceder à flauta transversal não só árias com temática de pássaros mas outras situações que teriam anteriormente pedido pela flauta doce." (2002, p. 7, tradução nossa) ${ }^{206}$. Entre essas situações, estariam algumas associadas aos contextos celestial, divino e pastoral.

Nota-se que as aplicações alegóricas da flauta transversal feitas por Handel, apesar de variadas, podem, em sua maioria, ser conectadas às mais tradicionais associações feitas com o instrumento desde o século XVII.

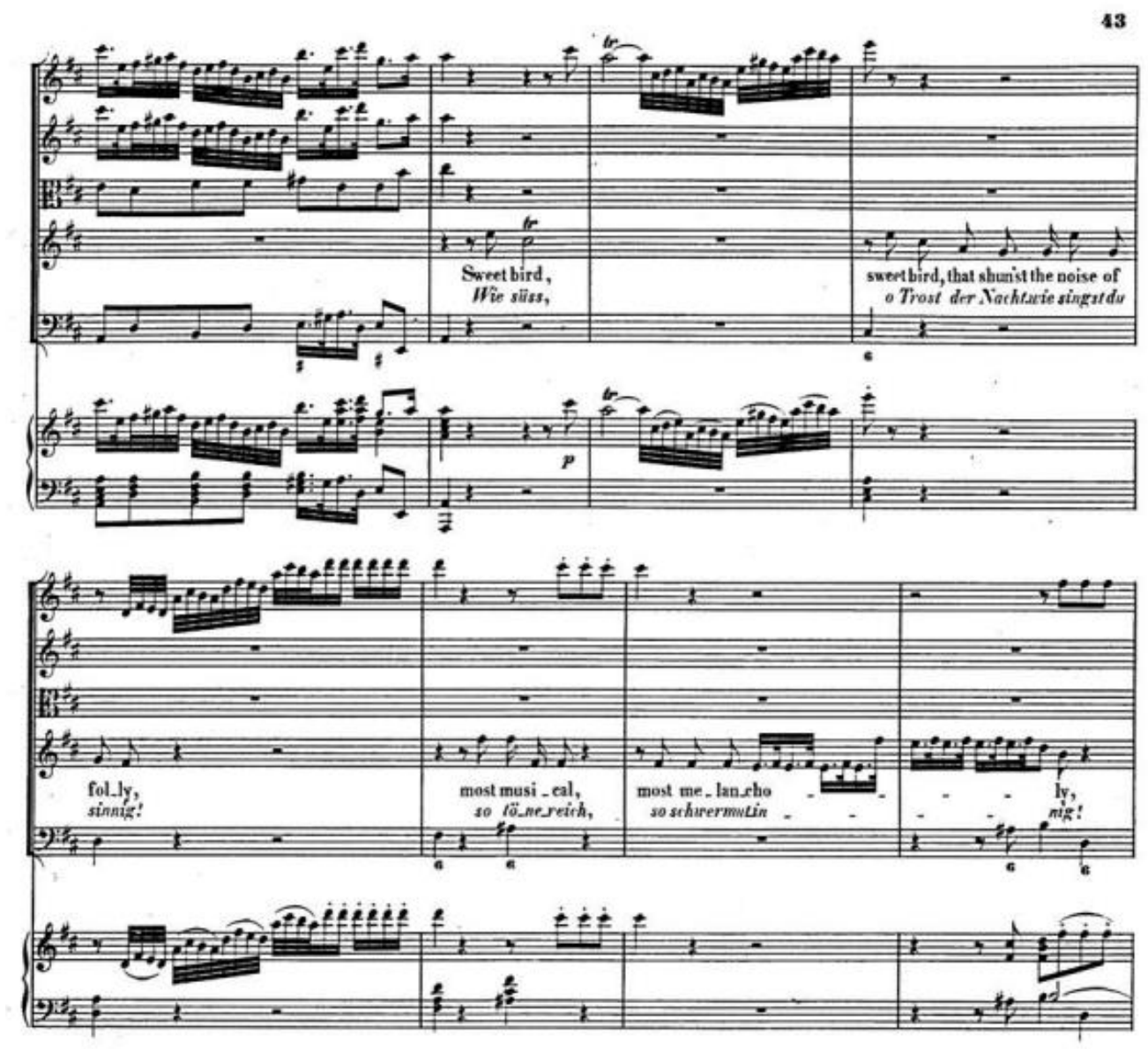

Fig. 44 - Excerto da ária Sweet Bird, that shuns't the noise of Folly, de Handel (1740). 0 primeiro pentagrama dos sistemas mostra a parte de flauta transversal, escrita em imitação do canto de um pássaro

205 "Handel wrote four depictions of birdsong for the recorder between 1711 and 1734 (...) Before and after that period, he used the flute."; "The most spectacular aria with flute obbligato also depicts birdsong, 'Sweet Bird, That Shun'st the Noise of Folly' from L'Allegro, it Penseroso ed il Moderato (1740). On the choice of instrument Levin remarks, "The key association may well be 'melancholy', evoked best by the flute; also 'evening' suggests a quiet mood which would be disturbed by the shrill little sopranino [recorder] or flageolet."

206 "In 1732 Handel began giving to the flute not only bird arias but other situations that would earlier have called for the recorder." 
A flauta transversal terá uma grande e relevante participação em meio à obra de J.S. Bach, sendo que poderá ser vista em posição de destaque tanto em composições instrumentais quanto vocais do compositor. Além de figurar em concertos, sonatas e outras formas instrumentais, ela também parece ter sido um dos instrumentos preferidos do compositor para a realização de obbligatos e outros tipos de solos em cantatas, oratórios e paixões. De fato, ali existem dezenas de exemplos desse tipo de uso da flauta transversal.

O papel alegórico que a flauta desempenha na obra vocal de Bach mostra-se rico e variado. $O$ instrumento parece ser contemplado também de forma tradicional, mas é possível que seu potencial alegórico em Bach ganhe outras dimensões em meio à música de profundo senso religioso, através da qual muitos instrumentos adquirem nova potencialidade expressiva e catártica.

As já conhecidas tendências à representação da ternura, delicadeza, amor, tristeza, etc, pela flauta transversal são aplicadas por Bach em meio a diversos desdobramentos dessas características, que podem ser vistos, por exemplo, nas árias das muitas obras vocais que utilizam a flauta.

O instrumento é usado para música de afetos diversos, da alegria à tristeza, para a qual a sonoridade da flauta traz uma ambientação de calma e recolhimento muito característicos. Muitas das árias com flauta transversal obbligato parecem construídas sobre textos focados na ideia religiosa da conformação com as dificuldades da vida junto da certeza da crença da salvação em Cristo, o que sugere que Bach possa ter aqui encarado a flauta como representante de "um conforto para aquele que crê".

A leveza característica dos sons mais agudos da flauta serve bem à sugestão de coros de anjos, como na ária Lass, o Fürst der Cherubinen, da cantata BWV 130, mas também poderia ser relacionada à alma humana, como em Meine Seele sei vergnügt, da cantata BWV 204 e em Seele, deine Spezerein do Oratório de Páscoa, BWV 249. O papel da flauta transversal como instrumento pastoral fica claro em Frohe Hirten, uma ária de pastores na segunda cantata do Oratório de Natal, BWV 248.

Na Paixão segundo São João, o instrumento é usado obbligato em duas árias de soprano, em momentos musicais muito distintos. No início da obra, na ária Ich folge dir gleichfalls, duas flautas transversais em uníssono acompanham o canto sobre um texto que trata da alegria e da coragem daqueles que seguem Jesus. No final da obra, em 
Zerfliesse mein Herze, uma flauta, junto a um oboé da caccia, auxilia na representação da profunda tristeza causada pela morte do Cristo.

A mais impressionante ária de Bach com flauta obbligato, não só por sua música em si, mas também por seu significado dentro da obra na qual está inserida, seja talvez Aus liebe will mein Heiland sterben, da Paixão Segundo São Mateus, BWV 244. Chafe (2000, p. 8, tradução nossa) comenta que

\begin{abstract}
o tremendo contraste entre essa ária - de sonoridade delicada em virtude da instrumentação de Bach para soprano e flauta transversal, com dois oboés da caccia como substitutos do baixo contínuo - e o clamor por morte nos dois coros poderosamente cromáticos "Lass inn kreuzigen" [ouvidos antes e depois dela] fazem dessa uma das mais vívidas passagens na obra, colocando a oposição entre julgamento e amor no coração da mensagem da paixão. ${ }^{207}$
\end{abstract}

A ária, que faz parte da cena que antecede a crucificação de Jesus, na qual ele é julgado, é intercalada por dois coros representando a multidão que pede por sua crucificação. Circundada pela forte e dissonante música que forma o clamor do povo, ela surge como uma espécie de meditação em meio ao tumulto, em um congelamento da cena, apresentando o seguinte texto:

Por amor meu Salvador quer morrer.

Ele não sabe nada de nenhum pecado;

Para que a danação eterna

e a punição do julgamento

não permaneçam sobre minha alma. ${ }^{208}$

\footnotetext{
207 "The tremendous musical contrast between this aria - delicate-sounding by virtue of Bach's instrumentation for soprano and flute, with two oboes da caccia as a substitute for the basso continuo and the cry for death in the two ponderously chromatic 'Lass inn kreuzigen' choruses makes this one of the most vivid passages in the work, placing the opposition of judgment and love at the very heart of the message of the passion."

208 "Aus Liebe will mein Heiland sterben.

Von einer Sünde weiß er nichts;

Dass das ewige Verderben

Und die Strafe des Gerichts

Nicht auf meiner Seele bliebe."
} 
De certa forma, essa ária contém em si a principal mensagem da paixão de Cristo, o que eleva sua importância em meio à obra como um todo. Chafe complementa sua ideia comentando que

a parte da cena do julgamento na Paixão segundo São Mateus centrada ao redor da ária "Aus liebe will mein Heiland sterben" constitui o coração ou ponto fulcral da oposição entre os sofrimentos inocentes de Jesus e o pedido da multidão por Sua morte. A seção central de "Aus liebe" deixa claro que a morte de Jesus, motivada pelo amor àquele que nele crê, remove tanto a eterna contaminação da humanidade pelo pecado quanto o julgamento de Deus. (CHAFE, 2000, p. 243, tradução nossa) ${ }^{209}$
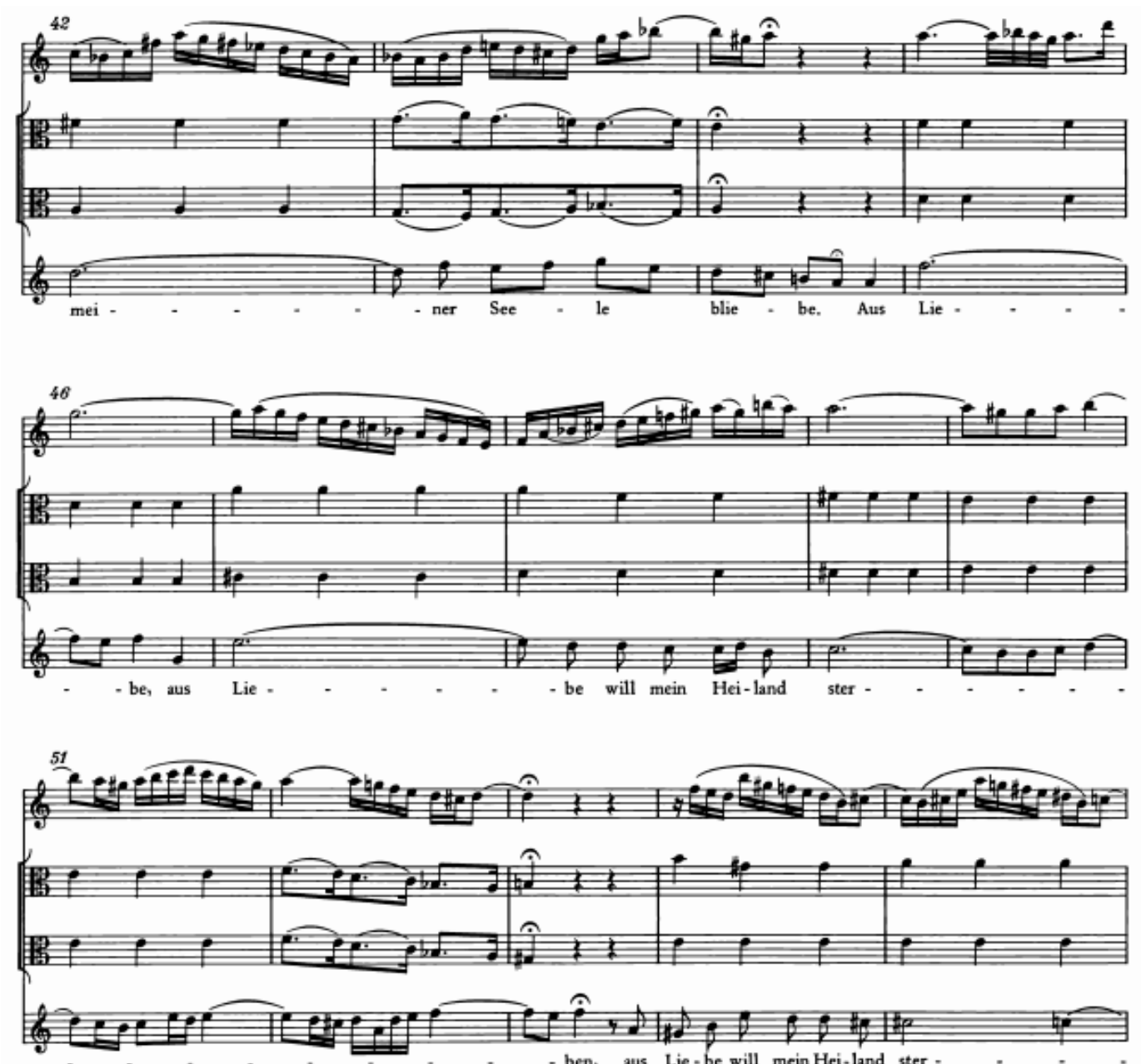

Fig. 45 - Excerto da ária Aus liebe will mein Heiland sterben, da Paixão segundo São Mateus, BWV 244, de J.S. Bach. Os pentagramas correspondem às partes de flauta transversal, oboés de caccia e soprano

209 "the part of the trial scene of the St. Matthew Passion that centers around the aria 'Aus Liebe will mein Heiland sterben' constitutes a centerpiece ('Herzstück') or focal point for the opposition between Jesus' innocent sufferings and the demand for His death from the mob. The middle section of 'Aus Liebe' makes clear that Jesus' death, motivated by love for the believer, removes both the eternal contamination of humanity by sin and God's judgment." 
A principal característica da ária que a torna tão leve e contrastante com os outros momentos da obra é o fato dela não possuir instrumentos graves (não há baixo contínuo). A orquestração de Bach pode confundir-se com a citada técnica francesa dos violons en basse (exceto que não há violinos ou violas entre os instrumentos e as partes mais graves ficam a cargo dos oboés da caccia). De fato, na obra de Bach é possível encontrar outros exemplos desse tipo de orquestração sem baixo continuo, em árias normalmente nomeadas bassetchen. Chafe identifica o uso desse tipo de técnica orquestral em Bach com a "representação do amor e proteção de Deus aos fiéis do julgamento do pecado" (KAUFFMAN, p. 163, tradução nossa) ${ }^{210}$ e Dürr (2005, p. 185) afirma que "a ausência de baixo continuo serve como símbolo da inocência".

Nesse contexto, o uso que Bach faz da flauta transversal pode aqui traduzir em si o amor e a pureza de Jesus, que escolhe morrer pela salvação de seu povo.

A partir da segunda metade do século XVIII, a flauta transversal barroca começa a passar por mudanças em sua construção, traçando um caminho que levaria à hoje em dia chamada "flauta clássica". Resumidamente, o instrumento começou a ser construído com outras chaves além daquela usual (que em fins do século XVIII chegariam a oito ou dez), a fim de tornar a entonação de determinadas notas de sonoridade mais velada (forquilhas) mais clara e forte, o que sugere a busca por uma equalização dos sons do instrumento. Além disso, ele também passaria a ser construído de forma a privilegiar seus registros agudos e uma sonoridade, no geral, mais brilhante que aquela do instrumento barroco. Isso ocorre como um reflexo não só da ascensão do instrumento como solista à frente de grandes grupos instrumentais em grandes espaços de concertos, mas também de sua entrada definitiva na formação orquestral clássica, onde ocupará o papel do instrumento mais agudo no naipe das madeiras.

De fato, como observado por Powell,

\footnotetext{
Haydn, Mozart e Beethoven (...) raramente usaram o registro grave da flauta. Mas a escrita orquestral de fins da década de 1780 em diante cada vez mais pedia pelas habilidades da flauta no extremo oposto de sua extensão (...) Uma vez que os compositores aprenderam a escrever partes para flauta que permaneciam inteiramente acima do pentagrama os limites agudos continuaram a se expandir. As óperas de Mozart, produzidas em
}

210 "representation of God's love and protection of the faithful from the judgment of sin." 
Munique, Viena e Praga em 1781-91, frequentemente pediam pela flauta na terceira oitava, chegando ao sol3 (...) As sinfonias de Haydn para Londres (...) foram notadas como inovadoras em seu uso do registro agudo [da flauta]. (2002, p.118-9, tradução nossa) $)^{211}$

Apesar das mudanças pelas quais o instrumento passou ao longo do século XVIII, não é possível afirmar que elas o tenham transformado também como veículo alegórico. Spitzer e Zaslaw afirmam que "as flautas mantiveram suas associações pastorais por todo o século XVIII e além" (2004, p. 141, tradução nossa) 212. Por um tempo, a música perdeu a sonoridade calorosa e arredondada do registro grave da flauta transversal, tão propícia às suas antigas representações amorosas, mas mesmo assim, o instrumento, com sua suavidade e delicadeza características, parece continuar a desempenhar o mesmo papel que tomava desde a música de Lully, como mostram, por exemplos, as opiniões tardias de Grétry.

\footnotetext{
211 “Haydn, Mozart, and Beethoven (...) hardly ever used the flute's low register. But orchestral writing from the late 1780s onwards made increasing demands on the flute's abilities at the opposite extreme of its range (...) Once composers had learned to write parts for the flute that lay entirely above the treble stave the upper limits continued to rise. Mozart's operas, produced in Munich, Vienna, and Prague in 1781-91, frequently scored for the flute in the third octave as high as G3 (...) Haydn's symphonies for London (...) have been noted as innovative in their use of the high register." 212 "Flutes kept their pastoral associations throughout the eighteenth century and beyond."
} 


\subsection{0 oboé}

O oboé foi um dos instrumentos de sopro de madeira mais utilizados na orquestra ao longo dos séculos XVII e XVIII; em número de aparições, talvez mais que qualquer outro. Desde o período inicial de formação da orquestra barroca, o instrumento ali figurou e ocupou papel de extrema importância em relação à sonoridade dos grupos instrumentais. Assim como as outras madeiras, o oboé também foi utilizado em contextos alegóricos na música de diversos compositores mas, graças ao tipo de utilização orquestral ao qual se prestou desde muito cedo, seu uso como alegoria pareceu dar-se de forma diferente daquele relativo aos outros membros de sua família.

O instrumento surgiu na França, muito provavelmente na segunda metade do século XVII. Como mencionado, assim como ocorreu com outras madeiras, ele foi fruto de transformações na construção de instrumentos musicais anteriormente existentes, como as charamelas oriundas do Renascimento, a fim de apresentar-se satisfatório para a execução da música então em voga.

Haynes (2001) explica que na primeira metade do século XVII muitos instrumentos de sopro diferentes eram comumente chamados "hautbois", mostrando que o termo tinha à época uma aplicação bastante ampla e até mesmo genérica. No entanto, o instrumento que será conhecido como o típico "hautbois" barroco surgirá muito provavelmente na década de 1660, após um considerável período de experiências que levariam à sua criação. Spitzer e Zaslaw (2004, p.94, tradução nossa) narram essa questão:

Nas décadas de 1630 e 1640 hautbois eram instrumentos do tipo da charamela construídos em uma única peça de madeira, com uma ampla palheta que o intérprete acomodava dentro da boca, não entre os lábios. No final do século eles eram instrumentos como o oboé, divididos em três partes, com duas ou três chaves, e com uma palheta menor que o músico controlava com os lábios. Essa transição da charamela para "oboé barroco" provavelmente começou antes de Lully vir ao poder. Já nos dias de Mersenne, charamelas estavam sendo construídas com chaves, e intérpretes apoiavam seus lábios nas palhetas. E a transição não estava completa na época em que Lully morreu. As primeiras descrições dos oboés 
barrocos prototípicos em três partes datam de 1688, um ano após sua morte. ${ }^{213}$

De forma mais detalhada, Haynes explica sobre a situação da charamela no século XVII, e fala sobre as razões para o seu então necessário "melhoramento":

A charamela tinha atingido uma forma estável provavelmente no século XV, e seus defeitos haviam sido sanados (tanto quanto podem ser em um instrumento de sopro) em fins do século XVI. Como David Smith escreveu, 'Entre todos os sopros de madeira antigos, a família das charamelas utiliza talvez o mais engenhoso e sofisticado método de melhoria de estabilidade através da acústica do design de sua campana.' A charamela em si não precisava de um "melhoramento". O que mudou foi o contexto no qual ela funcionava, de forma que o que ela poderia fazer bem estava marginalizado na música do século XVII. No início do período, a charamela tinha perdido considerável status em relação a outros instrumentos, e vinha sendo usada com frequência cada vez menor. Foi essa situação, juntamente com novas necessidades musicais, que levaram construtores de meados do século XVII a substituir o muito satisfatório design da charamela com um experimento que eventualmente estabilizou-se na forma do oboé [hautboy]." (2001, p. 18 , tradução nossa) $)^{214}$

\section{Continuando a falar da charamela e de suas transformações seiscentistas, o autor também comenta as características da música barroca que exigia de todos os instrumentos musicais um novo potencial expressivo:}

Uma das maiores conquistas da charamela estava no fato de que era o prototípico instrumento de consort; como aponta Peter Holman, 'ela foi

\footnotetext{
213 "In the 1630s and 1640s hautbois were shawm-like instruments constructed from a single piece of wood, with a broad reed that the player placed inside his mouth, not between his lips. By the end of the century they were oboe-like instruments, divided at three joints, with two or three keys, and with a narrower reed that the player controlled with his lips. This transition from shawm to "Baroque oboe" problably began before Lully came to power. Already in Mersenne's day, shawms were being built with keys, and players were putting their lips on their reeds. And the transition was not complete by the time Lully died. The earliest descriptions of three-joint, prototypical Baroque oboes date from 1688, the year after his death."

214 "The shawm had reached a steady form problably by the fifteeth century, and bugs had long since been worked out of it (as much as they can be on a woodwind) by the end of the sixteenth century. As David Smith wrote, 'Among all the early woodwinds, the family of shawms employs perhaps the most ingenious and sophisticated method for improving stability through the acoustics of its bell design.' The shawm in itself had no need of 'improvement'. What changed was the context in which it functioned, so that what it could do well was marginalized in the music of the seventeenth century. By the beggining of that century, the shawm had lost considerable status to other instruments, and was being used less and less frequently. It was this situation, along with new musical necessities, that led mid-seventeenthcentury makers to replace the quite satisfatory design of the shawm with an experiment that eventually stabilized in the form of the hautboy."
} 
quase certamente o primeiro instrumento a ser feito em mais de um tamanho correspondente'. Mas o que era pedido da charamela em meados do século XVII - e o que ela não poderia fazer sem que sua forma fosse modificada - era expressar afetos. Ao invés de deitar uma ampla faixa de som através de um grupo de instrumentos similares como uma banda de charamelas, era pedido que se tocasse sozinho em imitação de um cantor solista, a fim de expressar a força emocional dos textos (reais ou imaginados), 'falar' trazendo à tona o significado das palavras, e tocar os ouvintes. (2001, p. 18-19, tradução nossa) $)^{215}$

Claramente, a charamela, desenvolvida para um tipo de música voltada à produção de sonoridade forte e incisiva (como aquela para ser tocada ao ar livre, em procissões, cortejos, festas, etc) não possuía o refinamento e capacidade de nuances necessárias à execução daquela nova música retórica e eloquente. Nesse contexto, o oboé surge como um novo e forte meio musical, considerado expressivo o bastante para a imitação da voz:

A voz solista era a ferramenta primária usada para a expressão das emoções e, ao cantar, intensificar o significado das palavras. Como o epítome do instrumento musical, servia como modelo para outros instrumentos que tocassem sozinhos, 'falando' como indivíduos. Diderot observou que, uma vez que a voz era sem dúvida o melhor 'instrumento' para transformar afetos em som, ele considerava os melhores instrumentos aqueles que eram os mais apropriados 'para acompanhar e imitar as habilidades do cantor. É por essa razão que o oboé tem um dos primeiros lugares'. Discutindo boa dicção em seu tratado de canto de 1723, Tosi sugeriu que o hautboy era como uma voz sem palavras. Escreveu: 'Pois se as palavras [do cantor] não são ouvidas para serem entendidas, não haverá grande diferença entre uma voz humana e um oboé.' (HAYNES, 2001, p. 19-20, tradução nossa)216

\footnotetext{
215 "One of the great achievements of the shawm was that it was the prototypical consort instrument; as Peter Holman (pers. comm.) points out, 'it was almost certainly the first instrument to be made in more than one matched size'. But what was demanded of the shawm by the mid-seventeenth century - and what it could not do without changing its form - was to express affections. Rather than lay down a broad swath of sound through a group of similar instruments like a shawm band, it was asked to play alone in imitation of a solo singer, to express the emotional force of the texts (real or imagined), to 'speak' by bringing out the meaning of words, and to move listeners."

216 "The solo voice was the primary tool used for expressing emotions and, by singing, intensifying the meaning of the words. As the epitome of the musical instrument, it served as a model for the other single instruments playing alone, 'speaking' as individuals. Diderot remarked that, since the voice was without question the best 'instrument' for transforming affects into sound, he considered those instruments best that were most appropriate 'at accompanying and imitating the infinite abilities of the singer. It is for this reason that the hautboy ranks among the first'. Discussing good diction in his treatise on singing of 1723, Tosi implied that an hautboy was like a voice without words. He wrote: 'For if the words [of the singer] are not heard so as to be understood, there will be no great Difference between a human voice and a Hautboy'."
} 
Foi necessário um tempo para que o novo oboé se estabilizasse em sua forma e possibilidades musicais, sendo que Haynes aponta o período entre os anos de 1664 e 1670 como o de desenvolvimento do instrumento. De qualquer modo, a partir dessa época ele ganharia cada vez mais popularidade na França e também em outros importantes centros da Europa. Baines (1991, p. 278-279, tradução nossa), comenta que

desde o início o oboé foi um sucesso, e conforme se tornou rapidamente conhecido em outros países parece ter impressionado músicos principalmente através da esplêndida extensão expressiva de seu som. ${ }^{217}$

De fato, o oboé possuía as características necessárias à interpretação da música barroca e isso parece ter sido logo percebido e aclamado. Já em 1668, o Abade de Pure faz comentários sobre o instrumento e, apesar de criticar o domínio de suas possibilidades técnicas como ainda não completamente alcançado (a execução ao instrumento apresentava falhas), o autor tece claros elogios a ele, principalmente em relação a seu valor expressivo:

Oboés têm um som elevado, e, tocados como são hoje em dia na Corte e em Paris, deixam pouco a ser desejado. Eles fazem cadências tão bem afinadas, trilos tão doces, e diminuições tão regulares como a voz mais bem treinada e o mais perfeito instrumento. Nós temos visto seu sucesso no palco e em certas cenas específicas. Eu não tenho dúvidas de que eles teriam um efeito maravilhoso em uma Pastorale." (1668, p. 274, tradução nossa) $)^{218}$

Conforme os problemas técnicos do instrumento apontados pelo abade foram sendo sanados, ter-se-ia o oboé como um dos sopros mais interessantes e completos do período, em que

\footnotetext{
217 "From the first the oboe was a success, and as it quickly became known in other countries it seems to have impressed musicians above all through the splendid expressive range of its sound."

218 "Les Haut-bois ont un chant plus élevé, \& de la maniere dont on en Joüe maintenant chez le Roy, \& à Paris, il y auroit peu de choses a en desirer. Il font les cadences aussi Justes, les tremblements aussi doux, \& les diminutions aussi regulieres que les voix les mieux instruites, \& que les instruments les plus parfaits. Nous en avons mesme veu le succez sur les tres, $\&$ en certaines Entrées particulieres: le ne doute point quils ne fissent un merveilleux effet dans une Pastoralle."
} 
o controle direto da palheta produziu um instrumento cuja habilidade especial era expressar pequenos gestos musicais intensos, fazer rápidas e extremas mudanças de dinâmica, inícios e finalizações frequentes, e um contraste tonal impressionante entre as notas e dentro das notas - um oboé 'eloquente'. (HAYNES, 2001, p. 20, tradução nossa) $)^{219}$

A partir das características apresentadas, fica compreensível o "apelido" dado ao instrumento por Mattheson, em 1713.

O já mencionado sucesso do oboé levou-o para outros locais muito rapidamente:

[Em 1668], o instrumento era desconhecido fora da França. Mas quase imediatamente ele se popularizou em todos os lugares: em 1673, estava sendo tocado em Londres, em 1677 em Turim, Amsterdã e Haia, Madri em 1679 , Celle e Sttutgart em 1680, Bruxelas na década de 1680, e Veneza e Viena por volta de 1690 (...) No final do século XVII, havia poucos locais de poder político na Europa onde o oboé não era conhecido e não estava estabilizado. (HAYNES, 2001, p. 121, tradução nossa) 220 $^{220}$

Graças às suas possibilidades técnico-expressivas, o oboé foi introduzido na orquestra, junto das cordas. A figura de Lully é mais uma vez importante nesse processo, já que o compositor teria sido um dos primeiros a utilizar o instrumento com frequência, dando a ele papéis específicos junto ao conjunto instrumental. Haynes (2001, p. 20, tradução nossa) explica:

O novo oboé foi desenvolvido especificamente para uso nas produções de Lully, então esperava-se que fosse um tipo de instrumento de sopro paralelo ao violino, capaz de mesclar-se a outros instrumentos e usar uma extensão de duas oitavas centrada nas notas usuais do violino, com escalas fáceis de dó e ré maior. ${ }^{221}$

219 "Direct control of such a reed produced an instrument whose special ability was to express short intense musical gestures, to make quick and extreme changes of dynamics, frequent starts and stops, and striking tonal contrast between notes and within notes - an 'eloquent' oboe."

220 "At this date, the instrument was unknown outside France. But almost immediately it caught on everywhere else: by 1673 it was being played in London, by 1677 in Turin, Amsterdam, and the Hague, Madrid in 1679, Celle and Stuttgart in 1680, Brussels in the 1680s, and Venice and Vienna by the 1690s (...) By the end of the century, there were few places of political power in Europe where the hautboy was not familiar ans established."

221 "The new hautboy was developed specifically for use in Lully's productions, so it was expected to be a kind of wind parallel to the violin, able to blend with other instruments and use a two-octave range centred on the usual notes of the violin, with easy scales in C and D major." 
Lully deu ao oboé funções distintas em meio ao grupo orquestral, que passavam pela execução de eventuais solos e trechos em trio (com um segundo oboé e um fagote, cujo modelo barroco também foi introduzido na orquestra na mesma época). No entanto, foi especialmente significativa a introdução lulliana de um tipo de orquestração na qual violinos e oboés tocavam as mesmas partes, em uníssono. Esse modo de unir a sonoridade de ambos os instrumentos criou uma cor sonora única e especial, essencialmente barroca, que foi amplamente utilizada por praticamente todos os compositores do período (tanto no século XVII como no XVIII), de uma forma ou de outra, tornando-se extremamente característica e uma espécie de instituição musical do Barroco. Outros instrumentos (como as flautas) também foram utilizados em uníssono com violinos, mas de forma mais pontual e específica, enquanto que violinos mesclados a oboés tornou-se uma sonoridade predominante:

\begin{abstract}
Na música orquestral, o padrão estabelecido por Lully se manteve popular em toda a Europa através da primeira metade do século XVIII: uma orquestra de cordas básica, frequentemente suplementada com oboés e fagotes dobrando as cordas, reforçando-as e variando a cor, e tocando ocasionalmente passagens expostas em 'trio'. (...)

Dobrar um grupo de cordas com oboés trazia ao grupo um maior caráter de 'tutti'; adicionava pungência e claridade, e mudava a cor da linha, 'dando plenitude e contorno a um grande ripieno, fornecendo brilho para a coloratura em passagens virtuosas através de seu rápido ataque nas primeiras e últimas notas', como Harnoncourt observou. Palhetas duplas eram provavelmente adicionadas a muitas partituras nas quais sua presença não era mencionada no papel. Muitas grandes obras possuem breves indicações como 'con strom.', que podem ou não ter incluído oboés. (HAYNES, 2001, p. 280, tradução nossa) $)^{222}$
\end{abstract}

Tratando desse assunto, ao falar dos oboés na obra de Charpentier, Duron explica:

\footnotetext{
222 "In orchestral music, the pattern established by Lully remained popular all over Europe through the first half of eighteenth century: a basic string orchestra, often supplemented with hautboys and bassoons doubling the strings, strengthening them and varying the colour, and playing occasional exposed 'trio' passages. (...) Doubling hautboys to a string band gave a more 'tutti' character; it added bite and clarity, and changed the colour of the line, 'giving fullness and contour to a large ripieno, providing brilliance to the coloratura in virtuoso passages by their prompt attack on first and last notes', as Harnoncourt put it. Double reeds were problably added to many scores in which their specific presence is not mentioned on paper. Many larger works have brief indications like 'con strom.', which may or may not have included hautboys."
} 
Se as flautas aparecem frequentemente nos manuscritos de Charpentier, é provavelmente em grande parte devido à ambiguidade do termo: ele faz referência a dois grupos distintos [flautas doce e transversal]. O problema não existe no caso das palhetas duplas. Sua presença é assinalada apenas nas passagens originais, mas esses instrumentos são provavelmente muito mais solicitados do que aparece nas partituras (...)

Contrariamente ao que faz com as flautas, Charpentier não utiliza toda a família de instrumentos, mas apenas os 'dessus de hautbois'. (1986, p. 47, tradução nossa) $)^{223}$

Levando-se essas questões em consideração, é possível concordar que o mais frequente papel do oboé na orquestra barroca tenha sido efetivamente o de dobrar a linha dos violinos e, estando essa função consumada, os compositores não se viam na obrigação de sempre indicá-la na partitura, uma vez que ela seria automaticamente assim executada pelos grupos instrumentais. Nesse contexto, não pareceria errôneo afirmar que o oboé seria um dos instrumentos com maior repertório em meio à música barroca, sendo que sua constante presença em composições muitas vezes não precisaria nem mesmo ser indicada.

223 "Si les flûtes apparaissent fréquemment dans les manuscrits de Charpentier, c'est probablement en grande partie à cause de l'ambiguïté du terme: il fait référence à deux groupes distincts. Le problème ne se pose pas pour les anches doubles. Leur présence est signalée seulement dans des passages originaux, mais ces instruments ont probablement beaucoup plus sollicités qu'il n'y paraît dans les partitions. (...) Contrairement à ce qu'il fait pour les flûtes, Charpentier n'emploie pas toute la famille instrumentale, mais les seuls <<dessus de hautbois >>." 


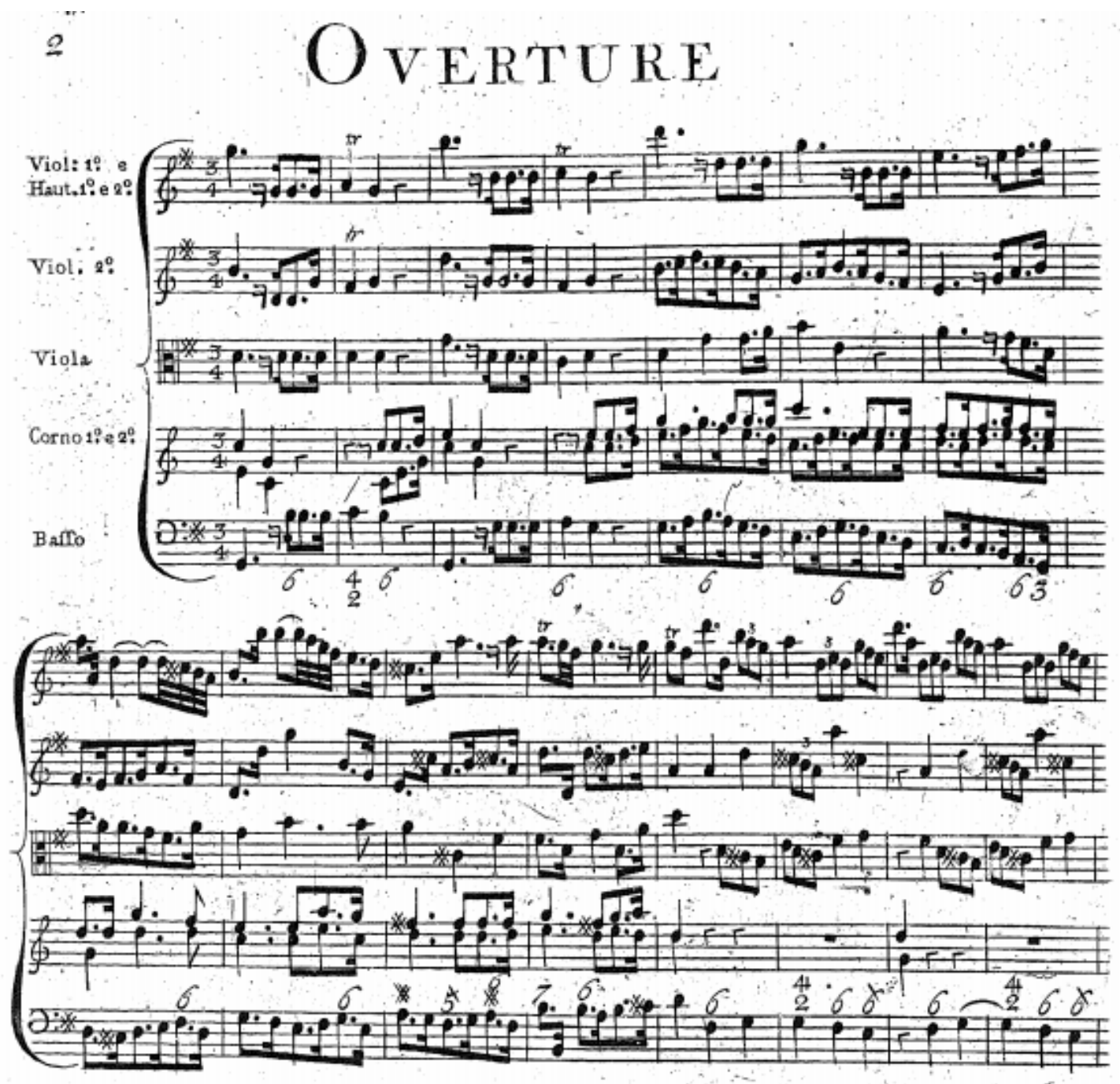

Fig. 46 - Overture do oratório Samson HWV 57 (1741) de Handel, um dos muitos exemplos setecentistas da recorrente orquestração na qual os oboés dobram as partes de violino, em uníssono

Do ponto de vista alegórico, o oboé parece ter sido vislumbrado como um herdeiro do tradicional símbolo do pastoral associado a seus parentes anteriores usando palhetas duplas e por vezes utilizado nesse contexto desde Lully. Haynes detalha:

Assim como outros instrumentos de sopro, 'hautbois' eram regularmente usados nas partituras de Lully para evocar uma atmosfera pastoral. Eles frequentemente descreviam a vida de um pastor mítico: pacífica, inocente e sem problemas, evocando natureza idílica. A imagem bucólica do oboé mesclou-se àquela da flauta, que era o principal instrumento do Amour. Dentro do tema pastoral, no entanto, quando a paz ao invés do amor era o 
sujeito, seriam os oboés os instrumentos utilizados. (2001, p. 126, tradução nossa) $)^{224}$

A obra de Rameau dá exemplos interessantes da aplicação alegórica do oboé, como explanado por Sadler (1981-82, p. 57-58, tradução nossa):

O oboé foi usado por Rameau, assim como pela maioria de seus contemporâneos, menos como um instrumento solista do que como um reforço dos violinos. Comparado com a flauta, passagens independentes para oboé tendem a ser poucas e, nas primeiras óperas, mais breves. $\mathrm{Na}$ década de 1730, a extensão dessa independência é muito mais dependente do número de cenas envolvendo pastores, caçadores, marinheiros e similares. Em Castor et Pollux, que carece inteiramente de cenas como essas, a escrita independente para o oboé é limitada a curtas passagens do 'trio de hautbois' na abertura, chacona e em poucos outros exemplos. Hippolyte et Aricie, na qual todos os personagens acima aparecem, tem muito mais: há sete movimentos nos quais os oboés são inteira ou largamente independentes e outros quatro nos quais têm poucas mas importantes passagens em obbligato. Esse é ainda um número pequeno comparado aos 17 nos quais eles meramente dobram os violinos. ${ }^{225}$

Como se vê, os oboés são alegoricamente usados por Rameau também em contextos circundando o pastoral e outras paisagens naturais ou rústicas.

\footnotetext{
224 “Like other wind instruments, 'hautbois' were regularly called on in Lully's scores to evoque a pastoral atmosphere. They often depicted a mythical shepherd's life: peaceable, innocent, and untroubled, evoking idyllic nature. The hautboy's bucolic image shaded into that of the flute, which was the principal instrument of Amour. Within the pastoral theme, however, when peace rather than love was the principal subject, it was hautboys that were called for."

225 "The oboe was used by Rameau, as by most of his contemporaries, less as a solo instrument than as a reinforcement of the violins. Compared with the flute, independent passages for oboe tend to be both fewer and, in the earlier operas, briefer. In the 1730s, the extent of this independence is very much dependent on the number of scenes involving shepherds, huntsmen, sailors and suchlike. In Castor et Pollux, which lacks such scenes entirely, independent oboe writing is limited to short 'trio des hautbois' passages in the overture and chaconne and little else. Hippolyte et Aricie, in which all the above characters appear, has many more: there are seven movements in which oboes are entirely or largely independent and a further four in which they have short but important obbligato passages. This is still a small number compared with the 17 in which they merely double the violins."
} 


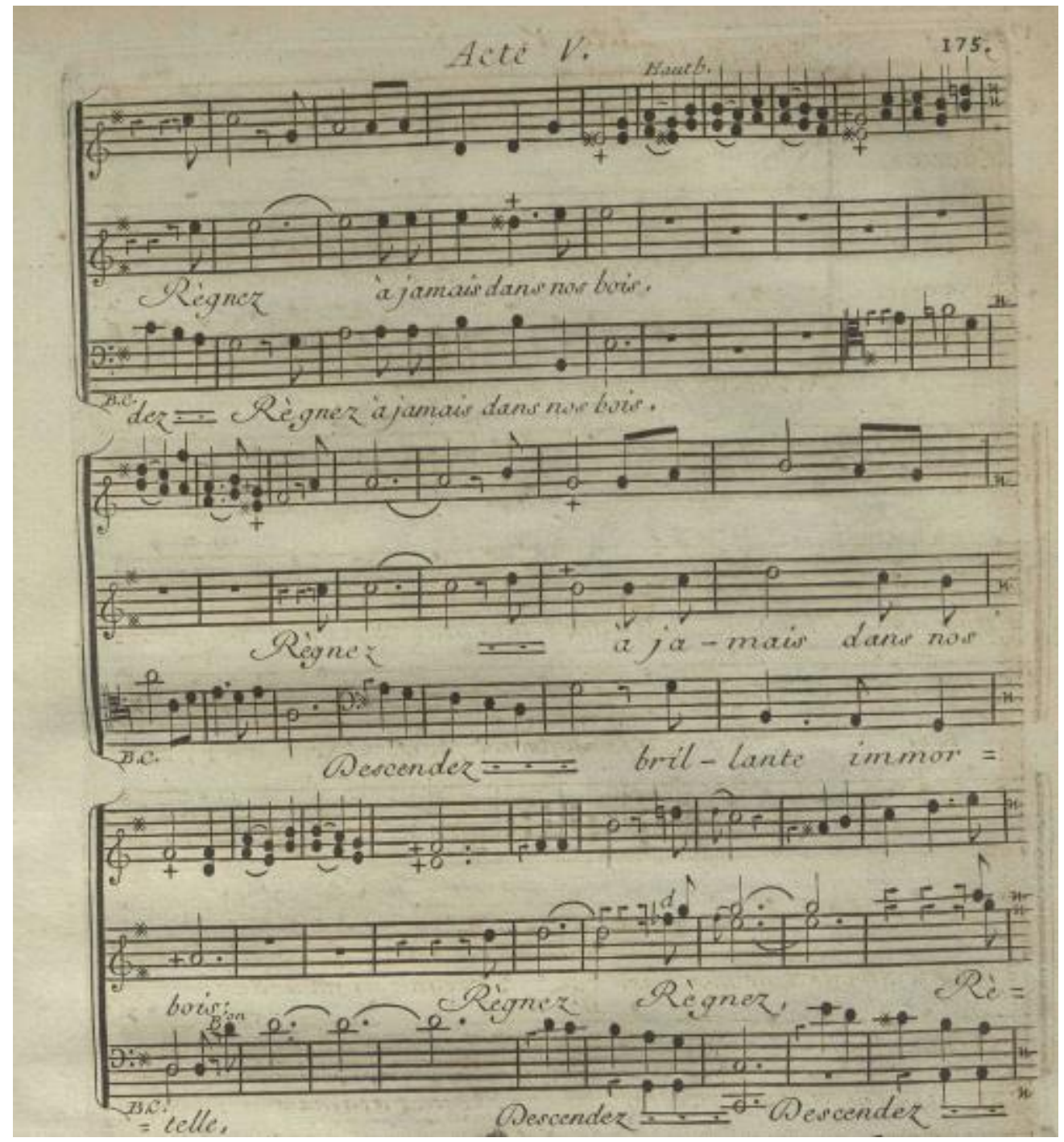

Fig. 47 - Excerto do coro de pastores no quinto ato de Hippolyte et Aricie, de Rameau (1733), no qual os oboés fazem intervenções solísticas, certamente por seu viés alegórico ligado ao tema pastoral e campestre

Spitzer e Zaslaw comentam sobre o uso alegórico dos sopros na ópera barroca, apontando também o caminho diferente através do qual o oboé foi direcionado, graças às suas então funções orquestrais:

Os instrumentos de sopro também começaram a juntar-se aos acompanhamentos das árias no fim do século XVII. Trompetes, que nos estereotípicos conjuntos marciais do intermédio e da ópera cortesã haviam tocado fanfarras e sinfonias para cenas de batalha, agora por vezes acompanhavam árias junto das cordas (...) Oboés e flautas, como os trompetes, juntaram-se ao acompanhamento de árias inicialmente por suas associações extramusicais, nesse caso pastorais e rústicas (...) Os oboés, no entanto, logo perderam seu papel estereotípico. Compositores começaram 
a utilizá-los para reforçar as partes de violino ou dar contraste a seu som. Os oboés também encontraram um novo papel em árias expressando emoções fortes. Se em meados do século XVII a adição de acompanhamento de cordas tinha sido o bastante para marcar um ária como especial, no século XVIII esse acompanhamento tinha se tornado rotina, e coube ao pathos de um instrumento de sopro sugerir o mesmo nível de emoção. (2004, p. 141, tradução nossa) $)^{226}$

Percebe-se, assim, que o tão comum papel do oboé como dobra frequente do violino o teria afastado de seu potencial uso alegórico. Ora, os outros instrumentos de sopro continuaram em sua maioria sendo normalmente usados pontualmente na música barroca, conservando sua participação como "efeito especial" em uma obra, com suas cores sonoras sendo ouvidas em momento específicos, o que sublimava suas possibilidades catárticas e alegóricas. Já o oboé teve suas cores alocadas como parte integrante de uma sonoridade mais comum, ainda que importantíssima, no Barroco, o que pode ter contribuído para a diminuição da concepção de seu som como sendo "exclusivo" ou "supreendente" para o público. Não obstante, como visto, seu uso alegórico não desapareceu, o que indica que os compositores ainda o entendiam como potencialmente efetivo.

É possível comparar-se o uso barroco comum do fagote com aquele do oboé, uma vez que o instrumento também foi desde muito cedo utilizado para dobrar outras linhas, no caso, as do baixo continuo. No entanto, o fagote pode ter sido alegoricamente vislumbrado de outra forma, uma vez que seus potenciais extramusicais parecem ter sido utilizados de forma mais ampla e variada, como se verá no capítulo seguinte.

O oboé continuou a ser usado de forma efetiva graças à sua intensa expressividade. Sendo um bom representante de "fortes emoções", ele se prestou a uma infinita variedade de affetti, o que também dificulta atribuir a ele uma provável

\footnotetext{
226 "Wind instruments too began to join aria accompaniment in the late seventeeth century. Trumpets, which in the stereotyped martial ensembles of intermédio and court opera had played fanfares and symphines for battle scenes, now sometimmes accompanied arias along with the strings (...) Oboes and flutes, like trumpets, joined aria accompaniment initially for their extra-musical associations, in this case pastoral and rustic (...) Oboes, however, soon shed their stereotypical role. Comosers began to use them to reinforce the violin parts or to provide contrast to the violin sound. Oboes also found a new role in arias expressing string emotions. Whereas in the mid-seventeenth century the addition of string accompaniment had been enough to mark an aria as special, by the eighteenth century string accompaniment had become routine, and it took the pathos of wind soloists to suggest the same level of emotion."
} 
conexão alegórica mais forte e direta com algum afeto ou emoção específica (apesar dos tratados vistos anteriormente apresentarem tendência a associá-lo, de forma geral, a sentimentos alegres). O oboé apresentava-se muito versátil e completo como instrumento musical, como sublinhado por Baines (1991, p. 279, tradução nossa):

Ao trompete eram dadas árias de caráter brilhante e alegre; às flautas, aquelas de tipo 'lânguido e melancólico'; mas o novo oboé, assim como a voz humana e o violino, podia abranger qualquer estado de espírito. ${ }^{227}$

A obra de J. S. Bach é talvez o maior e melhor exemplo barroco do uso do oboé para expressar uma ampla gama de emoções humanas, em toda sua beleza e variedade. Haynes (2001, p. 360, tradução nossa) comenta que

\begin{abstract}
Bach deu ao oboé mais solos em suas obras vocais do que a qualquer outro instrumento (...) O repertório do oboé barroco inclui mais solos de Bach do que de qualquer outro compositor. Não há necessidade de dizer que essa música é da mais alta qualidade, fazendo dele o maior conjunto de composições para o instrumento que sobrevive. ${ }^{228}$
\end{abstract}

Em meados do século XVIII, com o despontar das ideias iluministas que contribuirão para a disseminação de novas concepções artísticas e que na música resultarão no início do período dito "galante", o uso dos instrumentos de sopro na orquestra passará por transformações, através das quais eles começarão a exercer papéis diferentes dos anteriores. Nesse contexto, o colla parte constante dos sopros junto às cordas será aos poucos abandonado em prol de uma textura instrumental mais simples e de maior leveza. Assim, a tão comum sonoridade barroca de violinos e oboés em uníssono começará a sair de moda. No entanto, o oboé continuará a ser um dos sopros de madeira mais requisitados pelos compositores, como exemplificam Spitzer e Zaslaw (2004, p. 311, tradução nossa):

\footnotetext{
227 "To the trumpet were allotted airs of joyous and brilliant character; to the flutes, those of the 'languishing and melancholy' kind; but the new oboe, like the human voice and the violin, could encompass every mood."

228 "Bach gave the hautboy more solos in his vocal works than any other instrument (...) The hautboy's repertoire includes more solos by Bach than by any other composer. It hardly needs to be said that this music is of consistently high quality, making it the largest single body of important compositions for the instrument that survives."
} 
Por volta de 1750 a maioria das sinfonias publicadas em Paris, Londres e Amsterdã eram orquestradas para cordas em quatro partes mais dois oboés e duas trompas, sugerindo que trompas e oboés estavam disponíveis na maioria das orquestras. Essa orquestração a 8 , que poderia acomodar flautas alternando com oboés bem como fagotes tocando junto da linha de baixo - permaneceu padrão para sinfonias publicadas até a década de 1780. ${ }^{229}$

De fato, o par de oboés, junto do par de trompas, é o conjunto de sopros mais comum nas obras de muitos compositores do período, incluindo os filhos de Bach, Gossec, os Stamitz, os Benda, além de Haydn e Mozart em suas fases iniciais. Na futura orquestra clássica, o oboé terá um lugar mais do que garantido, desempenhando papel importante entre os sopros do conjunto.

Como veículo alegórico, o oboé parece ter continuado a ser vinculado sobretudo ao pastoral e ao "campestre" durante todo o século XVIII, como mostram as opiniões dos tratadistas do capítulo 5.2. No entanto, sua versatilidade expressiva permitiu que seguisse como bom representante de diferentes emoções e afetos, apresentando-se como um multi-facetado - e eloquente - orador musical.

229 "By the 1750s most symphonies published in Paris, London, and Amsterdam were scored for four string parts plus two oboes and two horns, suggesting that horns and oboes were available in most orchestras. This à 8 scoring, which could accomodate flutes alternating with oboes as well as bassoons playing along on the bass line - remained standard for published symphonies until the 1780s." 


\title{
5.6 A clarineta (e o chalumeau)
}

Apesar de fazer parte da ampla família dos instrumentos de sopro de madeira, a clarineta apresenta algumas características únicas que a diferenciam das flautas, do oboé e do fagote. Do ponto de vista de sua construção, ela mostra-se singular por constituir-se como um instrumento de corpo cilíndrico que funciona como um "tubo fechado", o que Ihe dá possibilidades únicas, como um registro fundamental particularmente grave em relação ao seu tamanho. O tubo fechado ainda faz com que os sons da clarineta comportem-se de maneira distinta daquela relativa às outras madeiras, o que se reflete muito diretamente no fato do instrumento ter seu registro médio e agudo formado por harmônicos originados em intervalos de décima segunda, ao invés da mais comum oitava presente nos outros instrumentos. Além disso, ela também se diferencia pelo uso da palheta-simples, o que lhe confere um timbre resultante muito diferente de seus familiares utilizando palhetas-duplas.

Do ponto de vista histórico, a clarineta também se diferencia em relação às suas origens. Enquanto as outras madeiras têm sua forma barroca fortemente ligada à França, a clarineta é certamente uma invenção mais recente e do território alemão.

Em 1730, em um documento tratando do estado das artes e da matemática na cidade de Nüremberg, J. C. Doppelmayr escreve o seguinte texto, considerado dos mais importantes no que concerne as origens da clarineta:

\begin{abstract}
E finalmente ele foi ainda guiado para mais adiante por sua afinidade com a arte, como é repetidamente mostrado por sua invenção e melhoria dos referidos instrumentos, essa boa intenção realmente atingiu o efeito desejado, uma vez que no início do presente século, ele inventou um novo tipo de instrumento de sopro, a chamada clarineta, para o grande deleite dos amantes da música, ademais ele aprimorou o Stock ou Rackett-Fagote que já era conhecido nos tempos antigos, e finalmente também apresentou chalumeaux aperfeiçoados. (KARP, 1986, p. 545, tradução nossa) ${ }^{230}$
\end{abstract}

\footnotetext{
230 "And finally he was driven by his affinity for the art yet further, as is repeatedly shown by his invention and improvement of the forementioned instruments, this good intention really did attain a desired effect, in that at the beggining of this present century, he invented a new kind of wind instrument, the so-called clarinet, to the great delight of music lovers, furthermore he improved the stock- or rackett-bassoons which were already known in the olden days, and finally also presented the improved chalumeaux."
} 
As afirmações de Doppelmayr referem-se à figura de Johann Christoph Denner, famoso luthier radicado em Nüremberg no final do século XVII, a quem muitas das vezes é atribuída a invenção da clarineta. O documento de Doppelmayr é, no entanto, tendencioso e, como afirma Lawson (1979, p. 351, tradução nossa), contém incorreções e não deve ser lido sem crítica, uma vez que "é esperado do autor que o mesmo enumere as realizações de um artesão progressista local ao invés das de artesãos contemporâneos de outros lugares" ${ }^{231}$. De qualquer modo, J.C. Denner e seu filho Jakob são hoje aceitos como os mais prováveis responsáveis pelos citados instrumentos, ainda que o trabalho dos ateliers de outros artesãos como Oberländer e Kelmer também seja importante nesse aspecto.

Mesmo tendo sido a clarineta o instrumento de origem barroca que se manteve no cenário musical, alcançando um posto importante na orquestra sinfônica e permanecendo significativamente até os dias de hoje, ao tratar-se do século XVIII é interessante dividir o foco do instrumento com outro de seu parentesco, o já mencionado chalumeau, uma vez que por grande parte do período este permaneceu sendo interessantemente utilizado ao mesmo tempo que a clarineta, acumulando um repertório de valor expressivo que não deve ser menosprezado. Além disso, em relação ao seu uso alegórico no século XVIII, o chalumeau e a clarineta traçaram um caminho singular que vai de uma oposição à apropriação, como será discutido. 0 diferente aspecto alegórico envolvendo esses instrumentos de relação próxima é refletido nos comentários de Lawson: "A relação entre os dois instrumentos é particularmente incomum porque as muitas similaridades físicas não estão refletidas em seus papéis musicais" (1979, p. 351, tradução nossa) ${ }^{232}$ e "as fontes teóricas e musicais dão evidência clara de que o chalumeau e a clarineta foram vistos como instrumentos separados e distintos ao longo do século XVIII." (1986, p. 554, tradução nossa) $)^{233}$

O termo chalumeau foi, anteriormente ao século XVIII, usado inúmeras vezes e em muitas variantes para designar uma série de instrumentos distintos, normalmente

\footnotetext{
231 "the author might well be expected to enumerate the achievements of a progressive local craftsman rather than of contemporary craftsmen elsewhere."

232 "The relationship between the two instruments is particularly unusual because the many physical similarities are not reflected in their respective musical roles."

233 "theoretical and musical sources provide clear evidence that chalumeau and clarinet were regarded as separate and distinctive instruments throughout the 18th century."
} 
pequenos e simples instrumentos de sopro, fazendo ou não uso de palhetas. Não obstante, as fontes setecentistas, mesmo utilizando nomenclaturas diversas (Hoeprich, 2008 p. 45, cita vinte variantes) normalmente referem-se a um mesmo tipo de instrumento, o chalumeau, que teria sido inventado por Denner.

Rice (1992, p.38, tradução nossa) afirma que "o chalumeau de palheta-simples do fim do século XVII e do XVIII foi construído em uma variedade de tamanhos e afinações com uma, duas, três, cinco ou sete chaves, ou ainda com nenhuma." ${ }^{234}$ De qualquer modo, um modelo específico, o de duas chaves, tornou-se o mais conhecido. Lawson discorre sobre a urgência da criação desse tipo de chalumeau, bem como de suas principais características:

A informação disponível (...) indica que o chalumeau usado por compositores do século XVIII evoluiu na tentativa de se aumentar o volume de som que a flauta doce produzia, dando a ela uma palheta-simples e um bocal. Fontes musicais mostram que os quatro tamanhos de chalumeau listados por J. F. B. C. Majer em seu Museum Musicum (Nurembergue, 1732) correspondem em tamanho às flautas doces sopranino, soprano, contralto e tenor, soando uma oitava abaixo devido às propriedades acústicas do tubo cilíndrico fechado [do qual eram feitos os instrumentos]. A adição de duas chaves diametralmente opostas tornou possível a extensão fundamental de uma décima-primeira, que as proporções do bocal e da palheta eram especialmente desenhadas para produzir; uma ou duas notas de harmônicos superiores eram por vezes pedidas pelos compositores e mais notas eram frequentemente possíveis." (1979, p. 351, tradução nossa) ${ }^{235}$

Grosso modo, o aspecto do chalumeau era o de uma flauta doce dotada de bocal de clarineta e de duas chaves localizadas acima dos furos do corpo do instrumento, uma na frente e outra, na mesma direção, atrás.

Uma das principais características do instrumento era o fato de ter disponíveis, a princípio, apenas as notas fundamentais (apesar de, como visto, alguns harmônicos

\footnotetext{
234 "The single-reed chalumeau of the late seventeenth century and eighteenth century was built in a variety of sizes and tunings with one, two, three, five, or seven keys, or none at all."

235 "The available evidence (...) indicates that the chalumeau used by 18th-century composers evolved in attempts to increase the volume of sound the recorder produced, by furnishing it with a single reed and mouthpiece. Musical sources show that the four sizes of chalumeau listed by J. F. B. C. Majer in his Museum Musicum (Nuremberg, 1732) correspond in length to sopranino, descant, treble and tenor recorders, sounding an octave lower on account of the acoustical properties of the cylindrical stopped pipe. The addition of two diametrically opposed keys made available a fundamental range of an eleventh, which the proportions of mouthpiece and reed were principally designed to produce; one or two overblown notes were sometimes demanded by composers and more were often possible."
} 
serem possíveis), o que limitava consideravelmente sua extensão. Esse fato explica o motivo do instrumento ser confeccionado em famílias com soprano, alto, tenor e baixo (mesmo em uma época na qual os consorts de instrumentos já não estavam mais tanto em voga) a fim de haver a possiblidade de obter-se a mesma sonoridade em uma maior extensão.

É provável que o chalumeau tenha antecedido a clarineta, cronologicamente. Lawson reforça que "o chalumeau parece ter existido por dez ou quinze anos antes da primeira documentação da clarineta" e que "se há alguma significância na data de 1690 tradicionalmente atribuída à 'invenção' da clarineta, ela certamente se relaciona com a evolução do chalumeau."(1979, p. 351, tradução nossa) $)^{236}$

A sonoridade inusitada e predominantemente aveludada do chalumeau certamente representou um novo e promissor adendo à palheta de timbres de instrumentos de sopro de madeira conhecidos até então. Já no início do século XVIII, o instrumento começou a ser utilizado na música dramática, na qual é possível perceber o tipo de papel alegórico que desempenharia mais frequentemente.

Na Viena do período, o chalumeau parece ter sido contemplado desde o começo como uma excelente ferramenta expressiva para os compositores, e foi usado de forma especialmente prolífica, como comenta Hoeprich (2008, p. 52, tradução nossa):

Nas primeiras décadas do século XVIII, o chalumeau desfrutou de grande popularidade na corte dos Habsburgo (muito dessa música, em quantidade que excede o número de quarenta óperas e oratórios, está hoje preservada nas bibliotecas de Viena). Até mesmo o Imperador José I compôs uma parte obbligato para um chalumeau soprano, na Chilonida de M. A. Ziani (1709). ${ }^{237}$

O autor continua descrevendo características do uso alegórico do instrumento:

\footnotetext{
236 "The chalumeau appears to have existed for ten or fifteen years before the first documentation of the clarinet."; "If there is any significance at all in the date of 1690 traditionally assigned to the 'invention' of the clarinet, it surely relates rather to the evolution of the chalumeau."

237 "in the first decades of the eighteenth century, the chalumeau enjoyed great popularity at the Hapsburg court. (Much of this music, in excess of forty operas and oratorios, is preserved today in Vienna's libraries.) Even the Emperor Joseph I composed an obbligato part for a soprano chalumeau, in M. A. Ziani's Chilonida (1709)."
} 
O público frequentador de concertos estava evidentemente cativado por esse novo som e a habilidade com a qual esses compositores escreviam para ele. O tema das árias invariavelmente trata das vicissitudes do amor, e a ambientação é frequentemente pastoral - cenários que exploram a cor sutil e sedutora do instrumento bem como sua gama de dinâmica e flexibilidade. A música frequentemente inclui a indicação affetuoso ou cantabile, e o instrumento é pareado com outros suaves e doces como as flautas transversal e doce e as violas d'amore e da gamba. ${ }^{238}$

Essas características da música escrita para o chalumeau apontadas por Hoeprich não serão exclusividade das obras vienenses. De forma geral, o instrumento será sempre tratado através desse viés alegórico. Essencialmente, é usado para música delicada e lírica e isso se dará não só no gênero dramático-vocal, mas de certo modo também na música puramente instrumental. Dessa forma, o chalumeau teria tomado para si significações alegóricas semelhantes às da flauta doce, dando a elas, porém, um diferente sabor.

Dentre os compositores residentes em Viena que se destacam no uso do chalumeau estão os irmãos Bononcini e J. J. Fux, que viriam a influenciar outros como Caldara e Conti.

Crawford (2008), tratando da música vienense para soprano e chalumeau soprano, analisa árias dos compositores acima mencionados nas quais o instrumento tem um papel obbligato junto da voz. Nas obras de onde provêm as árias analisadas, de inspiração sacra ou secular, o chalumeau é utilizado como um efeito especial, com uso "sempre apropriada e cuidadosamente localizado" (2008, p. 16, tradução nossa) $)^{239}$. Em todos os casos, os textos das árias, sejam eles sobre desejo, ânsia ou lamento, são somados a uma música de afeto intimista, muito representativa do caráter musical ao qual o chalumeau normalmente se prestava.

Fora do território austríaco, outros compositores importantes também legaram páginas relevantes para o chalumeau. A figura de Vivaldi se destaca pelo uso do instrumento em algumas obras puramente instrumentais, nas quais utiliza o chalumeau (designado 'salmoè') em diferentes funções (inclusive como dobra da linha

\footnotetext{
238 "The concert-going public was evidently captivated by this new sound and the skill with which these composers wrote for it. The subject of the arias invariably concerns the vicissitudes of love, and the settings are often pastoral - scenarios that exploit the subtle and seductive colour of the instrument as well as its dynamic range and flexibility. The music frequently includes the indication affetuoso or cantabile, and the instrument is paired with other soft and sweet instruments such as the flute, recorder, viola d'amour and viola da gamba."

239 "always carefully and appropriately placed."
} 
do baixo contínuo) e também em música vocal. No Nisi Dominus, RV 803, um chalumeau tenor tem uma proeminente linha obbligato na ária de alto Cum dederit. A atmosfera da peça é delicada, o instrumento dialoga com a voz, ambos acompanhados por violinos e órgão tasto solo. A tessitura de todos os envolvidos é predominantemente grave, mas a música é de extrema leveza, fazendo jus à sonoridade aveludada do chalumeau.

No oratório Juditha Triumphans, Vivaldi utiliza-se do chalumeau apenas em uma ária, Veni, veni, me seguire fida, também de alto, buscando um momento de "efeito especial" trazido pelo instrumento. Normalmente optando pelo chalumeau tenor, Vivaldi aqui escreve para o soprano. A escolha do instrumento mais agudo é explicada pelo papel que desempenha na música, na qual sua linha é pensada em imitação do melancólico arrulhar de uma pomba. Por quase todo o movimento, Vivaldi prepara uma ambientação de sonoridade única, com o chalumeau e a voz acompanhados, sem o baixo, por violinos e violas em semicolcheias. De fato, essa sonoridade é aqui também muito especial, não sendo ouvida em nenhum outro momento do oratório. 


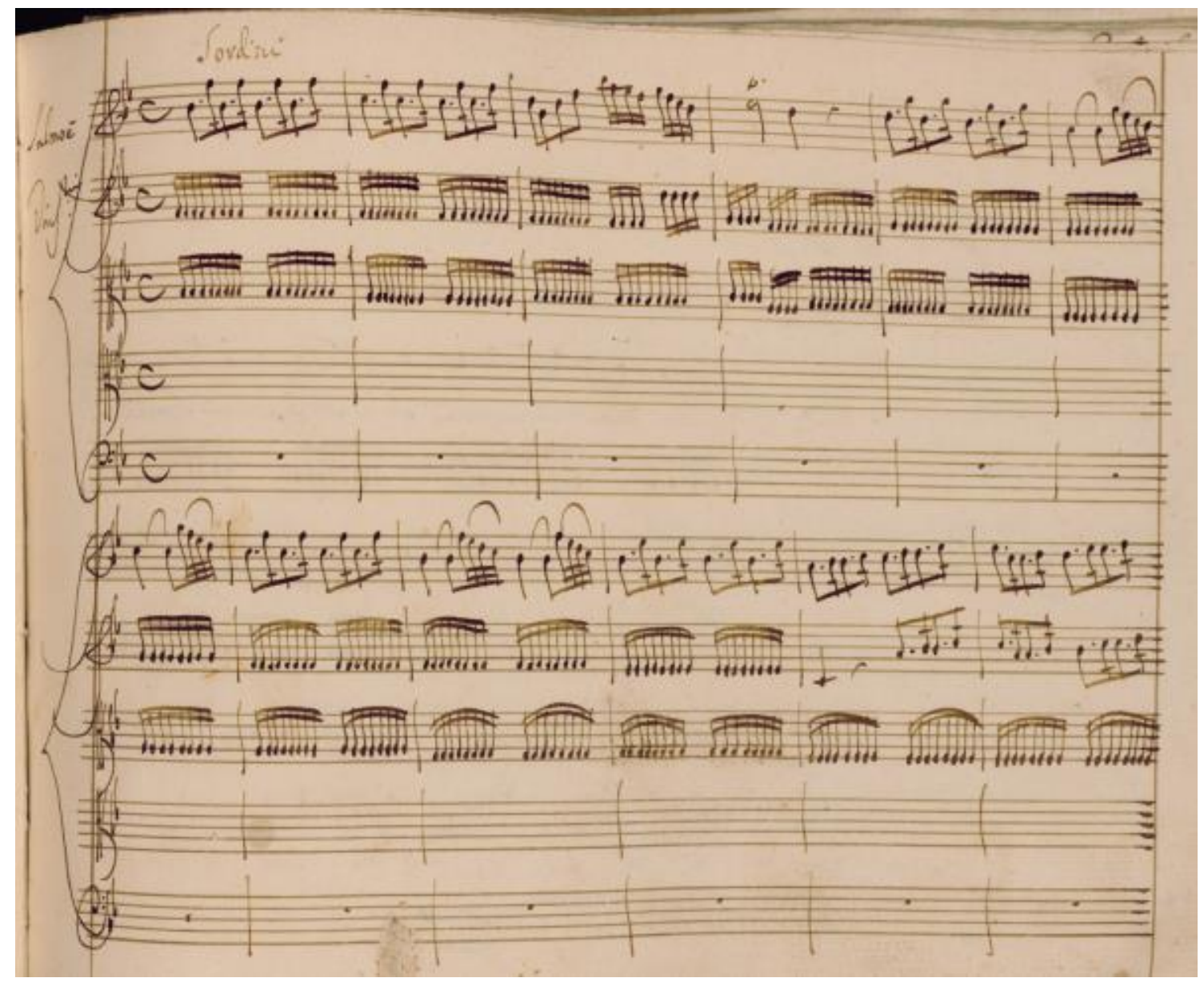

Fig. 48 - Início da ária Veni, veni, me seguire fida, de Juditha Triumphans, de Vivaldi (1716). Vêse a delicada linha de chalumeau soprano (escrita em imitação do canto de uma pomba) acompanhada por violinos em semicolcheias

Telemann, tão prolífico na escrita para praticamente todos os instrumentos de sopro disponíveis em sua época, não deixou de escrever para o chalumeau em quatro cantatas, além de empregá-lo em uma série de peças instrumentais, nas quais utiliza frequentemente os instrumentos alto e tenor, como um par. Graupner é o compositor que mais compôs para o chalumeau em obras vocais e instrumentais, sendo que "em meio à composição de tantas cantatas, teve a o oportunidade de usar chalumeaux em todas as formas possíveis, e incluir todos os quatro tamanhos do instrumento na extensão convencional de uma oitava mais três notas" (Hoeprich, 2008, p. 58, 
tradução nossa) $)^{240}$. Hoeprich cita ainda outros nomes que escreveram para o chalumeau, entre os quais Heinichen, Hasse, Zelenka e Gluck.

A análise e conhecimento do repertório do chalumeau torna curiosas as já vistas opiniões de Mattheson a respeito do instrumento, nas quais é caracterizado como "gritante" ou "barulhento". Não menos controversas são as opiniões de Buonanni, em seu Gabinetto Armonico (1722), a respeito do calandrone, cuja descrição física leva a crer que se tratasse do chalumeau de duas chaves, e sobre o qual o autor escreve como tendo uma sonoridade desagradável. Essas descrições do chalumeau são, como observa Hoeprich, muito estranhas "para um instrumento associado a um tocar cantabile e expressivo." (2008, p. 45, tradução nossa) $)^{241}$

Apesar de fadado ao desuso, o chalumeau foi utilizado até a segunda metade do século XVIII, quando compositores mais tardios como Hoffmeister e Dittersdorf dedicaram obras a ele. Não seria errôneo imaginar que o chalumeau, mesmo com suas limitações, foi muito benquisto durante boa parte do século XVIII. As palavras de Schubart, no seu já visto Ideen, ilustram esta questão, dizendo ainda em 1785 que "toda a gama musical sustentaria uma perda considerável se o instrumento [o chalumeau] se tornasse obsoleto." (DUBOIS, 1983, p.381, tradução nossa) 242

O primeiro registro documental referindo-se à clarineta data do início do século XVIII, como explica Hoeprich:

\begin{abstract}
A primeira aparição na Alemanha (como 'Clarinette') data de um documento de 1710, quando o Duque de Gronsfeld encomendou vinte e nove instrumentos musicais do ateliê de Denner. A conta discriminada lista duas clarinetas, a sete florins e meio cada - um pouco mais caras que os oboés, a cinco florins cada. (2008, p.21, tradução nossa) $)^{243}$
\end{abstract}

O início da história do instrumento se confunde de forma significativa com a do chalumeau. Rice afirma que

\footnotetext{
240 "In the course of composing so many cantatas, Graupner had the opportunity to use chalumeaux in every possible way, and to include all four sizes with the conventional range of an octave plus three notes."

241 "for an instrument associated with cantabile and expressivo playing."

242 "the whole scale of music would have a noticeable gap if this instrument were lost."

243 "The first appearance in Germany (as 'Clarinette'), dates to a document from 1710, when the Duke of Gronsfeld ordered twenty-nine musical instruments from the Denner workshop. The itemized bill, lists two clarinets, at $71 / 2$ florins each - slightly more expensive than the oboes, at 5 florins each."
} 
a pesquisa sobre o chalumeau é essencial para a discussão das origens da clarineta, uma vez que muitos chalumeaux de duas chaves sobreviventes do século XVIII são muito similares em aparência a clarinetas de duas chaves contemporâneas. De fato, por causa dessas similaridades, pode-se presumir que a clarineta de duas chaves desenvolveu-se a partir do chalumeau de duas chaves. Apesar disso, a evidência para essa suposição é inconclusiva. $(1992, \text { p. 38, tradução nossa) })^{244}$

Como menciona o autor, existe a ideia de que a clarineta teria sido criada a partir do chalumeau e muitas vezes esse último é tido como o seu "antecessor" ou "antepassado". Entretanto, isto se mostra totalmente errôneo, já que ambos os instrumentos conviveram por muito tempo e o chalumeau definitivamente não saiu de cena quando a clarineta surgiu.

Rice explica também as características essenciais da clarineta barroca, que a distinguem do chalumeau:

\begin{abstract}
A clarineta difere do chalumeau por ter sua chave dorsal posicionada mais acima, que encobre um furo menor, com um tubo que ajuda a produzir o registro de harmônicos superiores. Além disso, a construção do bocal da clarineta o torna mais efetivo na produção do registro de harmônicos, e a campana é maior e mais larga que o tubo, diferentemente dos pés parecidos com os de flauta doce apresentados por muitos chalumeaux. (1992, p. 38, tradução nossa) ${ }^{245}$
\end{abstract}

Em resumo, as partes mais originais da clarineta eram sua chave traseira, visivelmente mais alta do que a frontal (enquanto as dos chalumeau eram colocadas na mesma altura) que possibilitavam não só a produção de poucas notas que aumentavam sua tessitura fundamental mas, principalmente, permitiam a obtenção dos harmônicos com muito mais facilidade, e a presença da campana, que possibilitava uma projeção sonora mais efetiva.

\footnotetext{
244 "Our foregoing survey of the chalumeau is essential to a discussion of the origins of the clarinet, since several extant two-key chalumeaux of the eighteenth century are quite similar in appearance to contemporary two-key clarinets. Indeed, because of these similarities one might assume that the twokey clarinet was developed from the two-key chalumeau. However, the evidence for this assumption is inconclusive."

245 "The clarinet differs from the chalumeau in that the key on the clarinet's dorsal side is positioned higher and is given a smaller tone-hole, with a register tube to assist in producing the overblown register. In addition, the construction of the clarinet mouthpiece makes it more effective in producing the overblown register, and the bell is larger and has a definite flare to its bore, unlike the recorder-like foot of many chalumeau instruments."
} 
Evidentemente, o grande trunfo da clarineta era sua possibilidade de tocar notas mais agudas que o chalumeau (o instrumento tinha uma extensão maior). Os sons agudos de um instrumento de palheta-simples produziam no início do século XVIII uma sonoridade também bastante nova, e essa novidade despertou o interesse dos compositores da época. De fato, a maior parte da música escrita para a clarineta barroca na primeira metade do século pede por seu registro agudo em grande parte do tempo. Seu registro grave era tocável mas, no entanto, apresentava fraqueza e falta de foco sonoro, em contraste com o chalumeau, cujos sons fundamentais mostravam maior beleza e melhor projeção do som. Assim, os dois instrumentos produziam uma espécie de antagonismo sonoro: o chalumeau com seus graves aveludados e a clarineta com seus agudos brilhantes.

A maioria das clarinetas da primeira metade do século XVIII eram construídas em dó ou ré (o que explica o fato de grande parte de seu repertório dessa época ser composto nessas tonalidades), possuíam duas ou três chaves e podiam apresentar sonoridade pungente e até mesmo estridente.

Desde muito cedo parece ter havido a associação da sonoridade aguda da clarineta àquela de outro instrumento. Essa associação teve tal grau de importância na história da clarineta que além de regrar seu primeiro uso musical e escrita idiomática foi também, muito provavelmente, a grande responsável por sua nomenclatura.

Em 1732, o Musikalisches Lexicon de Walther dava a seguinte descrição para o verbete Clarinetto:

um instrumento de sopro de madeira inventado no início deste século por um Nuremberguense, parecido com um longo oboé, exceto por seu bocal mais largo; à distância ele soa um pouco como um trompete e tem uma extensão de fá a ré. (HOEPRICH, 2008, p. 22, tradução nossa) ${ }^{246}$

A associação do som da clarineta ao do trompete ocorrerá também em outros documentos, como no já mostrado Theatrum de Weigel, por exemplo. Ainda em 1750, um mezzotint de Ridinger ilustrando um clarinetista tocando seu instrumento ao ar livre, apresenta o seguinte texto:

246 "a woodwind instrument invented at the beggining of this century by a Nürnberger, not unlike a long oboe, except for its wide mouthpiece; from far away [it] sounds a bit like a trumpet and has a range from $f$ to d." 
Como o nome que carrega, seu som é claro e puro

Muito à maneira de um trompete; ainda que todo doce

Ah, se ao menos alguém tivesse um virtuoso

que, em uma noite quieta, pudesse para ele tocar gentilmente até que adormecesse.

Nenhum outro tipo de palheta fura o ar mais claramente,

apropriadamente imitando com seu som a canção do doce trompete.

Ouvir seu cantar através da amigável quietude da noite,

Pode acalmar os membros do corpo, e a mente. (HOEPRICH, p. 27, 28, tradução nossa) $)^{247}$

No início do século XVIII era comum que os alemães chamassem o registro agudo dos trompetes de clarino. Como os sons brilhantes da clarineta lembravam esse registro, ela foi nomeada como um "pequeno clarino", termo que em italiano era transposto para clarinetto, (e modificado para o Klarinette alemão e o clarinette francês).

Como os sons da clarineta eram, apesar de bastante brilhantes, considerados mais doces que os do trompete, eram comparados aos desse último, mas "à distância". Em suma, o instrumento soaria como um trompete ouvido ao longe. Não é de surpreender, portanto, que o primeiro repertório da clarineta fosse escrito quase que "em imitação do trompete", sendo que, á época, era considerada idiomática para o instrumento uma escrita que privilegiasse essa imitação. Rice define com detalhes a questão:

Música com partes pensadas especificamente para a clarineta barroca começou a aparecer durante a segunda década do século XVIII. A maioria dessas partes exibe um estilo de escrita caracterizado por notas repetidas, arpejos incompletos, motivos de fanfarra, extensão limitada e uso restrito do registro grave. (1992, p. 79, tradução nossa) ${ }^{248}$

\footnotetext{
247 "Like the name it bears, its sound is clear and purê, much in the manner of a trumpet; yet all douce and sweet Ah, i fone only had a Virtuoso who, on a quiet night, might blow him gently to sleep! No other kind of reed breaks the air more clearly, fittingly imitating with its tone the song of the sweet trumpet. To hear its singing through the friendly stillness of the night can becalm the body's members, and the mind."

248 "Music with parts intended specifically for the baroque clarinet began to appear during the second decade of the eighteenth century. The majority of these parts exhibit a style of writing characterized by repeated notes, incomplete arpeggios, fanfare motifs, a limited range, and restricted use of the low register."
} 
Mesmo dentro desse contexto de imitação, a clarineta apresentava a vantagem de poder tocar notas que eram impossíveis no trompete da época, cujos sons executáveis estavam restritos às notas da série harmônica.

Com o passar do tempo, outros atributos da clarineta começaram a ser utilizados e, ainda que as qualidades anteriores de sua música se mantivessem, outro tipo de "idioma" surge:

Em obras compostas depois de 1730 , outras características que tomam grande importância são um estilo lírico de escrita melódica, passagens com escalas, saltos de uma oitava ou mais, e um mais frequente uso do registro grave. (RICE, 1992, p. 79, tradução nossa) ${ }^{249}$

Durante a primeira metade do século XVIII, a clarineta, por ser um instrumento novo, não ganhará um repertório vasto como as outras madeiras. No entanto, grandes compositores da época escreveram para ela, como Telemann, Vivaldi, Handel e Rameau.

Telemann usou a clarineta em algumas cantatas e sua Serenata, zum Convivio der HH Burgercapitains é icônica pela forma como utiliza e combina o instrumento:

Aqui, Telemann pareia uma clarineta em ré com um trompete em ré, praticamente não fazendo distinções entre os dois nas partes escritas - de fato, eles dividem o mesmo pentagrama em muitos trechos da partitura, e a música nessas partes transpostas é perfeitamente idiomática. A associação de trompete e clarineta sugere que na ocasião o clarinetista poderia ter substituído um trompetista não disponível. (HOEPRICH, 2008, p. 33, tradução nossa) $)^{250}$

Essa obra de 1728 é um dos exemplos da escrita idiomática muito similar entre os dois instrumentos.

\footnotetext{
249 "In works composed after about 1730, other characteristics which take on a greater importance are a lyrical style of melodic writing, scale passages, leaps of an octave or more, and a more frequent use of the low register."

250 "Here, Telemann pairs a clarinet in D with a trumpet in D, hardly distinguishing between the two in the part writing - in fact, they share the same staff in several places in the score, and the music in these transposed parts is perfectly idiomatic. The association of trumpet and clarinet suggests that on this occasion the clarinettist substituted for an unavailable trumpet player."
} 
Vivaldi destaca-se entre os compositores barrocos que escreveram para a clarineta principalmente pela maneira como utiliza seu registro grave e os contrastes com as outras regiões do instrumento. Em seus concertos nos quais figuram a clarineta (sempre em par) - RV 556, RV 559 e RV 560 - suas notas graves são exploradas de forma nova. Braun afirma que, principalmente nos dois últimos, "Vivaldi foi proficiente escrevendo idiomaticamente para a clarineta de um modo ao qual seus contemporâneos nunca se igualaram" (2016, p. 37) e dá mais detalhes sobre isso:

É nesses dois concertos [RV 559 e 560] que Vivaldi prova seu conhecimento desse novo instrumento inventado: ele explora o conhecido contraste nos timbres produzidos em cada registro. A porção grave da primeira clarineta era famosa por seu som escuro, dedilhados difíceis, alturas obscuras ou inacessíveis em muitas notas e uma inabilidade de projeção de som. Em contraste absoluto, o registro agudo (...) projetava fortemente com uma cor brilhante e soava como um cruzamento entre um sopro de madeira e um trompete. Vivaldi usou esse conhecimento para compor de forma eficaz e idiomática para o instrumento. Sua exploração das capacidades técnicas da clarineta bem como de suas cores tonais contrastantes foi única em composições para o instrumento no início do século XVIII.

(...) O primeiro concerto que Vivaldi escreveu para clarinetas é o densamente orquestrado RV 556 (c.1718). A clarineta barroca parece ser retratada em seu papel arquetípico: imitando o trompete em seu registro agudo. Inesperadamente, Vivaldi expõe o não-refinado registro chalumeau da clarineta e seu timbre notoriamente sem foco. Lawson explica a irregularidade e engenhosidade da exploração de Vivaldi do registro chalumeau com a seguinte informação, "Vivaldi foi o primeiro compositor a usar o registro grave da clarineta de duas chaves, e isso é um desafio."

(...) esta falha infame da clarineta não dissuadiu Vivaldi de explorar o registro grave do novo instrumento em seu RV 559. Vivaldi capitalizou-se na cor obtida pelo registro grave notoriamente fraco e acentuou a sonoridade com um volume mais suave no continuo e frequentemente com uma mudança dramatizada para uma tonalidade menor. $O$ brilhante registro de clarino parecido com o trompete produzia uma ressonância contrastante com a do registro chalumeau e foi igualmente explorado por Vivaldi em passagens rápidas e arpejadas que lembram os toques de trompete.

(...) Este concerto [RV 560] novamente ilustra o conhecimento e compreensão de Vivaldi das habilidades e timbres dos diferentes registros da clarineta. Vivaldi usa o súbito e desfocado timbre do registro chalumeau para adicionar um inigualável ambiente de desilusão para seções sombrias normalmente em tonalidade menor. $O$ registro agudo é tratado de forma muito diferentes com as duas clarinetas em terças frequentemente imitando toques de trompete. (BRAUN, 2016, p. 18, 35, 37 e 27, tradução nossa) $)^{251}$

251 "It is in these two concerti that Vivaldi proves his knowledge of the newly invented instrument: he exploits the well-known contrast in the timbres produced in each register. The lower range of the early clarinet was renowned for its murky tone, difficult fingerings, obscure or inaccessible pitches on several notes and an inability to project loudly. In stark contrast, the clarino (upper) register (...) projected loudly with a bright color and sounded like a cross between a woodwind and a trumpet. Vivaldi used this 
40

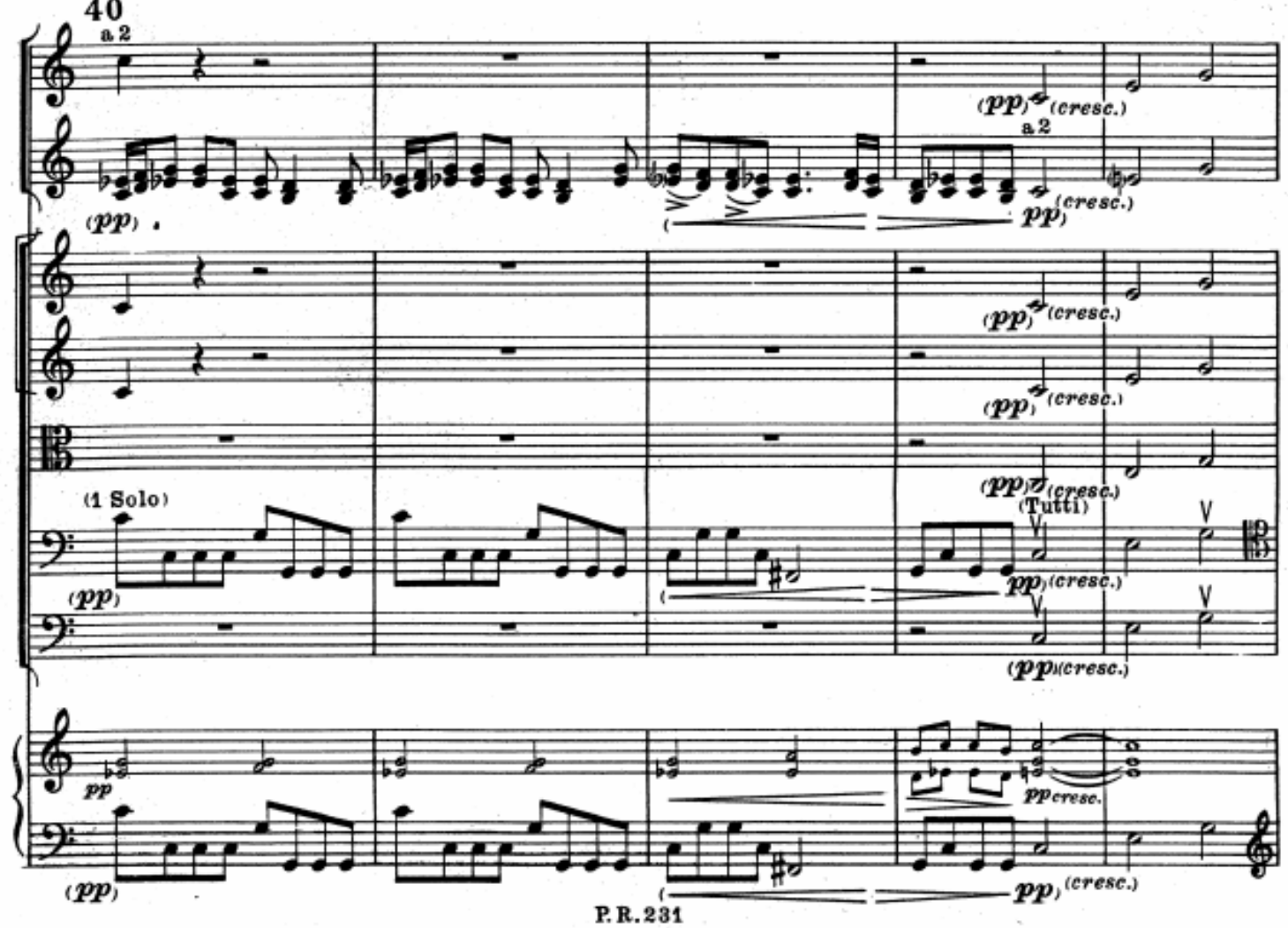

Fig. 49 - Excerto do primeiro movimento do Concerto para dois oboés e duas clarinetas, RV 560, de Vivaldi. No segundo pentagrama, nota-se a escrita na região grave das clarinetas, em um momento contrastante em modo menor

knowledge to compose effectively and idiomatically for the instrument. His exploitation of the clarinet's technical capacity and contrasting tonal colors was unique in clarinet compositions in the early $1700 \mathrm{~s}$.

(...) The first concerto that Vivaldi wrote for clarinets is the thickly scored RV 556 (c. 1718). The baroque clarinet appears to be portrayed in its archetypal role: mimicking the trumpet with its upper register. Unexpectedly, Vivaldi exposes the unrefined chalumeau register of the clarinet and its notoriously unfocused timbre. Lawson explains the irregularity and ingenuity of Vivaldi's exploration of the chalumeau register with the following information, 'Vivaldi was the first composer to use the low register of the 2-key clarinet, and that's a challenge'.

(...) this infamous flaw of the clarinet did not dissuade Vivaldi from exploring the lower register of the new instrument in his RV 559. Vivaldi capitalized on the color achieved from the notoriously weak low register and accentuated the sonority with a softer volume in the continuo and often a dramatized shift to a minor key. The bright trumpet-like clarino register produced a contrasting resonance than the chalumeau register and was equally exploited by Vivaldi in arpeggiated, fast passages that resemble trumpet calls.

(...) This concerto again showcases Vivaldi's knowledge and understanding of the abilities and timbres of the different registers of the clarinet. Vivaldi uses the subtle and unfocused timbre of the chalumeau register to add an unmatched despondent tone to somber sections often in a minor key. The upper register is treated very differently as the two clarinets in thirds frequently mimic trumpet calls." 
Os textos de Braun, além de exaltarem a importância de Vivaldi em meio ao repertório da clarineta, elucidam também a relevante questão envolvendo a notável diferença entre os registros do instrumento. De fato, essa diferença parece ter sido vista como um tipo de "defeito" presente na clarineta e a resolução desse problema, que se daria mais tarde, seria muito marcante na história do instrumento, como comentar-se-á adiante.

Rameau utilizou clarinetas em três de suas óperas, sendo que tanto em Zoroastre (1749) como em Les Boréades (1764) os instrumentos foram usados na orquestra. Porém, não há partes específicas para eles (provavelmente tocavam dobras ou ainda substituíam outras madeiras). Já em Acante et Céphise (1751), o compositor usou um par de clarinetas de forma prolífica:

\begin{abstract}
Ambos os instrumentos em dó e ré são pedidos, e Rameau os utilizou com confiança de forma nova e imaginativa. Fanfarras com toques de trompete e escalas são inclusas, mas muito das partes pedem por toque expressivo e melódico, ocasionalmente junto aos violinos. Em diversos pontos as clarinetas também tocam junto com as trompas. (HOEPRICH, 2008, p. 38, tradução nossa) $)^{252}$
\end{abstract}

O uso de clarinetas por Rameau é pioneiro, uma vez que esses instrumentos chegaram tardiamente em território francês (La Borde, em seu Essai sur la musique, afirma em 1780 que a França conhecia a clarineta havia trinta anos e Ancelet, no já visto Observations sur la musique de 1757, lamenta o fato do instrumento ser, até então, ignorado pelos franceses).

Como mencionado, a música de Acante et Céphise é muito interessante por utilizar diferentes facetas da clarineta, mostrando um pouco de sua versatilidade.

Mesmo sendo mais nova que as outras madeiras presentes no século XVIII, a clarineta seria inserida na música extremamente retórica da época e, portanto, também passaria, naturalmente, a exercer um papel alegórico quando usada nas composições. Também diferentemente das outras madeiras, a clarineta não tinha

\footnotetext{
252 "Both clarinets in C and D are required, and Rameau used the instruments with confidence in a novel and imaginative way. Trumpet-like fanfares and scales are included, but much of the passage work also requires expressive, melodic playing, occasionally together with the violins. In several spots the clarinets also play together with the horns."
} 
antecedentes muito diretos de uso alegórico na música, uma vez que os instrumentos que podem ser considerados seus antepassados (aqueles de palheta-simples) passam a ser mencionados apenas em descrições dos séculos XVII e XVIII (ao contrário das flautas, do oboé e do fagote, que têm antecessores muito conhecidos já utilizados na música 'séria' desde o Renascimento), e que, por sua vez, eram instrumentos folclóricos muito simples, não servindo para a música de maior complexidade. Sendo assim, pode-se supor que juntamente com a invenção da clarineta (e também do chalumeau) foi necessária a criação de um repertório simbólico e alegórico para o instrumento, levando em consideração sua sonoridade, suas possibilidades expressivas e seu parentesco com outros instrumentos, entre outras questões.

As claras associações com o trompete poderiam dar indicações do uso alegórico da clarineta na primeira metade do século XVIII, já que ela normalmente servia para mimetizar o primeiro. No entanto, não é possível afirmar que ela tenha tomado para si também os significados alegóricos do instrumento de metal. Desde centenas de anos antes, o trompete trazia consigo associações diretas com o divino e a nobreza, com o poder, a exuberância e o esplendor de Deus ou dos monarcas com seus exércitos. No século XVIII, essa associação ainda era fortemente vivenciada. A clarineta, com seu som mais adocicado de "um trompete ao longe" poderia trazer a lembrança do instrumento, mas dificilmente poderia tomar para si toda a pompa alegórica do trompete. Ainda que na citada obra de Telemann a clarineta possa ter sido pensada como possível substituta para o instrumento, essa não parece ter sido uma prática extremamente recorrente na música da época. Grosso modo, a clarineta não poderia tomar com força o lugar do trompete, musical ou alegoricamente. O repertório conhecido não demonstra claramente que a clarineta e o trompete foram considerados como instrumentos irmãos e que tenham sido abundantemente usados juntos, de forma complementar, ou ainda em verdadeira substituição um do outro. Pelo contrário, a clarineta setecentista criou ligações mais fortes e recorrentes com outro instrumento de metal, a trompa, e essa associação dá pistas sobre alguns de seus significados alegóricos mais prováveis.

Garsault, em seu volume enciclopédico Notionaire, publicado em 1761, dedica uma seção do documento aos instrumentos musicais, que aparecem divididos em grupos definidos por sua função. Curiosamente, a clarineta, que o autor também 
chama de "oboé campestre", figura entre os ditos "instrumentos de guerra e de caça", e a ordem através da qual Garsault os apresenta deixa subentendida a separação do trompete, dos tímpanos, do pífaro (fifre) e da caixa como os instrumentos de guerra e da trompa e clarineta como os de caça (aliás, ambas aparecem juntas em uma mesma ilustração).

Esse lugar da clarineta clarifica o instrumento como sendo propício a paisagens pastorais, cenas ao ar-livre, atribuindo a ele um certo grau de rusticidade, comum também às trompas. Garsault explica que a clarineta possui a vantagem de ser

alegre e sonora, e de servir muito bem aos Concertos juntamente com as trompas-de-caça. É raro que obtenha êxito sozinha, devido à dureza de seu som que é difícil de se aveludar. (1761, p. 647, tradução nossa) ${ }^{253}$

O autor parece ignorar o aspecto mais doce do instrumento, já conhecido e utilizado anteriormente. De qualquer modo, sua opinião sobre a clarineta demonstra uma visão que a aproxima alegoricamente das outras madeiras, às quais o aspecto pastoral está frequentemente ligado.

Clarinetas e trompas formavam uma combinação que parecia muito bem-quista já nos arredores de 1750. Hoeprich afirma que "Parear clarinetas com trompas tornouse comum nesse período, criando uma tendência seguida por muitos compositores mais tarde no século XVIII." (2008, p. 38, tradução nossa) $)^{254}$. Rice $(1992$, p. 154) fala sobre a grande popularização de seu uso na Paris da década de 1750 e Baines (1967, p.298, tradução nossa) explica que "a clarineta de duas chaves foi introduzida na França e na Inglaterra pelos alemães que a tocavam em conjunto com a trompa, aparentemente em um vigoroso estilo ao ar-livre." 255 Ancelet explicita seu gosto pela combinação em sua publicação de 1757. Rameau utilizou-a de forma eficaz em cenas pastorais e de caçada na já mencionada Acante et Céphise. Por volta de 1740, Handel privilegiou essa combinação em sua Overture, H 424, para duas clarinetas e trompa. De

\footnotetext{
253 "gai \& sonore, \& de faire três-bien dans le Concerts mêlé avec les Cors-de Chasse. II est rare qu'il réussisse seul à cause de la dureté du son qu'il est difficile d'adoucir."

254 "Pairing clarinets with horns became common in this period, setting a trend followed by many composers later in the eighteenth century."

255 "This two-keyed clarinet was introduced to France and England by Germans who played it in partnership with the horn, apparently in vigorous open-air fashion."
} 
fato, existem muitas fontes de época confirmando essa associação como bemsucedida e frequente.
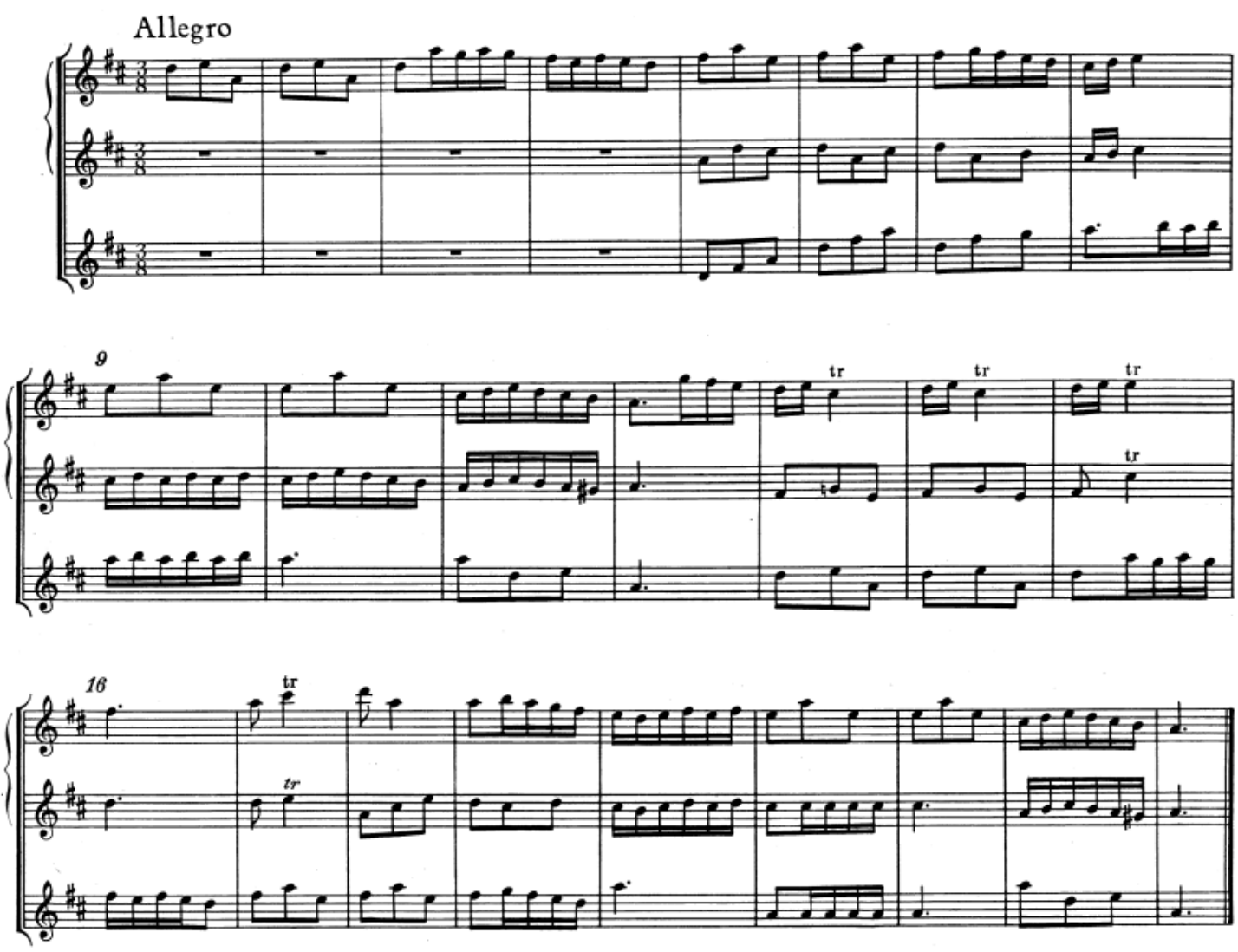

Fig. 50 - Início do quinto movimento da Overture HWV 424, de Handel, para duas clarinetas e trompa

Essas informações, além do repertório em si, podem levar à compreensão da clarineta, ao menos até meados do século XVIII, como um instrumento alegoricamente voltado a "fanfarras pastorais", se o termo puder ser assim considerado. Mesmo apresentando possibilidades de lirismo, a clarineta parece ter cumprido mais frequentemente seu papel de instrumento voltado à sonoridade brilhante de seu peculiar registro agudo, aplicado a paisagens marciais ou campestres.

Assim, pode-se imaginar a clarineta e o chalumeau ocupando lugares alegoricamente diferentes durante o século XVIII. Como colocado por Rice, "uma comparação da música para chalumeau e para clarineta mostra inequivocamente que os papeis musicais desses instrumentos eram distintamente separados." (1986, p. 553, 
tradução nossa) $)^{256}$. Isso fica claríssimo a partir da análise do trabalho de um mesmo compositor escrevendo para os dois instrumentos. Obras de Vivaldi, Handel, Telemann, Graupner e de tantos outros que assim o fizeram explicitam que chalumeau e clarineta eram vistos como veículos diferentes que deveriam ser usados de forma distinta. Obviamente, ambos os instrumentos foram utilizados de modo a privilegiar seus melhores atributos e esse fato criava uma dicotomia entre os dois, concernente a seus registros e qualidades sonoras mais aplicadas às composições e também a seu uso alegórico: o chalumeau era utilizado por suas notas fundamentais, surpreendentemente graves e delicadas, em música que mesclava paisagens pastorais a afetos de caráter intimista e muito sentimentais. A clarineta era musicalmente mais valorizada em seus pungentes agudos e aplicada em música de caráter também pastoral (porém, mais rústico) e vivo. Lawson resume de forma interessante a aplicação musical de ambos os instrumentos, a partir da associação deles a outros: "O trabalho de compositores conhecedores de ambos os instrumentos ilustram bem a relação do chalumeau com a flauta doce e da clarineta com o trompete." (1979, p.351, tradução nossa) ${ }^{257}$

No entanto, apesar dessas distinções, o fato de serem instrumentos irmãos mantinha entre eles alguma semelhança. Em 1738, Eisel escreve em seu Musikus Autodidaktus:

Qual clave é usada para a clarineta? A usual e própria notação para esse instrumento é geralmente a clave de sol e ela é então usada como um trompete, mas algumas vezes as claves de soprano e de alto são usadas, quando a clarineta é tratada com um chalumeau. (LAWSON, 1986, p. 554, tradução nossa) ${ }^{258}$

Além de elucidar a diferenciação de papéis dos instrumentos, Eisel também sugere que o registro grave da clarineta era associado ao chalumeau. De fato, essa associação deu nome à região grave do instrumento, assim chamada até a atualidade.

\footnotetext{
256 "A comparison of the music for the chalumeau and clarinet shows unequivocally that the musical roles of these instruments were distinctly separate."

257 "The works of composers acquainted with both instruments well illustrate the relationship of the chalumeau to the recorder, and of the clarinet to the trumpet."

258 "'What clef is used for the clarinet? The usual and proper notation for this instrument is generally the treble clef and it is then used like a trumpet, but sometimes soprano and alto clefs are used, when the clarinet is treated like a chalumeau."
} 
Como visto, o chalumeau foi utilizado por pelo menos três quartos do século $\mathrm{XVIII}$, durante os quais as características únicas de sua sonoridade mantiveram-no no cenário musical, apesar de suas limitações em relação às outras madeiras. Porém, ele cairá em desuso, e esse fato pode ser relacionado ao desenvolvimento da clarineta a partir da segunda metade do referido período. Hoeprich (2008, p. 63, tradução nossa) afirma que "é difícil dizer exatamente como e quando as clarinetas de duas e três chaves em ré e dó metamorfosearam-se no conjunto clássico de clarinetas de cinco chaves em dó, si bemol e lá"259, mas, de qualquer modo, as mudanças pelas quais o instrumento passou foram transformadoras e levaram-no a novas significações musicais.

Sobre o uso concomitante da clarineta e do chalumeau, Lawson afirma:

O fato de que a identidade separada dos dois instrumentos foi mantida até o último quarto do século é pouco surpreendente quando se considera os problemas ainda encontrados pelos construtores de clarinetas em harmonizar (igualar) seus registros fundamental e de harmônicos. (1979, p. 351 , tradução nossa) $)^{260}$

Unificar a clarineta com seus conhecidos registros de caracteres muito discrepantes parece ter sido uma das principais preocupações dos luthiers. Assim, a partir da segunda metade do século XVIII, o efeito dessa preocupação começa a ser visto nos novos instrumentos, que aos poucos vão mostrando sonoridade mais "igualada" ao longo de toda sua extensão. Logicamente, os três registros da clarineta (grave, médio e agudo) ainda mantêm suas peculiaridades, mas podem ser utilizados em maior pé de igualdade. De modo geral, a clarineta, mesmo com seus sons agudos ainda penetrantes, torna-se aos poucos um instrumento mais doce e sutil, e serão essas suas características as mais apreciadas durante o Classicismo.

Com um registro grave que agora permitia maior projeção e afinação, ao mesmo tempo que mantinham seus sons delicados e aveludados, as novas clarinetas

\footnotetext{
259 "it is difficult to say exactly how and when two- or three-key clarinets in D and C metamorphosed into the Classical set of five-key clarinets in C, B flat and A."

260 "That the separate identity of the two instruments was retained until the last quarter of the century is scarcely surprising when one considers the problems still encountered by clarinet manufacturers in tuning fundamental and overblown registers together."
} 
foram aos poucos suplantando a necessidade do chalumeau, cujo papel poderiam exercer perfeitamente.

A visão da clarineta como um instrumento doce e amoroso é predominante na segunda metade do século XVIII. Durante esse período, seu uso em música vocal ou instrumental tende cada vez mais a mostrar esse aspecto. A rusticidade das antigas fanfarras escritas para o instrumento dá lugar a um lirismo refinado tocado por sons repletos de sutileza, exaltados por Vanderhagen em seu método para clarineta, de 1785: "A beleza da clarineta jaz em seu som doce; essa é sua essência, e mesmo um executante medíocre pode encantar o ouvinte com esse instrumento." (HOEPRICH, 2008, p.63, tradução nossa) $)^{261}$

A clarineta ganha maior repertório a partir de 1750 . Além de passar a ser mais utilizada em obras orquestrais e na ópera, seu papel de solista começa a ter maior visibilidade (nomes como Johann e Carl Stamitz, Pleyel, Hoffmeister, entre outros, escreverão concertos para o instrumento) e o gênero de música para sopros, a Harmoniemusick, dará também lugar de destaque a ela.

Mozart é um dos compositores mais importantes na história da clarineta. Sua amizade com o virtuoso Anton Stadler rendeu ao instrumento algumas das obras mais importante de seu repertório, como o Quinteto K.581 e o Concerto K.622 (ainda que tenham sido compostos muito provavelmente para um tipo especial de clarineta, conhecida como basset).

O uso que Mozart faz do instrumento em suas óperas é icônico em relação a seu emprego alegórico:

'Così fan tutte' fornece uma pista sobre o que Mozart sentia que poderia
expressar através da clarineta. Poucos anos antes, Daniel Schubart tinha
descrito a clarineta como 'o som de grande sentimento - o tom de um
coração apaixonado derretendo de amor'. Na ária 'Ė amore um ladroncello',
em que as clarinetas são proeminentes, o texto descreve como 'o amor
chega no coração de alguém', sugerindo que Mozart, assim como Schubart,
associava a clarineta com o amor. Mais tarde na ópera, quando Ferrando
finalmente declara seu amor a Fiordiligi, ele é respondido por uma clarineta
solitária. (O oboé, por outro lado, representa o marido traído; a trompa, o
adultério). Através da ópera e de outras obras, clarinetas podem ser ouvidas
sempre que o tema é o amor. No Figaro, a ária 'Voi che sapete' inicia com o

261 "The beauty of the clarinet lies in its sweet sound; this is its essence, and even a mediocre player can delight the listener with this instrument." 
tema tocado por um par de clarinetas." (HOEPRICH, 2008, p. 102, tradução nossa $)^{262}$

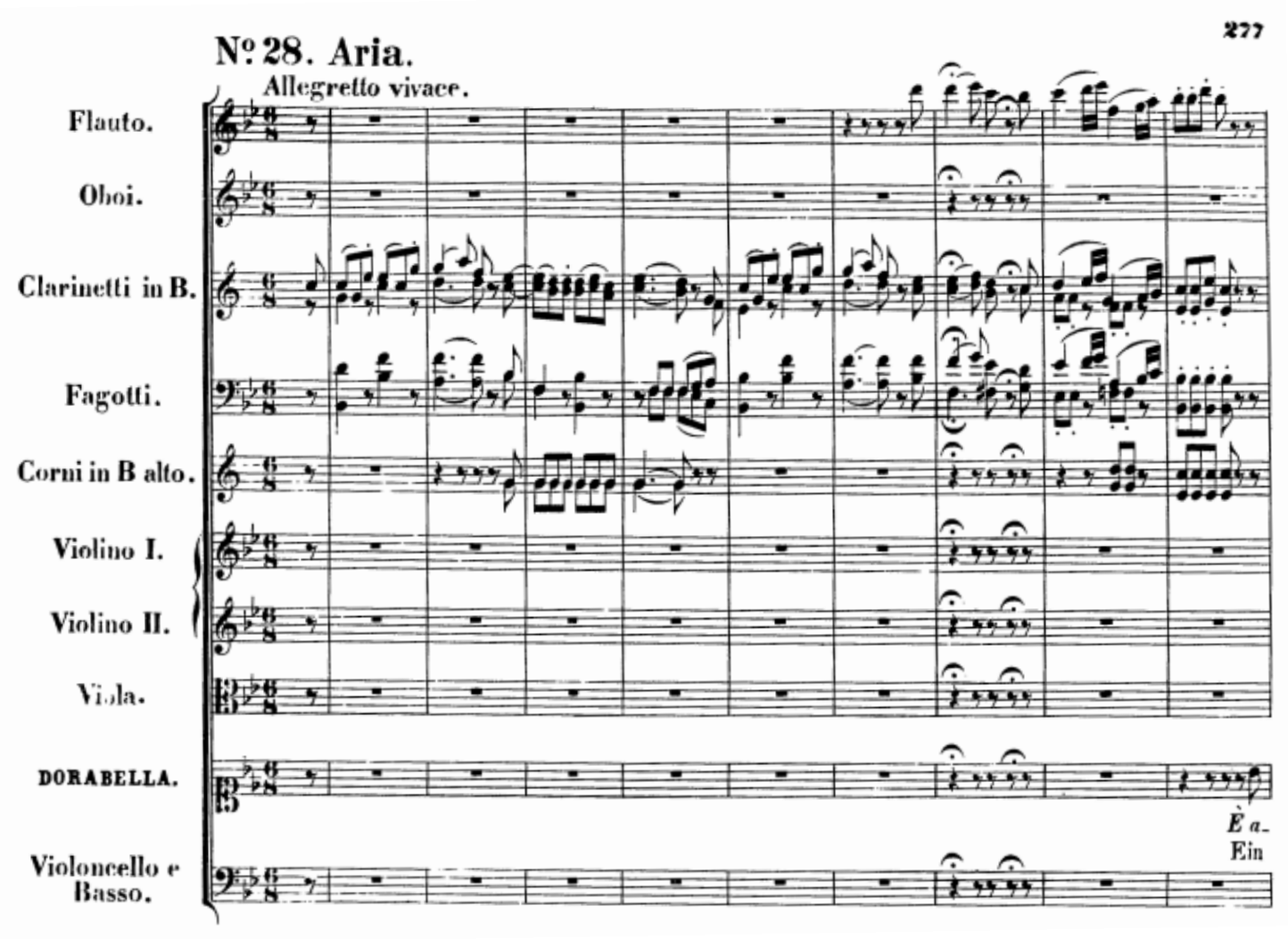

Fig. 51 - Início de È amore un ladroncello, do segundo ato de Così fan tutte K 588, de Mozart.

As clarinetas têm partes proeminentes, mostradas já no começo da ária

A partir de seu relevante repertório composto em fins do século XVIII, pode-se pensar que é durante o Classicismo que a clarineta passa ser equiparada às outras madeiras em níveis de importância e, mesmo que tardiamente, o instrumento terá seu lugar conquistado na orquestra clássica.

262 "Cosí fan tutte provides a clue to what Mozart felt he could express through the clarinet. A few years earlier, Daniel Schubart had described the clarinet as 'the sound of a great sentiment - the tone of a passionate heart melting with love'. In Dorabella's 'È amore um ladroncello', where the clarinets are prominent, the text describes how 'love settles in one's heart', suggesting that Mozart, just as Schubart, associated the clarinet with love. Later in the opera, when Ferrando finally declares his love for Fiordiligi, he is answered by a lone clarinet. (The oboe, on the other hand, represents the cuckold; the horn, adultery.) Throughout the opera and other works, clarinets can be heard whenever the subject is love. In Figaro, the aria 'Voi che sapete' opens with the theme played by a pair of clarinets." 


\subsection{0 fagote}

O primeiro uso do fagote em uma ópera deu-se na segunda metade do século XVII, de acordo com a afirmação de Langwill:

É com Cesti (1620-69) que encontramos o mais antigo uso operístico do fagote, viz. em II pomo d'oro (1667-8). Partituras desse período ocasionalmente incluem partes para instrumentos de sopro mas mais frequentemente apenas vagas indicações sugerem que outros além de instrumentos de corda são incluídos. Cesti, no entanto, por vezes especifica claramente os sopros, como nos dois ritornelli e no acompanhamento de um longo solo vocal, onde escreve para dois cornetos, três trombones e um fagote. Em outro momento ele emprega o mesmo grupo com adição de um regal para sugerir os terrores do Hades. $(1975, \text { p. } 75 \text {, tradução nossa) })^{263}$

Além de trazer informação sobre o uso dos instrumentos de sopro e de como eles eram especificados nas partituras da época, o trecho citado também aponta questões que podem ser envolvidas no uso alegórico do fagote.

É preciso dizer que em Cesti, assim como em outros compositores do período, o instrumento utilizado teria sido mais propriamente uma dulciana, ou seja, um antecessor do instrumento francês que tornar-se-ia o modelo principal do fagote barroco. De fato, as antigas dulcianas, oriundas do Renascimento, continuariam a ser utilizadas simultaneamente ao fagote barroco por parte do século XVIII, ainda que seu uso tenha sido gradualmente obscurecido pelo último, até que o instrumento renascentista caísse em desuso.

Do século XVI até o XVIII, diferentes termos são encontrados para designar tanto o novo fagote francês construído em 4 partes como seus antecessores de apenas uma peça: curtal, basson, fagote e dulciana (com diversas variações, de acordo com o local e a língua utilizada). De forma confusa, esses termos se misturam na designação tanto de instrumentos distintos como de um mesmo. De qualquer forma, ainda que

263 "It is with CESTI (1620-69) that we find the earliest operatic use of the bassoon, viz. in II pomo d'oro (1667-8). Scores of this period occasionally include parts for wind instruments but more often only vague indications suggest that other than stringed instruments are included. Cesti, however, sometimes clearly specifies the wind instruments, as in two ritornelli and in the accompaniment to one long vocal solo, he writes for two cornetti, three trombones and a bassoon. At another point he employs the same group with the addition of a regal to suggest the terrors of Hades." 
diferentes, esses instrumentos eram muito próximos e poderiam compartilhar algumas formas de utilização musical.

Desse modo, a afirmação de Langwill parece estender o uso alegórico da dulciana também para o fagote. É curioso que Cesti tenha pedido pelo instrumento em cenas infernais (uma no primeiro ato, na corte de Plutão e Proserpina, e outra no segundo, com Caronte sobre o rio Styx), uma vez que, como visto, as dulcianas, juntamente com outros instrumento de sopro de palheta, eram desde Renascença mais associadas a questões pastorais. O compositor junta a dulciana ao corneto e ao trombone, já em Monteverdi cotados como instrumentos para a representação do Hades. Essa ideia pode ter se dado pelo fato das dulcianas apresentarem sonoridade grave e encorpada, suscetível então à representação do submundo, por seu timbre anasalado que poderia combinar-se àquele do regal, também incorporado às cenas, ou ainda por ambos os motivos. De fato, essa não será a última vez que utilizar-se-á o instrumento alegoricamente através dessa associação.

Baines escreve sobre o instrumento francês e o termo a ele relacionado:

O termo basson já ocorre no começo do século XVII como um nome para o curtal. Mas Mersenne descreve como basson um tipo especial de curtal baixo com a campana alongada a fim de alcançar o Sib 0, provavelmente para se enquadrar à extensão dos cellos de Louis XIII, que eram afinados um tom abaixo do normal. Remodelado em quatro partes que se encaixavam, sem dúvida pelos membros do círculo dos Hotteterre, esse se tornou o verdadeiro fagote, que chegou na Londres de Purcell sob o nome de French basson. Ele é nomeado pela primeira vez numa partitura de Lully em 1674, mas pode muito bem ter sido utilizado dez ou mais anos antes. (1991, p. 286 , tradução nossa) $)^{264}$

De fato, Kopp explica que "o fagote barroco foi usado mais cedo e com maior frequência do que as partituras e partes sobreviventes mostram" (2012, p. 65, tradução nossa) ${ }^{265}$ citando Hutchings:

\footnotetext{
264 "The name basson already occurs at the beginning of the seventeenth century as a name for the curtal. But Mersenne describes as basson a special type of bass curtal with the bell lenghtened to reach $B^{\prime} b$, presumably in order to match the compass of Louis XIII's cellos, which were tuned a tone lower than the normal. Remodelled in four separate joints, no doubt by the members of the Hotteterre circle, this became the true bassoon, which arrived in Purcell's London under the name French basson. It is first named in a Lully score in 1674, but it may well have been in use ten or more years earlier."

265 "The baroque basson was used earlier and more often than surviving scores or parts show."
} 
Instrumentos de sopro não-especificados eram algumas vezes usados em seções ripieno, como sabemos pela indicação "somente cordas" antes de um movimento lento central; e em algumas orquestras alemãs todos os instrumentos de sopro podem ter tocado em concertos executados apenas por cordas e contínuo na Itália. Essa prática ad libitum não requeria partes diferentes daquelas destinadas aos intérpretes das cordas e do contínuo. (2012, p. 65, tradução nossa) $)^{266}$

Kopp (2012, p. 62, tradução nossa) afirma que há evidências de que o fagote barroco de quatro partes tenha surgido na França por volta de 1668, quando "Nicolas II Hotteterre tocou um 'basson' na capela real de Luís XIV"267. Com o tempo, o instrumento passou a ser mais amplamente utilizado na corte francesa e a tornar-se mais popular em outros territórios.

Assim como para outras madeiras barrocas, a figura de Lully é importante em relação à introdução e ao uso do fagote na orquestra.

Kopp explica que o instrumento era utilizado na corte francesa em diferentes contextos, tanto na ópera como na música de câmara e sacra reais, além de na Grande Écurie. O autor discorre sobre o uso lulliano dos instrumentos de sopro, informando também sobre suas aplicações alegóricas, incluindo a do fagote:

\begin{abstract}
Antes de Lully, os instrumentos de sopro eram ouvidos na ópera como grupos independentes que eram combinados raramente, se é que eram, com as cordas. Lully adicionou instrumentos de sopro e percussão aos conjuntos reais de violinos para suas obras cênicas, procurando evocar as associações da antiguidade clássica. $\mathrm{O}$ oboé era associado ao aulos grego, a pastores, a Baco e à alegria. O fagote, agrupado ao oboé (ou a um par de oboés) tomava algumas de suas associações. (2012, p. 66, tradução nossa $)^{268}$
\end{abstract}

\footnotetext{
266 "Unspecified wind instruments were sometimes used in ripieno sections, as we know from the 'strings only' before a slow middle movement; and in some German orchestras all available wind instruments may have joined in concertos which were performed only by strings and continuo in Italy. This ad libitum practice required no parts which differed from those supplied to string and continuo players."

267 "Nicolas II Hotteterre played 'basson' in the royal chapel of Louis XIV."

268 "Prior to Lully, wind instruments were heard in opera as self-contained consorts that were combined rarely, if at all, with strings. Lully added wind and percussion instruments to the royal violin ensembles for his stage works, seeking to evoke the associations of classical antiquity. The oboe was associated with the Greek aulos, shepherds, Bacchus, and jollity. The bassoon, grouped with the oboe (or a pair of oboes) as a suitable bass, took on some of its associations."
} 
Esse tipo de representação condiz perfeitamente com o tradicional uso pastoral das dulcianas.

Ao tornar o fagote o "baixo" dos oboés, Lully criou para ele um papel que se tornaria tradicional e que "seria ainda ouvido em sinfonias de Haydn" (KOPP, 2012, p. 66 , tradução nossa) ${ }^{269}$. Essa associação tornou-se muito forte, podendo ser encontrada em obras de diversos compositores do século XVII e XVIII. Nesses casos, como indicado por Kopp, é muito comum que o fagote seja conectado às alegorias representadas pelos oboés, como sendo, também alegoricamente, uma extensão dos mesmos.

É natural que o fagote e seus antecessores, devido a sua sonoridade grave, tenham sido, a partir do início do barroco, destinados à realização musical do contínuo, nas quais muitas vezes foram utilizados. $O$ uso do instrumento desempenhando esse papel (que ocorrerá intensamente até meados do século XVIII), quando visto a partir da questão alegórica, poderia levá-la à potencialização ou ao desaparecimento de seus efeitos. Ora, sendo amplamente usado em uma determinada obra, seu "efeito especial" poderia ser subtraído uma vez que deixasse de aparecer apenas em momentos alegoricamente oportunos e seu timbre se tornasse comum ou corriqueiro junto à peça. Nesse caso, seu uso se tornaria funcional junto ao desempenho do baixo-contínuo, sem foco em conexões alegóricas aparentes. Ao longo do período barroco, não seria possível negar que isso tenha acontecido por diversas vezes, assim como em relação a instrumentos graves que tenham sido tradicionalmente utilizados na execução do baixo. Não obstante, é visível que compositores, desde o início do barroco, utilizaram o fagote, mesmo que junto ao baixo-contínuo, devido ao seu potencial alegórico.

Stubbs clarifica essa questão ao citar informações contidas no prefácio de Rappresentatione di Anima e di Corpo, de Emilio del Cavallieri (um dos pioneiros da nova ópera italiana), publicada em Roma, em 1600, no qual lê-se que "o senhor Emilio é muito a favor da mudança da instrumentação de acordo com o afeto do cantor." $(1994, \text { p. } 88 \text {, tradução nossa })^{270}$. Logo, novamente prova-se a visão alegórica dos instrumentos, como detentores de afetos específicos que auxiliavam nos resultados catárticos da obra musical.

\footnotetext{
269 "that would still be heard in symphonies of Haydn."

270 "Signor Emilio would praise the changing of instrumentation to conform to the affetto of the singer."
} 
No mencionado Pomo d'oro de Cesti, o fagotto pelo qual pede a partitura executa uma linha de baixo-continuo comum a outros instrumentos, não tendo portanto, uma parte própria e exclusiva. No entanto, seu aparecimento em momentos muito específicos da obra (citados anteriormente) reforça a ideia de uma presença alegórica.

\section{ATTO PRIMO}

Scena I.

Reggia di Plutone.

Proserpina seguita dalle Belidi.

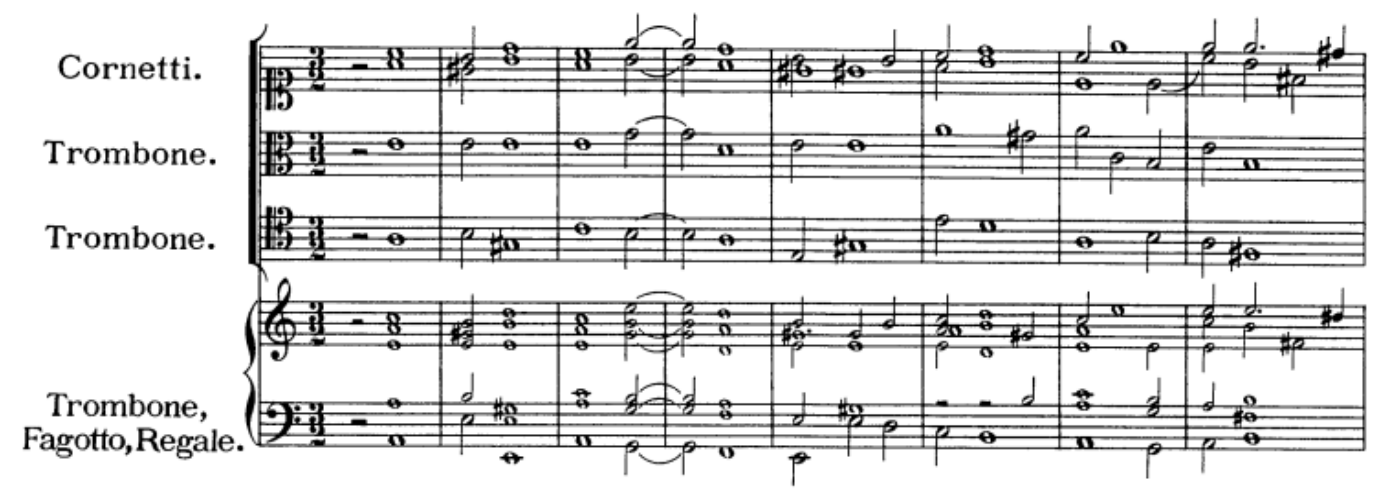

Fig. 52 - Cena de Il Pomo d’oro, de Cesti, na qual o fagote faz parte do baixo contínuo

No século XVIII ocorre um modo dual de visão do fagote, seja em relação a uma comparação dos tipos de instrumento então em uso ou aos diferentes timbres produzidos por um mesmo instrumento. Esse modo estará diretamente ligado à possível atribuição ao fagote de diferentes caracteres, o que, consequentemente, ecoará em seu uso alegórico.

Concentrando-se no território alemão, Dreyfus discute a questão dos diferentes instrumentos e dos termos usados para nomeá-los, comentando:

Na Alemanha dos dias de Bach, músicos tendiam a escolher uma entre duas atitudes opostas em relação ao fagote. A mais tradicional delas via o fagote como um instrumento a ser tolerado, um rude se algumas vezes necessário adjunto ao contingente do baixo, enquanto uma visão mais esclarecida via o 
fagote como um elegante, até mesmo aristocrático companheiro para o par de oboés da orquestra. (1987, p. 108, tradução nossa) ${ }^{271}$

\section{Dreyfus explica que o termo fagotto foi com frequência associado a algo} grosseiro e complementa a questão:

Nos primeiros anos do século XVIII (...) houve mudanças fundamentais na construção do fagote. Avanços técnicos em um novo instrumento de várias partes realizados por construtores como Johann Christoph Denner de Nüremberg terminaram por eliminar o mais antigo instrumento do tipo das dulcianas predominantes na Alemanha. Talvez o sucesso dos novos tipos de instrumento seja explicado, em parte, pela elevação social que o fagote experimentou subsequentemente. Esse novo fagote, identificado mais frequentemente como "basson" do que "fagott", superou seu baixo pedigree e, por associação com as elegantes práticas da orquestra de Lully, até assegurou uma respeitável posição social. A descrição à moda do fagote feita por Mattheson em Neu-Eröffnetes Orchestre de 1713, com seu professado viés galante, pode muito bem marcar um ponto de virada nas atitudes alemãs. (...)

De forma interessante, o (...) Kursgefasstes Musicalische Lexicon (1749) que (...) identificou o "fagot" como grosseiro cita Mattheson literalmente em relação ao mais elegante "basson" (...) Para alguns escritores, então, os dois nomes evocavam duas associações muito diferentes. (...)

Não fica claro, no entanto, se os compositores alemães do século XVIII sempre conceberam dois referenciais distintos para os termos fagotto e basson. O Lexicon de Walther (1732), por exemplo, afirma que "fagotto é o mesmo que basson" e prossegue dando a etimologia comum para o primeiro termo derivando de dois pedaços de madeira colocados juntos. É sobre o verbete fagott, aliás, que Walther cita Mattheson, que, em sua discussão do instrumento galante, chamou-o somente pelo nome "basson". Não obstante, instrumentos do tipo mais antigo continuaram a coexistir junto dos novos fagotes, especialmente durante os anos anteriores à chegada de Bach em Leipzig. É possível, portanto, esperar que um compositor como Bach, adaptando-se a vários estabelecimentos ligados à Igreja e à corte, tenha empregado os dois tipos de instrumento, mesmo com as distinções de nomenclatura não sendo completamente precisas." (1987, p. 111, tradução nossa) ${ }^{272}$

271 "In the Germany of Bach's day, musicians tended to hold one of two opposing attitudes toward the bassoon. The more traditional of these saw the bassoon as an instrument to be tolerated, a crude if sometimes necessary adjunct to the bass contingent, while a more enlightened view welcomed the bassoon as an elegant, even aristocratic companion to the pair of orchestral oboes."

272 "During the early years of the eighteenth century (...) there were fundamental changes in the construction of the bassoon. Technical advances in a new multijointed instrument pioneered by makers such as Johann Christoph Denner of Nürnberg eventually eliminated the older dulcian-type instrument prevalent in Germany. Perhaps the success of the newer instrumental types accounts, in part, for the elevation in social status which the bassoon subsequently experienced. This new bassoon, identified more often as "Basson" than "Fagott" overcame its lowly pedigree and, by association with the fashionable practices of Lully's orchestra, even secured a reputable social station. Mattheson's modish description of the bassoon in the Neu-eröffnetes Orthestre of 1713, with its professed galant bias, may well mark a turning point in German attitudes (...) 
Ficam claras, portanto, as diferentes visões direcionadas ao tipo de instrumento em uso no início do século XVIII, ao menos em relação à Alemanha, ainda que essa dualidade possa ter ocorrido também em outros lugares da Europa. Questões envolvendo nomenclaturas de instrumentos são, como já dito, não raro envoltas em confusões e contradições em diversos locais e idiomas mas, de qualquer modo, é evidente no período a distinção alemã entre um instrumento que é visto como rude e grosseiro e outro elegante e respeitável e que esse último, não só na Alemanha, tornar-se-á o instrumento principal. Nesse contexto, não seria impossível, por exemplo, que ambos tenham sido alegoricamente aplicados na música como símbolos de algo rústico ou refinado, respectivamente.

Como se vê na citação de Dreyfus, Mattheson parece focar suas informações sobre o novo basson e tende a apresentar uma visão positiva a seu respeito. $\mathrm{O}$ autor, ainda que classificando-o como tendo menor finesse do que os oboés, não o caracteriza como grosseiro e cita as dificuldades da boa e delicada execução de seu registro agudo (que, aliás, será amplamente visto como deveras importante e característico no decorrer do século XVIII).

No mesmo viés, Weigel, concordando com Mattheson, descreve um instrumento respeitável e de muito bom resultado em seu uso. A gravura mostra claramente o modelo barroco do instrumento, o fagote originalmente francês e mais recente do que as dulcianas, e o texto que o descreve tem caráter elogioso. Apesar disso, curiosamente, Weigel utiliza-se do termo fagott para nomear o instrumento.

A predominância do modelo de fagote francês nessas publicações pode ser vista como um dos anúncios de sua crescente aceitação e do futuro desuso das dulcianas.

\footnotetext{
Interestingly, (...) the Kurzgefasstes Musicalisches Lexicon (1749) (...) that identified the Fagot as "coarse" quotes Mattheson verbatim on the more elegant Basson (...) For some writers, then, the two names evoked two very different associations. (...)

It is not clear, however, that German composers of the eighteenth century always conceived of two distinct referents for the terms Fagotto and Basson. Walther's Lexikon (1732), for example, states that "Fagotto is just the same as Basson" and proceeds to give the common etymology for the former term deriving from two bound pieces of wood. It is under the entry Fagotto moreover, that Walther cites Mattheson, who, in his discussion of the galant instrument, had called it only by the name Basson. Nonetheless, instruments of the older type continued to coexist next to the newer bassoons, especially during the years before Bach arrived in Leipzig. One can therefore expect that a composer such as Bach, in adapting to various church and courtly establishments, would have employed both types of instruments, even if the distinction in nomenclature are not wholly accurate."
} 
Apesar da dualidade referente aos diferentes tipos de instrumento ser significativa, aquela voltada às diferenças dos timbres nas distintas regiões da extensão do fagote é ainda mais interessante e de alcance mais amplo, uma vez que continuará a caracterizar o instrumento por muito tempo, inclusive após o desaparecimento de seu antecessor.

Com o passar do tempo, o aprimoramento da construção e o desenvolvimento da técnica de execução do fagote permitiu que o registro agudo do instrumento fosse cada vez mais explorado. Assim, apesar de nunca abandonar totalmente o seu papel de baixo, garantido por seu poderoso registro grave, o fagote começará a ser cada vez mais explorado pelos compositores como uma relevante voz de tenor. Desse modo, seu uso orquestral é aos poucos expandido e ele passa a associar-se não só aos instrumentos graves do baixo-continuo mas também aos de registro médio, como as violas. Transitando entre esses registros, o fagote torna-se cada vez mais versátil, podendo servir a diversas funções.

Entretanto, o maior domínio de seu registro agudo não trouxe ao fagote apenas uma versatilidade de papéis relacionada a uma vasta extensão grave-agudo, mas também a uma diferença de timbres entre seus registros que podia dar-lhe mesmo personalidades distintas.

A região grave do instrumento, de uso até então mais comum e tradicional junto às linhas de baixo, apresentava sonoridade forte e penetrante, por vezes entendida até mesmo como brusca, muito adequada à rusticidade de danças campestres, por exemplo. Já na região aguda, o fagote do século XVIII mostrava sons de timbre mais arredondado, suave e cantabile, que seria diversas vezes, aliás, comparado ao da voz humana. O texto de Bethizy apresentado no capítulo 5.2, exemplifica essas características do instrumento.

O domínio da região aguda do fagote torna-se no século XVIII parte integrante do virtuosismo técnico a ele relacionado. São exemplos os trinta e oito concertos escritos por Vivaldi para o instrumento entre 1720 e 1741, que exigem grande domínio técnico com a tradicional escrita virtuosística do compositor, abrangendo grande parte de sua extensão. Kopp (2012, p. 84, tradução nossa) citando outro autor, escreve: 
Fertonani [autor de 'La musica strumentale di Antonio Vivaldi'] entendeu o fagote de Vivaldi como um 'fascinante e misterioso solista' com uma dupla personalidade. 'Ele ronca e palra nas profundezas de seu registro grave, mas é capaz de ímpetos de intensidade cantabiles, talvez inesperados, em sua região tenor (um efeito também visto em seus concertos para cello) ${ }^{\prime 273}$

Apesar da dualidade característica de seus diferentes registros, o fagote foi também por alguns considerado a partir de um caráter dominante, que englobava suas características distintas. As opiniões de D’Alembert e de Grétry (também mostradas no capítulo 5.2) descrevem o fagote, respectivamente, como instrumento da tristeza e do horror ou ainda lúgubre, suscetível ao patético e por isso um contrassenso à música alegre. As ideias desses autores mostram o fagote carregando essas características ainda em fins do século XVIII (o texto de Grétry data de 1789). De fato, muitas obras do Setecentos parecem caracterizar o fagote como um instrumento que tendia à representação da seriedade em diversos aspectos, além do medo, da ira, entre outras.

McCredie, abordando a ópera barroca produzida no norte da Alemanha, comenta:

\begin{abstract}
No que concerne a pintura de palavras, o fagote tinha uma ampla palheta de atmosferas e expressões. Kleefeld de fato comentou: "O caráter acre, insidioso dava à palheta do compositor as cores certas para representar infortúnio, ruína, culpa e expiação; ele era preferido em cenas de amor infeliz ou proibido, ou de adultério." Steffani havia usado fagotes para sublinhar as manobras e intrigas de pretendentes rivais, Keiser explorou seu timbre para enfatizar a angústia emocional de Octavia. (1964, p. 184, tradução nossa) $)^{274}$
\end{abstract}

Handel apresenta versatilidade em relação ao uso do fagote em suas obras, mas também parece ter contemplado o instrumento muitas vezes pelo viés da seriedade e dos afetos anteriormente mencionados. Em seu oratório Saul, por exemplo, os fagotes são empregados em momentos relevantes não somente junto ao contínuo, mas também em partes obbligato, dobrando vozes e compondo coros de

\footnotetext{
273 "Fertonani found Vivaldi's bassoon to be a 'fascinating and mysterious soloist' with a dual personality. 'It rumbles and gurgles in the depths of its low register, but is capable of cantabile rushes of intensity, perhaps unexpected, in its tenor range (an effect also seen in his cello concertos)'."

274 "As a means of tone-painting, the bassoon had a wide range of mood and expression. Kleefeld in fact commented - "Der dumpfe, schleichende Klangcharakter gab den Komponisten die rechte Farbe auf die Palette zum Malen von Missgeschick, Verhangnis, Schuld oder Suhne, mit Vorliebe erscheint es in den Szenen der unglücklichen oder unerlaubten Liebe, des Ehebruchs". Steffani had used bassoons to underline the manoeuvres and intrigues of rivals suitors, Keiser exploited its tone colour to emphasise the emotional distress of Octavia."
} 
sopros, entre outras funções. Chama a atenção o início do terceiro ato, sobre o qual comenta Langwill $(1975$, p. 86$)$ a respeito de um notável uso dos fagotes na cena entre Saul e a feiticeira de Endor, "onde dois fagotes soli acompanham a fantasmagórica voz sobre um baixo sustentado" 275 . O autor não se refere à ária da feiticeira, que também conta com uma linha de fagote predominantemente aguda em escrita coral com os oboés, mas à cena seguinte com o profeta Samuel, que fala a Saul. Durante a primeira frase cantada pela aparição, cujo texto diz "Por que me forçaste dos domínios da paz, de volta a esse mundo de aflições?", Samuel é acompanhado pelos dois fagotes. Apesar de curto, esse trecho musical é muito efeito, colorindo a cena da personagem que ressurge do além com uma sonoridade grave e expressiva, com um timbre até então não ouvido na obra.

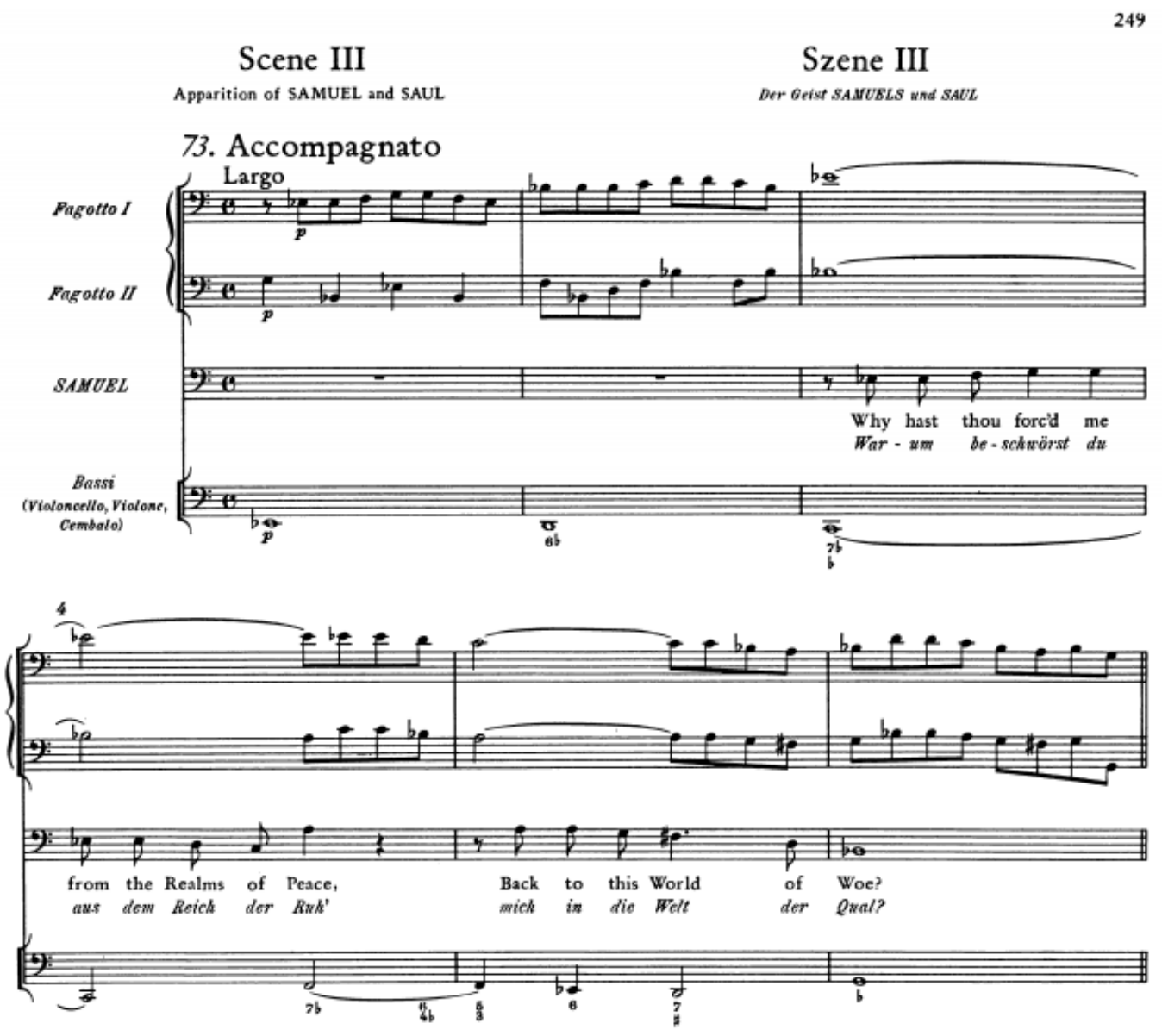

Fig. 53 - Recitativo da aparição de Samuel em Saul, HWV 53, de Handel. O profeta é acompanhado por fagotes

275 "Two bassoons soli accompany the ghostly voice over a sustained bass." 
A figura de Rameau é das mais importantes em relação ao uso orquestral do fagote na música barroca do século XVIII. Sadler afirma:

\begin{abstract}
O fagote é o instrumento cujo papel Rameau mais faz para transformar em relação a qualquer outro. Através de suas obras, ele naturalmente tem uma função importante dobrando a linha do baixo; mas a extensão através da qual é usado de forma independente dos basses cresce enormemente, até que no final de sua vida ele seja talvez o mais independente e versátil de seus instrumentos de sopro (...)

A grande e rápida expansão do papel do fagote [na obra de Rameau] chega no final dos anos de 1740 (...) O aumento do número de movimentos com fagotes completa ou amplamente independentes começa em 1747 (...). Desse período em diante, as funções desses fagotes independentes são mais variadas. Ainda há o papel tradicional como o baixo para o 'trio de hautbois', e há ainda as proeminentes linhas obbligato (agora mais numerosas). Novos papéis incluem o difundido uso do instrumento quase como outra viola, tocando bastantes linhas discretas no registro de tenor em danças, acompanhamentos, e mesmo em passagens fortes do tutti, e o extensivo uso dos fagotes em divisi. (1981-2, p. 59-60, tradução nossa) $)^{276}$
\end{abstract}

É inegável que Rameau legou algumas das mais interessantes partes para os fagotes na música dramática setecentista. A afirmação de Sadler discorre sobre o uso extenso e versátil do instrumento por parte do autor, em que assume diferentes papéis. De qualquer forma, a utilização frequente do registro agudo do fagote em diversas obras importantes do compositor é notável (Sadler comenta que "os instrumentos passam muito tempo acima do dó central, enquanto que o lá3 torna-se comum" ${ }^{277}$ ) e conectam sua música a uma sonoridade bastante original em relação ao uso do fagote.

Do ponto de vista alegórico, Rameau também utiliza o instrumento a partir de suas associações com a seriedade e com os afetos ligados ao horror, à tristeza e ao fúnebre. Duas de suas mais famosas árias são claros e excelentes exemplos disso:

\footnotetext{
276 "The bassoon is the instrument whose role Rameau does more to transform than any other. Throughout his works, it naturally has an important function doubling the bass line; but the extent to which it is used independ- ently of the basses grows enormously, until by the end of his life it is perhaps the most independent and versatile of his wind instruments (...)

The huge and rapid expansion in the bassoon's role comes in the later 1740 s (...) The rise in the number of movements with fully or largely independent bassoons begins in 1747 (...) From this period onwards, the functions of these independent bassoons are more varied. There is still the traditional role as bass to the 'trio des hautbois', and there are still the prominent solo obbligato lines (now more numerous). New roles include the widespread use of the instrument almost as another viola, playing fairly unobtrusive lines in the tenor register in dances, accompaniments, and even in loud tutti passages, and the extensive use of divided bassoons."

277 "the instruments now spend much time above the middle $c^{\prime}$, while $a^{\prime}$ becomes commonplace."
} 
tanto em Tristes apprêts, de Castor et Pollux, como em Lieux funestes, de Dardanus, os fagotes desempenham partes essenciais na potencialização dos afetos das composições. Em ambas as árias, o uso extenso de sua região aguda, especialmente quando suas linhas são executadas em uníssono por dois ou mais instrumentos, geram uma sonoridade ao mesmo tempo patética e assustadora.

Em Castor et Pollux, o texto da ária cantada por uma desolada Telaïre após a morte de seu amado Castor segue:

Tristes preparações, pálidas tochas, Dia mais terrível que as trevas, Astros lúgubres das tumbas, Não, eu não verei mais do que vossas claridades fúnebres.

Tu, que vês meu coração partido, Pai do Dia, ó Sol, ó meu Pai!

Eu não quero mais um bem que Castor perdeu, E eu renuncio à tua luz. ${ }^{278}$

A cena que ocorre, como indicado na partitura, em "um galpão arrumado para os funerais de Castor", mostra um momento de muita tristeza da personagem que canta suas dores ao falar das sombras daquele dia lúgubre, enquanto renuncia à luz do Sol, que não pode mais ser vista por Castor. A música, por sua vez, pinta o pesar de Telaïre não na forma do desespero e descontrole, mas de maneira nobre, contida, até mesmo processional, apesar de muito profunda.

A partitura mostra uma linha específica de bassons que tocam um ostinato de arpejos quase sempre em sua região aguda. Apesar de simples, a parte dos fagotes é muito efetiva, soando elegante e surpreendentemente como trompas à distância. De certa forma, essa sua utilização poderia resumir em si própria muitas das associações

\footnotetext{
278 "Tristes apprêts, pâles flambeaux, Jour plus affreux que les ténèbres, Astre lúgubres des tombeaux, Non, je ne verrais plus que vos clartés fúnebres.

Toi, qui vois mon coeur éperdu, Père du jour, ô Soleil, ô mon Père! Je ne veux plus d'un bien que Castor a perdu, Et je renonce à ta lumière."
} 
já citadas: aqui, o fagote é lúgubre, bem representando a dor e a angústia provocadas pela morte através de seus lamentosos, "extraterrenos" sons agudos, ainda que de uma forma elegante, pomposa ou "orgulhosa", utilizando-se do adjetivo proposto por Mattheson.

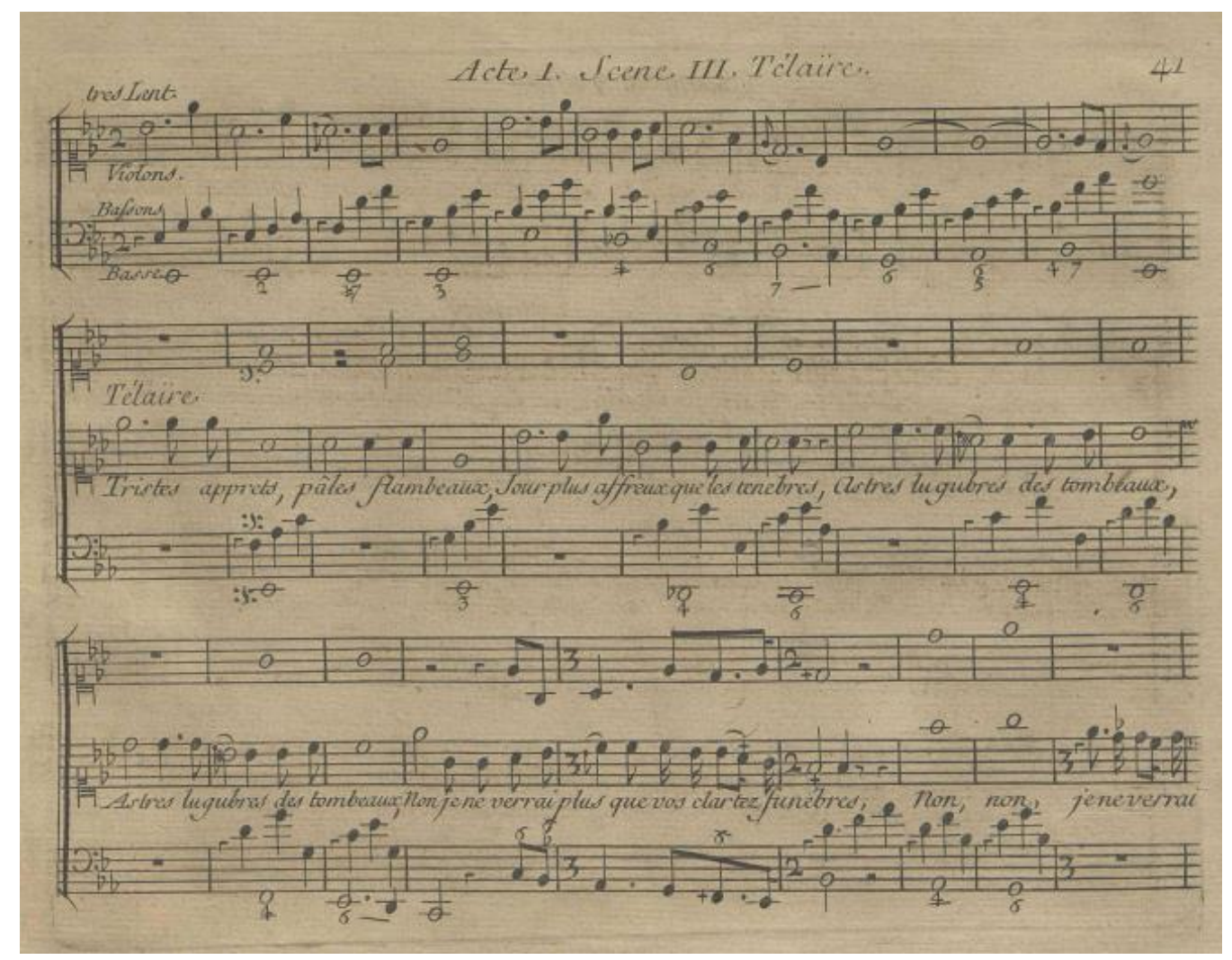

Fig. 54 - Tristes apprêts, em Castor et Pollux, de Rameau. Os fagotes tocam um ostinato próprio

O quarto ato da versão de 1744 de Dardanus inicia-se com uma ária cantada pela personagem título que encontra-se na prisão. O texto da ária diz:

Lugares funestos, onde tudo respira a vergonha e a dor, Do desespero, sombrio e cruel império, O horror que vosso aspecto me inspira, É o menor dos males que rasgam meu coração.

O objeto de tanto amor, a beleza à qual estou atado O cetro que perco, o prêmio de meu trabalho, Tudo será de meu rival,

Enquanto, em meio aos ferros, só tenho minha coragem, Que não basta para me livrar de meus males. ${ }^{279}$

279 "Lieux funeste, où tout respire la honte et la douleur, 
A música na tonalidade de fá menor é extremamente direta na representação do desespero de Dardanus, repleta de dissonâncias e harmonias inesperadas. A parte dos fagotes é dividida com tailles e haute-contres (instrumentos de registro médioagudo, como as violas) tocando a mesma linha, mas por se manter numa região predominantemente aguda, o timbre dos fagotes é nela ressaltado e, de certo modo, mais evidente que dos outros instrumentos. Além disso, o compositor indica que em determinados momentos a parte deveria ser tocada apenas pelos fagotes. A importância dada por Rameau à linha com esses instrumentos (que, aliás, é a primeira a ser ouvida na ária) evidencia a escolha alegórica dos fagotes na representação do horror e da angústia da personagem.

É também interessante notar-se através dessas árias que a ideia da lugubridade associada ao fagote não parecia estar somente ligada à sua sonoridade grave, acompanhando o instrumento em um contexto mais amplo, podendo ir além dos aspectos relacionados aos seus registros.

Du désespoir, sombre et cruel empire, L'horreur que votre aspect $m$ 'inspire, Est le moindre des maux qui déchirent mon coeur.

L'objet de tant d'amour, la beauté qui m'engage Le sceptre que je perds, ce prix de mes travaux, Tout va de mon rival devenir le partage, Tandis que dans les fers, je n'ai que mon courage, Qui suffit à peine à mes maux." 


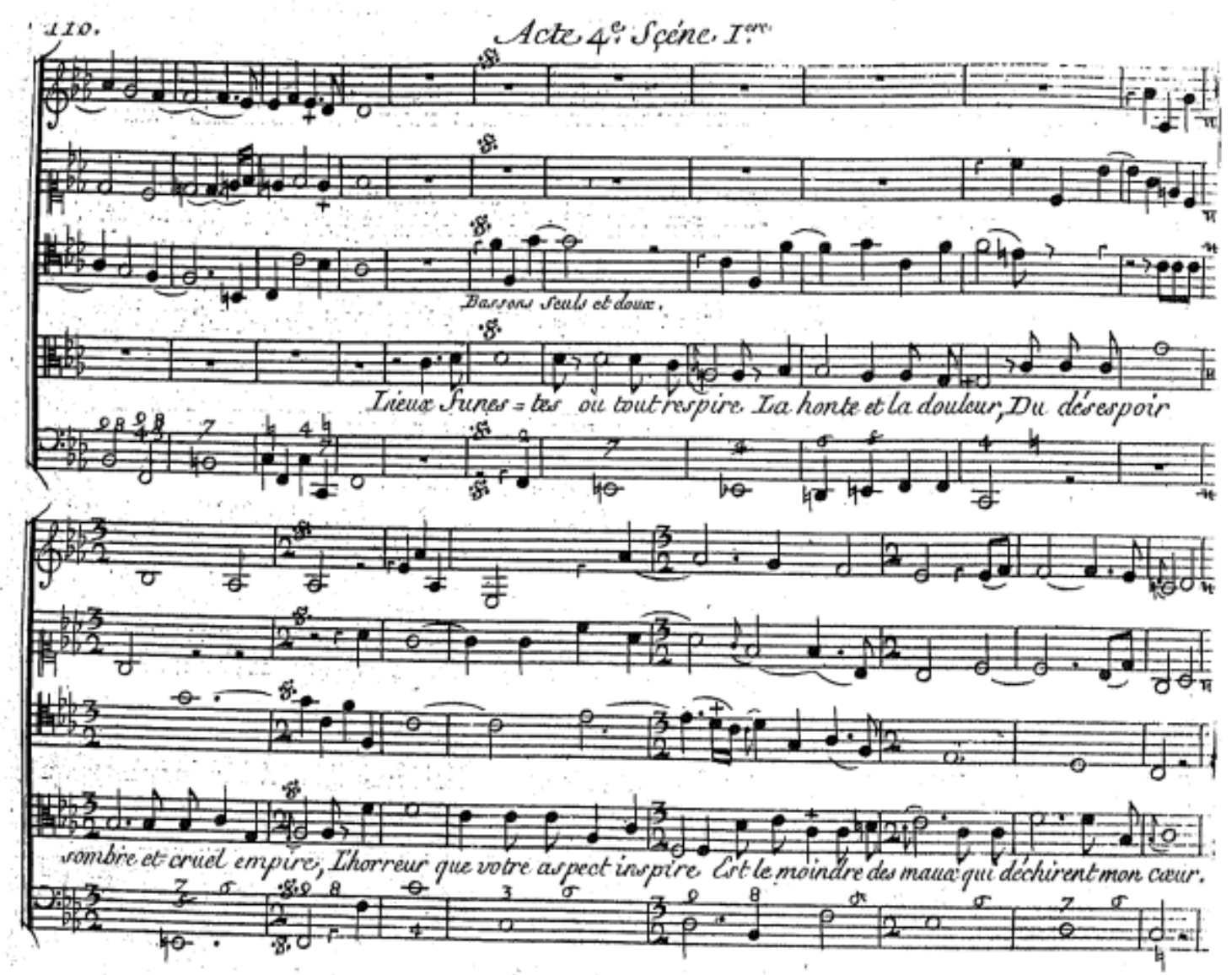

Fig. 55 - Excerto de Lieux funestes, no quarto ato de Dardanus (versão de 1744) de Rameau. A linha de fagotes é vista no terceiro pentagrama

A partir da segunda metade do século XVIII, com as transformações musicais que levarão o estilo galante ao classicismo, o tratamento dado ao fagote também será transformado. De forma geral, o instrumento ganha cada vez mais versatilidade. Ele continua a dobrar partes de baixo, como pode se ver ainda nas primeiras sinfonias de Haydn e Mozart, mas partes individuais escritas para os fagotes na música orquestral tornar-se-ão mais comuns. Na formação instrumental que começa a se padronizar em direção à orquestra clássica, o fagote assumirá o posto de baixo do naipe de madeiras, mas isso não o impedirá de desempenhar também papéis de tenor e alto. Além disso, a versatilidade do instrumento dará a ele múltiplas funções na orquestra como, por exemplo, apresentar melodias e dobrar vozes com diversos instrumentos. Langwill comenta: 
Ralph Hill [em The Symphony (Londres, 1940)] refere-se ao hábito de Haydn de usar o fagote para reforçar as partes mais agudas ao invés de sustentar a fundação harmônica do grupo de sopros. Mesmo em suas obras mais tardias o fagote é orquestrado como instrumento tenor ou alto, negligenciando quase que totalmente sua oitava mais grave. $(1975, \text { p. } 88 \text {, tradução nossa })^{280}$

Kopp explica que "como Haydn, Mozart recorreu ao fagote como uma cor orquestral insubstituível e um frequente colaborador em solos. Mais de 150 de suas obras especificam o fagote e ele provavelmente dobrava a linha de baixo em outras." (2012, p. 104, tradução nossa) ${ }^{281}$.

O autor refere-se também a uma forma de orquestração que se tornaria famosa:

\begin{abstract}
Compositores gostaram do que ouviram do registro de tenor do fagote - ele se tornou o instrumento favorito para dobrar cantores, violinos ou as madeiras agudas na oitava mais grave (ou por vezes duas oitavas abaixo). Esse tipo de orquestração - típico dos compositores clássicos vienenses mas também visto em todo lugar - dava à melodia em destaque uma vívida, "sombreada", quase palpável presença e à textura orquestral uma nova ilusão de profundidade ou espaço tridimensional.

(...) a voz de tenor do fagote assumiu um papel discreto porém crucial na criação da sensação tridimensional da orquestração clássica Vienense. A dobra de violinos na oitava mais grave era parte do som clássico vienense essencial - um padrão musical em não apenas em uma oitava, mas também em duas ou frequentemente em três, chamado por alguns autores de 'uníssono vienense'. (2012, p. 87, 103, tradução nossa) $)^{282}$
\end{abstract}

Em relação ao seu uso alegórico na segunda metade do século XVIII, nota-se também uma maior variedade. Como visto nas palavras de Schubart, o fagote passou a

\footnotetext{
280 "Ralph Hill refers to Haydn's habit of using the bassoon to reinforce the upper parts rather than to supply the harmonic foundation of the wind ensemble. Even in his very last works the bassoon is scored as a tenor or alto instrument to the almost entire neglect of its lower actave."

281 "Like Haydn, Mozart drew upon the bassoon as an irreplaceable orchestral color and a frequent contributor of solo lines. More than 150 of his works specify bassoon, and it probably doubled the bass line in others."

282 "Composers liked what they heard of the tenor register of the bassoon - it became the favored instrument for doubling singers, violins, or the treble woodwinds at the lower octave (or sometimes the double octave). This sort of scoring - typical of Viennese classical composers but also seen elsewhere gave the featured melody a vivid, 'shadowed', almost palpable presence and the orchestral texture a new illusion of depth or three-dimensional space.

(...) the bassoon's tenor voice assumed a discreet but crucial role in creating the three-dimensional feel of Viennese classical orchestration. Doubling the violin at the lower octave was part of the essential Viennese Classic sound - a musical pattern not in only one octave, but in two or often three, called by some authors the "Wiener unisono'."
} 
se prestar aos mais diversos papéis, que poderiam continuar as tradições anteriores mas também trazer novidades.

Gluck usou o fagote com associações já vistas na primeira metade do XVIII em algumas de suas obras mais importantes:

Nas cenas nos Campos Elísios de Orfeo [de Gluck] (1762), o fagote desempenha um papel importante, por vezes solístico, ao expressar os sentimentos lamentosos e melancólicos de Orfeu, empregando o som expressivo do registro agudo (até o sol3); na última cena da obra o fagote está quase que completamente em uníssono com as violas; ele ecoa os oboés (ato III, cena I). O fagote é pareado aos chalumeaux para evocar uma melancolia silvestre e uma voz pavorosa de deuses subterrâneos (Alceste, ato II, cena 2). Gluck usou sua cor para expressar tristeza e melancolia no ballet Don Juan (no. 21, saída da estátua). (Kopp, 2012, p. 102-103, tradução nossa) $)^{283}$

Já Haydn, em seu refinado humor característico, pode ter aproveitado o instrumento por outro viés, como comenta Langwill (1975, p. 88, tradução nossa):

Haydn tinha grande afeição pelo fagote e 'apesar de ter negligenciado inteiramente sua capacidade de retratar a tragédia, ele se regozijou em suas características alegres, amáveis e cômicas' ${ }^{284}$

Prout reafirmou as potencialidades cômicas do instrumento já no repertório clássico:

Para a produção de efeitos grotescos [vistos aqui pelo viés do risível], nenhum instrumento se iguala, ou mesmo se aproxima, do fagote; ele pode ser de fato chamado de o palhaço da orquestra. O bom e velho "Pai Haydn", repleto como era de humor, parece ter sido o primeiro a perceber isso, e muitas passagens cômicas para o fagote serão encontradas em suas sinfonias. Será suficiente referir-se ao dó1, fortissimo, para os dois fagotes, complemente desacompanhados, no movimento lento da Sinfonia em Ré (No. 2 da "Série Salomon") [o autor se refere à Sinfonia no. 93, composta em 1791], como uma ilustração." (1902, p. 44, tradução nossa) ${ }^{285}$

\footnotetext{
283 "In the Elysian scenes of Orfeo (1762) the bassoon plays an important, sometimes soloistic role in expressing the woeful and wistful feelings of Orpheus, employing the expressive sound of the high range (to G4); in the last scene of the work the bassoon is almost completely in unison with the violas; it echoes the oboes in Orfeo (iii, 1). The bassoon is coupled with the chalumeaux to evoke a sylvan gloom and ghastly voices of subterranean gods (Alceste, ii, 2). Gluck used its colour to express gloom and melancholy in the ballet Don Juan (no. 21, exit of the statue)."

284 "Haydn had a great affection for the bassoon and 'though he neglected entirely its capacity to portray tragedy, he revelled in its gay, lovable and laughable characteristics'."

285 "For the production of grotesque effects no instrument equals, or even approaches, the bassoon; it may indeed be called the clown of the orchestra. Good old 'Father Haydn', overflowing as he was with
} 


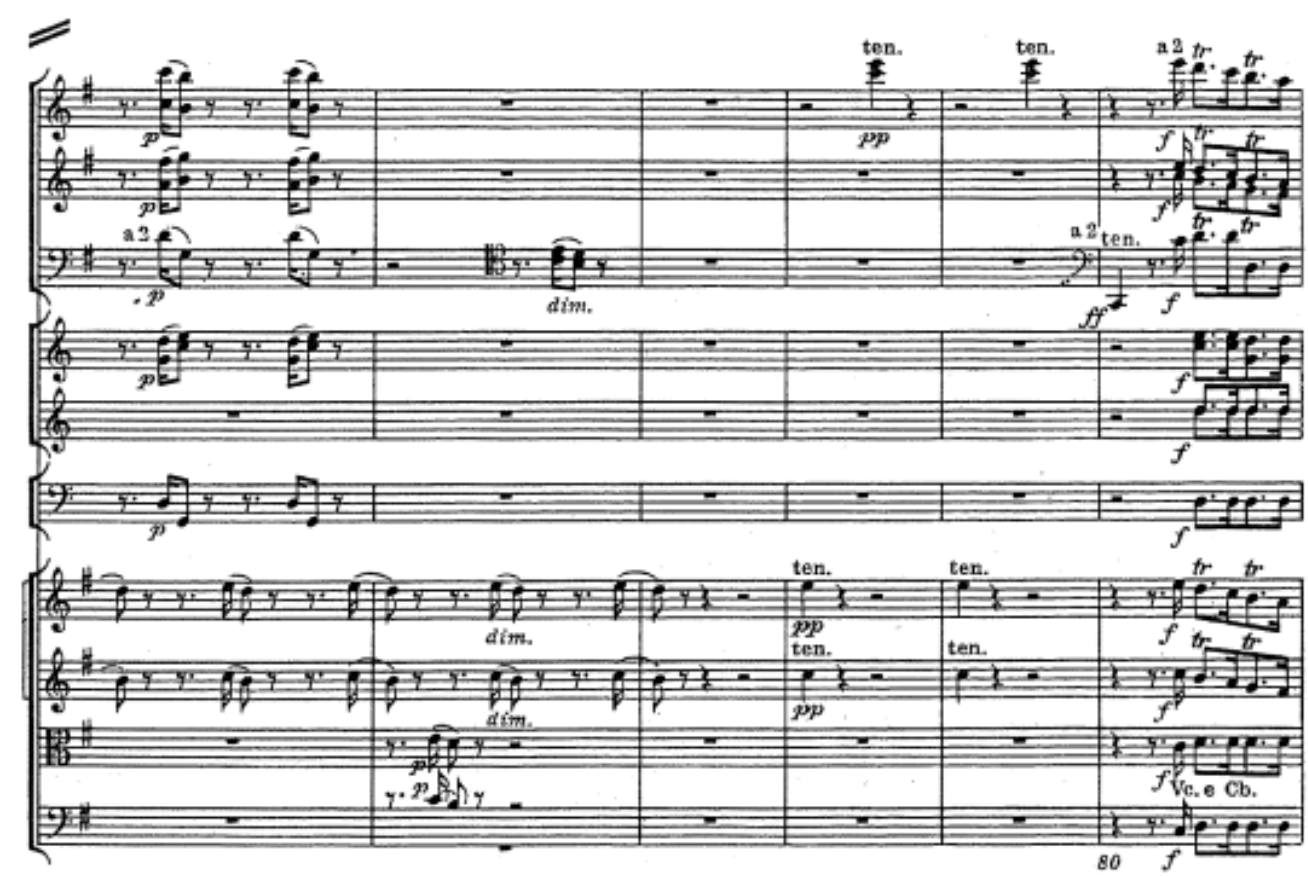

Fig. 56 - Trecho da Sinfonia no. 93 de Haydn mencionado por Prout. Os fagotes ocupam o terceiro pentagrama

Apesar de toda versatilidade do fagote no século XVIII, especialmente na segunda metade do período, não é possível afirmar que a visão cômica do instrumento tenha prevalecido sobre outras nessa época. Esse aspecto do fagote parece ter sido mais explorado a partir do século XIX.

De qualquer forma, o que chama mais a atenção em relação ao uso alegórico do instrumento ao longo de todo o século XVIII é a dualidade que parece acompanhálo com frequência e que pode ser vista como uma de suas características mais notáveis. Afinal, o fagote pôde ser contemplado como rústico ou sofisticado, cômico ou trágico, baixo ou elevado, lúgubre ou amoroso. De fato, um caso exemplar de versatilidade.

fun, seems to have been the first to perceive this, and many comic passages for the bassoon will be found in his symphonies. It will suffice to refer to the $C$ for the two bassoons, entirely unaccompanied, in the slow movement of the Symphony in D (No. 2 of the 'Salomon Set') as an illustration." 


\title{
6 A ALEGORIA INSTRUMENTAL NO FIM DO SÉCULO XVIII E INÍCIO DO XIX
}

\subsection{A orquestra clássica e a continuação de tradições}

Em fins do século XVIII, a maioria dos importantes grupos orquestrais europeus adquirira uma formação instrumental padronizada, somando cordas, sopros e tímpanos, após décadas de um processo que levaria a essa situação:

\begin{abstract}
A transformação dos grupos instrumentais em orquestras, que começou na França em meados do século XVII, espalhou-se rapidamente para o resto da Europa, de forma que por volta de 1740 quase toda grande cidade e toda corte importante tinha um conjunto que chamava a si mesmo, ou poderia ser chamado, de uma orquestra. O período seguinte - por volta de 1740 a 1815 - foi um tempo de consolidação. A instrumentação, organização, papéis sociais, e práticas de performance da orquestra mudou comparativamente pouco durante esse período. Em retrospecto, as orquestras da segunda metade do século XVIII e início do XIX podem coletivamente ser chamadas de "a orquestra clássica" - clássica porque representavam a primeira configuração orquestral que era tanto estável como normativa. Além disso, essas foram as orquestras para as quais Haydn, Mozart e Beethoven compuseram suas sinfonias, concertos e óperas; como suas obras tornaram-se "clássicas", sua orquestra também se tornou. (SPITZER E ZASLAW, 2004, p. 307, tradução nossa) ${ }^{286}$
\end{abstract}

O período que levou à formação da orquestra clássica viu uma significativa diferenciação do uso dos instrumentos bem como de suas relações dentro do grupo:

\begin{abstract}
Apesar da organização básica da orquestra clássica ter se mantido muito estável entre 1740 e 1815, uma tendência pode ser vista na direção de um aumento na diferenciação dos grupos instrumentais. Oboés, flautas e clarinetas foram separados em seções, cada um com um par de intérpretes especializados. Enquanto esse variado grupo de sopros continuou a funcionar como um coro, dobrando partes de cordas e sustentando
\end{abstract}

\footnotetext{
286 "The transformation of instrumental ensembles into orchestras, which began in France around the middle of the seventeenth century, spread rapidly to the rest of Europe, so that by 1740 almost every large city and every important court had an ensemble that called itself, or could be called, an orchestra. The ensuing period - from about 1740 to about 1815 - was a time of consolidation. The instrumentation, organization, social roles, and performance practices of the orchestra changed comparatively little during this period. In retrospect the orchestras of the second half of the eighteenth century and the early nineteenth century can be referred to collectively as the 'classical orchestra' classical in that they represented the first orchestral configuration that was both stable and normative. In addiction, these were the orchestras for which Haydn, Mozart, and Beethoven composed their symphonies, concertos, and operas; as their works were turned into 'classics', their orchestra became 'classical'."
} 
harmonias, cada vez mais durante a segunda metade do século XVIII os instrumentos que o constituíam serviram, separadamente e em variadas combinações, para adicionar cores à paleta orquestral. Cellos e fagotes diferenciaram-se do basso e cada vez mais receberam suas próprias partes, cellos como uma voz obbligato no registro de tenor, fagotes como tenores solistas ou como o baixo do coro de sopros. Várias partituras reduzidas tornaram-se familiares, por exemplo a orquestração de cordas a três partes que combinava primeiros e segundos violinos ou omitia violas, ou partituras nas quais o basso não estava presente e as violas ou mesmo os segundo violinos tomavam a linha do baixo. Orquestração a quatro partes permaneceu a norma, mas os outros instrumentos não eram mais para "preenchimento e dobra": eles eram uma parte essencial e indispensável da orquestra. (SPITZER E ZASLAW, 2004, p. 316, tradução nossa) ${ }^{287}$

Assim, vê-se que os citados instrumentos de sopro passaram a constituir o corpo básico e fundamental da orquestra, deixando para trás suas tantas participações eventuais no grupo como instrumentos de uso pontual ou extraordinário. Na nova padronização instrumental da orquestra, eles estariam sempre presentes. Essa presença constante e, consequentemente, comum somada às diferentes maneiras de sua utilização nos novos "efeitos" particulares à música orquestral da segunda metade do século XVIII podem trazer questionamentos a respeito da manutenção do uso dos instrumentos de forma alegórica e de até que ponto ela teria continuado a existir.

Como comentado algumas vezes, a presença comum de um instrumento dentro do grupo orquestral poderia torná-la corriqueira e fazer com que, de certo modo, perdesse parte de seu potencial alegórico e catártico como sendo um "efeito especial" aplicado à música. A família dos violinos, por exemplo, que no começo do século XVII poderia causar sensações muito novas aos ouvintes, tornou-se padronizada e comum para os ouvidos das décadas seguintes, constituindo-se na base da orquestra e fazendo-se constantemente presente. Ainda que extremamente expressiva, ela

\footnotetext{
287 "Although the basic organization of the classical orchestra remained pretty much stable between 1740 and 1815, a trend can be discerned toward increased differentiation of instrumental groups. Oboes, flutes, and clarinets were separated into sections, each with pairs of specialist performers. While this variegated wind group continued to function as a choir, doubling string parts and sustaining harmonies, increasingly during the second half of the eighteenth century its constituent instruments served, separately and in various combinations, to add coloristic highlights to orchestral palettes. Cellos and bassoons were differentiated from the basso and increasingly received their own parts, cellos as an obbligato voice in the tenor register, bassoons as tenor soloists or as the bass of the wind choir. Various reduced scorings became familiar, for example three-part string scorings that combined first and second violins or omitted the violas, or scorings in which the basso dropped out and the violas or even the second violins took the bass line. Four-part scoring remained the norm, but the other instruments were no longer 'filler and doubling': they were an essential and indispensible part of the orchestra."
} 
perdera seu potencial de novidade ou raridade na música, potencial esse que continuou a fazer parte do uso dos sopros, que em sua maioria ainda não possuíam um lugar fixo na orquestra. Uma vez que esse lugar fixo foi adquirido, pode-se pensar na possibilidade de que também os sopros passariam pelo mesmo processo de "naturalização" vivenciados pelas cordas da orquestra e que a constância de sua presença terminaria por diminuir a potencialidade de seu uso alegórico.

Outra questão diz respeito às novas maneiras de utilização dos instrumentos de sopro dentro do contexto orquestral setecentista, que poderia ter provocado uma mudança de concepção de seu papel em meio ao grupo, como comentam Spitzer e Zaslaw (2004, p. 483, tradução nossa):

(...) novos efeitos de variedade e nuance foram inventados e refinados ao longo dos séculos XVII e XVIII. Os primeiros baseavam-se principalmente nas cordas, mas conforme mais instrumentos de sopro se tornaram disponíveis e intérpretes mais tecnicamente capazes, compositores descobriram efeitos impressionantes de variedade tímbrica e nuance que poderiam ser criados com os sopros. Onde compositores anteriores tinham usado um sopro solista, uma textura e um timbre para cada peça, compositores tardios utilizaram-se de diversos solistas para criar um caleidoscópio de timbres e texturas. Além disso, os instrumentos de sopro tenderam a perder suas associações extramusicais; agora eles eram usados por seus timbres e suas capacidades técnicas. ${ }^{288}$

Portanto, as novas configurações orquestrais dos instrumentos de sopro teriam contribuído para afastá-los de seus tradicionais papéis alegóricos. No entanto, ainda que isso seja um fato, seria difícil acreditar que uma tradição tão forte tenha se esvaído completamente da música composta para a orquestra clássica, e existem evidências em escritos e nas próprias composições mostrando que, na verdade, o uso alegórico não desapareceu.

Os tratadistas citados no capítulo 5.2, por exemplo, cujos textos foram publicados já no final do século XVIII, ainda falam dos instrumentos como detentores de caráter e do efeito que causavam nas composições quando usados alegoricamente

\footnotetext{
288 "new effects of variety and nuance were invented and refined over the course of the seventeenth and eighteenth centuries. The earliest relied mainly on strings, but as more wind instruments became available and as players grew more skillful, composers discovered strinking effects of timbral variety and nuance that could be created with winds. Where earlier composers had used one wind soloist, one texture, and one timbre per number, later composers called on several soloists to create a kaleidoscope of timbres and textures. In addiction, wind instruments tended to lose their extramusical associations; now they were used for their timbres and their technical capabilities."
} 
através desse seu viés. Outros autores também reforçarão essa ideia em escritos do mesmo período.

Dolan (2013, p. 155, tradução nossa) comenta a respeito da manutenção do uso dos instrumentos relacionado a seu caráter:

\begin{abstract}
A noção de caráter instrumental não era, é claro, totalmente nova: instrumentos tinham muitas associações poderosas muito antes da consolidação da orquestra. O nascimento de um discurso de caráter musical é fácil de ser negligenciado. Em The Birth of the Orchestra de John Spitzer e Neal Zaslaw, por exemplo, os autores descrevem como vários gestos orquestrais - uníssonos, trêmulos, efeitos de eco - começaram como gestos explicitamente dramáticos, normalmente em contextos operísticos, nos quais o "significado" do gesto era ilustrado pelo texto e pela ação. "Conforme se tornaram mais familiares", Spitzer e Zaslaw escrevem, "efeitos orquestrais tenderam a soltar-se de suas associações com contexto, de modo que na época de Mozart eles tinham vindo a significar a orquestra em si, sua unidade, grandeza, variedade e nuance." Mais uma vez, essa narrativa reflete a noção, articulada mais fortemente por Carl Dahlhaus, de que o fim do século XVIII testemunhara a ascenção da música "abstrata": música que era puramente "sobre" música; música que rejeitava formas miméticas de significado. Mas isso ignora um estágio intermediário crucial entre o extramusical e o "absoluto". Os caracteres que os autores do fim do século XVIII e do XIX atribuíram aos instrumentos de sopro surgem através da internalização do que tinham anteriormente sido associações. ${ }^{289}$
\end{abstract}

\title{
Concentrando-se nos sopros de metal, a autora continua:
}

Trompetes e tambores, por exemplo, em fins do século XVIII ainda eram intimamente conectados com o militar, e tinham usos claramente definidos fora de contextos "puramente musicais": exércitos usavam o trompete para comunicar-se entre seus batalhões, com seus vários toque tendo funções claras como soar a arrancada e a retirada. Na orquestra, essa função militar tornou-se seu caráter: ela sinalizava vitória e alegria marciais mais comumente. A trompa era da mesma forma uma ferramenta de comunicação no contexto da caça. Entretanto, porque a trompa era um membro da orquestra há tempos, ela levava um tipo de vida dupla:

289 "The notion of instrumental character was not, of course, wholly new: instruments had many powerful associations long before the consolidation of the orchestra. The birth of a discourse of musical character is easy to overlook. In John Spitzer and Neal Zaslaw's The Birth of the Orchestra, for example, the authors describe how various orchestral gestures - unions, tremolos, echo effects - started as explicitly dramatic gestures, usually in operatic contexts, where the 'meaning' of the gesture was illustrated by the text and action. 'As they became more familiar,' Spitzer and Zaslaw write, 'orchestral effects tended to loosen their associations with context, so that by Mozart's time they had come to signify the orchestra itself, its unity, grandeur, variety, and nuance.' Once again, this narrative reflects the notion, articulated most powerfully by Carl Dahlhaus, that the late eighteenth century witnessed the rise of 'abstract' music: music that was purely 'about' music; music that rejected mimetic forms of meaning. But this ignores a crucial middle stage between the extra-musical and the 'absolute'. The characters which late eighteenth- and nineteenth-century authors attributed to wind instruments arose through the internalization of what had previously been associations." 
compositores podiam usá-la para suporte harmônico ao fundo, utilizando o calor de seu som para criar uma sonoridade orquestral plena; mas quando era trazida à frente, ela mais uma vez ostentava suas origens de instrumento de caça. O trombone, igualmente, era um instrumento funcional, mas um que veio de um contexto muito diferente: antes de se tornar um membro regular da orquestra (o que não ocorreu, claro, até o século XIX), ele era usado na música sacra, amplamente na dobra de linhas vocais, onde servia como um auxiliar da entonação, ajudando cantores a manter sua afinação, sem ênfase específica nas particularidades de sua sonoridade. Compositores tardios, em particular Gluck e Mozart, começaram a abordar o instrumento por suas propriedades emotivas: fora do contexto da igreja, o instrumento tinha o poder de sinalizar autoridade sacra. (DOLAN, 2013, p. 155-156, tradução nossa) ${ }^{290}$

Vale ressaltar que o uso que Mozart faz do trombone em suas óperas, como em Don Giovanni, é um dos grandes exemplos de aplicação alegórica de um instrumento na música durante o século XVIII. O compositor utiliza trombones em poucos momentos, muito específicos e pontuais, nos quais a simbologia sacra e extraterrena dos instrumentos ajuda a elevar o nível dramático das cenas a um mais elevado padrão catártico. O fato de Mozart ter pedido pelos instrumentos em apenas determinados momentos, fazendo questão de sua presença ali, mostra a preocupação do compositor com o uso de seus valores alegóricos.

Dolan cita também outros autores que, já no fim do século XVIII, falavam da importância do uso dos instrumentos de sopro de acordo com seu caráter específico, e também dos problemas causados quando os mesmos eram utilizados fora desse campo:

\footnotetext{
290 "Trumpets and drums, for example, in the late eighteenth century were still intimately connected with the military, and had clearly defined uses outside of 'purely musical' contexts: armies used the trumpet to communicate between its sections, with its various calls having clear functions such as sounding the charge and retreat. Within the orchestra, this military function became its character: it signaled martial victory and joy more generally. The horn was likewise a tool of communication in the context of the hunt. However, because the horn was a long-time member of the orchestra, it led a kind of double life: composers could use it for harmonic support in the background, using the warmth of its tone to create a full orchestral sonority; but when it was brought to the foreground, it once again flaunted its origin as a hunting instrument. The trombone, likewise, was a functional instrument, but one that came out of a very different context: before becoming a regular member of the orchestra (which it did not, of course, until the nineteenth century), it was used in sacred music, largely to double vocal lines, where it served as an intonation aid, helping singers maintain their pitch, without specific emphasis on the particularities of its sonority. Later composers, in particular Gluck and Mozart, began to draw upon the instrument for its emotive properties: outside of the contexto of the church, the instrument had the power to signal sacred authority."
} 
Quando o trompetista Johann Ernst Altenburg publicou seu Versuch einer Anleitung zu heroisch-musikalischen Trompeter und Pauken-Kunst em 1795 - apesar de escrito mais de um quarto de século antes - ele discutiu o trompete, primordialmente, como um instrumento militar. Altenburg enfatizou que o poder do trompete para instigar medo nos corações do inimigo e inspirar a alegria da vitória requeria regulamentação cuidadosa. Apenas aqueles trompetistas que tinham de fato servido em campanhas militares deveriam ter alunos, ele argumentava, e apenas um por vez. Altenburg incluiu longas cotações de vários editais emitidos no fim do século XVII e começo do XVIII proibindo trompetistas de tocar em funções nãomilitares (i.e., saltitar com malabaristas, comediantes, e assim por diante). Sublinhando esse desejo por controle estava um ansiedade de que uma mudança na função e contexto do instrumento iria por fim mudar sua identidade. Ou seja, contanto que os trompetes se comportassem como trompetes, eles poderiam comandar um poder expressivo particular, mas aquele poder minguava quando os trompetes eram colocados para outros usos. (DOLAN, 2013, p. 156-157, tradução nossa) $)^{291}$

As opiniões de Altenburg são interessantes por mostrar as preocupações a respeito do uso de seu instrumento provenientes de um músico prático (ele era compositor, organista e trompetista), e não apenas teórico, mostrando que questões dessa natureza não teriam ficado restritas às páginas de tratados e teriam relevância em meio ao fazer musical.

Em 1798, Carl Zelter publicou um ensaio no Allgemeine musikalische Zeitung, intitulado "Bescheidene Anfragen an die modernsten Komponisten und Virtuosen." Cada questão abordava diferentes formas de abuso instrumental: na primeira, sobre a flauta, Zelter recorda que houve "um tempo quando ela não era apenas chamada mas de fato era o mais doce dos instrumentos, quando era o modelo e ideal ao qual toda sonoridade doce seria comparada. Agora é diferente. Compositores modernos normalmente escrevem para o instrumento de modo que ele deva guinchar." Na segunda de suas "questões modestas", ele perguntou, "Por que a maioria dos compositores modernos escrevem para a trompa, claramente contra sua natureza e beleza intrínseca, como para trompete, e para os trompetes, não raramente e contra sua natureza, como para as trompas?" Zelter

291 "When the trumpeter Johann Ernst Altenburg published his Versuch einer Anleitung zu heroischmusikalischen Trompeter- und Pauker-Kunst in 1795 - though written over a quarter century earlier - he discussed the trumpet, first and foremost, as a military instrument. Altenburg emphasized that the trumpet's power to instill fear in the hearts of the enemy and inspire the joys of victory required careful regulation. Only those trumpeters who had actually served in military campaigns should take on students, he argued, and only one student at a time. Altenburg included lengthy quotations from various edicts issued in the late seventeenth and early eighteenth centuries forbidding trumpeters from playing in non-military functions (i.e., cavorting with jugglers, comedians, and so on). Underlying this desire for control was an anxiety that a change in the instrument's function and context would ultimately change its identity. To put it another way, as long as trumpets behaved as trumpets, they could command a particular expressive power, but that power waned when trumpets were put to other uses." 
incomodava-se escrevendo que aquilo era anti-natural, tanto para o intérprete como para o instrumento. (DOLAN, 2013, p. 165, tradução nossa) $)^{292}$

O uso errôneo dos instrumentos seria, então, realizado pelos maus compositores:

Em 1805, C. F. Michaelis publicou (...) "Einige Bermerkungen über den Missbrauch der Blasinstrumente in der neuern Musik." A música tem muitas ferramentas em seu conjunto expressivo, dos quais o mais recente é o "uso aperfeiçoado dos instrumentos de sopro", que oferece - de acordo com Michaelis - "uma nova fonte de beleza e sublimidade". Haydn e Mozart popularizaram o uso dos instrumentos de sopro, mas eles também seduziram imitadores que usaram esses instrumentos "com desperdício e com frequência de forma completamente inapropriada". O que estava sendo desperdiçado, argumentou Michaelis, era o caráter dos instrumentos: "A flauta, o trompete, o fagote, o trombone, etc: cada um desses instrumentos é mais adequado que outro para sua própria expressão de diferentes emoções, para seu próprio modo de excitar a fantasia. Um é mais adequado a lamentos gentis, o outro mais capaz de expressar melancolia profunda, seriedade sombria. Um é mais bem indicado a efusões leves e alegres [Schwärmerei], o outro mais à ternura e ao conforto familiar; um é mais adequado à gentileza e indulgência femininas, outro mais capaz de expressar força masculina, coragem, e desafio. (DOLAN, 2013, p. 154, tradução nossa) ${ }^{293}$

292 “In 1798, Carl Zelter published an essay in the Allgemeine musikalische Zeitung entitled 'Bescheidene Anfragen an die modernsten Komponistenund Virtuosen'. Each question took up different forms of instrumental abuse: in the first, on the flute, Zelter recalled that there was 'a time when the flute not only was called but indeed was the sweetest of instruments, when it was the model and ideal to which all that was sweet-sounding was compared. Now it is otherwise. Modern composers usually write for the instrument so that it must shriek'. In the second of his 'modest questions', he asked, 'Why do most of the modern composers write for the horn, clearly against its nature and intrinsic beauty, like the trumpet, and for the trumpets, not seldom and also against their nature, like the horns?' Zelter was disturbed by writing that was unnatural, both for the performer and for the instrument."

293 "In 1805, C. F. Michaelis published (...) 'Einige Bemerkungen über den Missbrauch der Blasinstrumentein der neuern Musik.' Music has many tools in its expressive arsenal, the most recent of which is the 'perfected use of wind instruments', which offers - according to Michaelis - 'a new source of beauty and sublimity.' Haydn and Mozart popularized the use of the wind instruments, but they also seduced imitators who used these instruments 'wastefully and often completely inappropriately'. What was being wasted, Michaelis argued, was the character of the instruments: 'The flute, the trumpet, the bassoon, the trombone, etc.: each of these instruments is more suitable than another for its own expression of different emotions, for its own way of exciting the fantasy. One is more suitable for gentle complaints, the other better able to express deep melancholy, gloomy seriousness. One is better suited to cheerful and light effusions [Schwärmerei], the other more to tenderness and the comfort of the familiar; one is more suitable for feminine gentleness and indulgence, another better able to express masculine strength, courage, and defiance." 
A importância do caráter dos instrumentos fica mais do que explícita no texto de Michaelis e a maneira natural através da qual se comportariam a partir do bom uso dessas suas características traria benefícios expressivos à composição. Dolan continua:

\begin{abstract}
Michaelis [assim como Zelter] escreveu: "Aproximadamente todos os instrumentos de sopro já possuem em seu som e seu alcance, sua própria esfera de sentimento e afeto; assim, pelo propósito da expressão musical, não se deveria nem exceder seus limites nem deixar os instrumentos de sopro arbitrariamente passar à frente [vortreten] um do outro ou em outros instrumentos." A liberdade instrumental não implicava que os instrumentos deveriam ser usados de qualquer maneira imaginável; pelo contrário, ela vinha com rigor composicional e responsabilidades rigorosas. Se trompetes sempre se comportassem como trompetes, trompas como trompas, e flautas como flautas, não havia necessidade de articular como eles deveriam funcionar ou quando eles deveriam ser usados. Portanto, a noção de caráter implica primeiramente que os instrumentos tenham internalizado suas funções originais, e em segundo, que eles começaram a mover-se além dessas funções. E se as trompas se comportassem como trompetes, elas ameaçavam tornarem-se elas mesmas sem sentido. (2013, p.165-166, tradução nossa) $)^{294}$
\end{abstract}

\author{
O tipo de discurso desses autores alemães, focado naquilo que envolvia \\ principalmente os instrumentos de sopro, não é fruto do acaso ou ocorre por \\ coincidência:
}

\footnotetext{
294 "Michaelis likewise wrote: 'Nearly every wind instrument has already in its tone and range, its own sphere of feeling and affect; therefore, for the purpose of musical expression, one should neither exceed these boundaries nor let the wind instruments arbitrarily step in front of [vortreten] each other or other instruments.' Instrumental freedom did not imply that the instruments should be used in any imaginable way; rather, it came with rigorous compositional responsibilities. If trumpets always behaved as trumpets, horns as horns, and flutes as flutes, there was no need to articulate how they should function or when they should be used. Thus the notion of character implies first that the instruments have internalized their original functions, and second, that they have begun to move beyond those functions. And if horns behaved as trumpets, they threatened to render themselves meaningless."
} 
facilmente (como em todo lugar onde a determinação demasiada cerca a imaginação)". (DOLAN, 2013, p. 617, tradução nossa)295

Portanto, para Michaelis, os instrumentos de sopro seriam dotados de caracteres tão fortes, diretos e originais, que explicariam seu uso voltado para representações muito específicas e "materiais", como ideias prontas ou alegorias tradicionais. Em demasia, sua utilização deveras centrada em especificidades impediria os ouvintes de vivenciarem a "abstração musical" possível através das cordas. De certa forma, os sopros seriam instrumentos que traziam informações extramusicais tão claras que acabariam por se tornar inflexíveis, em certo grau. Isso não seria considerado um defeito, pelo contrário, contanto que fossem utilizados da maneira correta.

As opiniões dos autores citados anteriormente, provenientes de uma época na qual a orquestra clássica estava consolidada (as opiniões de Michaelis foram publicadas já em 1805), são exemplos de que o uso alegórico dos instrumentos de sopro a partir de seus caracteres particulares não teria deixado de existir mesmo quando passaram a fazer parte do corpo estável da orquestra. Sua presença constante não haveria de separá-los de sua simbologia ou ainda anulá-la. Mozart e Haydn eram na época vistos como exemplos de compositores que utilizavam bem os sopros na orquestra e esse bom uso, abundantemente mostrado em suas obras, estaria diretamente relacionado às suas aplicações alegóricas. Assim, pode-se imaginar que, ainda que pudesse haver um caminho aberto para o uso dos sopros em direção a uma ausência de sentido extramusical, isso por enquanto não teria sido totalmente possível. A tradição alegórica de tanto tempo poderia ser antiga, mas ainda tinha sua força.

\footnotetext{
295 "Schubart, Zelter, and Michaelis all heard pained trumpets and shrieking flutes, but no contorted strings. The new discourse of character was focused almost exclusively on the wind instruments, an emphasis that reflects an inequality inherent to the orchestra: some instruments were more 'colorful' and 'characterful' than others. Michaelis explicitly separated wind and string instruments: winds had distinct characters, while the strings did not. He writes: 'The string instruments, the less they imitate the wind instruments, the more they are capable of giving us the true form of music, and therefore true aesthetic pleasure, of which we do not tire easily. The wind instruments, however, have too much charm in their tones, too much that excites and fills out. They mix more materiality into our pleasure, of which we grow more easily weary (as everywhere where over-determination fences in the imagination)'."
} 


\subsection{Berlioz e o caráter dos instrumentos musicais}

Hector Berlioz, hoje tido como um dos genitores da orquestração moderna, publicou pela primeira vez o seu Grand traité d'instrumentation et d'orchestration modernes em 1844. Nesse momento, a Europa havia passado por transformações extremamente significativas e tornara-se um lugar muito distinto em relação ao século anterior, política e culturalmente. Na música, as portas para o Romantismo já haviam sido abertas (aliás, a obra musical considerada o marco inicial do período romântico é a Symphonie Fantastique, do próprio Berlioz).

A orquestra clássica deixara de ser uma novidade já há algumas décadas e, de fato, o grupo orquestral transformara-se significativamente, tanto em relação às suas dimensões quanto à formação instrumental: os grupos tornaram-se maiores e sonoramente mais potentes e outros instrumentos passaram a fazer parte do efetivo constante do conjunto. Em suma, tinha-se o início da orquestra romântica.

O tratado de Berlioz não foi o primeiro documento a abordar o assunto da orquestração, sendo que escritos do tipo começam a surgir ainda no século XVIII. No entanto, tornou-se um dos principais, tendo servido de referência a muitos compositores e estudiosos do assunto desde sua publicação primeira até os dias atuais, quando adquire também um valor histórico. Vê-se que, à época de Berlioz, o estudo técnico da orquestração tomara as dimensões de uma importante área de conhecimento musical, cuja consolidação permitira sistematizações e padronizações em meio às quais era possível apontar-se erros e acertos e valer-se de exemplos das obras de compositores já então aclamados como grandes orquestradores.

Em meio às muitas diferenças da forma romântica de se pensar a orquestração quando comparada à maneira setecentista, é interessante perceber que Berlioz, um compositor que buscava uma forma moderna de se orquestrar, não deixa de lado os aspectos concernentes ao caráter intrínseco dos instrumentos musicais e de sua simbologia, muito pelo contrário. Na introdução do documento, Berlioz define o objetivo do tratado:

O propósito da presente obra é primeiro, portanto, mostrar a extensão e certos detalhes essenciais do mecanismo de cada instrumento, e então examinar a natureza do som, caráter particular e potencial expressivo de 
cada - uma parte do estudo até aqui grandemente negligenciada - e finalmente considerar os melhores caminhos conhecidos de agrupá-los efetivamente. Indo além disso, estaríamos pisando no domínio da inspiração, onde apenas o gênio pode fazer descobertas e onde apenas ao gênio é permitido caminhar. (MACDONALD, 2004, p. 6, tradução nossa) ${ }^{296}$

Apesar de expressar opiniões que denunciam claramente a visão de um homem do século XIX, no que se refere à questão do gênio sendo tido como superior e inexplicável, Berlioz deixa claro sua preocupação com aspectos de caráter dos instrumentos já existentes, como visto, muito tempo antes, sendo, portanto, um herdeiro dessas questões. Nota-se também a insatisfação do autor com a pouca importância dada a elas, ao dizer claramente que teriam sido até ali negligenciadas. Essa afirmação do compositor serve de reflexo tardio àquilo que foi dito nesta tese a respeito da pequena documentação existente no que concerne ao assunto: se a questão não tinha sido amplamente explorada nos documentos dos séculos XVII e XVIII, ela ainda não o era em meados do XIX.

Macdonald comenta a respeito da preocupação de Berlioz em relação a esse aspecto:

O estudo do caráter e potencial expressivo de um instrumento era realmente mais importante para Berlioz que sua extensão e limites técnicos, apesar de todo seu cuidado em tratar dessas questões da maneira mais clara possível. Informações práticas já podiam ser encontradas em outros tratados e em métodos separados disponíveis para cada instrumento, então havia uma especial urgência em transmitir seu entendimento pessoal de cor e timbre, exprimido na noção de continuidade da tradição de Gluck a Spontini, de Beethoven e Weber até seus dias. (MACDONALD, 2004, p. xviii, tradução nossa) ${ }^{297}$

\footnotetext{
296 "The purpose of the present work is first, therefore, to show the range and certain essential details of the mechanism of each instrument, and then to examine the nature of the tone, particular character and expressive potential of each - a branch of study hitherto greatly neglected - and finally to consider the best known ways of grouping them effectively. Beyond that we would be stepping into the domain of inspiration, where only genius may make discoveries and where only genius is allowed to tread."

297 "The study of an instrument's character and expressive potential was really more important to Berlioz than its range and technical limits, careful though he was to set out the latter in as clear a manner as possible. Practical information was already to be found in other treatises and in the separate 'Méthodes' available for every instrument, so there was a special urgency in conveying his personal understanding of colour and timbre, couched in the notion of continuity and tradition from Gluck through Spontini,Beethoven and Weber to the present day."
} 
É preciso dizer que Berlioz fala de instrumentos diferentes daqueles do século XVIII, já que grande parte deles passava por mudanças na sua construção a fim de melhor se adaptar às necessidades musicais do período. Além disso, o compositor mostra muito de sua opinião pessoal a respeito deles, o que não significa que todos os músicos da época pensassem exatamente da mesma forma. De qualquer modo, no entanto, Berlioz dá muita importância ao caráter dos instrumentos bem como a suas potencialidades expressivas individuais e únicas. O modo como Berlioz entende o uso dos instrumentos a partir de seu caráter é também distinto da maneira do século XVIII: no período governado pela retórica, o caráter do instrumento e sua utilização em uma composição era visto como um importante complemento do discurso, como uma espécie de ingrediente especial que trazia maior sabor a uma obra, potencializando seu efeito. O caráter da obra estaria presente na composição em si, à qual um instrumento somaria sua expressividade como um adendo significativo. Já para Berlioz, o uso do instrumento e seu caráter seria não um complemento do discurso musical, mas sim um pilar de sua construção, sendo que o caráter da própria obra era definido pelos instrumentos usados em sua execução. Essa forma diferente de se contemplar o uso dos mesmos vem à tona em seus escritos.

Com sua linguagem romântica característica, em seu Tratado Berlioz dedica-se a explicar o caráter dos instrumentos de forma rica e expressiva, citando seu uso efetivo em diversos exemplos extraídos de obras de diferentes compositores. Eis alguns comentários referentes aos sopros de madeira:

O oboé é sobretudo um instrumento melódico; ele tem um caráter rústico, cheio de ternura, mesmo de timidez. (...) As características especiais do oboé transmitem candura, graça inocente, deleite sentimental ou o sofrimento das criaturas mais fracas. Ele expressa isso maravilhosamente bem em cantabile (...)

O caráter das notas agudas [do fagote] é penoso e doloroso, eu diria até mesmo miserável, e pode algumas vezes ser usado para o mais surpreendente efeito em uma melodia lenta ou figura de acompanhamento (...)

O caráter do registro intermediário da clarineta, marcado por um certo orgulho com sugestões de ternura e nobreza, a equipa bem para a expressão dos mais poéticos pensamentos e sentimentos. Apenas a frivolidade - e talvez também a alegria inocente - não parece adequar-se a ele. A clarineta não é feita para o idílico, ela é um instrumento para o épico, como as trompas, trompetes e trombones. Sua voz é a voz do amor heroico, e se o grupo de metais em grandes bandas militares traz à mente um regimento em armaduras brilhantes marchando para a glória ou para a 
derrota, um grupo de clarinetas em uníssono tocando com eles parece evocar os entes amados, esposas e enamorados, cujos olhos orgulhosos e sinceras paixões exultam ao som dos brasões, que cantam enquanto entram em combate e que coroam seus heróis conquistadores ou perecem com os derrotados (...)

A flauta de fato parece ser um instrumento quase que sem expressão; devido à sua facilidade em tocar notas rápidas e em sustentar notas agudas que uma orquestra precisa para preencher as partes superiores da harmonia, ela é constantemente chamada em todo tipo de circunstância. Em geral isso é verdadeiro. Mas se você estuda-la com cuidado reconhecerá sua expressão característica e compreenderá sua capacidade de proporcionar certos estados da mente de uma forma como nenhum outro instrumento consegue. Se por exemplo você precisa de um som desolado mas também humilde e resignado - as notas fracas do registro médio da flauta, especialmente nas tonalidades de dó e ré menor, certamente produzirão a nuance correta. (MACDONALD, 2004, pp. 103, 104, 113, 114, 125,140 , tradução nossa) ${ }^{298}$

Nota-se que, para todas as opiniões de Berlioz citadas anteriormente, é possível traçar uma linha de conexão com as ideias de caráter dos mesmos instrumentos existentes ao longo do século XVIII. A figura de Berlioz como um herdeiro dessa tradição fica então evidenciada, sugerindo que mesmo que o compositor mostrasse muito de sua opinião pessoal a respeito da questão, ele teria, dentro de toda sua modernidade romântica, de certo modo continuado aspectos tradicionais.

É interessante observar como Berlioz comenta com muita convicção a respeito de acertos e erros de grandes compositores em sua escolha do uso de determinado instrumento para a expressão de algum caráter ou situação:

\footnotetext{
298 "The oboe is above all a melodic instrument; it has a rustic character, full of tenderness, of bashfulness even. (...) The oboe's special characteristics convey candour, naive grace, sentimental delight, or the suffering of weaker creatures. It expresses this marvellously well in cantabile (...) The character of its top notes is rather painful and dolorous, I might even say miserable, which can sometimes be put to most surprising effect either in a slow melody or in an accompaniment figure (...) The character of the clarinet's intermediate register, marked by a certain haughtiness with intimations of tenderness and nobility, equips it well for the expression of the most poetic thoughts and feelings. Only frivolity - and perhaps naive joy too - seems to suit it not at all. The clarinet is not made for the idyllic, it is an instrument of the epic, like horns, trumpets and trombones. Its voice is the voice of heroic love, and if the massed brass in large military bands bring to mind a regiment in shining armour marching to glory or to death, massed clarinets in unison playing with them seem to evoke the loved ones, wives and sweethearts, whose proud eyes and earnest passions exult to the sound of arms, who sing as they enter the fray and who crown their conquering heroes or die with the defeated (...)

The flute in fact seems to be an instrument almost lacking in expression; because of its facility in playing rapid notes and in sustaining high notes which an orchestra needs to fill in the upper parts of the harmony, it is constantly called upon in every kind of circumstance. In general this is true. But if you study it carefully you will recognise its characteristic expression and grasp its capacity to render certain states of mind in a way no other instrument can. If for example you need a desolate - but also humble and resigned - tone for a sad melody, the weak notes in the flute's middle register, especially in the keys of C minor or D minor, will certainly produce the right nuance."
} 
[O oboé] tem a capacidade de expressar agitação a certo grau, mas se deve ser cuidadoso para não força-lo tão longe como a gritos de paixão ou balbucios de raiva ou ameaças ou heroísmo, de modo que sua pequena voz amarga se torne deveras ineficaz e absurda. Alguns grandes compositores, incluindo Mozart, cometeram esse erro. Suas partituras contêm passagens das quais o caráter apaixonado e marcial contrasta estranhamente com o som dos oboés que os tocam, e o resultado é não apenas um efeito mal julgado mas também uma má aliança chocante entre palco e orquestra e entre melodia e instrumentação. Uma melodia de marcha, por mais direta, bela e nobre, perde sua nobilidade, sua franqueza e sua beleza quando dada aos oboés. Ela perderia um pouco menos se dada às flautas e perderia quase nada se tocada por clarinetas. Se é absolutamente inevitável usar oboés em uma peça como eu descrevi, para dar mais corpo à seção de sopros ou mais força ao grupo de sopros já tocando, elas devem ao menos ser escritas de forma que seu timbre, que fica em desacordo com esse tipo de estilo, seja completamente coberto pelos outros instrumentos e indistinguível no conjunto. (MACDONALD, 2004, p.104, tradução nossa) ${ }^{299}$

Já mencionando aquilo que considera o bom uso do oboé em algumas obras de Gluck, Berlioz comenta:

Todas essas são sublimes, não apenas pela concepção dramática, profundidade de expressão, ou grandeza e beleza da melodia, mas também pela instrumentação e pela infalível escolha do compositor pelos oboés em meio a um rol de outros instrumentos incapazes de produzir tais efeitos. (MACDONALD, 2004, p. 104, tradução nossa) ${ }^{300}$

Essas e diversas outras opiniões de Berlioz presentes ao longo de todo o seu tratado mostram a preocupação do músico em relação à escolha do instrumento

\footnotetext{
299 "It has the capacity to express agitation to a certain degree, but one should be careful not to stretch it as far as cries of passion or the splutter of rage or threats or heroics, since its little bittersweet voice becomes quite ineffective and absurd. Some great composers, including Mozart, have made this mistake. Their scores contain passages whose passionate and martial character contrasts strangely with the sound of the oboes that play them, and the result is not just a misjudged effect but a shocking misalliance between stage and orchestra and between melody and instrumentation. A march melody, however direct, however beautiful, however noble, loses its nobility, its directness and its beauty when given to the oboes. It would lose a little less if given to the flutes and would lose almost nothing if played by clarinets. If it is absolutely unavoidable to use oboes in such a piece as I have described, to give more body to the wind section and more strength to the group of wind instruments already playing, they must at least be written for in such a way that their timbre, which is at odds with this kind of style, is completely covered by that of other instruments and is indistinguishable in the ensemble."

300 "All these are sublime, not just for the dramatic conception, the profundity of expression or the grandeur and beauty of the melody, but also for the instrumentation and for the composer's unerring choice of the oboes from among a crowd of other instruments quite incapable of producing such effects."
} 
musical correto, essencial à própria concepção de uma obra e sem a qual o caráter musical e, consequentemente, o sentido da composição, se perderia.

Berlioz não seria um dos compositores cuja música estaria buscando o caminho para um "absolutismo sonoro" sem referências externas, uma vez que a maioria de suas obras mais conhecidas e executadas até hoje são fortemente concebidas a partir de inspirações extramusicais. Sendo assim, não parece errôneo imaginar que o compositor certamente esteve cercado por simbolismos e representações herdadas de épocas anteriores (vistas a partir de suas opiniões e também através de sua admiração por compositores inseridos na tradição do uso alegórico dos instrumentos, como o citado Gluck), que permeavam sua obra, aos quais somava-se sua grande imaginação musical que resultava em efeitos orquestrais surpreendentes. Desse modo, ele teria, de forma eficaz, unido a tradição à inovação. 


\section{CONCLUSÕES}

O século XVIII deixou diversas evidências de continuação da antiga tradição de associações dos instrumentos a aspectos extramusicais que seguiram contribuindo para o modo a partir do qual os mesmos eram utilizados na música da época.

Em relação aos instrumentos de sopro, o setecento mantém essa tradição simbólica seguindo muito de perto aspectos já presentes no século XVII, período no qual os instrumentos ganham sua forma barroca e começam a ser utilizados nos grupos orquestrais e na música séria, frequentemente de forma alegórica. Tratados do período evidenciam o bom uso dos instrumentos de sopro a partir de características únicas encontradas em cada um deles, que auxiliam na formação de sua "personalidade" específica, de seu caráter, e o repertório da época mostra que esse caráter era musicalmente aplicado a fim de potencializar o discurso dos compositores.

Durante o século XVIII, antes da consolidação da orquestra clássica e de sua formação instrumental fixa, os instrumentos de sopro são frequentemente utilizados como efeitos especiais, fazendo aparições pontuais nas composições, nas quais sua "personalidade" funciona como importante ferramenta de transmissão de afetos e outras possíveis mensagens que pretendam ser levadas ao publico através da música, uma relevante soma às pretensões retóricas de uma obra. Na orquestra clássica, entretanto, mesmo com sua presença constante e tornada, de certa forma, "comum", os sopros continuam a mostrar suas forças simbólicas.

A associação dos sopros de madeira ao pastoral é antiquíssima e continua forte no século XVIII, sendo que inevitavelmente todos parecem conectar-se a esse aspecto em algum momento. Assim, representações envolvendo a vida e o amor pastoril, a simplicidade rústica ou delicada, a natureza, os cantos dos pássaros, as festas e danças campestres, etc, são frequentes no repertório desses instrumentos durante todo o período. Não obstante, cada um apresenta também significações muito próprias e complexas que os diferenciam entre si e enriquecem a música na qual são utilizados.

A preocupação dos compositores da época em relação à escolha da instrumentação de suas obras graças às possibilidades alegóricas dos instrumentos é evidente e isso dá forças à ideia de que os aspectos simbólicos envolvendo-os seriam assim conhecidos, assimilados e desfrutados por seu público. Naquela sociedade e 
momento histórico, essa tradição de concepção e uso estaria, desse modo, viva e em plena atuação.

O passar do tempo e as transformações sociais envolvendo o mundo das artes contribui para mudanças de pensamento que terminam por alterar significados, importâncias e objetivos artísticos de época para época. Algo extremamente evidente, efetivo, relevante ou necessário em determinado período pode tornar-se desinteressante, artificial e obsoleto anos depois. A arte é a expressão de um momento histórico e de suas concepções e emoções. O ser-humano se modifica e, logo, modifica-se a arte. Graças a essas modificações, vê-se ao longo da história a criação de novas formas de expressão, juntamente com a manutenção de outras, bem como o desaparecimento de algumas. Sendo assim, em relação à expressão musical, teria o simbolismo envolvendo os instrumentos e seu uso através desse viés continuado a existir após meados do século XIX?

Por um lado, todas as gerações de compositores influenciados pelo Traité de Berlioz certamente estaria a par desse uso e consequentemente não teria para ele virado as costas. Por outro lado, aqueles que defendessem a criação de uma música "absoluta" iriam abominá-lo. De qualquer modo, a criação e manutenção de gêneros instrumentais como o poema sinfônico, um dos emblemas da música oitocentista que adentram fortes o século $\mathrm{XX}$, poderiam ser vistos como meios de continuação da música representativa e mimética, dentro da qual a simbologia dos instrumentos continua a prosperar.

Mesmo na atualidade, em meio aos diversos universos artísticos nos quais os instrumentos musicais podem ser utilizados, ainda é possível encontrar interessantes exemplos modernos de seu tradicional uso alegórico: de uma forma ou de outra, os sopros de metal continuam a ser usados para representar a força heroica, o poder monárquico, o épico; as madeiras ainda conectam-se fortemente à natureza e à delicadeza, entre diversos outros aspectos. Os exemplos são muitos. A efetividade com a qual esse uso atinge o público, inclusive aquele musicalmente leigo, é evidente. De alguma forma, os instrumentos musicais e seus potenciais alegóricos, por mais que tenham se transformado, falam ainda muito diretamente a seus ouvintes 


\section{REFERÊNCIAS BIBLIOGRÁFICAS}

AGUIAR E SILVA, V. M. A poética da alegoria e o barroco. In: ANACLETO, M.T; AUGUSTO, S.; SANTOS, Z. D. Francisco Manuel de Melo e o barroco peninsular. Coimbra: Imprensa da Universidade de Coimbra, p.95-117, 2010.

AGUILAR, P. M. A flauta doce no Brasil - da chegada dos jesuítas à década de 1970. 2017. 258p. Tese (Doutorado em Musicologia) - Escola de Comuniações e Artes, Universidade de São Paulo, São Paulo, 2017.

ALTA. In: BROWN, H. M.; POLK, K. Grove Music Online. New York: Oxford University Press, 2001.2 Disponível em <http://www.oxfordmusiconline.com/grovemusic/view/10.1093/gmo/9781561592630 .001.0001/omo-9781561592630-e-0000000676?rskey=uZhsQg\&result=2>. Acesso em: 14 fev. 2019.

ANCELET. Observations sur la musique, les musiciens, et les instrumens. Amsterdam: Aux dépens de la Compagnie, 1757.

ARISTÓTELES. A Política. 2. ed. São Paulo: Martins Fontes, 1998.

BAINES, A. Woodwind Instruments and Their History. 3.ed. Mineola, New York: Dover Publications, INC., 1991.

. Fifteenth-Century Instruments in Tinctoris's De Inventione et Usu Musicae.

The Galpin Society Journal, v.3, p.19-26, 1950.

BEATTIE, J. Essais: on poetry and music, as they affect the mind. Edinburgh: William Creech, 1778.

BÉTHIZY, J-L de. Exposition de la théorie et de la pratique de la musique, suivant les nouvelles découvertes. Paris: Michel Lambert, 1764.

BLADES, J. Percussion Instruments and their History. London: Faber and Faber Limited, 1970.

BLAINVILLE, C. H. de. L'esprit de l'art musical, ou Reflexions sur la musique et ses différentes parties. Genêve, 1754.

BOLLIOUD de MERMET, L. De la Corruption du goust dans la musique françoise. Lyon: A. Delaroche, 1746.

BOWLES, E. A. The Role of Musical Instruments in the Medieval Sacred Drama. The Musical Quarterly, v.45, n. 1, p.67-84, 1959. 
BRAUN, L. T. The mistery of the chalumeau and its historical significance as revealed through selected works for chalumeau and early clarinet by Antonio Vivaldi, a lecture. 2016. 52p. Doctor of Musical Arts Dissertation - University of North Texas, Denton, 2016.

BROSSARD, S. de. Dictionaire de musique. Paris: Christophe Ballard, 1703.

CEIA, C. Sobre o conceito de alegoria. Matraga, v.10, p.19-26, 1998.

CERQUEIRA, F. V. Apolo e Mársias: certame ou duelo musical? Abordagem mitológica da dualidade simbólica entre a lira e o aulos. Classica. Revista brasileira de estudos clássicos. Belo Horizonte: v.25, n. 1/2, p. 61-78, 2012.

CHAFE, E. Analysing Bach Cantatas. New York: Oxford University Press, 2000.

CITTERN. In: TYLER, J. Grove Music Online. New York: Oxford University Press, 2001. Disponível em: <http://www.oxfordmusiconline.com/grovemusic/view/10.1093/gmo/9781561592630 .001.0001/omo-9781561592630-e-0000005831? rskey=9yedhE\&result=4>. Acesso em: 14 fev. 2019.

CONSORT. In: EDWARDS, W. Grove Music Online. New York: Oxford University Press, $2001 . \quad$ Disponível em <http://www.oxfordmusiconline.com/grovemusic/view/10.1093/gmo/9781561592630 .001.0001/omo-9781561592630-e-0000006322 ?rskey=CU97t6\&result=1>. Acesso em 14 fev. 2019.

CORRETTE, M. Méthode raisonnée pour apprendre aisément à jouër de la Flûtte Traversiere. Paris, ca. 1740.

COUPERIN, F. Troisième livre de pièces de clavecin. Paris: Chez L'Auteur, Boivin, 1722.

CRAWFORD, E. The Chalumeau in Eighteenth-Century Vienna: Works for Soprano and Soprano Chalumeau. 2008. 74p. Doctor of Music Treatise - College of Music, Florida State University, Tallahasee, 2008.

D'ALEMBERT, J. Fragments sur la musique en general et sur la notre en particulier. In: Oeuvre et correspondences inédites de d'Alembert publiées avec introduction, notes et appendices par Monsier Charles Henri. Paris: Perrin, 1887. p. 164-189.

DOLAN, E. I. The Orchestral Revolution: Haydn and the Technologies of Timbre. New York: Cambridge University Press, 2013.

DREYFUS, L. Bach's Continuo Group. Cambridge, Massachusetts and London: Harvard University Press, 1987.

DUBOIS, T. A. Christian Friedrich Daniel Schubart's "Ideen zu einer Aesthetik der Tonkunst": An annotated translation. 1983. 523p. Doctor of Philosophy (Musicology) 
Dissertation - Faculty of the Graduate School, University of Southern California, Los Angeles, 1983.

DURON, J. L'Orchestre de Marc-Antoine Charpentier. Revue de Musicologie, v. 72, n. 1, p. 23-65, 1986.

DÜRR, A. As cantatas de Bach. Bauru: Edusc, 2014.

E.H. Music \& Letters, Oxford, v. 43, n. 1, p. 74-76, 1962.

GARSAULT, F. A. P. de. Notionaire. Paris: Guillaume Desprez, 1761.

GHIRARDINI, C. Filippo Bonanni's Gabinetto armonico and the Antiquarian's Writings on Musical Instruments. Music in Art, v.33, n.1/2, p.168-234, 2008.

GRÉTRY, A. E. M. Mémoires, ou essai sur la musique. Paris: Chez l'auteur, 1789.

GRIECO, A. Livros de Emblemas: pequeno roteiro de Alciati à Iconologia de Cesare Ripa. Alceu, v.3, n.6, p.79-92, 2003.

GRISCOM, R. The recorder: a research and information guide. 3.ed. New York: Routledge, 2012.

HANSEN, J. A. Alegoria - construção e interpretação da metáfora. Campinas e São Paulo: Hedra e Editora da Unicamp, 2006.

HAYNES, B. The Eloquent Oboe: A History of the Hautboy from 1640 to 1760. New York: Oxford University Press, 2001.

HOEPRICH, E. The Clarinet. New Haven and London: Yale University Press, 2008.

HOLANDA, A. B. Dicionário Aurélio Básico da Língua Portuguesa. Rio de Janeiro: Nova Fronteira S/A, 1995.

HOLMAN, P. Purcell's Orchestra. The Musical Times, v. 137, n. 1835, 1996.

HOTTETERRE, J. Principes de la Flute Traversiere, ou flute d'Allemagne, de la Flute a Bec, ou flute douce, et du Haut-bois. Paris: Christophe Ballard, 1707.

INSTUMENS. In: DIDEROT, D. Encyclopedie ou Dictionnaire Raisonné des Sciences, des Arts et des Métiers: Tome Huitième. Neufchastel: Samuel Faulche, 1765.

KARP, C. The Early History of the Clarinet and Chalumeau. Early Music, v. 14, n. 4, p. 545-551, 1986.

KAUFFMANN, D. Violons en basse as Musical Allegory. The Journal of Musicology, v. 23, n. 1, p. 153-185, 2006. 
KOPP, J. B. The Bassoon. New Haven and London: Yale University Press, 2012.

LA BARRE, M. de. Pièces pour la Flute Traversière, avec la basse-continue. Paris: Christophe Ballard, 1702.

LA BORDE, J-B. de. Essai sur la musique ancienne et moderne. Paris: Ph.D. Pierres, 1780.

LANGWILL, L. G. The Bassoon and Contrabassoon. Third impression. London: Ernst Benn Limited, 1975.

LASOCKI, D. Die Blockflöte als Symbol der Liebe. ERTA Österreich News, v. 4, n. 2, 1998.

The flute in Handel's vocal works. Traverso, v. 14, n. 2, p. 5-7, 2002.

LAWSON, C. The Chalumeau: Independent Voice or Poor Relation? Early Music, v. 7, n. 3, p. 351-354, 1979.

LAWSON, C.; RICE, A. The Clarinet and Chalumeau Revisited. Early Music, v. 14, n. 4, p. 552-555, 1986.

LEOPOLD, S. The Orchestra in Early Opera. The Musical Quarterly, v.80, n.2, p.265-268, 1996. Lincoln: University of Nebraska Press, 1997.

LE Triomphe de l'Amour: Ballet, dancé devant sa Majesté a S. Germain en Laye le jour de Janvier 1681. Paris: Christophe Ballard, 1681.

MACDONALD, H. Berlioz's Orchestration Treatise: A Translation and Commentary. Cambridge: Cambridge University Press, 2004.

MARAIS, M. Pièces en trio. Paris: L'Autheur, 1692.

MATHIESEN, T. J. Apollo's Lyre: Greek music and music theory in antiquity and the middle ages. Lincoln and London: University of Nebraska Press, 1999.

MATTHESON, J. Das Neu-Eröffnete Orchestre. Hamburg: B. Schiller, 1713.

MCCREDIE, A. D. Instrumentarium and instrumentation in the north German baroque opera. 1964. 410p. Doktorwürde Dissertation - Philosophischen Fakultät, Universität Hamburg, Hamburg, 1963.

McGOWAN, K. The Prince and the Piper: Haut, Bas and the Whole Body in Early Modern Europe. Early Music, v. 27, n. 2, p. 211-216+218-220+222+224-232, 1999.

Mercure de France, dédié au Roi. Juin 1725. 1. Volume. Paris: Guillaume Cavelier, 1725. 
MOISÉS, M. Dicionário de termos literários. São Paulo: Cultrix, 2004.

ORO APOLLINE NILIACO. Delli segni hierogliphici, cioe Delle significationi di scolture sacre appresso gli Egittij. Tradotto in lingua uolgare per m. Pietro Vasolli da Fiuizano. Vinegia: Gabriel Ciolito de Ferrari, 1547.

PLATÃO. A República. São Paulo: Difusão Europeia do Livro, 1965.

POWELL, A. The Flute. New Haven and London: Yale University Press, 2002

PRAETORIUS, M. Syntagma Musicum II: De Organographia, Parts I and II. New York: Oxford University Press, 1986.

PROD'HOMME, J. G. Écrits des musiciens (XVe-XVIIle siècles). Paris: Mercure de France, 1912.

PROUT, E. Instrumentation. London: Novello and Company, Limited, 1902.

PURE, M. Idées des spectacles anciens et nouveaux. Paris: Michel Brunet, 1668.

QUINAULT, P. Le Triomphe de l'Amour. Paris: Christophe Ballard, 1681.

RAGUENET, F. Paralèle des Italiens et des François, en ce qui regarde la musique et les opéras. Paris: Jean Moreau, 1702.

RECORDER. In: LASOCKI, D. Grove Music Online. New York: Oxford University Press, $2001 . \quad$ Disponível em <https://www.oxfordmusiconline.com/grovemusic/view/10.1093/gmo/978156159263 0.001.0001/omo-9781561592630-e-0000023022?rskey=|4k21r> Acesso em 02 fev.2021.

RICE, A. R. The Baroque Clarinet. New York: Oxford University Press, 1992.

RIPA, C. Iconologia. Roma: Gio. Gigliotti, 1593.

. Della Novissima Iconologia. Padova: Pietro Paolo Tozzi, 1625.

. Iconologia. London: Benjamin Motte, 1709.

. Iconologia. Roma: Lepido Facÿ, 1603

. Iconologie. Paris: Jacques Villery, 1637.

ROUSSEAU, J-J. Dictionnaire de Musique. Paris: Chez la Veuve Duchesne, 1768.

Dictionnaire 
ROWLAND-JONES, A. Lully's Use of Recorder Symbolism. Early Music, v. 37, n. 2, p. 217-249, 2009.

SACHS, C. The history of musical instruments. New York: W.W. Norton \& Company Inc., 1940.

SADLER, G. Rameau and the Orchestra. Proceedings of the Royal Musical Association, v. 108 , p. $47-68,1981-82$.

SIMPSON, A. The orchestral recorder. In: THOMSON, J. M.; ROWLAND-JONES, A. The Cambridge Companion to the Recorder. New York: Cambridge University Press, 1995. cap. 5, p. 91-106.

SPITZER, J.; ZASLAW, N. The Birth of the Orchestra: History of an Institution, 16501815. New York: Oxford University Press, 2004.

STUBBS, S. L'armonia Sonora: Continuo Orchestration in Monteverdi's Orfeo. Early Music, v.22, n.1, p. 86-89+91-91+95-98, 1994.

TARASOV, N. Bach \& the Recorder. In: Windcanal. 2005? Disponível em <https://www.windkanal.de/bach-and-the-recorder-part-1>. Acesso em 02 fev. 2021.

TIBIA. In: ANDERSON, R.; McKINNON, J. Grove Music Online. New York: Oxford University $\quad$ Press, $2001 . \quad$ Disponível em <http://www.oxfordmusiconline.com/grovemusic/view/10.1093/gmo/9781561592630 .001.0001/omo-9781561592630-e-0000027930?rskey=D22v4l\&result=1>. Acesso em: 14 fev. 2019.

WEAVER, R. L. Sixteenth-Century Instrumentation. The Musical Quarterly, v.47, n. 3, pp. 363-378, 1961.

WEIGEL, J. C. Musikalisches Theatrum. Nüremberg: Johann Christoph Weigel, ca. 1722.

WINTERNITZ, E. Musical instruments and their symbolism in Western art: studies in music iconology. New Haven: Yale University Press, 1979.

ZIMMERMANN, H-J. English Translations and Adaptations of Cesare Ripa's Iconologia: From the 17th to the 19th Century. De zeventiende eeuw, v.11, n.1, p.17-25, 1995.

ZWILLING, C. O Livro do Cortesão de Baltassare Castiglione: tradução e comentários de passagens a respeito da música. São Paulo, 2016. 


\section{ANEXO}

- Tabela mostrando, resumidamente, as representações alegóricas mais comuns voltadas aos instrumentos de sopro de madeira ao longo do século XVIII. ${ }^{301}$

\begin{tabular}{|c|c|c|}
\hline $\begin{array}{l}\text { Instrumento de sopro de } \\
\text { madeira }\end{array}$ & $\begin{array}{l}\text { Representações } \\
\text { alegóricas recorrentes } \\
\text { durante o século XVIII }\end{array}$ & Observações \\
\hline Flauta doce & $\begin{array}{l}\text { - Pastoral } \\
\text { - Fúnebre (ou de alguma } \\
\text { forma associada à dor ou ao } \\
\text { extraterreno) } \\
\text { - Imitação de cantos de } \\
\text { pássaros (muito comum na } \\
\text { utilização das flautas mais } \\
\text { agudas e dos flageolets) } \\
\text { - Amor (e outras emoções } \\
\text { similares) }\end{array}$ & $\begin{array}{l}\text { - O instrumento foi utilizado } \\
\text { até meados do século, } \\
\text { praticamente caindo em } \\
\text { desuso após } 1750 \\
\text { - O Amor representado pela } \\
\text { flauta doce parece mais } \\
\text { conectado à inocência e à } \\
\text { simplicidade }\end{array}$ \\
\hline Flauta transversal & $\begin{array}{l}\text { - Amor, ternura, delicadeza e } \\
\text { charme, mas também, por } \\
\text { vezes, tristeza e languidez } \\
\text { - Pastoral } \\
\text { - Imitação de cantos de } \\
\text { pássaros }\end{array}$ & $\begin{array}{l}\text { - O Amor que a flauta } \\
\text { transversal representa é não } \\
\text { raro ligado ao infortúnio (à } \\
\text { perda ou não- } \\
\text { correspondência do amado e } \\
\text { outras "dores amorosas") } \\
\text { - Os cantos de pássaros por } \\
\text { ela representados têm, } \\
\text { normalmente, caráter suave } \\
\text { e melodioso (a associação } \\
\text { com o rouxinol é recorrente) } \\
\text { - Com o desuso da flauta } \\
\text { doce, a flauta transversal } \\
\text { toma algumas de suas } \\
\text { representações }\end{array}$ \\
\hline Oboé & $\begin{array}{l}\text { - Pastoral } \\
\text { - Versatilidade na } \\
\text { representação de grande } \\
\text { variedade de afetos e } \\
\text { emoções }\end{array}$ & $\begin{array}{l}\text { - O uso pastoral do oboé } \\
\text { comumente volta-se para o } \\
\text { alegre e o rústico } \\
\text { - Por seu tradicional e } \\
\text { recorrente uso junto aos } \\
\text { violinos, o oboé parece ter } \\
\text { seu papel de instrumento de } \\
\text { "efeito especial" reduzido } \\
\text { em comparação às outras } \\
\text { madeiras } \\
\text { - Sempre considerado } \\
\text { extremamente expressivo, } \\
\text { ele foi utilizado para } \\
\text { exprimir uma vasta gama de }\end{array}$ \\
\hline
\end{tabular}

${ }^{301}$ Algumas representações são comuns já no século XVII, ou ainda antes. 


\begin{tabular}{|c|c|c|}
\hline & & $\begin{array}{l}\text { sentimentos, não } \\
\text { apresentando o mesmo nível } \\
\text { de "especificidade } \\
\text { representativa" de outros } \\
\text { instrumentos de sopro }\end{array}$ \\
\hline Clarineta (e chalumeau) & $\begin{array}{l}\text { Clarineta: } \\
\text { - Pastoral } \\
\text { - Amor } \\
\text { Chalumeau: } \\
\text { - Amor, delicadeza, } \\
\text { intimidade, tristeza } \\
\text { - Pastoral }\end{array}$ & $\begin{array}{l}\text { - Durante a primeira metade } \\
\text { do século XVIII, a clarineta } \\
\text { foi usada principalmente por } \\
\text { seu registro agudo (que } \\
\text { poderia lembrar o som de } \\
\text { um trompete "à distância"), } \\
\text { comumente em imitação do } \\
\text { referido instrumento de } \\
\text { metal. O tipo de } \\
\text { representação pastoral à } \\
\text { qual o instrumento se } \\
\text { conecta nesse período } \\
\text { normalmente tem ligação } \\
\text { com o rústico, o rural ou } \\
\text { florestal e com a caça. } \\
\text { - Após } 1750 \text {, as novidades na } \\
\text { construção da clarineta } \\
\text { permitiram que seu registro } \\
\text { grave fosse melhor utilizado } \\
\text { e sua sonoridade se } \\
\text { tornasse, de certo modo, } \\
\text { mais suave e "aveludada". } \\
\text { Com isso, a clarineta passou } \\
\text { a executar o tipo de música } \\
\text { antes comum ao chalumeau, } \\
\text { tomando para si também } \\
\text { suas representações } \\
\text { alegóricas. Possivelmente, } \\
\text { isso teria contribuído para o } \\
\text { gradual desuso do } \\
\text { chalumeau do } \\
\text { - Na segunda metade do } \\
\text { século XVIII, a clarineta é } \\
\text { normalmente vista como um } \\
\text { instrumento "amoroso" }\end{array}$ \\
\hline Fagote & $\begin{array}{l}\text { - Pastoral (comumente como } \\
\text { baixo do oboé) } \\
\text { - Lúgubre, melancólico, } \\
\text { triste, sério, solene }\end{array}$ & $\begin{array}{l}\text { - Apesar da predominância } \\
\text { da representação voltada à } \\
\text { seriedade, durante o século } \\
\text { XVIII o instrumento é usado } \\
\text { de forma versátil, } \\
\text { aparecendo como detentor } \\
\text { de aspectos de caráter } \\
\text { oposto. A dualidade em suas } \\
\text { representações alegóricas } \\
\text { (por vezes ocorrendo graças } \\
\text { à diferença de seus registros }\end{array}$ \\
\hline
\end{tabular}




\begin{tabular}{|l|l|}
\hline & grave e agudo) é notável. \\
- O uso do fagote como \\
instrumento cômico ocorre \\
no século XVIII em obras de \\
compositores como Haydn e \\
Mozart. Porém, a alcunha de \\
"palhaço da orquestra" foi \\
Ihe dada apenas no XIX
\end{tabular}

